\title{
One-Pot Three-Component Vicinal Diamines Synthesis via In Situ Aminal Formation and Carboamination ${ }^{\star \star}$
}

\author{
Ugo Orcel and Jerome Waser ${ }^{*[a]}$
}

Dedication ((optional))

\begin{abstract}
A synthesis of vicinal diamines via in situ aminal formation and carboamination of allylamines is reported herein. Employing highly electron poor trifluoromethyl aldimines was key to enable both a fast and complete aminal formation as well as the palladiumcatalyzed carboamination step. The conditions developed allow the introduction of a wide variety of alkynyl, vinyl, aryl and hetereoaryl groups with complete regioselectivity and high diastereoselectivity. The reaction exhibits a high functional group tolerance. Importantly, either nitrogen atom of the imidazolidine products can be selectively deprotected, while removal of the aminal tether can be achieved in a single step under mild conditions to reveal the free diamine. We expect that this work will promote the further use of mixed aminal tethers in organic synthesis.
\end{abstract}

Vicinal diamines are of utmost importance in in natura products, agrochemicals, drugs and as chiral ligands. ${ }^{[1]}$ Hence, tremendous efforts have been invested to develop new methods to access them efficiently. ${ }^{[2]}$ Olefins have been widely used as simple and readily available substrates for the preparation of diamines ${ }^{[3]}$ The intermolecular diamination of alkenes through the formation of two new $\mathrm{C}-\mathrm{N}$ bonds for example is one of the most direct synthetic approaches. ${ }^{[2 h, 4]}$ However, this strategy is often limited in scope and leads usually to identically substituted nitrogen atoms, thus hampering their differentiation and further elaboration. Tethering both nitrogen atoms to the olefin has been a successful approach to meet this challenge. The diamine motif is then accessed either via intramolecular diamination, ${ }^{[5]}$ or through formation of one $\mathrm{C}-\mathrm{N}$ bond when starting from allylamine derivatives and forming a five-membered ring. ${ }^{[6]}$ The latter might be accompanied by the simultaneous formation of another bond onto the olefin. In particular, ureas and sulfamates have been widely used in both approaches due to their robustness. ${ }^{[5,6]}$ The use of palladium catalysis is particularly attractive, since it enables both the mono- and difunctionalization of olefins. ${ }^{[5 a, c, 6 e-k]}$ For example, Wolfe and co-workers described the use of classical sulfamide tethers for carboamination reactions (Scheme 1, A) ${ }^{[6 h, i]}$ However, the reaction requires strong tert-butoxide bases at elevated temperatures, and final cleavage of the sulfamide tether occurs in presence of $\mathrm{HBr}$ at $130^{\circ} \mathrm{C}$ for a prolonged period of time. Such harsh conditions are highly detrimental for the tolerance to functional groups and the scope of the reaction.

In this context, we were attracted by the use of aminals as $\mathrm{Csp}^{3}$ tethers, ${ }^{[7]}$ which have received much less attention than the classical urea and sulfamide tethers. They offer the precious advantage of being potentially more easily installed and removed, and could still engage efficiently in olefin functionalization

[*] Ugo Orcel and Prof. Dr. Jerome Waser Laboratory of Catalysis and Organic Synthesis Ecole Polytechnique Fédérale de Lausanne EPFL SB ISIC LCSO, BCH 4306, 1015 Lausanne, CH E-mail: jerome.waser@epfl.ch Homepage: http://lcso.epfl.ch/

Supporting information for this article is given via a link at the end of the document. processes. Furthermore, the obtained imidazolidine products provide a direct access to other highly important nitrogencontaining heterocycles such as imidazolines, imidazoles and $N$ heterocyclic carbenes. ${ }^{[8]}$ Among the scarce reports employing aminals as tethers, only two groups described the functionalization of non-activated olefins (Scheme 1, B and C). ${ }^{[9]}$ The seminal contribution of Hiemstra and coworkers describes the use of aminal tethers for Aza-Wacker cyclizations starting from allylic amines. However, tether installation and removal proved to be tedious, requiring five separate steps (Scheme 1, B). ${ }^{\text {9a] }}$ More recently, Beauchemin and coworkers reported a Cope-type hydroamination of simple allylamines in one step (Scheme 1, B) $\cdot^{\left[{ }^{9 b-f]}\right.}$ While elegant, both works remain limited to a single $\mathrm{C}-\mathrm{N}$ bond formation.

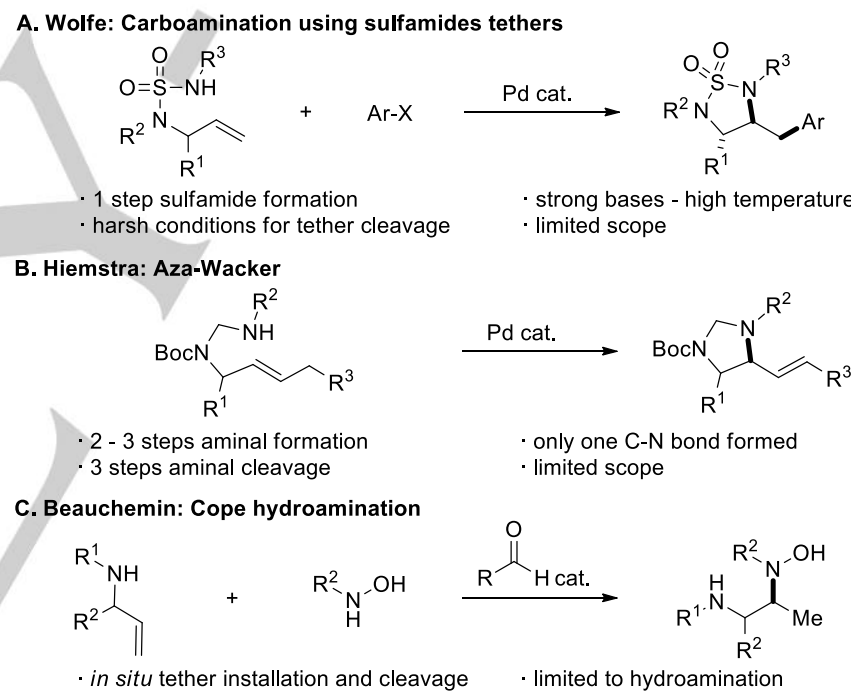

D. This work: 3-component aminal formation - carboamination

$$
\begin{aligned}
& \text { Scheme 1. Synthesis of diamines using a tether approach. } \\
& \text { - in situ aminal installation }
\end{aligned}
$$

Recently, our group has demonstrated that vicinal amino alcohols could be synthesized from allyl amines using an acetal tether and a palladium catalyst to form simultaneously one new $\mathrm{C}-\mathrm{O}$ and $\mathrm{C}-\mathrm{C}$ bond. ${ }^{[10 a]}$ We envisioned that an allylic amine and an imine could in situ form an aminal, which would undergo a Pdcatalyzed carboamination reaction to generate an imidazolidine via formation of both a C-N and a C-C bond (Scheme 1, D). ${ }^{[11]}$ All the reported mixed aminals employed for olefin functionalization bear electron-withdrawing groups on both nitrogen atoms, which greatly stabilize them. However, the poor nucleophilicity of the amine precursor prevents their fast synthesis. ${ }^{[7]}$ We thought to use nucleophilic allylamines to solve this issue. Three challenging conditions must be met to ensure the success of the envisioned transformation:

(i) formation of the aminal must be complete, fast and selective to avoid side reactions or catalyst deactivation, 
(ii) the mixed aminal formed needs to be both stable and suitable for the envisioned Pd-catalyzed carboamination, (iii) the imidazolidine obtained must be stable under the reaction conditions to avoid catalyst poisoning, but still be amenable to a straightforward deprotection to free the diamine.

The efficient implementation of this approach is reported herein, employing electron-rich allylamines, carbamate-protected trifluoroaldimines and a bromide, in presence of a commercially available palladium source and phosphine ligands. The developed conditions allowed for a broad scope in both allylamines and alkynyl, aryl or vinyl bromides, as well as for high stereo-, regio- and diastereoselectivity.

We started our studies with benzylallyl amine (1) and silyl acetylene $\mathbf{3}$ as efficient electrophilic partner in $\mathrm{Pd}^{0} / \mathrm{Pd}^{\prime \prime}$ catalyzed olefin functionalization (Table 1). ${ }^{[10,12]}$ We identified aldimine precursor $2 \mathrm{a}$ as efficient tethering reagent in combination with $\mathrm{Pd}_{2} \mathrm{dba}_{3}$ as palladium source, $\mathrm{P}(2 \text {-furyl })_{3}$ as ligand, and cesium carbonate as base. Under these conditions, imidazolidine 4 was isolated in excellent yield and diastereoselectivity $(95 \%, d r>$ $20: 1$ ) (entry 1). Importantly, $2 \mathbf{a}$ is easily available on multigram scale, ${ }^{[13]}$ bench stable for months, and only a slight excess is required to achieve complete conversion to 4 . As anticipated, the choice of the tether played a crucial role on the reaction outcome. Electron neutral aldimine $\mathbf{2 b}$

Table 1. Optimization of the tethered aminoalkynylation. ${ }^{[a]}$

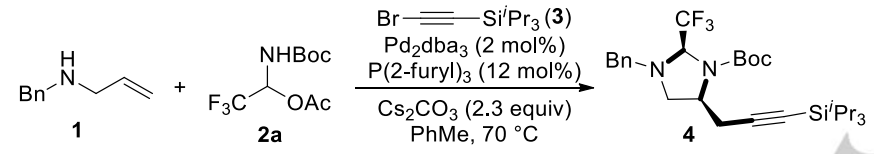

\begin{tabular}{|c|c|c|}
\hline Entry & Changes from standard conditions & Yield $(\%)^{[b]}$ \\
\hline 1 & none & $99(95)^{[c]}$ \\
\hline 2 & $\mathbf{2 b}$ instead of $\mathbf{2 a}$ & $<3$ \\
\hline 3 & $2 c$ instead of $2 a$ & 15 \\
\hline 4 & $\mathbf{2 d}$ instead of $\mathbf{2 a}$ & 36 \\
\hline 5 & $\mathbf{2 e}$ instead of $\mathbf{2 a}$ & 5 \\
\hline 6 & $2 \mathbf{f}$ instead of $\mathbf{2 a}$ & 35 \\
\hline 7 & $2 \mathrm{~g}$ instead of $2 a$ & 45 \\
\hline 8 & $2 \mathrm{~h}$ instead of $\mathbf{2 a}$ & 5 \\
\hline 9 & $\mathbf{2} \mathbf{i}$ instead of $\mathbf{2 a}$ & 7 \\
\hline 10 & $\mathrm{PPh}_{3}(12 \mathrm{~mol} \%)$ instead of $\mathrm{P}(2 \text {-furyl })_{3}$ & 39 \\
\hline 11 & PhDavePhos (11 mol\%) instead of $\mathrm{P}(2 \text {-furyl })_{3}$ & 81 \\
\hline 12 & DavePhos (11 mol\%) instead of $\mathrm{P}(2 \text {-furyl })_{3}$ & 11 \\
\hline 13 & BINAP $(6 \mathrm{~mol} \%)$ instead of $\mathrm{P}(2 \text {-furyl })_{3}$ & 3 \\
\hline 14 & DPEPhos $(6 \mathrm{~mol} \%)$ instead of $\mathrm{P}(2 \text {-furyl })_{3}$ & 90 \\
\hline 15 & XANTPhos $(6 \mathrm{~mol} \%)$ instead of $\mathrm{P}(2 \text {-furyl })_{3}$ & 58 \\
\hline 16 & $\mathrm{CsHCO}_{3}$ instead of $\mathrm{Cs}_{2} \mathrm{CO}_{3}$ & 44 \\
\hline 17 & $\mathrm{~K}_{2} \mathrm{CO}_{3}$ instead of $\mathrm{Cs}_{2} \mathrm{CO}_{3}$ & 89 \\
\hline 18 & Benzyl allylcarbamate instead of $\mathbf{1}$ & 8 \\
\hline 19 & without $\mathrm{Pd}_{2} \mathrm{dba}_{3}$ or $\mathrm{P}(2 \text {-furyl })_{3}$ or base & $<3$ \\
\hline
\end{tabular}

${ }^{[a]}$ Reactions conditions: $0.10 \mathrm{mmol} 1,0.11 \mathrm{mmol} 2 \mathrm{a}, 0.13 \mathrm{mmol} 3,0.33 \mathrm{M}$ in $\mathrm{PhMe}, 20 \mathrm{~h}$. ${ }^{[b]} \mathrm{NMR}$ yield using 3,4,5-trichloropyridine as internal standard

${ }^{[c]}$ Isolated yield on $0.30 \mathrm{mmol}$ scale.

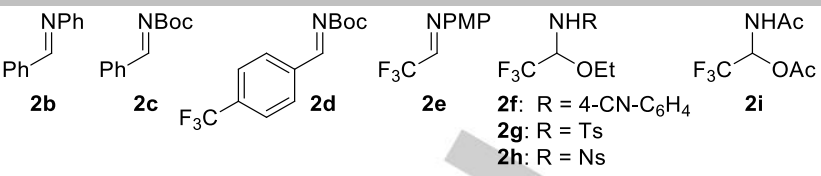

was ineffective (entry 2), while more activated $N$-Boc aryl imines still suffered from poor reactivity (entries 3-4). Various $N$ protected trifluoromethyl aldimines did provide some improvement, but furnished inferior results than 2a (entries 5-9). Changing the ligand had also a profound effect. Whereas using simple triphenylphosphine decreased the yield (entry 10), the bulky PhDavePhos afforded 4 in high yield (entry 11). The electron-rich DavePhos was not efficient (entry 12). Regarding bidentate phosphines, BINAP was not competent, DPEPhos yielded $90 \%$ of $\mathbf{4}$, and the closely related XANTPhos only $58 \%$ (entries 13-15). Switching to cesium hydrogen carbonate as base still afforded significant amount of $\mathbf{4}$, while potassium carbonate provided $89 \%$ of the desired imidazolidine (entries 16-17). The use of such mild bases is very rare for $\mathrm{Pd}^{0} / \mathrm{Pd}^{\prime \prime}$-catalyzed carboamination reactions, which often require stronger alkoxides. Deactivating the allylamine with a carbamate protecting group led to very low conversion (entry 18). Finally, without palladium or ligand or base, 4 was not observed (entry 19).

The scope of the reaction was then examined (Scheme 2). We performed an assessment of functional group tolerance and electronic effects by varying the substitution on the nitrogen atoms (Scheme 2, A). The use of a methyl carbamate protected tether also provided product $\mathbf{5}$ in excellent yield. Modifying the benzyl group with electron donating or withdrawing groups had only minor influence (products 5-10). Both the useful aryl bromide (product 8) and chloride (product 9) were preserved under these conditions. When performed on gram-scale, compound $\mathbf{1 0}$ was obtained in quantitative yield. A simple allyl group was also tolerated, with no Heck side reaction observed (product 11). Imidazolidines bearing a furan heterocycle or a ferrocene group were obtained in 92 and $89 \%$ yield respectively (products 12 and 13). The use of primary allylamines was also possible (product 14). Finally, replacing an aliphatic amine by an aniline still furnished the desired imidazolidine $\mathbf{1 5}$ in high yield.

Geminal substitution of the olefin was possible when using PhDavePhos as ligand (Scheme 2, B). a-Tertiary amine 16 and 17 were formed in good to high yields and with high diastereoselectivity $(\mathrm{dr}>20: 1)$.

Next, we investigated $\alpha$-substituted allylamines (Scheme 2, C). ${ }^{[14]}$ This class of substrates required the use of cesium triflate as additive to ensure high conversions. ${ }^{[15]}$ Substitution by a methyl group furnished the desired imidazolidines $\mathbf{1 8}$ in high yield, albeit in low diastereoselectivity. A bis-allylic amine delivered 19 in good yield and diastereoselectivity. Bicyclic and tricyclic imidazolidines 20, 21 and 22 were formed in high diastereoselectivity. These results highlight the fast access to complex structures with control on up to four stereocenters in a single step.

The scope of organohalides was then examined. Alkynes derived from secondary and tertiary propargylic alcohols underwent the desired transformation in good to excellent yields (Scheme 2, D, products 23-26). Notably, both aliphatic and aromatic substituents were tolerated at the propargylic position. We then turned our attention to aryl bromides (Schemes 2, E and F). This class of electrophiles could be used as long as they were slightly activated with an electron-withdrawing group. While DPEPhos was a competent ligand in certain cases, the $\begin{array}{lllll}\text { combination of } & \mathrm{P}(2 \text {-furyl })_{3} & \text { with } & \text { cesium }\end{array}$ 
Scheme 2. Scope of the tandem aminal formation carboamination reaction ${ }^{[a]}$

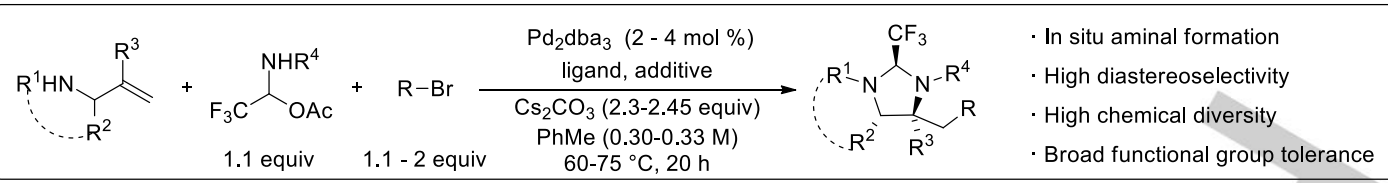

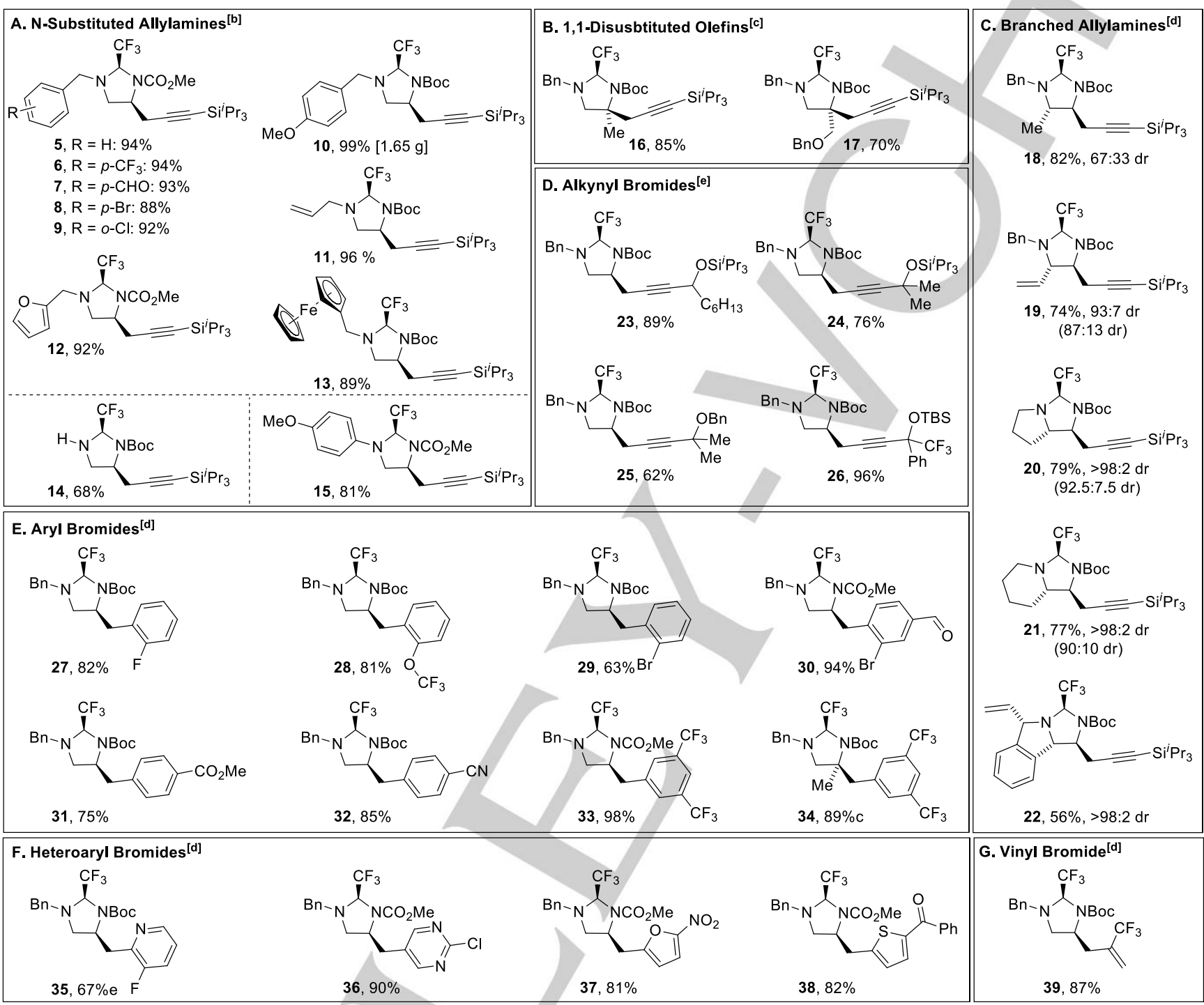

${ }^{[a]} d r>20: 1$ unless otherwise noted; $d r$ in parenthesis represents the diastereoisomeric ratio in the crude reaction mixture if different from the one of the isolated compound. ${ }^{[b]} \mathrm{P}(2-\mathrm{Furyl})_{3}(12 \mathrm{~mol} \%)$ was used as ligand. ${ }^{[\mathrm{c}]} \mathrm{PhDavePhos}(15-20 \mathrm{~mol} \%)$ was used as ligand. ${ }^{[\mathrm{d}]} \mathrm{P}(2-\mathrm{Furyl}){ }_{3}(24 \mathrm{~mol} \%)$ was used as ligand and cesium triflate as additive (1.2 equiv). ${ }^{[\mathrm{e}]}$ DPEPhos (12 mol\%) was used as ligand.

triflate as additive was more general and reliable. Ortho and para substitution were well tolerated (products 27-32). 1,2-Dibromo aryls underwent the reaction smoothly to afford brominated products 29 and 30, which open up possibilities for further derivatizations. Substitution at the meta positions cleanly delivered the desired products $\mathbf{3 3}$ and $\mathbf{3 4}$ bearing an $\alpha-$ secondary and an a-tertiary amine respectively. Due to the importance of aromatic heterocycles in the agrochemical and pharmaceutical industries, several heteroaryl bromides were then submitted to the reaction conditions (Scheme 2, F). Gratifyingly, both fluoropyridine and chloropyrimidine were introduced in good to excellent yields (products 35 and 36). Imidazolidines $\mathbf{3 7}$ and $\mathbf{3 8}$ bearing either a furan or a thiophene ring could be obtained in 81 and $82 \%$ yield respectively. Finally, aminoalkenylation was also possible (Scheme 2, G). Trifluoromethyl-substituted olefin 39 could be isolated in $87 \%$ yield.
To highlight the synthetic potential of the obtained building blocks, we synthesized either of the free amines selectively (Scheme 3). Starting from 10, oxidative cleavage of the paramethoxybenzyl (PMB) protecting group lead to free amine 14 in high yield, while heating under microwave irradiation cleanly removed the boc group to access $\mathbf{4 0}$ in nearly quantitative yield. TIPS removal with TBAF yielded terminal alkyne $\mathbf{4 1}$ in $98 \%$ yield. Finally, cleavage of the aminal was performed. Using $\mathrm{HCl}$ in methanol delivered diamine salt $\mathbf{4 2}$ in $89 \%$ yield. Treatment of imidazolidines $\mathbf{2 0}$ and $\mathbf{3 4}$ with trifluoroacetic acid followed by addition of methanol allowed full removal of the tether in excellent yields, without any further purification. The mild acidic conditions used are routinely applied in peptide chemistry. 


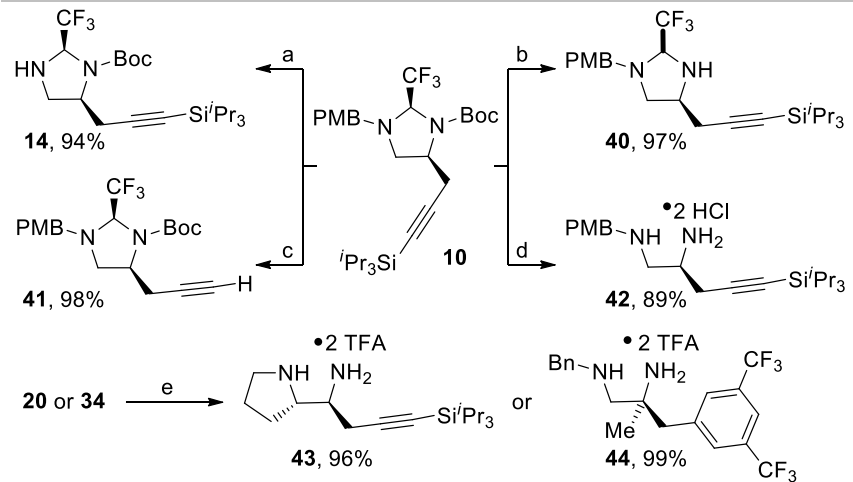

Scheme 3. Orthogonal deprotections. Reaction conditions: a) DDQ, MeCN $\mathrm{H}_{2} \mathrm{O}$, rt; b) microwave irradiation $\left(160{ }^{\circ} \mathrm{C}\right), \mathrm{H}_{2} \mathrm{O} /$ Ethanol; c) TBAF, THF, $0{ }^{\circ} \mathrm{C}$ to rt; d) $\mathrm{HCl}, \mathrm{MeOH},-40{ }^{\circ} \mathrm{C}$ to rt; e) TFA, $\mathrm{CH}_{2} \mathrm{Cl}_{2}$ then $\mathrm{MeOH}, 0{ }^{\circ} \mathrm{C}$ to rt.

In conclusion, we have developed the first palladiumcatalyzed carboamination of allylamines employing an in situ installed $\mathrm{Csp}^{3}$ aminal tether for the synthesis of 1,2-diamines. The use of carbamate-protected trifluoroaldimines allowed excellent regio- and diastereoselectivities under mild reactions conditions, a high functional-group tolerance and a broad scope. The versatility of our method was demonstrated by the introduction of alkynyl, aryl, heteroaryl and vinyl groups onto the allylamines. Both free amines could be obtained orthogonally, while complete tether cleavage to give diamines was performed under mild conditions. Based on our results, we expect that the use of aminal tethers will find much broader application in the future.

\section{Acknowledgements}

We thank EPFL and the Swiss National Science Foundation (grant number 200021_159920) for financial support.

Keywords: vicinal diamines, tether, aminal, Pd-catalysis, alkenes.

[1] For general reviews on 1,2-diamines, see: a) Y. L. Bennani, S Hanessian, Chem. Rev. 1997, 97, 3161; b) D. Lucet, T. Le Gall, C Mioskowski, Angew. Chem., Int. Ed. 1998, 37, 2580; c) A. Viso, R. F de la Pradilla, A. García, A. Flores, Chem. Rev. 2005, 105, 3167; d) J.C. Kizirian, Chem. Rev. 2008, 108, 140; e) S. R. S. S. Kotti, C Timmons, G. Li, Chem. Biol. Drug Des. 2006, 67, 101; f) O. O. Grygorenko, D. S. Radchenko, D. M. Volochnyuk, A. A. Tomalchev, I. V. Komarov, Chem. Rev. 2011, 111, 5506.

[2] For selected reports of diamine synthesis, see: a) A. Okada, T. Shibuguchi, T. Ohshima, H. Masu, K. Yamaguchi, M. Shibasaki, Angew. Chem., Int. Ed. 2005, 44, 4564; b) H. Du, W. Yuan, B. Zhao, Y. Shi, J. Am. Chem. Soc. 2007, 129, 7496; c) D. Uraguchi, K. Koshimoto, T. Ooi, T. J. Am. Chem. Soc. 2008, 130, 10878; d) S. Handa, V. Gnanadesikan, S. Matsunaga, M. Shibasaki, M. J. Am. Chem. Soc. 2010, 132, 4925; e) T. A. Davis, J. N. Johnston, Chem. Sci. 2011, 2, 1076; f) T. Kano, R. Sakamoto, M. Akakura, K. Maruoka, J. Am. Chem. Soc. 2012, 134, 7516; g) E. L. Ingalls, P. A. Sibbald, W. Kaminsky, F. E. Michael, J. Am. Chem. Soc. 2013, 135, 8854; h) D. E. Olson, J. Y. Su, D. A. Roberts, J. DuBois, J. J. Am. Chem. Soc. 2014, 136, 13506; i) E. Fava, A. Millet, M. Nakajima, S. Loescher, M. Rueping, Angew. Chem. Int. Ed. 2016, 55, 6776 .

[3] a) M. B. Gasc, A. Lattes, J. J. Perie, Tetrahedron 1983, 39, 703; b) S. D. Jong, D. G. Nosal, D. J. Wardrop, Tetrahedron 2012, 68, 4067.

[4] For recent reviews on alkene diamination, see: a) R. M. de Figueiredo, Angew. Chem., Int. Ed. 2009, 48, 1190; b) F. Cardona, A. Goti, Nat Chem. 2009, 1, 269;. c) K. Muñiz, C. Martínez, J. Org. Chem. 2013, 78 2168; d) Y. G. Zhu, R. G. Cornwall, H. F. Du, B. G. Zhao, Y. Shi, Acc Chem. Res. 2014, 47, 3665.
[5] Selected examples: a) J. Streuff, C. H. Hövelmann, M. Nieger, K. Muñiz, J. Am. Chem. Soc. 2005, 127, 14586; b) K. Muñiz, J. Streuff, C. H. Hövelmann, A. Núñez, Angew. Chem. Int. Ed. 2007, 46, 7125; c) K. Muñiz, C. H. Hövelmann, J. Streuff, J. Am. Chem. Soc. 2008, 130, 763; d) P. Chavez, J. Kirsch, C. H. Hovelmann, J. Streuff, M. MartinezBelmonte, E. C. Escudero-Adan, E. Martin, K. Muñiz, Chem. Sci. 2012, 3, 2375.

[6] Selected examples: a) P. A. Hunt, C. May, C. J. Moody, Tetrahedron Lett. 1988, 29, 3001; b) F. C. Sequeira, B. W. Turnpenny, S. R. Chemler, Angew. Chem., Int. Ed. 2010, 49, 6365; c) G. Zhang, Y. Luo, Y. Wang, L. Zhang, Angew. Chem., Int. Ed. 2011, 50, 4450; d) L. Zhu P. Xiong, Z.-Y. Mao, Y.-H. Wang, X. Yan, X. Lu, H.-C. Xu, Angew. Chem., Int. Ed. 2016, 55, 2226; For selected reports using Pd-catalysis, see: e) J. A. Fritz, J. S. Nakhla, J. P. Wolfe, Org. Lett. 2006, 8, 2531; f) B. A. Hopkins, J. P. Wolfe, Angew. Chem., Int. Ed. 2012, 51, 9886; g) B. P. Zavesky, N. R. Babij, J. A. Fritz, J. P. Wolfe, Org. Lett. 2013, 15, 5420; h) R. M. Fornwald, J. A. Fritz, J. P. Wolfe, Chem. Eur. J. 2014, 20 , 8782; i) Z. J. Garlets, K. R. Parenti, J. P. Wolfe, Chem. Eur. J. 2016, 22 , 5919; j) R. I. McDonald, S. S. Stahl, Angew. Chem., Int. Ed. 2010, 49, 5529; k) T. Wu, J. Cheng, P. Chen, G. Liu, Chem. Commun. 2013, 49, 8707.

[7] a) R. Amoroso, G. Cardillo, C. Tomasini, Tetrahedron Lett. 1991, 32, 1971; b) R. Amoroso, G. Cardillo, C. Tomasini, Heterocycles 1992, 34, 349; c) R. Amoroso, G. Cardillo, C. Tomasini, P. Tortoreto, J. Org. Chem. 1992, 57, 1082; d) D. Yoo, S. Kwon, Y. G. Kim, Tetrahedron: Asymmetry 2005, 16, 3762; e) S. Fustero, D. Jimenez, J. Moscardo, S. Catalan, C. del Pozo, Org. Lett. 2007, 9, 5283.

[8] For selected examples of imidazolidine derivatization, see: a) G. W. Nyce, S. Csihony, R. M. Waymouth, J. L. Hedrick, Chem. Eur. J. 2004, 10, 4073; b) J. Savoie, B. Stenne, S. K. Collins, Adv. Synth. Catal. 2009, 351, 1826; c) H. Xie, J. Zhu, Z. Chen, S. Li, Y. Wu, J. Org. Chem. 2010, 75, 7468; d) Y. Saima, S. Khamarui, K. S. Gayen, P. Pandit, D. K. Maiti, Chem. Commun. 2012, 48, 6601

[9] a) R. A. T. M. Van Benthem, H. Hiemstra, G. R. Longarela, W. N Speckamp, Tetrahedron Lett. 1994, 35, 9281; b) M. J. MacDonald, D. J. Schipper, P. J. Ng, J. Moran, A. M. Beauchemin, J. Am. Chem. Soc 2011, 133, 20100; c) N. Guimond, M. J. MacDonald, V. Lemieux, A. M. Beauchemin, J. Am. Chem. Soc. 2012, 134, 16571; d) S. Zhao, E. Bilodeau, V. Lemieux, A. M. Beauchemin, Org. Lett. 2012, 14, 5082; e) M. J. MacDonald, C. R. Hesp, D. J. Schipper, M. Pesant, A. M Beauchemin, Chem. Eur. J. 2013, 19, 2597; f) C. R. Hesp, M. J. MacDonald, M. M. Zahedi, D. A. Bilodeau, S.-B. Zhao, M. Pesant, A. M Beauchemin, Org. Lett. 2015, 17, 5136.

[10] a) U. Orcel, J. Waser, Angew. Chem., Int. Ed. 2015, 54, 5250; For stepwise approaches involving hemi-aminals for Wacker cyclization, see: b) R. A. T. M. Van Benthem, H. Hiemstra, W. N. Speckamp, J. Org Chem. 1992, 57, 6082; c) R. A. T. M. van Benthem, H. Hiemstra, G. R. Longarela, W. N. Speckamp, Tetrahedron Lett. 1994, 35, 9281; d) A. B. Weinstein, D. P. Schuman, Z. X. Tan, S. S. Stahl, Angew. Chem., Int. Ed. 2013, 52, 11867

[11] See Scheme $S 1$ in the Supporting Information for a more detailed discussion of the speculative reaction mechanism.

[12] a) S. Nicolai, J. Waser, Org. Lett. 2011, 13, 6324; b) S. Nicolai, R. Sedigh-Zadeh, J. Waser, J. Org. Chem. 2013, 78, 3783.

[13] L. Ingrassia, M. Mulliez, Synthesis, 1999, 1731. See supporting information for details.

[14] a) M. Morales-Chamorro, J. Meza-Gonzalez, A. Cordero-Vargas, Tetrahedron Letters 2015, 56, 4892; b) G. A. Molander, P. J. Nichols, J. Org. Chem. 1996, 61, 6040.

[15] For the use of triflate salts as additive in carboamination reactions, see L. J. Peterson, J. P. Wolfe, Adv. Synth. Catal. 2015, 357, 2339 


\section{Entry for the Table of Contents}

\section{COMMUNICATION}

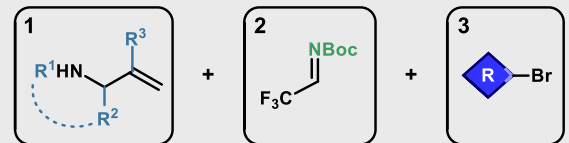

Alkynyl, vinyl and aryl bromides Wide substrate scope

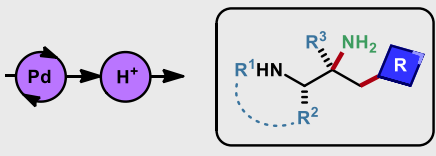

up to $99 \%$ yield up to $d r>98: 2$

A novel synthesis of vicinal diamines via in situ aminal formation and Pd-catalyzed carboamination of allylamines is reported herein. A wide variety of alkynyl, vinyl, aryl and hetereoaryl groups could be introduced with complete regioselectivity and high diastereoselectivity. Key to the reaction was the use of carbamate-protected trifluoromethyl aldimine in its stable hemiaminal form. Cleavage of the aminal tether was achieved in one step under mild conditions.

Ugo Orcel and Jerome Waser*

Page No. - Page No.

One-Pot Three-Component Vicinal Diamines Synthesis via In Situ Aminal Formation and Carboamination 


\section{Table of contents}

1. General Methods........................................................ 2

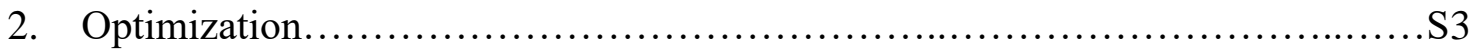

3. Proposed mechanism................................................ 6

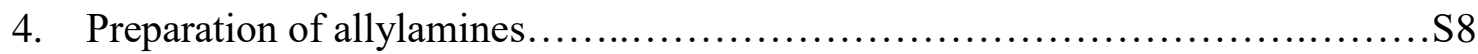

5. Preparation of aldimines....................................................

6. Preparation of bromoalkynes....................................... 20

7. Pd-catalyzed tandem aminal formatiom carbo-amination of allylamines.........S24

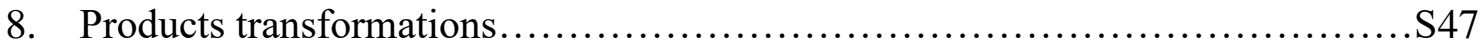

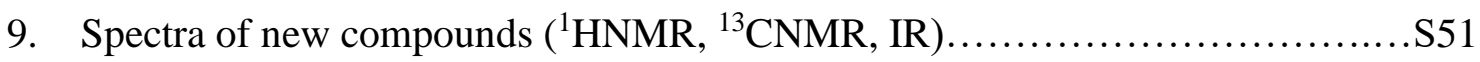




\section{General Methods}

All reactions were carried out in oven dried glassware under an atmosphere of nitrogen, unless stated otherwise. For quantitative flash chromatography technical grade solvents were used. For flash chromatography for analysis, HPLC grade solvents from Sigma-Aldrich were used. THF, $\mathrm{Et}_{2} \mathrm{O}, \mathrm{CH}_{3} \mathrm{CN}$, toluene, hexane and $\mathrm{CH}_{2} \mathrm{Cl}_{2}$ were dried by passage over activated alumina under nitrogen atmosphere $\left(\mathrm{H}_{2} \mathrm{O}\right.$ content $<10 \mathrm{ppm}$, Karl-Fischer titration). In some cases solvents were degassed using freeze-thaw cycle. All chemicals were purchased from Acros, Aldrich, Fluka, VWR, Fluorochem, Aplichem or Merck and used without further purification, unless stated otherwise. Chromatographic purification was performed as flash chromatography using Macherey-Nagel silica 40-63, $60 \AA$, using the solvents indicated as eluent with 0.1-0.5 bar pressure. TLC was performed on Merck silica gel $60 \mathrm{~F}_{254}$ TLC aluminium plates and visualized with UV light and potassium permanganate stain. Melting points were measured on a calibrated Büchi B-540 melting point apparatus using open glass capillaries. ${ }^{1} \mathrm{H}-\mathrm{NMR}$ spectra were recorded on a Bruker DPX-400 $400 \mathrm{MHz}$ spectrometer in chloroform-d unless otherwise stated. All signals are reported in ppm with the internal chloroform signal at $7.26 \mathrm{ppm}$ as standard unless otherwise stated. The data is being reported as $(\mathrm{s}=$ singlet, $\mathrm{d}=$ doublet, $\mathrm{t}=$ triplet, $\mathrm{q}=$ quadruplet, $\mathrm{qi}=$ quintet, $\mathrm{m}=$ multiplet or unresolved, $\mathrm{br}=$ broad signal, app = apparent, coupling constant(s) in $\mathrm{Hz}$, integration, interpretation). ${ }^{13} \mathrm{C}$-NMR spectra were recorded with ${ }^{1} \mathrm{H}$ decoupling on a Bruker DPX-400 $100 \mathrm{MHz}$ spectrometer in chloroform-d unless otherwise stated. All signals are reported in ppm with the internal chloroform signal at $77.16 \mathrm{ppm}$ as standard unless otherwise stated. Infrared spectra were recorded on a JASCO FT-IR B4100 spectrophotometer with an ATR PRO410-S and a ZnSe prisma and are reported as $\mathrm{cm}^{-1}(\mathrm{w}=$ weak, $\mathrm{m}=$ medium, $\mathrm{s}=$ strong, $\mathrm{br}=$ broad). Gas chromatographic and low resolution mass spectrometric measurements were performed on a Perkin-Elmer Clarus 600 gas chromatographer and mass spectrometer using a Perkin-Elmer Elite fused silica column (length: $30 \mathrm{~m}$, diameter: $0.32 \mathrm{~mm}$ ) and Helium as carrier gas. High resolution mass spectrometric measurements were performed by the mass spectrometry service of ISIC at the EPFL on a MICROMASS (ESI) QTOF Ultima API. Cesium carbonate was purchased from Aldrich and used without further purification. The bulk of this material was stored under nitrogen in a Vacuum Atmospheres Glovebox. Small portions (3-5 g) were removed from the glovebox in glass vials and weighed in the air. DPEPhos was purchased from Acros, PhDavePhos from ABCR and tri(2-furyl)phosphine was purchased from Aldrich. N-benzylprop-2-en-1-amine (1), N-(4-bromobenzyl)prop-2-en-1amine, N-(4-methoxybenzyl)prop-2-en-1-amine, N-(2-chlorobenzyl)prop-2-en-1-amine, diallylamine, $\quad \mathrm{N}$-(furan-2-ylmethyl)prop-2-en-1-amine, allylamine $\quad(49), \quad \mathrm{N}$-allyl-4methoxyaniline, N-benzyl-2-methylprop-2-en-1-amine and N,1-diphenylmethanimine (2b) are commercially available from Fluorochem, Aldrich and Acros. Aldimine $\mathbf{2 c},{ }^{1} \mathbf{2 d},{ }^{2} \mathbf{2 e},{ }^{3} \mathbf{2 g}^{\mathbf{4}}$ were synthesized according to reported procedures. Aryl and vinyl bromides were bought from Aldrich, Acros, ABCR, TCI and Fluorochem, and used as received. Diastereomeric mixtures have been assigned by 1D and 2D NMR experiments including COSY/NOESY/HSQC/HMBC.

\footnotetext{
${ }^{1}$ Wenzel, A. G.; Jacobsen, E. N. J. Am. Chem. Soc. 2002, 124, 12964.

${ }^{2}$ Nugent, B. M.; Yoder, R. A.; Johnston, J. N J. Am. Chem. Soc. 2004, 126, 3418.

${ }^{3}$ Mimura, H.; Kawada, K.; Yamashita, T.; Sakamoto, T.; Kikugawa, Y J. Fluor. Chem. 2010, $131,477$.

${ }^{4}$ Kumadaki, I.; Jonoshita, S.; Harada, A.; Omote, M.; Ando, A. J. Fluor. Chem. 1999, 97, 61.
} 


\section{Optimization.}

General method for the optimization:

A sealed oven-dry microwave vial under nitrogen was charged with dry degassed toluene $(0.3$ $\mathrm{mL})$, the tether, the allylamine $(0.100 \mathrm{mmol}, 1.0 \mathrm{eq})$, the base and (bromoethynyl)triisopropylsilane $(34 \mathrm{mg}, 0.13 \mathrm{mmol}, 1.3 \mathrm{eq})$. The resulting solution was stirred 30-60 min at $50{ }^{\circ} \mathrm{C}$. Then a premixed solution of the palladium source and the ligand in dry degassed toluene $(0.20 \mathrm{~mL})$ was added. The resulting mixture was stirred at $60-70{ }^{\circ} \mathrm{C}$ for $15-20$ $\mathrm{h}$. The reaction mixture was cooled to $23{ }^{\circ} \mathrm{C}$, filtered and concentrated under reduced pressure and analyzed by NMR spectroscopy. The yield was determined using either 3,4,5trichloropyridine for ${ }^{1} \mathrm{H}$ NMR (integration of propargylic protons) or benzotrifluoride for the ${ }^{19} \mathrm{~F}$ NMR as internal standards.

Table 1. Optimization for the mono-substituted allyl amines.

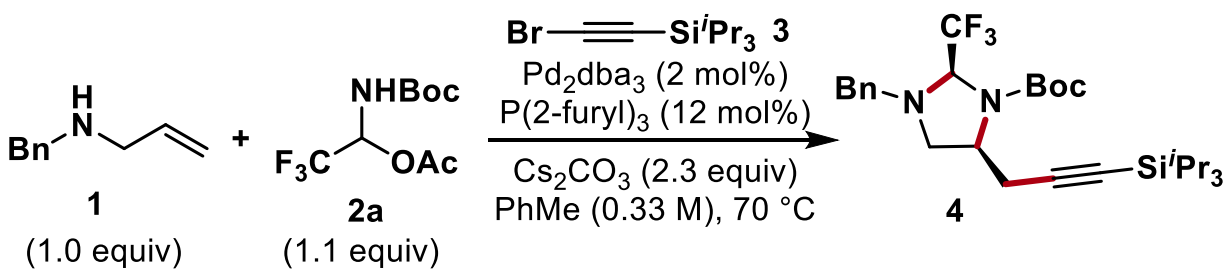

\begin{tabular}{|c|c|c|}
\hline Entry & Changes from standard conditions & Yield $(\%)^{b}$ \\
\hline 1 & none & $99(95)^{c}$ \\
\hline 2 & $\mathrm{Na}_{2} \mathrm{CO}_{3}$ instead of $\mathrm{Cs}_{2} \mathrm{CO}_{3}$ & $<5$ \\
\hline 3 & $\mathrm{Rb}_{2} \mathrm{CO}_{3}$ instead of $\mathrm{Cs}_{2} \mathrm{CO}_{3}$ & 80 \\
\hline 4 & $\mathrm{KO} t-\mathrm{Bu}$ instead of $\mathrm{Cs}_{2} \mathrm{CO}_{3}$ & 78 \\
\hline 5 & MTBD instead of $\mathrm{Cs}_{2} \mathrm{CO}_{3}$ & 38 \\
\hline 6 & Phosphazene $\mathrm{P}_{2}$ Et instead of $\mathrm{Cs}_{2} \mathrm{CO}_{3}$ & 55 \\
\hline 7 & 1.8 equiv of $2 \mathrm{a}$ instead of 1.1 & 94 \\
\hline 8 & 2.5 equiv of $2 \mathrm{a}$ instead of 1.1 & 76 \\
\hline 9 & $0.4 \mathrm{M}$ instead of $0.33 \mathrm{M}$ & 92 \\
\hline 10 & $0.2 \mathrm{M}$ instead of $0.33 \mathrm{M}$ & 80 \\
\hline 11 & $1 \mathrm{~mol} \%$ of $\mathrm{Pd}_{2} \mathrm{dba}_{3}$ instead of $2 \mathrm{~mol} \%$ & 81 \\
\hline 12 & {$[($ cinnamyl $) \mathrm{PdC}]$ instead of $\mathrm{Pd}_{2} \mathrm{dba}_{3}$} & 88 \\
\hline
\end{tabular}

${ }^{a}$ Reaction conditions: $0.10 \mathrm{mmol}$ 1, $0.11 \mathrm{mmol} 2 \mathrm{a}, 0.13 \mathrm{mmol}$ 3, $0.33 \mathrm{M}$ in PhMe, 20 h. ${ }^{b} \mathrm{NMR}$ yield using 3,4,5-trichloropyridine as internal standard. 'Isolated yield on $0.30 \mathrm{mmol}$ scale. 
Table 2. Optimization for the gem-disubstituted allyl amines.

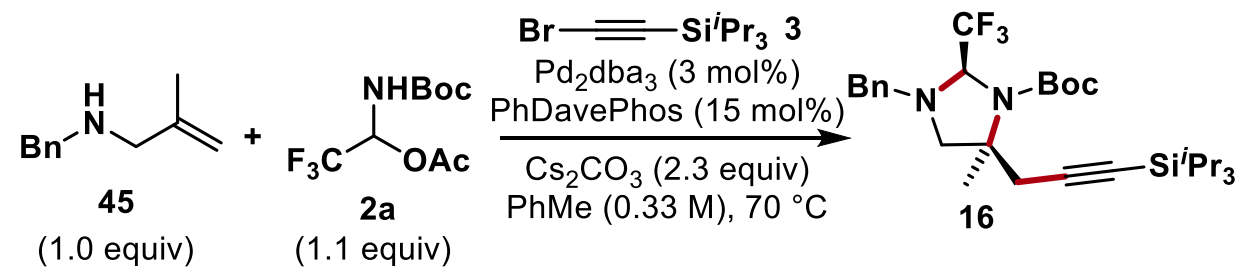

\begin{tabular}{clc}
\hline Entry & \multicolumn{1}{c}{ Changes from standard conditions } & Yield $(\%)^{b}$ \\
\hline 1 & none & $93(85)^{c}$ \\
2 & DPEPhos (9 mol\%) instead of PhDavePhos & 40 \\
3 & XantPhos (9 mol\%) instead of PhDavePhos & 16 \\
4 & $\left(4-\mathrm{CF}_{3}-\mathrm{C}_{6} \mathrm{H}_{4}\right)$ DavePhos (15 mol\%) instead of & 13 \\
5 & $\mathrm{P}(2-\text { furyl })_{3}(18 \mathrm{~mol} \%)$ instead of PhDavePhos & 8 \\
6 & o.28 M instead of $0.33 \mathrm{M}$ & 85
\end{tabular}

${ }^{a}$ Reaction conditions: $0.10 \mathrm{mmol}$ 45, $0.11 \mathrm{mmol} 2 \mathrm{a}, 0.13 \mathrm{mmol}$ 3, $0.33 \mathrm{M}$ in PhMe, $20 \mathrm{~h} .{ }^{b} \mathrm{NMR}$ yield using 3,4,5-trichloropyridine as internal standard. 'Isolated yield on $0.30 \mathrm{mmol}$ scale.

Table 3. Optimization for the $\alpha$-branched substituted allyl amines.

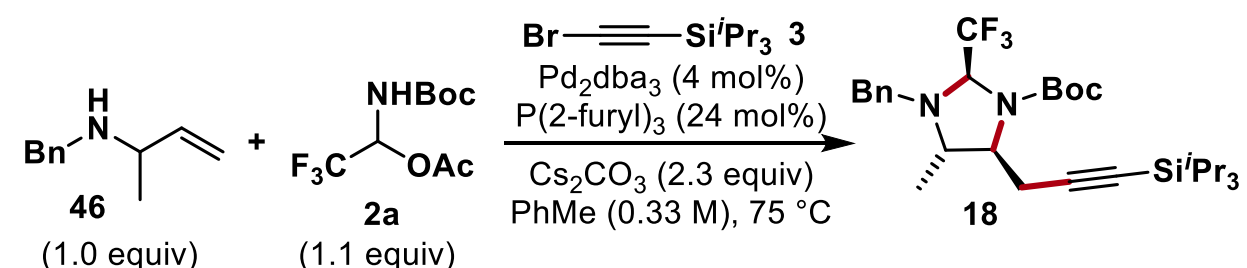

\begin{tabular}{|c|c|c|}
\hline Entry & Changes from standard conditions & Yield $(\%)^{b}$ \\
\hline 1 & none & 80 \\
\hline 2 & $0.05 \mathrm{M}$ instead of $0.33 \mathrm{M}$ & 32 \\
\hline 3 & $0.1 \mathrm{M}$ instead of $0.33 \mathrm{M}$ & 45 \\
\hline 4 & $0.2 \mathrm{M}$ instead of $0.33 \mathrm{M}$ & 75 \\
\hline 5 & $\mathrm{PPh}_{3}$ instead of $\mathrm{P}(2 \text {-furyl })_{3}$ & 7 \\
\hline 6 & $\mathrm{P}\left(4-\mathrm{CF}_{3}-\mathrm{C}_{6} \mathrm{H}_{4}\right)_{3}(24 \mathrm{~mol} \%)$ instead of $\mathrm{P}(2 \text {-furyl })_{3}$ & 31 \\
\hline 7 & $\mathrm{P}(\text { 2-thienyl })_{3}\left(24\right.$ mol\%) instead of $\mathrm{P}(\text { 2-furyl })_{3}$ & 18 \\
\hline 8 & $\mathrm{CyPPh}_{2}(24 \mathrm{~mol} \%)$ instead of $\mathrm{P}(2 \text {-furyl })_{3}$ & $<5$ \\
\hline 9 & dppf $(12 \mathrm{~mol} \%)$ instead of $\mathrm{P}(2 \text {-furyl })_{3}$ & $<5$ \\
\hline 10 & DPEPhos (12 mol\%) instead of $\mathrm{P}(2 \text {-furyl })_{3}$ & 35 \\
\hline 11 & XantPhos $(12 \mathrm{~mol} \%)$ instead of $\mathrm{P}(2 \text {-furyl })_{3}$ & 6 \\
\hline 12 & At $65{ }^{\circ} \mathrm{C}$ instead of $75^{\circ} \mathrm{C}$ & 62 \\
\hline
\end{tabular}


13 At $85^{\circ} \mathrm{C}$ instead of $75{ }^{\circ} \mathrm{C} \quad 70$

$14\left[(\right.$ cinnamyl) $\mathrm{PdCp}]$ instead of $\mathrm{Pd}_{2} \mathrm{dba}_{3} \quad 63$

$15 \operatorname{Pd}(\mathrm{dba})_{2}$ instead of $\mathrm{Pd}_{2} \mathrm{dba}_{3} \quad 64$

$16 \mathrm{Pd}(\mathrm{OAc})_{2}$ instead of $\mathrm{Pd}_{2} \mathrm{dba}_{3} \quad 42$

$17 \mathrm{PhCF}_{3}$ instead of PhMe 44

18 Dioxane instead of PhMe 53

$19 t$-amyl alcohol:PhMe 5:1 instead of PhMe $\quad 70$

$20 \mathrm{LiOt}$-Bu instead of $\mathrm{Cs}_{2} \mathrm{CO}_{3}$

$21 \mathrm{NaOt}$-Bu instead of $\mathrm{Cs}_{2} \mathrm{CO}_{3}$

$22 \mathrm{KOt}$-Bu instead of $\mathrm{Cs}_{2} \mathrm{CO}_{3} \quad 63$

23 With LiOTf (1.2 equiv) as additive 88

24 With NaOTf (1.2 equiv) as additive $\quad 85$

25 With KOTf (1.2 equiv) as additive $\quad 65$

26 With CsOTf (1.2 equiv) as additive 97

${ }^{a}$ Reaction conditions: $0.10 \mathrm{mmol}$ 46, o.11 mmol 2a, $0.13 \mathrm{mmol}$ 3, $0.33 \mathrm{M}$ in PhMe, 20 h. ${ }^{b} \mathrm{NMR}$ yield using trifluorotoluene as internal standard.

Table 4. Optimization for the aryl bromides.

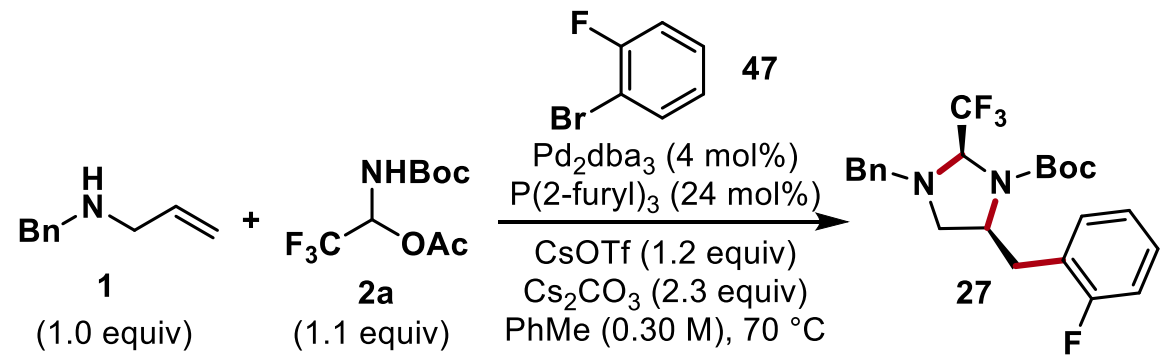

\begin{tabular}{clc}
\hline Entry & \multicolumn{1}{c}{ Changes from standard conditions } & Yield $(\%)^{b}$ \\
\hline 1 & none & $90(82)^{c}$ \\
2 & without CsOTf & 41 \\
3 & DPEPhos (12 mol\%) instead of P(2-furyl $)_{3}$ & 83 \\
4 & DPEPhos (12 mol\%) instead of P(2-furyl $)_{3}$ without CsOTf & 78 \\
5 & XANTPhos (12 mol\%) instead of P(2-furyl $)_{3}$ without CsOTf & 65 \\
6 & ${\text { PhDavePhos }(20 \text { mol\%) instead of P(2-furyl })_{3} \text { without CsOTf }}_{2}$ & 15 \\
7 & At 50 ${ }^{\circ} \mathrm{C}$ instead of $70^{\circ} \mathrm{C}$. & 30
\end{tabular}

${ }^{a}$ Reaction conditions: $0.10 \mathrm{mmol} \mathrm{1,} 0.11 \mathrm{mmol} 2 \mathrm{a}, 0.15 \mathrm{mmol} 47$, CsOTf (1.2 equiv), $0.30 \mathrm{M}$ in PhMe, 20 h. ${ }^{b}$ NMR yield using 3,4,5-trichloropyridine as internal standard. 


\section{Proposed mechanism.}

Based on observations and detailed mechanistic studies of the Wolfe's group, ${ }^{5}$ and observation in our group, ${ }^{6}$ we proposed the following mechanism for the aminoalkynylation reaction (Scheme S1). First oxidative addition of alkynyl bromide $\mathbf{3}$ onto the $\mathrm{Pd}^{0}$ catalyst I would form $\mathrm{Pd}^{\mathrm{II}}$-alkynyl intermediate II. Ligand exchange of the bromine with the in situ generated mixed aminal $\mathbf{V}$ give complex VII. Then, intramolecular aminopalladation of the olefins would likely occur in a syn manner to deliver the alkyl-Pd complex VII. Finally, reductive elimination would yield the imidazolidine IX and regenerate the $\mathrm{Pd}^{0}$ catalyst $\mathbf{I}$. The diastereoselectivity observed would arise from a highly organized chair-like transition-state in which the Pd-N bond is eclipsed with the olefin. The $\mathrm{CF}_{3}$ would adopt a pseudo-axial conformation to minimize $\mathrm{A}^{1,3}$-strain with the Boc group, while the $\mathrm{R}^{1}$ group would adopt a pseudo-equatorial conformation to minimize 1,3-diaxial interaction.

Regarding the formation of the mixed aminal $\mathbf{V}$, it would start with the formation of the Bocprotected trifluoromethyl aldimine III under basic conditions. Subsequent nucleophilic addition of allylamine IV onto III would yield $\mathbf{V}$. The stability of $\mathbf{V}$ most likely arises from the trifluoromethyl group that disfavor the formation of highly destabilized iminium VI.

${ }^{5}$ (a) J. E. Ney, J. P. Wolfe, J. Am. Chem. Soc., 2005, 127, 8644. (b) J. D. Neukom, N. S. Perch, J. P. Wolfe, J. Am. Chem. Soc., 2010, 132, 6276. (c) J. D. Neukom, N. S. Perch, J. P. Wolfe, Organometallics, 2011, $30,1269$.

${ }^{6}$ S. Nicolai, R. Sedigh-Zadeh, J. Waser, J. Org. Chem 2013, 78, 3783. 


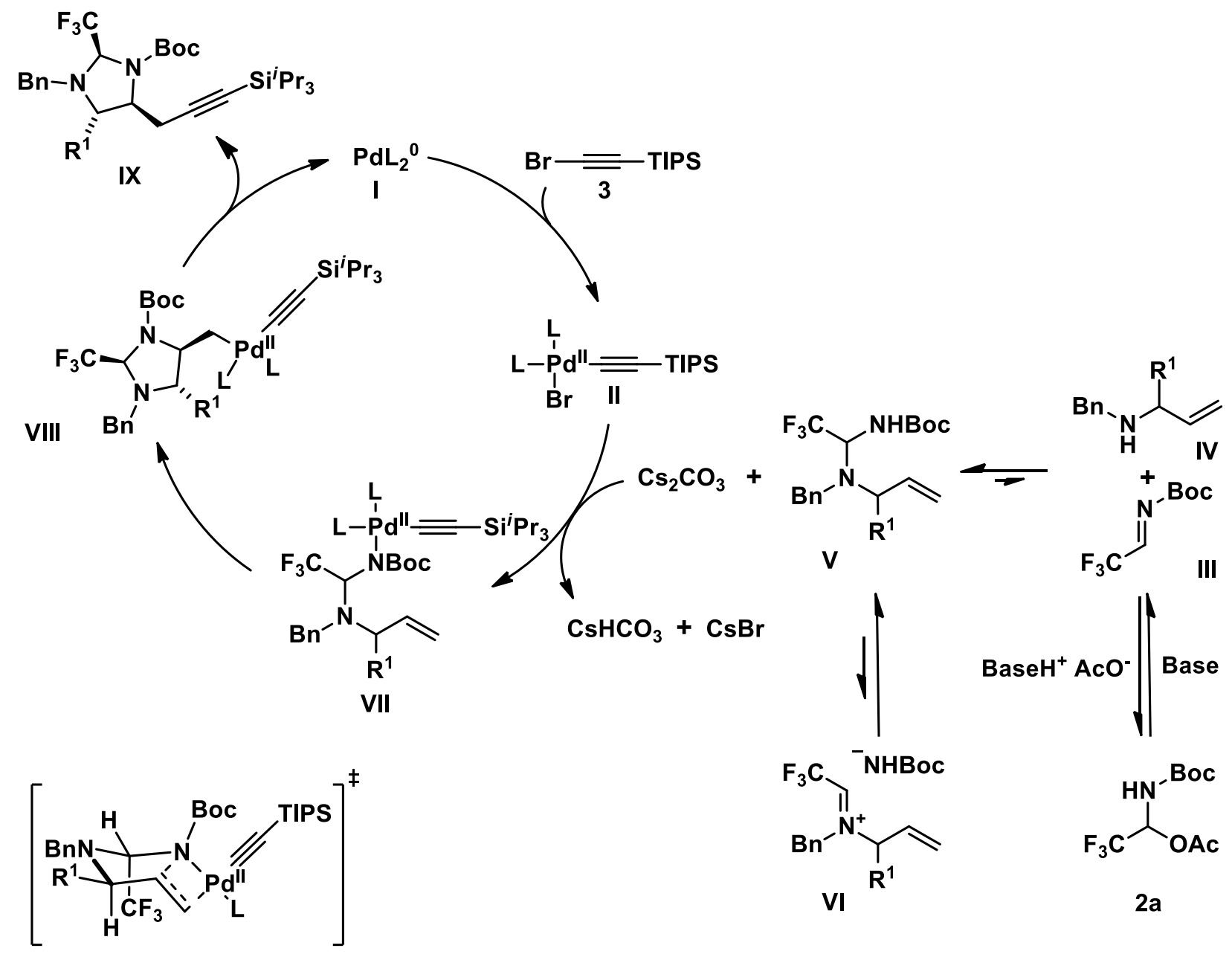

Scheme S1. Proposed mechanism for the aminoalkynylation reaction. 


\section{Preparation of allylamines.}

N-(4-(Trifluoromethyl)benzyl)prop-2-en-1-amine (50)
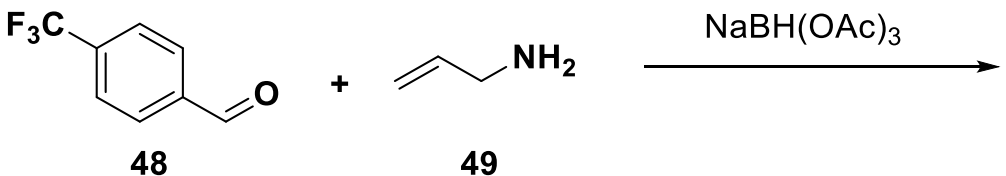

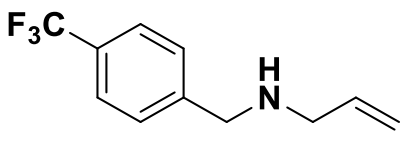

50

4-(Trifluoromethyl)benzaldehyde (48) $(1.37 \mathrm{~mL}, 10.0 \mathrm{mmol}, 1.0 \mathrm{eq})$ and prop-2-en-1-amine (49) $(0.571 \mathrm{~g}, 10.0 \mathrm{mmol}, 1.0 \mathrm{eq})$ were mixed in 1,2-dichloroethane $(35 \mathrm{~mL})$ and then treated with sodium triacetoxyborohydride $(3.0 \mathrm{~g}, 14 \mathrm{mmol},, 1.4 \mathrm{eq})$. The mixture was stirred at $\mathrm{rt}$ under a $\mathrm{N}_{2}$ atmosphere for $2.5 \mathrm{~h}$. The reaction mixture was quenched by adding aqueous saturated $\mathrm{NaHCO}_{3}$ $(15 \mathrm{~mL})$, and the product was extracted with EtOAc $(3 \times 30 \mathrm{~mL})$. The EtOAc extract was dried $\left(\mathrm{MgSO}_{4}\right)$, and the solvent was evaporated under reduced pressure. The crude product was purified by column chromatography $\left(\mathrm{SiO}_{2}, 10: 1: 0.1\right.$ Pentane:EtOAc:Et $\left.3 \mathrm{~N}\right)$ to afford the title compound $\mathbf{5 0}$ as a pale yellow oil $(1.83 \mathrm{~g}, 8.50 \mathrm{mmol}, 85 \%$ yield $)$.

$\mathbf{R}_{\mathbf{f}} 0.20$ (Pentane:EtOAc 4:1).

${ }^{1} \mathbf{H}$ NMR $(400 \mathrm{MHz}$, Chloroform- $d$ ) $\delta 7.58(\mathrm{~d}, J=8.0 \mathrm{~Hz}, 2 \mathrm{H}, \operatorname{Ar} H), 7.45(\mathrm{~d}, J=8.0 \mathrm{~Hz}, 2 \mathrm{H}$, $\mathrm{ArH}$ ), 5.92 (ddt, $\left.J=17.2,10.3,6.0 \mathrm{~Hz}, 1 \mathrm{H}, \mathrm{CHCH}_{2}\right), 5.21\left(\mathrm{~m}, 1 \mathrm{H}, \mathrm{CHCH}_{2}\right), 5.14(\mathrm{~m}, 1 \mathrm{H}$, $\mathrm{CHCH}_{2}$ ), 3.86 (s, $\left.2 \mathrm{H}, \mathrm{ArCH}_{2}\right), 3.28$ (m, 2H, $\left.\mathrm{NCH}_{2}\right), 1.65$ (bs, $\left.1 \mathrm{H}, \mathrm{NH}\right)$.

${ }^{13}$ C NMR (101 MHz, Chloroform- $d$ ) $\delta$ 144.4, 136.5, $129.4(\mathrm{q}, J=32.2 \mathrm{~Hz}), 128.5,125.5(\mathrm{~m})$, 124.5 (q, $J=272.2 \mathrm{~Hz}), 116.5,52.7,51.8$.

IR $v_{\max } 3394$ (w), 2831 (w), 2830 (w), 1646 (w), 1620 (w), 1458 (w), 1420 (w), 1329 (s), 1167 (m), 1127 (s), 1069 (w), 1021 (w), 925 (w), 844 (w), 823 (w), 796 (w), $784(w), 763(w), 728$ (w).

HRMS (ESI) calcd. for $\mathrm{C}_{11} \mathrm{H}_{13} \mathrm{~F}_{3} \mathrm{~N}^{+}[\mathrm{M}+\mathrm{H}]^{+}$216.0995; found 216.0994 .

\section{4-((Allylamino)methyl)benzaldehyde (52)}

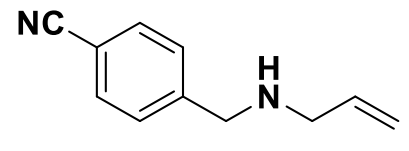

51

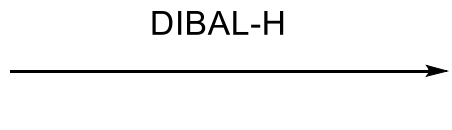

52

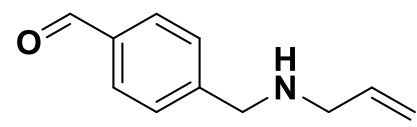

To a solution of commercially available 4-((allylamino)methyl)benzonitrile (51) $(0.861 \mathrm{~g}, 5.00$ mmol, 1.0 eq) in anhydrous toluene $(12.5 \mathrm{~mL})$ was added DIBAL-H $(1 \mathrm{M}$ in hexane, $6.50 \mathrm{~mL}$, $6.50 \mathrm{mmol}, 1.3 \mathrm{eq})$, keeping the internal temperature between -10 and $-5^{\circ} \mathrm{C}$. After stirring at $0{ }^{\circ} \mathrm{C}$ for $2 \mathrm{~h}$, ice cold $\mathrm{HCl}(10 \%$ aq. sol., $50 \mathrm{~mL})$ was added carefully. The layers were separated and the aqueous phase washed with $\mathrm{CH}_{2} \mathrm{Cl}_{2}(3 \times 15 \mathrm{~mL})$. The resulting aqueous layer was basified $(\mathrm{pH}$ 14) with $\mathrm{KOH}$ and extracted with $\mathrm{CH}_{2} \mathrm{Cl}_{2}(3 \times 50 \mathrm{~mL})$. The combined organic layers were washed with saturated aqueous $\mathrm{NaCl}$ and dried $\left(\mathrm{MgSO}_{4}\right)$. The solvent was evaporated to give the crude product that was purified by passing through a short pad of silica, eluting with EtOAc to afford the pure title compound $\mathbf{5 2}$ as a pale yellow oil $(0.797 \mathrm{~g}, 4.55 \mathrm{mmol}, 91 \%$ yield $)$.

$N$. B.: this compound readily polymerized, preventing us from obtaining a clean ${ }^{13} \mathrm{C} N M R$ spectrum.

${ }^{1} \mathbf{H}$ NMR (400 MHz, Chloroform- $d$ ) $\delta 10.00(\mathrm{~s}, 1 \mathrm{H}, \mathrm{CHO}), 7.89-7.78(\mathrm{~m}, 2 \mathrm{H}, \mathrm{ArH}), 7.57-7.45$ (m, $2 \mathrm{H}, \mathrm{ArH}$ ), 5.93 (ddt, $\left.J=17.1,10.2,6.0 \mathrm{~Hz}, 1 \mathrm{H}, \mathrm{CHCH}_{2}\right), 5.25-5.17\left(\mathrm{~m}, 1 \mathrm{H}, \mathrm{CHCH}_{2}\right), 5.16$ - $5.10\left(\mathrm{~m}, 1 \mathrm{H}, \mathrm{CHCH}_{2}\right), 3.89$ (s, $\left.2 \mathrm{H}, \mathrm{ArCH}_{2}\right), 3.29\left(\mathrm{~m}, 2 \mathrm{H}, \mathrm{NCH}_{2}\right), 1.52$ (bs, $\left.1 \mathrm{H}, \mathrm{NH}\right)$. 
IR $v_{\max } 3664$ (w), 3074 (w), 2995 (w), 2916 (w), 2827 (m), 2735 (w), 1698 (s), 1643 (w), 1607 (m), 1578 (w), 1449 (w), $1420(w), 1389(w), 1363(w), 1341(w), 1304(w), 1254(w), 1210(\mathrm{~m})$, $1166(\mathrm{~m}), 1108(\mathrm{w}), 1072(\mathrm{w}), 997(\mathrm{~m}), 922(\mathrm{~m}), 848(\mathrm{~m}), 823(\mathrm{~m}), 783(\mathrm{~m})$.

HRMS (ESI) calcd. for $\mathrm{C}_{11} \mathrm{H}_{14} \mathrm{NO}^{+}[\mathrm{M}+\mathrm{H}]^{+}$176.1070; found 176.1068.

\section{Ferrocenylmethyl allylamine (54)}

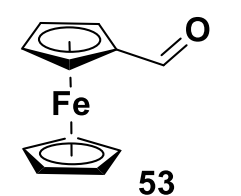

53
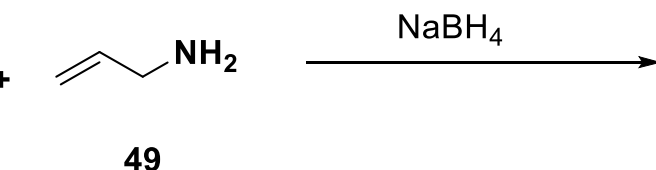

49

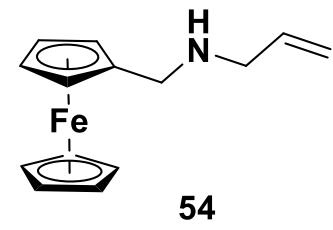

54

Following a slightly modified procedure, ${ }^{7}$ to a solution of ferrocenecarboxaldehyde (53) (700 mg, $3.27 \mathrm{mmol})$ in $\mathrm{MeOH}(14 \mathrm{~mL})$ was added allylamine (49) $(0.270 \mathrm{ml}, 3.60 \mathrm{mmol}, 1.1$ equiv) and the mixture was stirred at room temperature for $30 \mathrm{~min}$. The mixture was cooled to $0{ }^{\circ} \mathrm{C}$ and solid $\mathrm{NaBH}_{4}(0.148 \mathrm{~g}, 3.92 \mathrm{mmol}, 1.2$ equiv) was added in two portions. Then the solution was allowed to warm to room temperature and was stirred for another $30 \mathrm{~min}$. The solvent was removed, diluted with EtOAc and quenched with saturated aqueous $\mathrm{NaHCO}_{3}$. The organic layer was separated, washed with brine, dried over $\mathrm{MgSO}_{4}$, and concentrated under reduced pressure. Ferrocenylmethyl allylamine (54) was obtained as dark oil (750 mg, $3.22 \mathrm{mmol}, 90 \%)$ without further purification.

${ }^{1} \mathbf{H}$ NMR $\left(400 \mathrm{MHz}\right.$, Chloroform- $d$ ) $\delta 5.92\left(\mathrm{ddt}, J=16.5,10.3,6.0 \mathrm{~Hz}, 1 \mathrm{H}, \mathrm{CHCH}_{2}\right), 5.20(\mathrm{dd}, J$ $\left.=17.2,1.6 \mathrm{~Hz}, 1 \mathrm{H}, \mathrm{CHCH}_{2}\right), 5.12\left(\mathrm{dd}, J=10.3,1.6 \mathrm{~Hz}, 1 \mathrm{H}, \mathrm{CHCH}_{2}\right), 4.22-4.04(\mathrm{~m}, 9 \mathrm{H}$, Ferrocene $H$ ), 3.53 (s, $2 \mathrm{H}$, FerroceneC $\left.H_{2}\right), 3.29\left(\mathrm{~d}, J=6.0 \mathrm{~Hz}, 2 \mathrm{H}, \mathrm{NCH}_{2}\right), 1.67(\mathrm{~s}, 1 \mathrm{H}, \mathrm{NH})$.

${ }^{13}$ C NMR (101 MHz, Chloroform- $d$ ) $\delta$ 137.0, 116.0, 87.0, 68.5, 67.8, 52.1, 48.4.

Spectra data was consistent with the values reported in literature. ${ }^{7}$

N-benzyl-2-((benzyloxy)methyl)prop-2-en-1-amine (56)

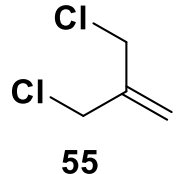

1) $\mathrm{NaH}, \mathrm{BnOH}$

2) $\mathrm{K}_{2} \mathrm{CO}_{3}, \mathrm{BnNH}_{2}$

55

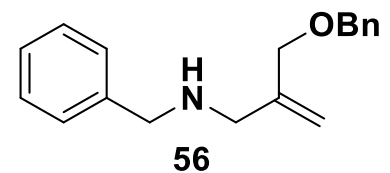

56

Multistep procedure:

1) Benzyl alcohol $(0.572 \mathrm{~mL}, 5.50 \mathrm{mmol}, 1.1$ equiv) was added to a mixture of $\mathrm{NaH}(120 \mathrm{mg}$, $5.00 \mathrm{mmol}, 1$ equiv) in THF $(5.0 \mathrm{~mL})$ at $\mathrm{rt}$. The reaction mixture was stirred for $1 \mathrm{~h}$ at this temperature and then slowly transferred to a solution of 3-chloro-2-(chloromethyl)prop-1-ene (55) $\left(656 \mathrm{mg}, 5.25 \mathrm{mmol}, 1.05\right.$ equiv) in THF (Ratio: 1.000 , Volume: $5.0 \mathrm{~mL}$ ) at $0{ }^{\circ} \mathrm{C}$. The reaction mixture was stirred for $12 \mathrm{~h}$ at $\mathrm{rt}$ and then quenched with $1 \mathrm{~N} \mathrm{HCl}$. The crude residue was purified by column chromatography on Biotage (SNAP cartridge KP-SIL 50 g, 99:1 to 92:8 Pentane: $\left.\mathrm{Et}_{2} \mathrm{O}\right)$ to afford a yellow oil $(0.530 \mathrm{~g}, 2.69 \mathrm{mmol}, 54 \%$ yield $)$ which was directly used in the next step.

2) (((2-(chloromethyl)allyl)oxy)methyl)benzene $(0.415 \mathrm{~g}, 2.11 \mathrm{mmol})$ was slowly added to a mixture of $\mathrm{K}_{2} \mathrm{CO}_{3}(0.350 \mathrm{~g}, 2.53 \mathrm{mmol})$ and phenylmethanamine $(1.20 \mathrm{~mL}, 11.2 \mathrm{mmol})$ at $0{ }^{\circ} \mathrm{C}$. The reaction mixture was stirred for $3 \mathrm{~h}$, diluted with DCM $(30 \mathrm{~mL})$, filtered and concentrated

\footnotetext{
${ }^{7}$ Gobe, V.; Retailleau, P.; Guinchard, X. Org. Lett. 2014, 16, 5438.
} 
under reduced pressure. The residue was purified by column chromatography $\left(\mathrm{SiO}_{2}\right.$,

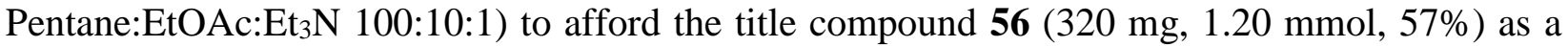
pale yellow oil.

$\mathbf{R}_{\mathbf{f}} 0.25$ (Pentane:EtOAc 4:1).

${ }^{1} \mathbf{H}$ NMR $(400 \mathrm{MHz}$, Chloroform- $d$ ) $\delta 7.37-7.29(\mathrm{~m}, 8 \mathrm{H}, \operatorname{Ar} H), 7.29-7.22(\mathrm{~m}, 2 \mathrm{H}, \operatorname{Ar} H), 5.20$ - $5.17\left(\mathrm{~m}, 1 \mathrm{H}, \mathrm{C}=\mathrm{CH}_{2}\right), 5.17-5.15\left(\mathrm{~m}, 1 \mathrm{H}, \mathrm{C}=\mathrm{CH}_{2}\right), 4.51\left(\mathrm{~s}, 2 \mathrm{H}, \mathrm{PhCH}_{2} \mathrm{O}\right), 4.07(\mathrm{~s}, 2 \mathrm{H}, \mathrm{O}$ $\left.\mathrm{CH}_{2} \mathrm{CCH}_{2}\right), 3.78\left(\mathrm{~s}, 2 \mathrm{H} \mathrm{PhCH} \mathrm{H}_{2} \mathrm{~N}\right), 3.36-3.30\left(\mathrm{~m}, 2 \mathrm{H}, \mathrm{CH}_{2} \mathrm{~N}\right), 1.58-1.38(\mathrm{~m}, 1 \mathrm{H}, \mathrm{NH})$.

${ }^{13}$ C NMR (101 MHz, Chloroform- $d$ ) $\delta 144.4,140.5,138.4,128.5,128.5,128.3,127.8,127.7$, 127.0, 113.4, 72.3, 72.2, 53.3, 51.7 .

IR $v_{\max } 3523$ (w), 3450 (w), 3347 (w), 3308 (w), 3068 (m), 3029 (m), 2842 (m), 1956 (w), 1877 (w), $1818(\mathrm{w}), 1683(\mathrm{w}), 1658(\mathrm{w}), 1603(\mathrm{w}), 1493(\mathrm{w}), 1451(\mathrm{~m}), 1365(\mathrm{w}), 1308(\mathrm{w}), 1080(\mathrm{~s})$, $1026(\mathrm{~m}), 974(\mathrm{w}), 912(\mathrm{~m}), 817(\mathrm{w})$.

HRMS (ESI) calcd. for $\mathrm{C}_{18} \mathrm{H}_{22} \mathrm{NO}^{+}[\mathrm{M}+\mathrm{H}]^{+}$268.1696; found 268.1691.

\section{N-Benzylbut-3-en-2-amine (46)}

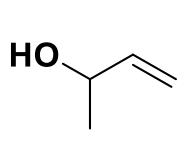

57

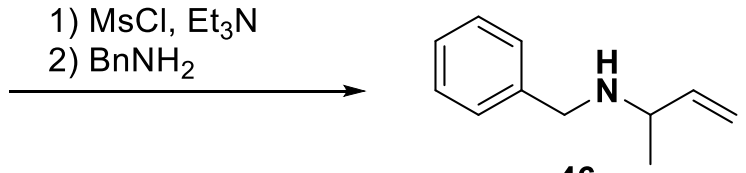

46

Following a reported procedure, ${ }^{8}$

1) $\mathrm{MeSO}_{2} \mathrm{Cl}(2.86 \mathrm{~g}, 25.0 \mathrm{mmol}, 1.25 \mathrm{eq})$ was added dropwise at $0{ }^{\circ} \mathrm{C}$ to a $\mathrm{CH}_{2} \mathrm{Cl}_{2}(60 \mathrm{~mL})$ solution of but-3-en-2-ol (57) (1.44 g, $20.0 \mathrm{mmol}, 1.0 \mathrm{eq})$ and $\mathrm{Et}_{3} \mathrm{~N}(3.04 \mathrm{~g}, 30.0 \mathrm{mmol}, 1.5 \mathrm{eq})$. The mixture was stirred at the same temperature for $2 \mathrm{~h}$, resulting in a large amount of white precipitate. Saturated $\mathrm{Na}_{2} \mathrm{CO}_{3}(30 \mathrm{~mL})$ was then added to quench the reaction. After the separation of the organic layer, extraction of the aqueous layer with $\mathrm{CH}_{2} \mathrm{Cl}_{2}(20 \mathrm{~mL} \times 2)$ and washing with brine, the combined organic layer was dried with $\mathrm{MgSO}_{4}$. The solvent was removed under reduced pressure, and the residue was dried under vacuum to afford but-3- en-2-yl methanesulfonate $(3.15 \mathrm{~g}, 21.0 \mathrm{mmol},<=100 \%)$, which was used directly in next step.

2) But-3-en-2-yl methanesulfonate $(2.13 \mathrm{~g}, 14.0 \mathrm{mmol}, 1.0 \mathrm{eq})$ was added dropwise to a rapidly stirring neat benzyl amine solution $(4.50 \mathrm{~g}, 42.0 \mathrm{mmol}, 3.0 \mathrm{eq})$ at room temperature. After stirring overnight, $\mathrm{NaOH}(10 \%, 10 \mathrm{~mL})$ was added. After extraction with $\mathrm{CH}_{2} \mathrm{Cl}_{2}(20 \mathrm{~mL})$, separation of organic layer, drying with $\mathrm{Na}_{2} \mathrm{SO}_{4}$, and removal of the solvent under reduced pressure, the residue was purified by column chromatography (EtOAc:Hexanes 3:1) to afford the title compound 46 as a colorless oil (2.48 g, $15.4 \mathrm{mmol}, 77 \%$ yield for 2 steps).

${ }^{1} \mathbf{H}$ NMR (400 MHz, Chloroform- $d$ ) $\delta$ 7.30-7.22 (m, 5H, ArH), $5.72(\mathrm{ddd}, J=17.6,10.1,7.6 \mathrm{~Hz}$ $\left.1 \mathrm{H}, \mathrm{CHCH}_{2}\right), 5.14\left(\mathrm{~m}, 1 \mathrm{H}, \mathrm{CHCH}_{2}\right), 5.09\left(\mathrm{~m}, 1 \mathrm{H}, \mathrm{CHCH}_{2}\right), 3.80\left(\mathrm{~d}, J=13.1 \mathrm{~Hz} 1 \mathrm{H}, \mathrm{PhCH}_{2}\right)$, $3.67\left(\mathrm{~d}, J=13.1 \mathrm{~Hz} 1 \mathrm{H}, \mathrm{PhCH}_{2}\right), 3.20(\mathrm{~m}, 1 \mathrm{H}, \mathrm{NCH}), 1.26(\mathrm{br}, \mathrm{NH}, 1 \mathrm{H}, \mathrm{NH}) 1.16(\mathrm{~d}, J=6.5 \mathrm{~Hz}$, $3 \mathrm{H}, \mathrm{Me})$.

${ }^{13}$ C NMR (100 MHz, Chloroform- $d$ ) $\delta$ 142.7, 140.8, 128.5, 128.3, 126.9, 114.8, 56.2, 51.5, 21.9. ${ }^{1} \mathrm{H}$ NMR data is consistent with the values reported in literature. ${ }^{9}$

\footnotetext{
${ }^{8}$ Zhao, S.-B.; Bilodeau, E.; Lemieux, V.; Beauchemin, A. M. Org. Lett. 2012, 14, 5082.

${ }^{9}$ Dubovyk, I.; Watson, I. D. G.; Yudin, A. K. J. Am. Chem. Soc. 2007, 129, 14172.
} 


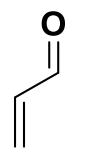

58
1) $t$ - BuS(O) $\mathrm{NH}_{2}, \mathrm{Ti}(\mathrm{OEt})_{4}$

2) Vinylmagnesium bromide

3) $\mathrm{BnBr}$, LiHMDS

4) $\mathrm{HCl}, \mathrm{MeOH}$

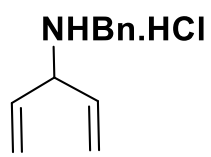

59

Multistep procedure:

1) Following a slightly modified procedure ${ }^{10}$ to a solution of acrylaldehyde (58) $(1.74 \mathrm{~mL}, 25.8$ mmol, 1.25 equiv) and 2-methylpropane-2-sulfinamide $(2.50 \mathrm{~g}, 20.6 \mathrm{mmol})$ in DCM (15 mL) was added tetraethoxytitanium $(12.1 \mathrm{~mL}, 58.0 \mathrm{mmol}, 2.8$ equiv). The mixture was stirred at room temperature for $1.5 \mathrm{~h}$, then poured into a mixture of ice/water and stirred for $30 \mathrm{~min}$. The white suspension was filtered through Celite and the cake rinsed with DCM. The organic layer was separated and the aqueous layer extracted with DCM $(3 \times 20 \mathrm{~mL})$. The combined organic layers were dried $\left(\mathrm{MgSO}_{4}\right)$ and concentrated in vacuo. Purification by column chromatography $\left(\mathrm{SiO}_{2}\right.$, DCM) afforded the desired imine $(2.53 \mathrm{~g}, 15.9 \mathrm{mmol}, 77 \%)$ as a light yellow oil.

2) Vinylmagnesium bromide (1.0 M solution in THF, $10.3 \mathrm{~mL}, 10.3 \mathrm{mmol}, 2$ equiv) was slowly added to a solution of the imine $(820 \mathrm{mg}, 5.15 \mathrm{mmol})$ in DCM $(26 \mathrm{~mL})$ at $-40{ }^{\circ} \mathrm{C}$. The reaction mixture was slowly warmed up to $\mathrm{rt}$ overnight. The reaction was quenched with a 1:1:1 mixture of water, brine and $\mathrm{NH}_{4} \mathrm{Cl}(30 \mathrm{~mL})$. The layers were separated and the aqueous layer extracted with DCM $(3 \times 20 \mathrm{~mL})$. The organic layers were combined, dried over $\mathrm{MgSO}_{4}$, filtered and concentrated under reduced pressure. The crude oil was purified by column chromatography $\left(\mathrm{SiO}_{2}\right.$, Pentane:EtOAc 5:1 to 1:1) to afford the desired sulfinamide (460 mg, $2.46 \mathrm{mmol}, 48 \%$ ) which was directly engaged in the next step.

3) A flame-dried flask was charged with the sulfinamide (300 $\mathrm{mg}, 1.60 \mathrm{mmol})$ and DMF (5.3 $\mathrm{mL})$. The resulting solution was cooled to $-40{ }^{\circ} \mathrm{C}$. LiHMDS $(1 \mathrm{M}$ in THF, $1.60 \mathrm{~mL}, 1.60 \mathrm{mmol}$, 1.05 equiv) was added dropwise over 5 minutes. The solution was allowed to stir for $1 \mathrm{~h}$ at this temperature. Then benzyl bromide $(0.38 \mathrm{~mL}, 3.2 \mathrm{mmol}, 2$ equiv) was added dropwise over 10 minutes. At this time, the resulting solution was warmed up to room temperature and was stirred for $2 \mathrm{~h}$. The reaction was slowly quenched at $0{ }^{\circ} \mathrm{C}$ by the addition of a saturated aqueous solution of ammonium chloride, the layers of the resulting biphasic mixture were separated and the aqueous layer was extracted with EtOAc $(3 \mathrm{x})$. The combined organic layers were washed with water $(4 \mathrm{x})$ and brine $(2 \mathrm{x})$, dried over $\mathrm{MgSO}_{4}$, filtered, and concentrated under reduced pressure. The crude residue was purified by column chromatography $\left(\mathrm{SiO}_{2}\right.$, Pentane:EtOAc 20:1 to 4:1) to afford the desired sulfinamide (312 $\mathrm{mg}, 1.13 \mathrm{mmol}, 70 \%)$ which was directly engaged in the next step.

4) A solution of the sulfinamide $(220 \mathrm{mg}, 0.793 \mathrm{mmol})$ in methanol $(1.6 \mathrm{~mL})$ was treated with a $4 \mathrm{~N}$ solution of $\mathrm{HCl}$ in $\mathrm{CPME}\left(0.80 \mathrm{~mL}, 2.0 \mathrm{mmol}, 2.0\right.$ equiv) at $-78{ }^{\circ} \mathrm{C}$. The reaction mixture was then slowly warmed up to rt overnight. Nitrogen was bubbled in the reaction mixture for $10 \mathrm{~min}$ and then the solvent was removed under reduced pressure and the crude amine salt was triturated with cold ether to afford the pure title compound $\mathbf{5 9}(140 \mathrm{mg}, 0.668 \mathrm{mmol}, 84 \%$ yield) as a white solid.

m.p.: $146-147^{\circ} \mathrm{C}$.

${ }^{10}$ Bonazzi, S.; Cheng, B.; Wzorek, J. S.; Evans, D. A. J. Am. Chem. Soc. 2013, 135, 9338. 
${ }^{1} \mathbf{H}$ NMR (400 MHz, Acetonitrile-d $\left.d_{3}\right) \delta 9.90(\mathrm{~s}, 2 \mathrm{H}, \mathrm{NH}), 7.67-7.58(\mathrm{~m}, 2 \mathrm{H}, \mathrm{ArH}), 7.45-7.31$ $(\mathrm{m}, 3 \mathrm{H}, \mathrm{ArH}), 6.14\left(\mathrm{ddd}, J=17.2,10.5,7.7 \mathrm{~Hz}, 2 \mathrm{H}, \mathrm{CH}=\mathrm{CH}_{2}\right), 5.45-5.43\left(\mathrm{~m}, 2 \mathrm{H}, \mathrm{CH}=\mathrm{CH}_{2}\right)$, $5.43-5.38\left(\mathrm{~m}, 2 \mathrm{H}, \mathrm{CH}=\mathrm{CH}_{2}\right), 4.12(\mathrm{~d}, J=6.8 \mathrm{~Hz}, 1 \mathrm{H}, \mathrm{NCH}), 4.02\left(\mathrm{~d}, J=4.7 \mathrm{~Hz}, 2 \mathrm{H}, \mathrm{PhCH}_{2}\right)$.

${ }^{13}$ C NMR (101 MHz, CD 3 CN) $\delta 132.8,132.1,131.5,130.0,129.6,122.67,63.3,49.1$.

IR $v_{\max } 3391(\mathrm{w}), 3077$ (w), 2927 (m), 2854 (w), 1638 (w), 1456 (m), $1301(\mathrm{w}), 1268$ (w), 1121 (w), 996 (m), 923 (s).

HRMS (ESI) calcd for $\mathrm{C}_{12} \mathrm{H}_{16} \mathrm{~N}^{+}[\mathrm{M}+\mathrm{H}]^{+}$174.1277; found 174.1277.

\section{2-vinylpyrrolidine hydrochloride (61)}
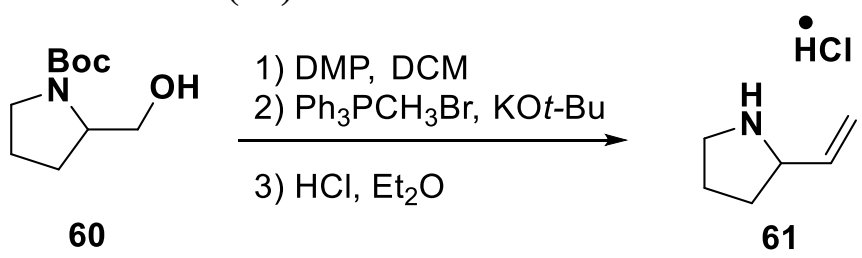

Multistep procedure:

1) DMP (3.56 g, $8.40 \mathrm{mmol}, 1.2$ equiv) was added portion-wise over $10 \mathrm{~min}$ to a stirred solution of commercially available tert-butyl 2-(hydroxymethyl)pyrrolidine-1-carboxylate (60) (1.41 g, $7.00 \mathrm{mmol})$ in DCM $(25 \mathrm{~mL})$. The reaction mixture was stirred at $\mathrm{rt}$ for $12 \mathrm{~h}$, then filtered over Celite and purified by column chromatography (Pentane:EtOAc 9:1) to afford the desired aldehyde (1.21 g, $6.07 \mathrm{mmol}, 87 \%)$ which was engaged directly in the next step.

2) Following a slightly modified procedure, ${ }^{11}$ methyltriphenylphosphonium bromide (3.93 g, 11.0 mmol, 2 equiv) was added to a stirred solution of potassium tert-butoxide $(1.23 \mathrm{~g}, 11.0 \mathrm{mmol}, 2$ equiv) in $\mathrm{Et}_{2} \mathrm{O}(25 \mathrm{~mL})$. The reaction mixture was stirred at reflux for $1 \mathrm{~h}$, then cooled down to -5 ${ }^{\circ} \mathrm{C}$ and a solution of tert-butyl 2-formylpyrrolidine-1-carboxylate (1.10 g, $\left.5.50 \mathrm{mmol}\right)$ in $\mathrm{Et}_{2} \mathrm{O}(25$ $\mathrm{mL}$ ) was added over $5 \mathrm{~min}$. The reaction mixture was stirred at $\mathrm{rt}$ for $3 \mathrm{~h}$. The reaction mixture was quenched with water $(20 \mathrm{~mL})$. The layers were separated and the aqueous one extracted with ether $(3 \times 10 \mathrm{~mL})$. The combined organic layers were washed with brine $(20 \mathrm{~mL})$, dried over $\mathrm{MgSO}_{4}$, filtered and concentrated under reduced pressure. The crude residue was purified by column chromatography $\left(\mathrm{SiO}_{2}\right.$, Pentane:EtOAc 10:1) to afford the desired olefin $(640 \mathrm{mg}, 3.24$ mmol, $59 \%$ yield) as an oil, which was engaged directly in the next step.

3) Following a slightly modified procedure, ${ }^{12}$ a $2 \mathrm{~N} \mathrm{HCl}$ solution $(4.8 \mathrm{~mL}, 9.7 \mathrm{mmol}, 3$ equiv) in ether was added to a stirred solution of tert-butyl 2-vinylpyrrolidine-1-carboxylate $(640 \mathrm{mg}, 3.24$ $\mathrm{mmol})$ in ether $(3 \mathrm{~mL})$ at $0{ }^{\circ} \mathrm{C}$. The reaction mixture was stirred at $\mathrm{rt}$ for $1 \mathrm{~h}$, then the volatiles were removed and the crude was washed with dry ether $(3 \times 2 \mathrm{~mL})$ and then dried under high vacuum for $1 \mathrm{~h}$ to afford the desired amine salt 61 (280 mg, $2.10 \mathrm{mmol}, 65 \%)$.

${ }^{1} \mathbf{H}$ NMR (400 MHz, $\left.\mathrm{CDCl}_{3}\right) \delta 10.0$ (bs, 1H, NH), 9.48 (bs, 1H, NH), 6.09 (ddd, $J=17.0,10.3$, $\left.7.6 \mathrm{~Hz}, 1 \mathrm{H}, \mathrm{CHCH}_{2}\right), 5.50\left(\mathrm{~d}, 1 \mathrm{H}, J=17.1 \mathrm{~Hz}, \mathrm{CHCH}_{2}\right), 5.38\left(\mathrm{~d}, 1 \mathrm{H}, J=10.3 \mathrm{~Hz}, \mathrm{CHCH}_{2}\right)$, 4.12-3.99 (m, $1 \mathrm{H}, \mathrm{NCH}), 3.48-3.26\left(\mathrm{~m}, 2 \mathrm{H}, \mathrm{NCH}_{2}\right), 2.24-1.96\left(\mathrm{~m}, 4 \mathrm{H}, 2 \mathrm{xCH}_{2}\right)$.

${ }^{13}$ C NMR (101 MHz, Chloroform- $d$ ) $\delta$ 132.4, 122.0, 62.6, 46.2, 31.2, 24.1.

Spectra data was consistent with the values reported in literature. ${ }^{13}$

\footnotetext{
${ }^{11}$ Morales-Chamorro, M.; Meza-Gonzlez, J.; Cordero-Vargas, A. Tetrahedron Letters, 2015, 56, 4892.

12 Donets, P. A.; Van der Eycken, E. V. Synthesis, 2011, 2147.

${ }^{13}$ Jurberg, I. D.; Peng, B.; Wöstefeld, E.; Wasserloos, M.; Maulide, N. Angew. Chem., Int. Ed. 2012, $51,1950$.
} 
2-vinylpiperidine 2,2,2-trifluoroacetate (63)
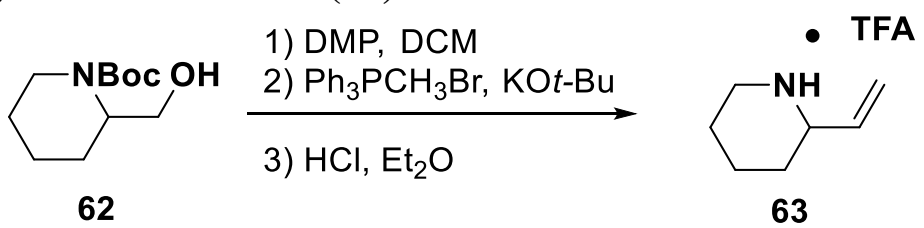

Multisptep procedure:

1) DMP (8.14 g, $19.2 \mathrm{mmol}, 1.6$ equiv) was added portion-wise over $10 \mathrm{~min}$ to a stirred solution of commercially available tert-butyl 2-(hydroxymethyl)piperidine-1-carboxylate (62) (2.58 g, $12.0 \mathrm{mmol})$ in DCM $(60 \mathrm{~mL})$. The reaction mixture was stirred at $\mathrm{rt}$ for $12 \mathrm{~h}$, then filtered over Celite and purified by column chromatography (EtOAc in pentane 12-20\%) to afford the desired aldehyde $(2.15 \mathrm{~g}, 10.1 \mathrm{mmol}, 84 \%)$ which was engaged in the next step.

2) Following a slightly modified procedure, ${ }^{14}$ methyltriphenylphosphonium bromide $(3.95 \mathrm{~g}, 11.1$ mmol, 2 equiv) was added to a stirred solution of potassium tert-butoxide (1.24 g, $11.1 \mathrm{mmol}, 2$ equiv) in $\mathrm{Et}_{2} \mathrm{O}(40 \mathrm{~mL})$. The reaction mixture was stirred at reflux for $1 \mathrm{~h}$, then cooled down to 0 ${ }^{\circ} \mathrm{C}$ and a solution of the aldehyde $(1.18 \mathrm{~g}, 5.53 \mathrm{mmol})$ in $\mathrm{Et}_{2} \mathrm{O}(10 \mathrm{~mL})$ was added over $5 \mathrm{~min}$. The reaction mixture was stirred at $\mathrm{rt}$ for $2 \mathrm{~h}$. The reaction mixture was quenched with water (20 $\mathrm{mL})$. The layers were separated and the aqueous one extracted with ether $(3 \times 10 \mathrm{~mL})$. The combined organic layers were washed with brine $(20 \mathrm{~mL})$, dried over $\mathrm{MgSO}_{4}$, filtered and concentrated under reduced pressure. The crude residue was purified by column chromatography $\left(\mathrm{SiO}_{2}\right.$, Pentane:Et ${ }_{2} \mathrm{O} 10: 1$ to 5:1) to afford the desired olefin $(1.03 \mathrm{~g}, 4.87 \mathrm{mmol}, 88 \%)$ as an oil, which was engaged directly in the next step.

3) To a solution of the olefin was added TFA (11.3 mL, $146 \mathrm{mmol}, 30$ equiv) at $0{ }^{\circ} \mathrm{C}$. The reaction mixture was stirred at $\mathrm{rt}$ for $3 \mathrm{~h}$ and then the volatiles were removed under reduced pressure. The crude residue was taken up in water $(40 \mathrm{~mL})$. The aqueous layer was washed with ether $(3 \times 20 \mathrm{~mL})$ and then concentrated under reduced pressure. The crude residue was dried by co-evaporation with toluene $(3 \times 10 \mathrm{~mL})$ to afford 2-vinylpiperidine 2,2,2-trifluoroacetate $(\mathbf{6 3})$ (1.05 g, $4.66 \mathrm{mmol}, 96 \%)$ as an oil as an oil.

${ }^{1} \mathbf{H}$ NMR (400 MHz, $\left.\mathrm{CDCl}_{3}\right) \delta 9.29$ (bs, 1H, NH), 8.76 (bs, 1H, NH), 5.84 (ddd, $J=17.4,10.5$, $\left.7.1 \mathrm{~Hz}, 1 \mathrm{H}, \mathrm{CHCH}_{2}\right), 5.39$ (dd, $\left.J=17.4,1.0 \mathrm{~Hz}, 1 \mathrm{H}, \mathrm{CHCH}_{2}\right), 5.31\left(\mathrm{~d}, J=10.5 \mathrm{~Hz}, 1 \mathrm{H}, \mathrm{CHCH}_{2}\right)$, $3.54(\mathrm{q}, J=10.3 \mathrm{~Hz}, 1 \mathrm{H}, \mathrm{NCH}), 3.37\left(\mathrm{~d}, J=12.6 \mathrm{~Hz}, 1 \mathrm{H}, \mathrm{NCH}_{2}\right), 2.98-2.86\left(\mathrm{~m}, 1 \mathrm{H}, \mathrm{NCH}_{2}\right)$, $1.97-1.88\left(\mathrm{~m}, 2 \mathrm{H}, 2 \mathrm{xNCH}_{2} \mathrm{CH}_{2}\right), 1.85-1.70\left(\mathrm{~m}, 3 \mathrm{H}, 2 \mathrm{xNCH}_{2} \mathrm{CH}_{2}\right.$ and $\left.\mathrm{NCH}_{2} \mathrm{CH}_{2} \mathrm{CH}_{2}\right), 1.58-$ $1.46\left(\mathrm{~m}, 1 \mathrm{H}, \mathrm{NCH}_{2} \mathrm{CH}_{2} \mathrm{CH}_{2}\right)$.

${ }^{13}$ C NMR $\left(101 \mathrm{MHz}, \mathrm{CDCl}_{3}\right) \delta 161.8(\mathrm{q}, J=36.8 \mathrm{~Hz}), 133.5,120.7,116.3(\mathrm{q}, J=289.2 \mathrm{~Hz})$, 58.8, 44.6, 28.7, 22.2, 22.0.

IR $v_{\max } 3501(\mathrm{w}), 3015(\mathrm{w}), 2840(\mathrm{w}), 2753(\mathrm{w}), 2533$ (w), 2436 (w), $1779(\mathrm{w}), 1670$ (s), 1431 (w), 1177 (s), 1135 (s), 992 (w), 944 (w), 838 (w).

HRMS (ESI) calcd for $\mathrm{C}_{7} \mathrm{H}_{14} \mathrm{~N}$ [M+] 112.1121; found 112.1116

\footnotetext{
${ }^{14}$ Molander, G. A.; Nichols, P. J. J. Org. Chem. 1996, 61, 6040.
} 

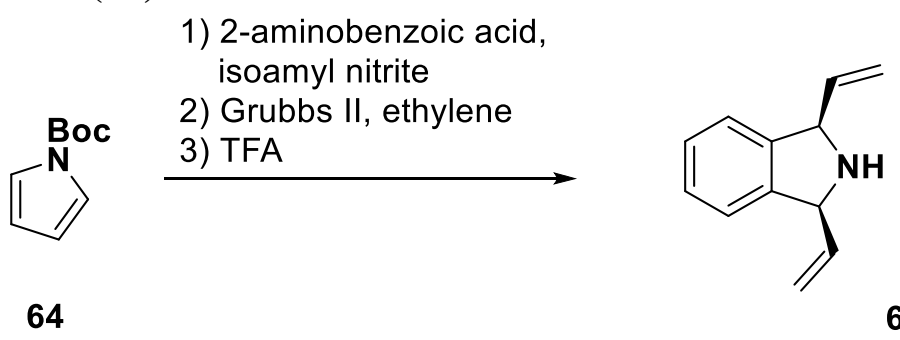

Multistep procedure:

1) Following a slightly modified procedure, ${ }^{15}$ isoamyl nitrite $(3.22 \mathrm{~mL}, 23.9 \mathrm{mmol}, 2$ equiv) was slowly added to a stirred solution of 2-aminobenzoic acid (2.050 g, $14.95 \mathrm{mmol}, 1.25$ equiv) and 2,2,2-trichloroacetic acid (17 mg, $0.11 \mathrm{mmol}, 0.9 \mathrm{~mol} \%)$ in dry THF $(35 \mathrm{~mL})$ at $0{ }^{\circ} \mathrm{C}$ for $30 \mathrm{~min}$ and the mixture was stirred at room temperature for $1.5 \mathrm{~h}$. The dark yellow precipitate of benzenediazonium-2-carboxylate was collected by filtration and washed with cold THF using minimal suction for draining taking care to prevent complete drying. The salt was immediately transferred to a flask. DCE (30 mL) and tert-butyl 1H-pyrrole-1-carboxylate (64) (2.00 g, 12.0 mmol) were added. The mixture was heated at $60{ }^{\circ} \mathrm{C}$ for $45 \mathrm{~min}$ and the black mixture was cooled to room temperature. After concentration under reduced pressure, the residue was purified by flash column chromatography (hexane/ethyl acetate $=95 / 5$ ) and recrystallization with hexane gave tert-butyl 1,4-dihydro-1,4-epiminonaphthalene-9-carboxylate (1.69 g, 6.95 mmol, $58 \%$ yield), which was directly used in the next step.

2) Following a slightly modified procedure, ${ }^{16}$ a $250 \mathrm{~mL}$ round-bottom flask equipped with a stirring bar and charged with tert-butyl 1,4-dihydro-1,4-epiminonaphthalene-9-carboxylate $(0.260 \mathrm{~g}, 1.07 \mathrm{mmol})$ and dry DCM $(105 \mathrm{~mL})$. The flask was put under house vacuum and backfilled with nitrogen $(3 \mathrm{x})$, then put under vaccum and backfilled with ethylene gas. The solution was stirred with an ethylene atmosphere for $30 \mathrm{~min}$ and then Grubbs II catalyst (27 $\mathrm{mg}$, $0.032 \mathrm{mmol}, 3 \mathrm{~mol} \%$ ) was added. The reaction was stirred at $\mathrm{rt}$ under ethylene atmosphere for 15 $\mathrm{h}$. Then 2 drops of water were added and solvent was then removed and the product purified by column chromatography (Pentane:EtOAc 97:3 to 92:8) affording tert-butyl cis-1,3divinylisoindoline-2-carboxylate $(238 \mathrm{mg}, 0.877 \mathrm{mmol}, 82 \%$ yield) as a pale yellow oil, which was directly used in the next step.

3) To a solution of tert-butyl cis-1,3-divinylisoindoline-2-carboxylate $(0.238 \mathrm{~g}, 0.978 \mathrm{mmol})$ in dry DCM (3 mL) at $0{ }^{\circ} \mathrm{C}$ was slowly added TFA (1.51 mL, $19.6 \mathrm{mmol}, 20$ equiv). The reaction mixture was stirred at $\mathrm{rt}$ for $1.5 \mathrm{~h}$ and then the volatiles were removed. The crude residue was taken up in $1 \mathrm{~N} \mathrm{NaOH}$ and extracted with DCM $(3 \times 10 \mathrm{~mL})$. The combined organic layers were dried over $\mathrm{MgSO}_{4}$, filtered and concentrated under reduced pressure. The compound was passed through a short plug of silica, eluting with pure ether to afford the title compound cis-1,3divinylisoindoline 65 (143 $\mathrm{mg}, 0.835 \mathrm{mmol}, 85 \%$ yield) as an oil.

$\mathbf{R}_{\mathbf{f}} 0.20$ (Pentane:EtOAc 4:1).

${ }^{1}$ H NMR (400 MHz, Chloroform- $d$ ) $\delta 7.32-7.26(\mathrm{~m}, 2 \mathrm{H}, \mathrm{ArH}), 7.21-7.15(\mathrm{~m}, 2 \mathrm{H}, \mathrm{ArH}), 5.92$ $\left(\mathrm{ddd}, J=16.9,9.9,7.9 \mathrm{~Hz}, 2 \mathrm{H}, \mathrm{CHCH}_{2}\right), 5.38\left(\mathrm{dt}, J=17.1,1.1 \mathrm{~Hz}, 2 \mathrm{H}, \mathrm{CHCH}_{2}\right), 5.22(\mathrm{dd}, J=$ $\left.10.0,1.6 \mathrm{~Hz}, 2 \mathrm{H}, \mathrm{CHCH}_{2}\right), 4.88(\mathrm{~d}, J=7.8 \mathrm{~Hz}, 2 \mathrm{H}, \mathrm{NCH}), 2.32(\mathrm{~s}, 1 \mathrm{H}, \mathrm{NH})$.

${ }^{13}$ C NMR (101 MHz, Chloroform- $d$ ) $\delta$ 142.9, 140.6, 127.4, 123.0, 116.3, 66.2.

\footnotetext{
${ }^{15}$ Cho, Y.-h.; Zunic, V.; Senboku, H.; Olsen, M.; Lautens, M. J. Am. Chem. Soc. 2006, 128, 6837.

${ }^{16}$ Bulchert, M.; Meinke, S.; Prenzel, A. H. G. P.; Deppermann, N.; Maison, W. Org. Lett. 2006, 8, 5553.
} 
IR $v_{\max } 3356(\mathrm{w}), 3075(\mathrm{w}), 2975(\mathrm{w}), 2804(\mathrm{w}), 1638(\mathrm{w}), 1611(\mathrm{w}), 1468(\mathrm{w}), 1420(\mathrm{w}), 1294$ (w), $1060(\mathrm{w}), 994(\mathrm{~m}), 925(\mathrm{~s})$.

HRMS (ESI) calcd. for $\mathrm{C}_{12} \mathrm{H}_{14} \mathrm{~N}^{+}[\mathrm{M}+\mathrm{H}]^{+} 172.1121$; found 172.1119. 


\section{Preparation of aldimines.}

\section{1-((Tert-butoxycarbonyl)amino)-2,2,2-trifluoroethyl acetate (2a)}

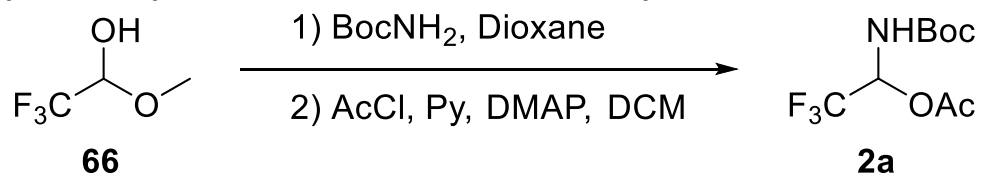

Following a slightly modified procedure, ${ }^{17}$ a $100 \mathrm{~mL}$ pressure tube was charged with tert-butyl carbamate (7.03 g, $60.0 \mathrm{mmol}), 2,2,2$-trifluoro-1-methoxyethanol (66) (7.69 mL, $66.0 \mathrm{mmol}, 1.1$ equiv), $4 \AA \mathrm{MS}(10 \mathrm{~g})$ and dioxane $(80 \mathrm{~mL})$. The tube was sealed under nitrogen atmosphere. The resulting mixture was heated at $100{ }^{\circ} \mathrm{C}$ for $5 \mathrm{~d}$ and then cooled down to rt. The mixture was filtered over Celite and the cake was washed with ether $(3 \times 20 \mathrm{~mL})$. The volatiles were removed under reduced pressure and the resulting solid was recrystallized in chloroform to afford white crystals $(8.20 \mathrm{~g}, 38.1 \mathrm{mmol}, 64 \%$ for 2 crops).

To a solution of pyridine (1.84 mL, $22.8 \mathrm{mmol}, 1.4$ equiv) and DMAP (50 mg, $0.41 \mathrm{mmol}, 2.5$ mol\%) in dichloromethane $(80 \mathrm{~mL})$ at $0{ }^{\circ} \mathrm{C}$ was slowly added acetyl chloride $(1.39 \mathrm{~mL}, 19.5$ mmol, 1.2 equiv). To the resulting mixture was added tert-butyl (2,2,2-trifluoro-1hydroxyethyl)carbamate $(3.50 \mathrm{~g}, 16.3 \mathrm{mmol})$ portion-wise. Then the mixture was stirred at $0{ }^{\circ} \mathrm{C}$ for $20 \mathrm{~min}$ and quenched with water $(10 \mathrm{~mL})$. The $\mathrm{pH}$ was adjusted to 2 by addition of $0.1 \mathrm{~N} \mathrm{HCl}$ and the layers were separated. The organic layer was washed with $0.1 \mathrm{~N} \mathrm{HCl}(3 \times 20 \mathrm{~mL})$ and brine $(30 \mathrm{~mL})$, dried over $\mathrm{MgSO}_{4}$, filtered and concentrated under reduced pressure. The crude residue was purified by column chromatography (Pentane:EtOAc 10:1) affording the title compound $2 \mathbf{a}$ (4.05 g, $15.8 \mathrm{mmol}, 97 \%$ yield) as a white solid.

m.p.: $60-61{ }^{\circ} \mathrm{C}$.

${ }^{1} \mathbf{H}$ NMR (400 MHz, Chloroform-d) $\delta 6.87-6.57\left(\mathrm{~m}, 1 \mathrm{H}, \mathrm{CHCF}_{3}\right), 5.48-5.16(\mathrm{~m}, 1 \mathrm{H}, \mathrm{NH})$, $2.14(\mathrm{~s}, 3 \mathrm{H}, \mathrm{Me}), 1.47(\mathrm{~s}, 9 \mathrm{H}, t-\mathrm{Bu})$.

${ }^{13}$ C NMR $\left(101 \mathrm{MHz}, \mathrm{CDCl}_{3}\right) \delta 168.2,153.1,121.8(\mathrm{q}, J=281.2 \mathrm{~Hz}), 82.3,72.1(\mathrm{q}, J=39.3 \mathrm{~Hz})$, $28.2,20.7$.

IR $v_{\max } 2984$ (w), 1770 (m), 1731 (m), 1522 (w), 1373 (m), 1252 (w), 1199 (s), 1162 (s), 1023 (m), $837(\mathrm{w})$.

HRMS (ESI) calcd for $\mathrm{C}_{9} \mathrm{H}_{14} \mathrm{~F}_{3} \mathrm{NNaO}_{4}{ }^{+}[\mathrm{M}+\mathrm{Na}]^{+}$280.0767; found 280.0770.

\section{2,2,2-Trifluoro-1-((methoxycarbonyl)amino)ethyl acetate (2aa)}

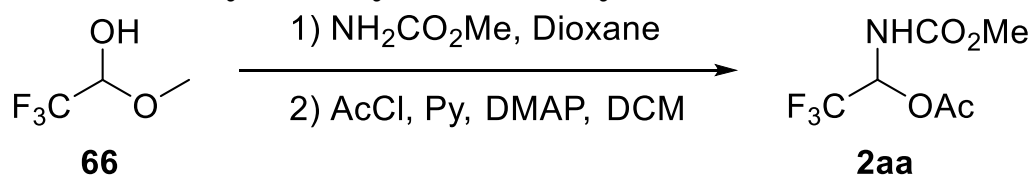

Following a slightly modified procedure, ${ }^{17}$ a $20 \mathrm{~mL}$ microwave vial was charged with methyl carbamate (2.25 g, $30.0 \mathrm{mmol}$ ), 2,2,2-trifluoro-1-methoxyethanol (66) (3.84 mL, $33.0 \mathrm{mmol}, 1.1$ equiv), $4 \AA \mathrm{MS}(4 \mathrm{~g})$ and was filled with dioxane $(\mathrm{ca} 16 \mathrm{~mL})$. The tube was sealed under nitrogen atmosphere. The resulting mixture was heated at $100{ }^{\circ} \mathrm{C}$ for $5 \mathrm{~d}$ and then cooled down to rt. The mixture was filtered over Celite and the cake was washed with ethyl acetate $(3 \times 20 \mathrm{~mL})$. The volatiles were removed under reduced pressure and the residue was purified by column

${ }^{17}$ Ingrassia, L.; Mulliez, M. Synthesis, 1999, 10, 1731. 
chromatography ( $\mathrm{SiO}_{2}$, Pentane:EtOAc 4:1) to afford the title compound (3.93 g, $22.7 \mathrm{mmol}, 75$ $\%$ yield) as a white solid.

To a solution of pyridine $(1.96 \mathrm{~mL}, 24.3 \mathrm{mmol}, 1.4$ equiv) and DMAP (53 mg, $0.43 \mathrm{mmol}, 2.5$ $\mathrm{mol} \%)$ in dichloromethane $(87 \mathrm{~mL})$ at $0{ }^{\circ} \mathrm{C}$ was slowly added acetyl chloride $(1.48 \mathrm{~mL}, 20.8$ mmol, 1.2 equiv). To the resulting mixture was added methyl (2,2,2-trifluoro-1hydroxyethyl)carbamate $(3.00 \mathrm{~g}, 17.3 \mathrm{mmol})$ portionwise. Then the mixture was stirred at $0{ }^{\circ} \mathrm{C}$ for $20 \mathrm{~min}$ and quenched with water $(10 \mathrm{~mL})$. The $\mathrm{pH}$ was adjusted to 2 by addition of $0.1 \mathrm{~N} \mathrm{HCl}$ and the layers were separated. The organic layer was washed with $0.1 \mathrm{~N} \mathrm{HCl}(3 \times 20 \mathrm{~mL})$ and brine $(30 \mathrm{~mL})$, dried over $\mathrm{MgSO}_{4}$, filtered and concentrated under reduced pressure. The crude residue was purified by column chromatography (Pentane:EtOAc 5:1) affording the title compound 2aa (3.55 g, $16.5 \mathrm{mmol}, 95 \%$ yield) as a white solid.

$\mathbf{R}_{\mathbf{f}} 0.50$ (Pentane:EtOAc 3:1).

m.p.: $84-86{ }^{\circ} \mathrm{C}$.

${ }^{1} \mathbf{H}$ NMR $(400 \mathrm{MHz}$, Chloroform- $d) \delta 6.90-6.66\left(\mathrm{~m}, 1 \mathrm{H}, \mathrm{CHCF}_{3}\right), 5.77-5.40(\mathrm{~m}, 1 \mathrm{H}, \mathrm{NH})$, 3.76 (s, 3H, OMe), 2.14 (s, 2H, Ac).

${ }^{13}$ C NMR $\left(101 \mathrm{MHz}, \mathrm{CDCl}_{3}\right) \delta 168.1,154.9,121.7(\mathrm{q}, J=281.0 \mathrm{~Hz}), 72.3(\mathrm{q}, J=36.9 \mathrm{~Hz}), 53.4$, 20.6 .

IR $v_{\max } 3316$ (w), 2996 (w), 2961 (w), 2225 (w), 1767 (s), 1732 (m), 1538 (m), 1381 (m), 1254 (s), 1208 (s), $1162(\mathrm{~s}), 1029(\mathrm{~s}), 966(\mathrm{~m})$.

HRMS (ESI) calcd for $\mathrm{C}_{6} \mathrm{H}_{8} \mathrm{~F}_{3} \mathrm{NNaO}_{4}{ }^{+}[\mathrm{M}+\mathrm{Na}]^{+}$238.0298; found 238.0299.

\section{4-((1-Ethoxy-2,2,2-trifluoroethyl)amino)benzonitrile (2f)}
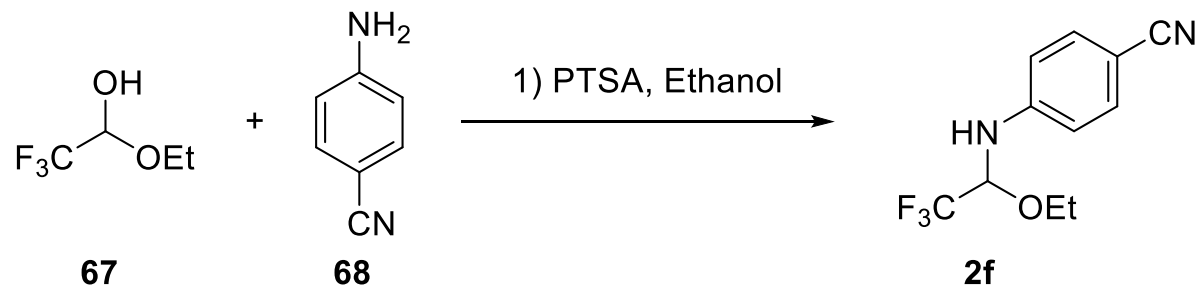

A round-bottomed flask equipped with a reflux condenser and a magnetic stirring bar was charged with 1-ethoxy-2,2,2-trifluoroethanol $(\mathbf{6 7})(2.20 \mathrm{~mL}, 16.1 \mathrm{mmol}, 3.35$ equiv) and ethanol $(10 \mathrm{~mL})$. Then 4-aminobenzonitrile $(\mathbf{6 8})(0.567 \mathrm{~g}, 4.80 \mathrm{mmol})$ and PTSA $(0.052 \mathrm{~g}, 0.30 \mathrm{mmol}$, $6.3 \mathrm{~mol} \%$ ) were added to the reaction flask, and the mixture was stirred at reflux. After the reaction was complete (monitoring by TLC, Pentane:EtOAc 4:1), and cooled to room temperature, $10 \%$ aqueous $\mathrm{NaHCO}_{3}(30 \mathrm{~mL})$ was added. The mixture was extracted with ethyl acetate $(2 \times 30 \mathrm{~mL})$, dried over $\mathrm{MgSO}_{4}$. The solvent was removed under reduced pressure and the residue was purified by column chromatography on Biotage (SNAP cartridge KP-SIL 50 g, 95:5 Pentane:EtOAc to 60:40 Pentane:EtOAc) to afford the title compound $2 \mathbf{f}(1.05 \mathrm{~g}, 4.30 \mathrm{mmol}, 90$ $\%$ yield) as a white solid.

$\mathbf{R}_{\mathbf{f}} 0.60$ (Pentane:EtOAc 4:1).

m.p.: $94-96{ }^{\circ} \mathrm{C}$.

${ }^{1} \mathbf{H}$ NMR (400 MHz, Chloroform- $d$ ) $\delta 7.55-7.43(\mathrm{~m}, 2 \mathrm{H}, \operatorname{Ar} H), 6.84-6.73(\mathrm{~m}, 2 \mathrm{H}, \operatorname{Ar} H), 5.10$ $\left(\mathrm{dq}, J=9.5,4.6 \mathrm{~Hz}, 1 \mathrm{H}, \mathrm{CF}_{3} \mathrm{CH}\right), 4.87(\mathrm{~d}, J=9.5 \mathrm{~Hz}, 1 \mathrm{H}, \mathrm{NH}), 3.75(\mathrm{dq}, J=9.3,7.1 \mathrm{~Hz}, 1 \mathrm{H}$, $\left.\mathrm{OCH}_{2}\right), 3.66\left(\mathrm{dq}, J=9.2,7.0 \mathrm{~Hz}, 1 \mathrm{H}, \mathrm{OCH}_{2}\right), 1.22(\mathrm{t}, J=7.0 \mathrm{~Hz}, 3 \mathrm{H}, \mathrm{Me})$.

${ }^{13} \mathrm{C}$ NMR $\left(101 \mathrm{MHz}, \mathrm{CDCl}_{3}\right) \delta 148.4,134.0,122.7(\mathrm{q}, J=283.7 \mathrm{~Hz}), 119.6,114.1,102.4,81.2$ (q, $J=34.1 \mathrm{~Hz}), 65.0,15.0$. 
IR $v_{\max } 3342$ (w), 2985 (w), 2220 (m), 1609 (s), 1525 (m), 1328 (w), 1259 (m), 1176 (s), 1140 (s), $1092(\mathrm{~s}), 913(\mathrm{w}), 829(\mathrm{~m})$.

HRMS (ESI) calcd for $\mathrm{C}_{11} \mathrm{H}_{12} \mathrm{~F}_{3} \mathrm{~N}_{2} \mathrm{O}^{+}[\mathrm{M}+\mathrm{H}]^{+}$245.0896; found 245.0893.

\section{N-(1-Ethoxy-2,2,2-trifluoroethyl)-4-nitrobenzenesulfonamide $(2 \mathrm{~h})^{18}$}

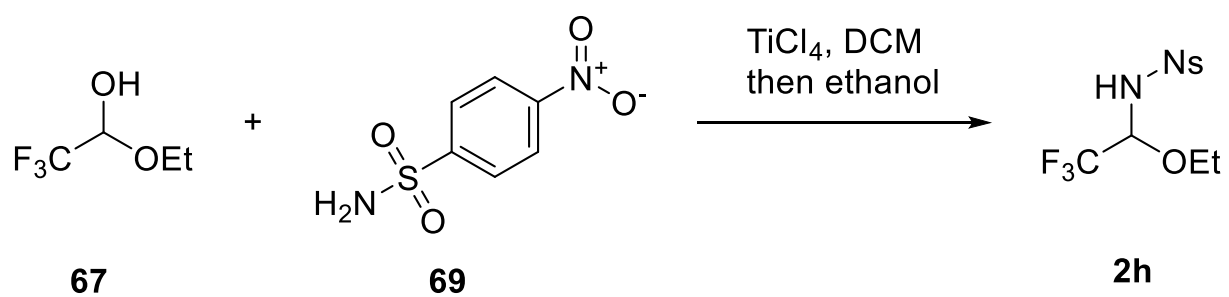

Following a slightly modified procedure, ${ }^{19}$ a round-bottomed flask equipped with a magnetic stirring bar under nitrogen atmosphere was charged with 4-nitrobenzenesulfonamide (69) (2.02 g, $10.0 \mathrm{mmol})$ and DCM (20 mL). Then 1-ethoxy-2,2,2-trifluoroethanol (67) (1.53 mL, $11.0 \mathrm{mmol}$, 1.1 equiv) and $\mathrm{TiCl}_{4}(2.21 \mathrm{~mL}, 20.0 \mathrm{mmol}, 2$ equiv) were added dropwise. The resulting mixture was stirred at $80{ }^{\circ} \mathrm{C}$ for $15 \mathrm{~h}$ and then treated with ethanol $(3.50 \mathrm{~mL}, 60.0 \mathrm{mmol}, 6$ equiv). The crude residue was purified by column chromatography $\left(\mathrm{SiO}_{2}\right.$, Pentane:EtOAc 3:1) to afford the title compound $\mathbf{2 h}(1.45 \mathrm{~g}, 4.42 \mathrm{mmol}, 44 \%)$ as a white solid.

$\mathbf{R}_{\mathbf{f}} 0.20$ (Pentane:EtOAc 3:1).

m.p.: $92-93{ }^{\circ} \mathrm{C}$.

${ }^{1}$ H NMR (400 MHz, Chloroform- $d$ ) $\delta 8.48-8.28$ (m, 2H, ArH), 8.20 - 7.91 (m, 2H, ArH), 5.42 $(\mathrm{d}, J=9.9 \mathrm{~Hz}, 1 \mathrm{H}, \mathrm{NH}), 5.03\left(\mathrm{dq}, J=9.9,4.5 \mathrm{~Hz}, 1 \mathrm{H}, \mathrm{CF}_{3} \mathrm{CH}\right), 3.88(\mathrm{dq}, J=9.5,7.0 \mathrm{~Hz}, 1 \mathrm{H}$, $\left.\mathrm{OCH}_{2}\right), 3.70\left(\mathrm{dq}, J=9.5,7.0 \mathrm{~Hz}, 1 \mathrm{H}, \mathrm{OCH}_{2}\right), 1.23(\mathrm{t}, J=7.0 \mathrm{~Hz}, 3 \mathrm{H}, \mathrm{Me})$.

${ }^{13} \mathrm{C} \mathrm{NMR}\left(101 \mathrm{MHz}, \mathrm{CDCl}_{3}\right) \delta 150.4,146.3,128.3,124.6,121.7(\mathrm{~d}, J=282.6 \mathrm{~Hz}), 81.6(\mathrm{q}, J=$ $35.6 \mathrm{~Hz}), 66.0,14.7$.

IR $v_{\max } 3282(\mathrm{w}), 2987(\mathrm{w}), 2895(\mathrm{w}), 1610(\mathrm{w}), 1534(\mathrm{~s}), 1454(\mathrm{w}), 1351(\mathrm{~s}), 1313(\mathrm{~m}), 1276$ (m), 1169 (s), 1109 (s), 1065 (s), 936 (m), 856 (m).

\section{2,2,2-Trifluoro-1-((methoxycarbonyl)amino)ethyl acetate (2i)}

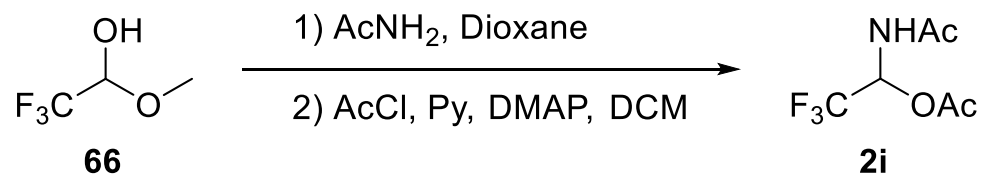

Following a slightly modified procedure, ${ }^{20}$ a $25 \mathrm{~mL}$ round-bottom flask was charged with acetamide (1.18 g, $20.0 \mathrm{mmol})$, 2,2,2-trifluoro-1-methoxyethanol (66) (2.56 mL, $22.0 \mathrm{mmol}, 1.1$ equiv), $4 \AA \mathrm{MS}(3 \mathrm{~g})$ and dioxane $(10 \mathrm{~mL})$ and then sealed under nitrogen atmosphere. The resulting mixture was heated at $100{ }^{\circ} \mathrm{C}$ for $5 \mathrm{~d}$. The mixture was filtered over Celite and the cake was washed with ethylacetate. The volatiles were removed under reduced pressure. The residue was dried under a nitrogen flow overnight. DCM $(40 \mathrm{~mL})$ was added and heated to reflux. The

\footnotetext{
18 The molecule ion could not be observed by high resolution mass spectrometry.

${ }^{19}$ Kumadaki, I.; Jonoshita, S.; Harada, A.; Omote, M.; Ando, A. J. Fluorine Chem. 1999, 97, 61

20 Tanaka, K.; Ishiguro, Y.; Mitsuhashi, K. Bull. Chem. Soc. Jpn. 1993, 66, 661.
} 
mixture was filtered. The mother liquor was concentrated to half its volume and filtered again. The solids were combined affording $N$-(2,2,2-trifluoro-1-hydroxyethyl)acetamide $(1.51 \mathrm{~g}, 9.61$ mmol, $48 \%$ ) as a white solid.

Acetyl chloride (1.8 mL, $26 \mathrm{mmol}, 4$ equiv) was slowly added to a solution of pyridine ( $2.3 \mathrm{~mL}$, $29 \mathrm{mmol}, 4.5$ equiv) and DMAP (39 $\mathrm{mg}, 0.32 \mathrm{mmol}, 5 \mathrm{~mol} \%)$ in dichloromethane (50 $\mathrm{mL})$ at 0 ${ }^{\circ} \mathrm{C}$. To the resulting mixture was added $\mathrm{N}-(2,2,2$-trifluoro-1-hydroxyethyl)acetamide (1.00 g, $6.37 \mathrm{mmol})$ portionwise. Then the mixture was stirred at $0{ }^{\circ} \mathrm{C}$ for $20 \mathrm{~min}$ and quenched with water $(10 \mathrm{~mL})$. The $\mathrm{pH}$ was adjusted to 2 by addition of $0.1 \mathrm{~N} \mathrm{HCl}$ and the layers were separated. The organic layer was washed with $0.1 \mathrm{~N} \mathrm{HCl}(3 \times 20 \mathrm{~mL})$ and brine $(30 \mathrm{~mL})$, dried over $\mathrm{MgSO}_{4}$, filtered and concentrated under reduced pressure. The crude residue was recrystallized in DCM to afford the title compound $\mathbf{2 i}(860 \mathrm{mg}, 4.32 \mathrm{mmol}, 68 \%)$ as a white solid.

m.p.: $123-126^{\circ} \mathrm{C}$.

${ }^{1} \mathbf{H}$ NMR (400 MHz, Chloroform- $d$ ) $\delta 7.00\left(\mathrm{dq}, J=10.4,5.3 \mathrm{~Hz}, 1 \mathrm{H}, \mathrm{CF}_{3} \mathrm{CH}\right.$ ), $6.44-6.33(\mathrm{~m}$, 1H, NH), 2.14 (s, 3H, OAc), 2.09 (s, 3H, NAc).

${ }^{13}$ C NMR $\left(101 \mathrm{MHz}, \mathrm{CDCl}_{3}\right) \delta 169.5,167.9,121.9(\mathrm{q}, J=280.9 \mathrm{~Hz}), 69.8(\mathrm{q}, J=36.8 \mathrm{~Hz}), 23.2$, 20.5 .

IR $v_{\max } 3280$ (m), 3058 (w), 1759 (s), 1680 (s), 1545 (m), 1433 (w), 1382 (m), 1259 (s), 1219 (s), $1164(\mathrm{~s}), 1050(\mathrm{~m}), 978(\mathrm{~m}), 914(\mathrm{w})$.

HRMS (ESI) calcd for $\mathrm{C}_{6} \mathrm{H}_{8} \mathrm{~F}_{3} \mathrm{NNaO}_{3}[\mathrm{M}+\mathrm{Na}] 222.0354$; found 222.0359. 


\section{Preparation of bromoalkynes.}

\section{General procedure for the bromination of terminal alkynes: ${ }^{21}$}

The terminal alkyne (1.0 equiv) is dissolved in acetone (ca. $6.8 \mathrm{~mL}$ per mmol of alkyne). Nbromosuccinimide (1.2 equiv) and $\mathrm{AgNO}_{3}$ (0.1 equiv) are added to the resulting solution in this order and the mixture is stirred at rt for 3-6 hours, until complete consumption of the starting material according to TLC. It was then poured onto iced water. The aqueous layer was extracted with pentane (3 times) and the combined organic extracts were dried over $\mathrm{MgSO}_{4}$, filtered and the solvent removed by evaporation under reduced pressure. The bromo alkyne was isolated by column chromatography in $95-99 \%$ purity as judged by ${ }^{1} \mathrm{H}$ NMR.

\section{2-Bromo-1-triisopropylsilyl acetylene (3)}

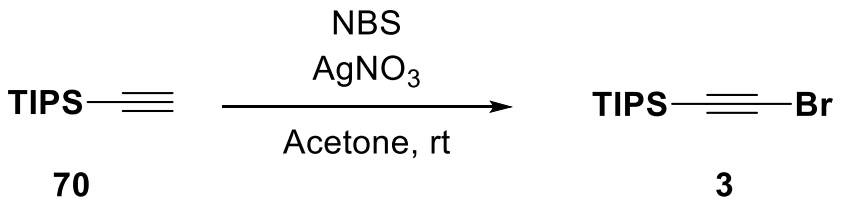

Triisopropylsilylacetylene (70) (813 $\mathrm{mg}, 4.45 \mathrm{mmol}, 1.00$ equiv) was brominated according to the general procedure. Bromoalkyne 3 was obtained as a colorless oil (1.16 g, 4.43 mmol, 99\%) without further purification.

${ }^{1} \mathbf{H}$ NMR $\left(400 \mathrm{MHz}, \mathrm{CDCl}_{3}\right) \delta 1.20-0.97$ (m, $\left.21 \mathrm{H}, \mathrm{TIPS}\right)$.

${ }^{13}$ C NMR $\left(100 \mathrm{MHz} \mathrm{CDCl}_{3}\right) \delta 83.5,61.7,18.5,11.3$.

Spectra data was consistent with the values reported in literature. ${ }^{21}$

\section{((4-Bromo-2-methylbut-3-yn-2-yl)oxy)triisopropylsilane (73)}

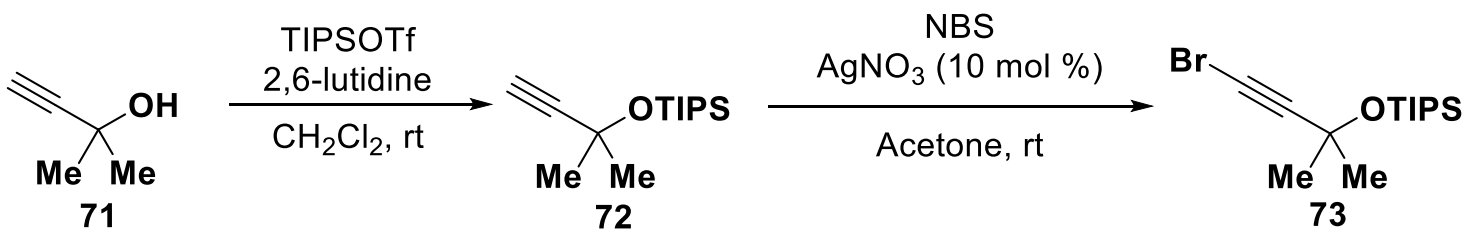

Following a reported procedure, ${ }^{22}$ 2-methylbut-3-yn-2-ol (71) $(0.34 \mathrm{~mL}, 3.5 \mathrm{mmol}, 1.0$ equiv.) and 2,6-lutidine (freshly distilled on $\mathrm{CaH}_{2}, 0.41 \mathrm{~mL}, 3.5 \mathrm{mmol}, 1.0$ equiv.) were dissolved in $\mathrm{CH}_{2} \mathrm{Cl}_{2}(12 \mathrm{~mL})$. TIPSOTf ( $0.94 \mathrm{~mL}, 3.5 \mathrm{mmol}, 1.0$ equiv.) was added dropwise to the solution at $0{ }^{\circ} \mathrm{C}$. The solution was allowed to warm to $\mathrm{rt}$ overnight and then quenched with a saturated aqueous $\mathrm{NaHCO}_{3}$ solution and the aqueous layer was extracted with $\mathrm{CH}_{2} \mathrm{Cl}_{2}(3 \times 10 \mathrm{~mL})$. The combined organic layers were washed with $\mathrm{H}_{2} \mathrm{O}$, dried over $\mathrm{MgSO}_{4}$, filtered and the solvent was removed in vacuo. Purification by column chromatography $\left(\mathrm{SiO}_{2}\right.$, pentane) afforded TIPSprotected propargyl alcohol 72 as a colorless oil (622 mg, $2.59 \mathrm{mmol}, 74 \%$ yield), which was used directly for the next step.

Following a reported procedure, ${ }^{6}$ propargyl alcohol 72 (603 mg, $2.51 \mathrm{mmol}, 1.0$ equiv) was dissolved in acetone $(17 \mathrm{~mL})$. N-bromosuccinimide $(535 \mathrm{mg}, 3.01 \mathrm{mmol}, 1.2$ equiv) and

${ }^{21}$ Jiang, M. X.; Rawat, M.; Wulff, W. D. J. Am. Chem. Soc., 2004, 126, 5970.

${ }^{22}$ Nishimura, T.; Nagaosa, M.; Hayashi, T. Tetrahedron Lett. 2011, 52, 2185. 
$\mathrm{AgNO}_{3}$ (42 mg, $0.25 \mathrm{mmol}, 0.1$ equiv) are added to the resulting solution in this order and the mixture is stirred at $\mathrm{rt}$ for 6 hours, until complete consumption of the starting material according to TLC. It was then poured onto iced water. The aqueous layer was extracted with pentane (3 times) and the combined organic extracts were dried over $\mathrm{MgSO}_{4}$, filtered and the solvent removed by evaporation under reduced pressure. After purification by column chromatography $\left(\mathrm{SiO}_{2}\right.$, pentane), bromoalkyne 73 was obtained as a colorless oil $(733 \mathrm{mg}, 2.30 \mathrm{mmol}, 91 \%$ yield).in $95 \%$ purity as judged by ${ }^{1} \mathrm{H}$ NMR.

${ }^{1} \mathbf{H}$ NMR $\left(400 \mathrm{MHz}, \mathrm{CDCl}_{3}\right) \delta 1.51(\mathrm{~s}, 6 \mathrm{H}), 1.18-1.03(\mathrm{~m}, 21 \mathrm{H})$.

${ }^{13}$ C NMR $\left(100 \mathrm{MHz}_{2} \mathrm{CDCl}_{3}\right) \delta 85.4,67.2,42.7,32.9,18.3,13.0$.

Spectra data was consistent with the values reported in literature. Error! Bookmark not defined.

\section{(((4-Bromo-2-methylbut-3-yn-2-yl)oxy)methyl)benzene (75)}
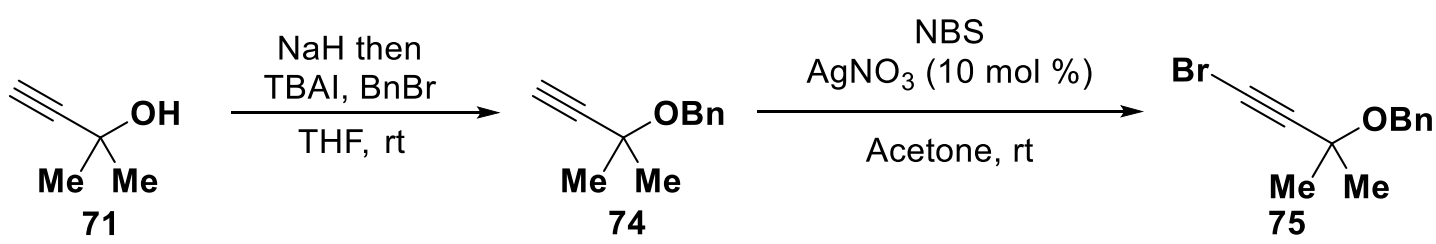

Following a reported procedure, ${ }^{23} \mathrm{NaH}$ (60\% suspension in mineral oil, $240 \mathrm{mg}, 6.00 \mathrm{mmol}, 1.2$ equiv) was added portionwise to a solution of 2-methyl-3-butyn-2-ol (71) (0.49 mL, $5.0 \mathrm{mmol}$, 1.0 equiv) in THF ( $24 \mathrm{~mL})$. The mixture was stirred at $\mathrm{rt}$ for 1 hour and then TBAI $(92.0 \mathrm{mg}$, $0.250 \mathrm{mmol}, 0.050$ equiv) and benzyl bromide $(0.72 \mathrm{~mL}, 6.0 \mathrm{mmol}, 1.2$ equiv) were added in this order. The reaction mixture was stirred at $\mathrm{rt}$ overnight and then diluted with $\mathrm{Et}_{2} \mathrm{O}(18 \mathrm{~mL})$. The organic solution was washed with water $(3 \times 15 \mathrm{~mL})$, brine and dried over $\mathrm{MgSO}_{4}$. Upon filtration, it was concentrated by evaporation under reduced pressure and the resulting crude oil was purified by column chromatography $\left(\mathrm{SiO}_{2}\right.$, Pentane/Et $\left.2 \mathrm{O} 95 / 5\right)$ to afford the pure Obenzylated alcohol 74 as a colorless oil $(715 \mathrm{mg}, 4.10 \mathrm{mmol}, 82 \%$ yield) which was directly used in the next step.

O-Benzylated alcohol $74(523 \mathrm{mg}, 3.00 \mathrm{mmol})$ was brominated according to the general procedure. After purification by column chromatography ( $\mathrm{SiO}_{2}$, Pentane/EtOAc 98/2), bromoalkyne 75 was obtained as a pale yellow oil $(631 \mathrm{mg}, 2.49 \mathrm{mmol}, 83 \%$ yield $)$.

${ }^{1}$ H NMR $\left(400 \mathrm{MHz}, \mathrm{CDCl}_{3}\right) \delta$ 7.41-7.31 (m, $\left.4 \mathrm{H}\right), 7.27(\mathrm{~m}, 1 \mathrm{H}), 4.62(\mathrm{~s}, 2 \mathrm{H}), 1.55(\mathrm{~s}, 6 \mathrm{H})$.

${ }^{13}$ C NMR $\left(101 \mathrm{MHz}, \mathrm{CDCl}_{3}\right) \delta 138.7,128.3,127.7,127.4,82.4,71.7,66.7,44.1,28.7$.

Spectra data was consistent with the values reported in literature.Error! Bookmark not defined.

\section{((1-Bromonon-1-yn-3-yl)oxy)triisopropylsilane (78)}

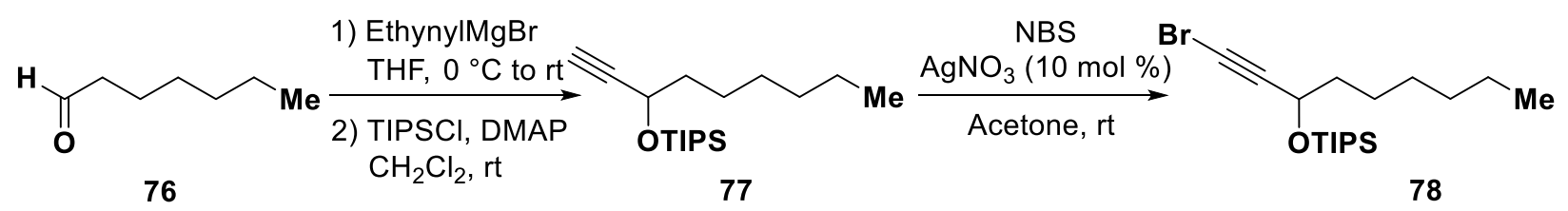

Following a slightly modified reported procedure, ${ }^{24}$ heptaldehyde (76) $(1.22 \mathrm{~mL}, 8.76 \mathrm{mmol}, 1.0$ equiv.) was added dropwise to a solution of ethynyl magnesium bromide (0.5 M in THF, 22.8

\footnotetext{
23 Trost, B. M.; Fandrick, D. R.; Dinh, D. C. J. Am. Chem. Soc. 2005, 127, 14186.

${ }^{24}$ Buzas, A.; Gagosz, F. J. Am. Chem. Soc. 2006, 128, 12614.
} 
$\mathrm{mL}, 11.4 \mathrm{mmol}, 1.3$ equiv.) at $0{ }^{\circ} \mathrm{C}$. After $30 \mathrm{~min}$, the cooling bath was removed to reach $\mathrm{rt}$ and the solution was stirred for further $2 \mathrm{~h}$. The reaction was then quenched by addition of aqueous $\mathrm{HCl}(1.0 \mathrm{M}, 15 \mathrm{~mL})$ and the mixture was extracted with $\mathrm{Et}_{2} \mathrm{O}(3 \times 20 \mathrm{~mL})$. The combined organic layers were washed with brine, dried over $\mathrm{MgSO}_{4}$, filtered and the solvent was removed under reduced pressure. Purification by column chromatography $\left(\mathrm{SiO}_{2}\right.$, pentane/EtOAc 20/1) afforded the corresponding propargyl alcohol as a yellow oil (943 mg, $6.73 \mathrm{mmol}, 77 \%$ yield).

TIPSCl (1.36 mL, $6.36 \mathrm{mmol}, 1.1$ equiv.) and DMAP (777 mg, $6.36 \mathrm{mmol}, 1.1$ equiv.) were dissolved in $\mathrm{CH}_{2} \mathrm{Cl}_{2}(10 \mathrm{~mL})$ at $\mathrm{rt}$ and a solution of propargyl alcohol $(810 \mathrm{mg}, 5.78 \mathrm{mmol}, 1.0$ equiv.) in $\mathrm{CH}_{2} \mathrm{Cl}_{2}(30 \mathrm{~mL})$ was slowly added to the reaction mixture. The reaction was stirred overnight and then quenched by sequential addition of $\mathrm{H}_{2} \mathrm{O}(36 \mathrm{~mL})$ and aqueous $\mathrm{HCl}(2.0 \mathrm{M}, 36$ $\mathrm{mL})$. The mixture was extracted with $\mathrm{CH}_{2} \mathrm{Cl}_{2}(3 \times 20 \mathrm{~mL})$ and the combined organic layers were washed with brine, dried over $\mathrm{MgSO}_{4}$, filtered and the solvent was removed in vacuo. Purification by column chromatography $\left(\mathrm{SiO}_{2}\right.$, Pentane) afforded the $O$-silylated propargyl alcohol 77 as a colorless oil (1.04 g, $3.51 \mathrm{mmol}, 61 \%$ yield).

O-Silylated propargyl alcohol 77 (890 mg, $3.00 \mathrm{mmol}, 1.0$ equiv.) was brominated according to the general procedure. After purification by column chromatography $\left(\mathrm{SiO}_{2}\right.$, pentane), bromo alkyne $\mathbf{7 8}$ was obtained as a colorless oil (1.04 g, $2.77 \mathrm{mmol}, 92 \%$ yield).

${ }^{1} \mathbf{H}$ NMR $\left(400 \mathrm{MHz}, \mathrm{CDCl}_{3}\right) \delta 4.48(\mathrm{t}, 1 \mathrm{H}, J=6.3 \mathrm{~Hz}), 1.69(\mathrm{~m}, 2 \mathrm{H}), 1.44(\mathrm{~m}, 2 \mathrm{H}), 1.36-1.26$ $(\mathrm{m}, 6 \mathrm{H}), 1.17-1.04(\mathrm{~m}, 21 \mathrm{H}), 0.89(\mathrm{t}, J=6.7 \mathrm{~Hz})$.

${ }^{13} \mathrm{C}$ NMR $\left(101 \mathrm{MHz}, \mathrm{CDCl}_{3}\right) \delta$ 82.1, 64.0, 43.6, 38.7, 31.8, 29.0, 24.9, 22.6, 18.0, 18.0, 14.1, 12.3.

Spectra data was consistent with the values reported in literature.Error! Bookmark not defined.

\section{((4-Bromo-1,1,1-trifluoro-2-phenylbut-3-yn-2-yl)oxy)(tert-butyl)dimethylsilane $(81)^{18}$}

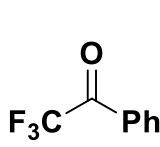

79

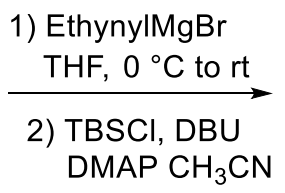

DMAP $\mathrm{CH}_{3} \mathrm{CN}$

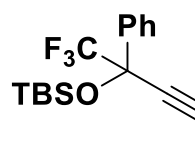

80

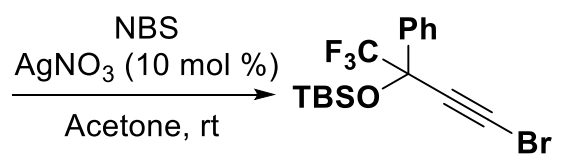

81

To a $0.5 \mathrm{M}$ solution of ethynylmagnesium bromide $(7.0 \mathrm{~mL}, 3.5 \mathrm{mmol})$ in THF was slowly added 2,2,2-trifluoro-1-phenylethanone (79) $(300 \mathrm{mg}, 1.72 \mathrm{mmol})$ in THF (1 mL). After $3 \mathrm{~h}$ at $\mathrm{rt}$ the reaction mixture was quenched with water $(1 \mathrm{~mL})$ and then $\mathrm{NH}_{4} \mathrm{Cl}$ sat solution was added $(5 \mathrm{~mL})$ and the mixture was diluted with DCM $(10 \mathrm{~mL})$. The layers were separated and the aqueous layer was extracted once with DCM $(10 \mathrm{~mL})$. The combined organic layers were dried over $\mathrm{MgSO}_{4}$, filtered and concentrated under reduced pressure to afford a yellow oil that was engaged in the next step without further purification.

TBS-Cl (0.422 g, $2.80 \mathrm{mmol}, 1.4$ equiv) was slowly added to a solution of the alcohol $(0.400 \mathrm{~g}$, $2.00 \mathrm{mmol}), \mathrm{DBU}(0.452 \mathrm{~mL}, 3.00 \mathrm{mmol}, 1.5$ equiv), DMAP (12 mg, $0.10 \mathrm{mmol}, 0.05$ equiv) in acetonitrile $(6 \mathrm{~mL})$ at $0{ }^{\circ} \mathrm{C}$. The reaction mixture was stirred for $12 \mathrm{~h}$ at $\mathrm{rt}$. The reaction mixture was quenched with water $(5 \mathrm{~mL})$ and extracted with DCM $(3 \times 5 \mathrm{~mL})$. The combined organic layers were dried over $\mathrm{MgSO}_{4}$, filtered and concentrated under reduced pressure. The crude residue was purified by column chromatography $\left(\mathrm{SiO}_{2}\right.$, Pentane) to afford compound $\mathbf{8 0}(0.460 \mathrm{~g}$, $1.46 \mathrm{mmol}, 73 \%$ yield) as a clear oil that was directly engaged in the next step. 
$O$-Silylated propargyl alcohol 80 (450 $\mathrm{mg}, 1.43 \mathrm{mmol}, 1.0$ equiv.) was brominated according to the general procedure. After purification by column chromatography ( $\mathrm{SiO}_{2}$, pentane), bromo alkyne 81 was obtained as a colorless oil (531 $\mathrm{mg}, 1.35 \mathrm{mmol}, 94 \%$ yield).

$\mathbf{R}_{\mathbf{f}} 0.6$ (pentane).

${ }^{1} \mathbf{H}$ NMR $\left(400 \mathrm{MHz}, \mathrm{CDCl}_{3}\right) \delta 7.76-7.64(\mathrm{~m}, 2 \mathrm{H}, \mathrm{ArH}), 7.46-7.34(\mathrm{~m}, 3 \mathrm{H}, \mathrm{ArH}), 0.98(\mathrm{~s}, 9 \mathrm{H}$, $t$ - $\mathrm{Bu}), 0.25$ (s, 3H, Me), 0.03 (s, 3H, Me).

${ }^{13}$ C NMR $\left(101 \mathrm{MHz}, \mathrm{CDCl}_{3}\right) \delta 136.9,129.5,128.1,127.5,123.1$ (q, J=286.3 Hz), 76.7, 75.4 (q, $J=32.5 \mathrm{~Hz}), 51.2,25.9,18.5,-3.4,-3.4$.

IR $v_{\max } 2955(\mathrm{w}), 2860(\mathrm{w}), 2207(\mathrm{w}), 1473(\mathrm{w}), 1264(\mathrm{~m}), 1179$ (s), $1146(\mathrm{~m}), 1081(\mathrm{~s}), 942$ (m), 863 (s), 841 (s). 


\section{Pd-catalyzed tandem aminal formation carbo-amination of allylamines.}

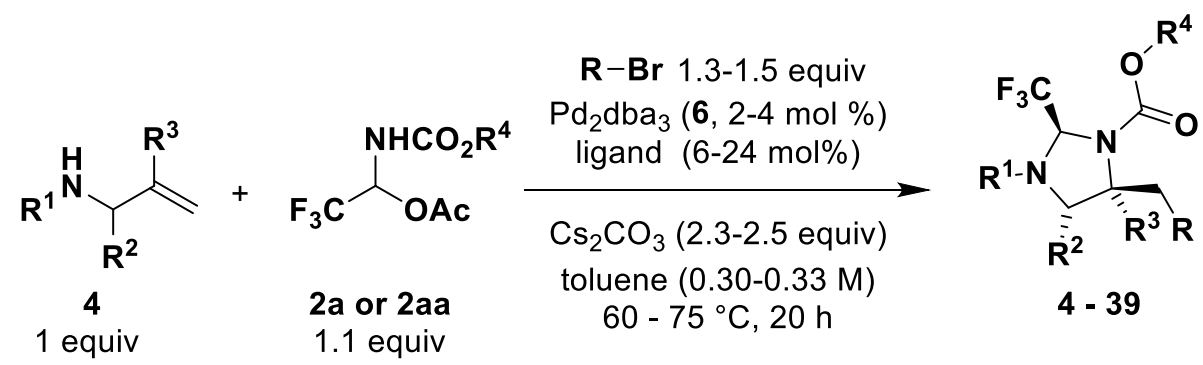

\section{General procedure A}

To an oven-dried $5 \mathrm{~mL}$ microwave tube under nitrogen atmosphere was added the aldimine ( $0.330 \mathrm{mmol}, 1.1$ equiv) and cesium carbonate $(225 \mathrm{mg}, 0.690 \mathrm{mmol}, 2.3$ equiv). The tube was sealed evacuated and backfilled with nitrogen (this was repeated for a total of 3 times). Then dry degassed toluene was added $(0.45 \mathrm{~mL})$ followed by allylamine $(0.300 \mathrm{mmol}, 1.00$ equiv $)$. The resulting mixture was stirred for $30 \mathrm{~min}$ at $70{ }^{\circ} \mathrm{C}$. Then (bromoethynyl)triisopropylsilane (3) (102 $\mathrm{mg}, 0.390 \mathrm{mmol})$ was added and a premixed solution of $\mathrm{Pd}_{2} \mathrm{dba}_{3}(5.5 \mathrm{mg}, 6.0 \mu \mathrm{mol})$ and Tri(2furyl)phosphine $(8.4 \mathrm{mg}, 0.036 \mathrm{mmol})$ in toluene $(0.45 \mathrm{~mL})$. The resulting mixture was stirred for $20 \mathrm{~h}$ at $60-70{ }^{\circ} \mathrm{C}$ in an oil bath, then cooled down, filtered over Celite eluting with Et2O and concentrated under reduced pressure to half its volume and directly purified by column chromatography using the indicated solvents.

\section{General procedure B for $\alpha$-branched allylamines}

To an oven-dried $5 \mathrm{~mL}$ microwave tube under nitrogen atmosphere was added the aldimine ( $0.330 \mathrm{mmol}, 1.1$ equiv), CsOTf (102 mg, $0.360 \mathrm{mmol}, 1.2$ equiv) and cesium carbonate (225 $\mathrm{mg}, 0.690 \mathrm{mmol}, 2.3$ equiv). The tube was sealed, evacuated and backfilled with nitrogen (this was repeated for a total of 3 times $)$. Then dry degassed toluene was added $(0.45 \mathrm{~mL})$ followed by allylamine (0.300 mmol, 1.00 equiv). The resulting mixture was stirred for 1 to $4 \mathrm{~h}$ at $70{ }^{\circ} \mathrm{C}$. Then (bromoethynyl)triisopropylsilane (3) $(102 \mathrm{mg}, 0.390 \mathrm{mmol})$ was added and a premixed solution of $\mathrm{Pd}_{2} \mathrm{dba}_{3}(11 \mathrm{mg}, 12 \mu \mathrm{mol})$ and Tri(2-furyl)phosphine (17 mg, $0.072 \mathrm{mmol}$ ) in toluene $(0.45 \mathrm{~mL})$. The resulting mixture was stirred for $20 \mathrm{~h}$ at $70{ }^{\circ} \mathrm{C}$ in an oil bath, then cooled down, filtered over Celite eluting with $\mathrm{Et}_{2} \mathrm{O}$ and concentrated under reduced pressure to half its volume and directly purified by column chromatography using the indicated solvents.

\section{General procedure $\mathbf{C}$ for 1,1-disubstituted olefins}

To an oven-dried $5 \mathrm{~mL}$ microwave tube under nitrogen atmosphere was added the aldimine and cesium carbonate ( $225 \mathrm{mg}, 0.690 \mathrm{mmol}, 2.3$ equiv). The tube was sealed, evacuated and backfilled with nitrogen (this was repeated for a total of 3 times). Then dry degassed toluene was added $(0.45 \mathrm{~mL})$ followed by allylamine $(0.300 \mathrm{mmol}, 1.00$ equiv). The resulting mixture was stirred for 1 to $4 \mathrm{~h}$ at $70{ }^{\circ} \mathrm{C}$. Then the bromo derivative was added and a premixed solution of $\mathrm{Pd}_{2} \mathrm{dba}_{3}(11 \mathrm{mg}, 12 \mu \mathrm{mol})$ and $\mathrm{PhDavePhos}(23 \mathrm{mg}, 0.060 \mathrm{mmol})$ in toluene $(0.45 \mathrm{~mL})$. The resulting mixture was stirred for $20 \mathrm{~h}$ at $70{ }^{\circ} \mathrm{C}$ in an oil bath, then cooled down, filtered over Celite eluting with $\mathrm{Et}_{2} \mathrm{O}$ and concentrated under reduced pressure to half its volume and directly purified by column chromatography using the indicated solvents. 
General procedure D for aryl and vinyl bromides

To an oven-dried $5 \mathrm{~mL}$ microwave tube under nitrogen atmosphere was added the aldimine ( $0.330 \mathrm{mmol}, 1.1$ equiv), CsOTf (102 $\mathrm{mg}, 0.360 \mathrm{mmol}, 1.2$ equiv) and cesium carbonate (239 $\mathrm{mg}, 0.735 \mathrm{mmol}, 2.45$ equiv). The tube was sealed, evacuated and backfilled with nitrogen (this was repeated for a total of 3 times). Then dry degassed toluene was added $(0.50 \mathrm{~mL})$ followed by allylamine $\left(0.300 \mathrm{mmol}, 1.00\right.$ equiv). The resulting mixture was stirred for $30 \mathrm{~min}$ at $70{ }^{\circ} \mathrm{C}$. Then the aryl or vinyl bromide $\left(0.450 \mathrm{mmol}, 1.5\right.$ equiv) was added and a premixed solution of $\mathrm{Pd}_{2} \mathrm{dba}_{3}$ $(11 \mathrm{mg}, 12 \mu \mathrm{mol})$ and Tri $(2$-furyl)phosphine $(17 \mathrm{mg}, 0.072 \mathrm{mmol})$ in toluene $(0.50 \mathrm{~mL})$. The resulting mixture was stirred for $20 \mathrm{~h}$ at $70^{\circ} \mathrm{C}$ in an oil bath, then cooled down, filtered over Celite eluting with $\mathrm{Et}_{2} \mathrm{O}$ and concentrated under reduced pressure to half its volume and directly purified by column chromatography using the indicated solvents.

$N B$ : when a solid aryl bromide was used, it was added in solution in toluene.

The stereochemistry of the imidazolidines was assigned by analogy with compounds 16, 19 and 22 for which 2D ROESY and 1D NOESY experiments were performed.

Tert-butyl 3-benzyl-2-(trifluoromethyl)-5-(3-(triisopropylsilyl)prop-2-yn-1-yl)imidazolidine1-carboxylate (4)

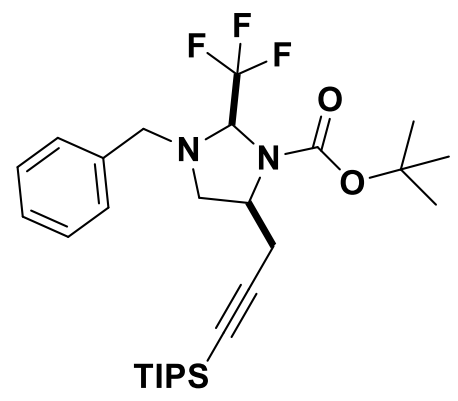

Following General Procedure A, the title compound was prepared from N-benzylprop-2-en-1-amine (1) $(44.2 \mathrm{mg}, 0.300 \mathrm{mmol}), 1$ ((tert-butoxycarbonyl)amino)-2,2,2-trifluoroethyl acetate (2a) (85 $\mathrm{mg}, 0.33 \mathrm{mmol}, 1.1$ equiv) and (bromoethynyl)triisopropylsilane (3) $(102 \mathrm{mg}, 0.390 \mathrm{mmol}, 1.3$ equiv). The crude oil was purified by column chromatography on Biotage (SNAP cartridge KP-SIL $25 \mathrm{~g}$, 92:8 to 40:60 Pentane: $\mathrm{CH}_{2} \mathrm{Cl}_{2}$ ) affording the title compound 4 (150 $\mathrm{mg}, 0.286 \mathrm{mmol}, 95 \%$ yield, $d r>20: 1$ in the crude ${ }^{19} \mathrm{~F} \mathrm{NMR}$ ) as a

pale yellow oil.

$\mathbf{R}_{\mathbf{f}} 0.40\left(\right.$ Pentane $\left./ \mathrm{CH}_{2} \mathrm{Cl}_{2} 2 / 1\right)$.

${ }^{1} \mathbf{H}$ NMR $\left(400 \mathrm{MHz}, \mathrm{CDCl}_{3}\right) \delta 7.39-7.28(\mathrm{~m}, 5 \mathrm{H}, \mathrm{ArH}), 5.11-4.74\left(\mathrm{~m}, 1 \mathrm{H}, \mathrm{CHCF}_{3}\right), 4.16-$ $3.90(\mathrm{~m}, 1 \mathrm{H}, \mathrm{CHN}), 3.90-3.77\left(\mathrm{~m}, 2 \mathrm{H}, \mathrm{PhCH}_{2}\right), 3.27\left(\mathrm{app} \mathrm{d}, J=7.5,2 \mathrm{H}, \mathrm{CH}_{2} \mathrm{~N}\right), 3.00(\mathrm{bs}, 1 \mathrm{H}$, $\left.\mathrm{CH}_{2} \mathrm{CC}\right), 2.30\left(\mathrm{dd}, J=16.4,10.5 \mathrm{~Hz}, 1 \mathrm{H}, \mathrm{CH}_{2} \mathrm{CC}\right), 1.49$ (s, 9H, Boc), $1.07-0.99(\mathrm{~m}, 21 \mathrm{H}$, TIPS).

${ }^{13}$ C NMR $\left(101 \mathrm{MHz}, \mathrm{CDCl}_{3}\right) \delta 154.2,137.2,128.9,128.7,128.0,124.3$ (q, $\left.J=284.4 \mathrm{~Hz}\right), 104.4$, 82.6, 81.6, $77.4(\mathrm{q}, J=33.5 \mathrm{~Hz}), 60.0,57.1,56.1,28.3,25.1,18.7,11.3$.

${ }^{19} \mathbf{F}$ NMR $\left(376 \mathrm{MHz}, \mathrm{CDCl}_{3}\right) \delta-76.7$.

IR $v_{\max } 2942(\mathrm{~m}), 2867$ (m), $2175(\mathrm{w}), 1707$ (s), 1464 (w), 1375 (s), 1155 (s), $913(\mathrm{~m})$.

HRMS calcd for $\mathrm{C}_{28} \mathrm{H}_{44} \mathrm{~F}_{3} \mathrm{~N}_{2} \mathrm{O}_{2} \mathrm{Si}^{+}[\mathrm{M}+\mathrm{H}]^{+} 525.3119$; found 525.3119.

Methyl 3-benzyl-2-(trifluoromethyl)-5-(3-(triisopropylsilyl)prop-2-yn-1-yl)imidazolidine-1carboxylate (5)

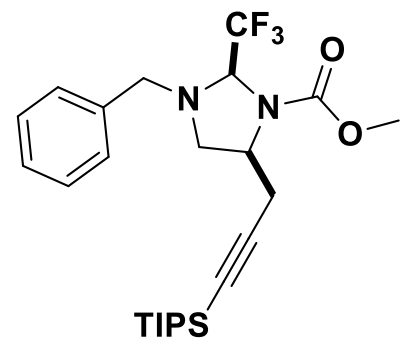

Following General Procedure A, the title compound was prepared from N-benzylprop-2-en-1-amine (1) $(44.2 \mathrm{mg}, 0.300 \mathrm{mmol}), 2,2,2-$ trifluoro-1-((methoxycarbonyl)amino)ethyl acetate (2aa) $(71 \mathrm{mg}, 0.33$ mmol, 1.1 equiv) and (bromoethynyl)triisopropylsilane (3) $(102 \mathrm{mg}$, 
$0.390 \mathrm{mmol}, 1.3$ equiv). The crude oil was purified by column chromatography $\left(\mathrm{SiO}_{2} 2: 1\right.$ Pentane: $\mathrm{CH}_{2} \mathrm{Cl}_{2}$ ) affording the title compound 5 (136 mg, $0.282 \mathrm{mmol}, 94 \%$ yield, $d r>20: 1$ in the crude ${ }^{19} \mathrm{~F}$ NMR) as a clear oil.

$\mathbf{R}_{\mathbf{f}} 0.20$ (Pentane/ $\left.\mathrm{CH}_{2} \mathrm{Cl}_{2} 2 / 1\right)$.

${ }^{1} \mathbf{H}$ NMR $\left(400 \mathrm{MHz}, \mathrm{CDCl}_{3}\right) \delta 7.39-7.27$ (m, 5H, ArH), $5.15-4.77$ (m, 1H, CHCF $)$, 4.06$3.93(\mathrm{~m}, 1 \mathrm{H}, \mathrm{CHN}), 3.87\left(\mathrm{~d}, J=13.2 \mathrm{~Hz}, 1 \mathrm{H}, \mathrm{PhCH}_{2}\right), 3.79\left(\mathrm{~d}, J=13.2 \mathrm{~Hz}, 1 \mathrm{H}, \mathrm{CH} \mathrm{H}_{2} \mathrm{Ph}\right), 3.75(\mathrm{~s}$, $3 \mathrm{H}, \mathrm{CH}_{3} \mathrm{O}$ ), 3.26 (app. dd, $\left.J=7.7,1.6 \mathrm{~Hz}, 2 \mathrm{H}, \mathrm{CH}_{2} \mathrm{~N}\right), 2.97\left(\mathrm{~m}, 1 \mathrm{H}, \mathrm{CH}_{2} \mathrm{CC}\right), 2.31$ (dd, $J=16.4$, $\left.10.5 \mathrm{~Hz}, 1 \mathrm{H}, \mathrm{CH}_{2} \mathrm{CC}\right), 1.31-0.80$ (m, 21H, TIPS).

${ }^{13}$ C NMR (101 MHz, $\left.\mathrm{CDCl}_{3}\right) 155.6,137.1,128.9,128.7,128.0,124.1$ (q, $\left.J=284.3 \mathrm{~Hz}\right), 104.1$, 82.9, $77.5(\mathrm{~m}), 59.9,57.2,56.2,53.3,25.0,18.7,11.3$.

${ }^{19}$ F NMR $\left(376 \mathrm{MHz}^{\mathrm{CDCl}} \mathrm{CDC}_{3} \delta-76.7\right.$.

IR $v_{\max } 2949(\mathrm{~m}), 2866(\mathrm{~m}), 2175(\mathrm{w}), 1723$ (s), 1450 (m), 1360 (s), 1140 (s), 989 (m), $882(\mathrm{w})$.

HRMS calcd for $\mathrm{C}_{25} \mathrm{H}_{38} \mathrm{~F}_{3} \mathrm{~N}_{2} \mathrm{O}_{2} \mathrm{Si}^{+}[\mathrm{M}+\mathrm{H}]^{+} 483.2649$; found 483.2641.

\section{Methyl 2-(trifluoromethyl)-3-(4-(trifluoromethyl)benzyl)-5-(3-(triisopropylsilyl)prop-2-yn-} 1-yl)imidazolidine-1-carboxylate (6)

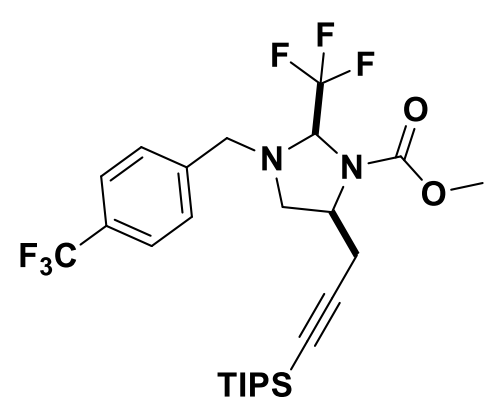

Following General Procedure A, the title compound was prepared from N-(4-(trifluoromethyl)benzyl)prop-2-en-1-amine (50) (64.6 $\mathrm{mg}, \quad 0.300 \quad \mathrm{mmol}), \quad 2,2,2$-trifluoro-1((methoxycarbonyl)amino)ethyl acetate (2aa) $(71 \mathrm{mg}, 0.33 \mathrm{mmol}$, 1.1 equiv) and (bromoethynyl)triisopropylsilane (3) $(102 \mathrm{mg}$, $0.390 \mathrm{mmol}, 1.3$ equiv). The crude oil was purified by column chromatography $\left(\mathrm{SiO}_{2} 2: 1\right.$ Pentane: $\mathrm{CH}_{2} \mathrm{Cl}_{2}$ ) affording the title compound 6 (156 mg, $0.283 \mathrm{mmol}, 94 \%$ yield, $d r>20: 1$ in the crude ${ }^{19} \mathrm{~F}$ NMR) as a pale yellow oil.

$\mathbf{R}_{\mathbf{f}} 0.50$ (Pentane/ $\left.\mathrm{CH}_{2} \mathrm{Cl}_{2} 1 / 1\right)$.

${ }^{1} \mathbf{H}$ NMR $\left(400 \mathrm{MHz}, \mathrm{CDCl}_{3}\right) \delta 7.60(\mathrm{~d}, J=8.1 \mathrm{~Hz}, 2 \mathrm{H}, \mathrm{ArH}), 7.46(\mathrm{~d}, J=8.0 \mathrm{~Hz}, 2 \mathrm{H}, \mathrm{ArH}), 5.02$ $-4.81\left(\mathrm{~m}, 1 \mathrm{H}, \mathrm{CHCF}_{3}\right), 4.23-4.04(\mathrm{~m}, 1 \mathrm{H}, \mathrm{CHN}), 3.97\left(\mathrm{~d}, J=13.3 \mathrm{~Hz}, 1 \mathrm{H}, \mathrm{ArCH}_{2}\right), 3.82(\mathrm{~d}, J$ $\left.=13.5 \mathrm{~Hz}, 1 \mathrm{H}, \mathrm{ArCH}_{2}\right), 3.77\left(\mathrm{~s}, 3 \mathrm{H}, \mathrm{CH}_{3} \mathrm{O}\right), 3.26\left(\mathrm{dd}, J=11.6,7.0 \mathrm{~Hz}, 1 \mathrm{H}, \mathrm{CH}_{2} \mathrm{~N}\right), 3.15(\mathrm{dd}, J=$ 11.6, $\left.7.7 \mathrm{~Hz}, 1 \mathrm{H}, \mathrm{CH}_{2} \mathrm{~N}\right), 3.06-2.87\left(\mathrm{~m}, 1 \mathrm{H}, \mathrm{CH}_{2} \mathrm{CC}\right), 2.35\left(\mathrm{dd}, J=16.4,10.5 \mathrm{~Hz}, 1 \mathrm{H}, \mathrm{CH} \mathrm{CC}_{2}\right.$, $1.09-0.95(\mathrm{~m}, 21 \mathrm{H}, \mathrm{TIPS})$.

${ }^{13}$ C NMR (101 MHz, Chloroform- $d$ ) $\delta 155.7,141.4,130.3(\mathrm{q}, J=32.4 \mathrm{~Hz}), 129.0,125.7(\mathrm{q}, J=$ $3.8 \mathrm{~Hz}), 124.4(\mathrm{q}, J=272.2 \mathrm{~Hz}), 124.2(\mathrm{q}, J=284.2 \mathrm{~Hz}), 104.0,83.2,77.5(\mathrm{~m}$, overlapping with chloroform signals), 59.2, 57.2, 56.2, 53.5, 25.0, 18.7, 11.3 .

${ }^{19}$ F NMR $\left(376 \mathrm{MHz}, \mathrm{CDCl}_{3}\right) \delta-62.6,-76.5$.

IR $v_{\max } 2960(\mathrm{~m}), 2871(\mathrm{~m}), 2175(\mathrm{w}), 1724(\mathrm{~s}), 1453(\mathrm{~m}), 1368(\mathrm{~m}), 1323(\mathrm{~s}), 1170$ (s), $1137(\mathrm{~s})$, 1074 (m).

HRMS calcd. for $\mathrm{C}_{26} \mathrm{H}_{37} \mathrm{~F}_{6} \mathrm{~N}_{2} \mathrm{O}_{2} \mathrm{Si}^{+}[\mathrm{M}+\mathrm{H}]^{+}$551.2523; found 551.2528. 


\section{Methyl 3-(4-formylbenzyl)-2-(trifluoromethyl)-5-(3-(triisopropylsilyl)prop-2-yn-1-}

yl)imidazolidine-1-carboxylate (7)

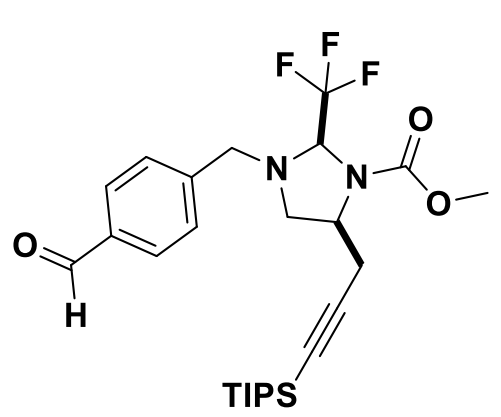

Following General Procedure A, the title compound was prepared from freshly purified 4((allylamino)methyl)benzaldehyde (52) $(52.6 \mathrm{mg}, 0.300 \mathrm{mmol})$, 2,2,2-trifluoro-1-((methoxycarbonyl)amino)ethyl acetate (2aa) (71 $\mathrm{mg}, \quad 0.33$ mmol, 1.1 equiv) and (bromoethynyl)triisopropylsilane (3) (102 $\mathrm{mg}, 0.390 \mathrm{mmol}, 1.3$ equiv). The crude oil was purified by column chromatography on Biotage (SNAP cartridge KP-SIL $25 \mathrm{~g}$, 60:40 to 0:100 Pentane: $\left.\mathrm{CH}_{2} \mathrm{Cl}_{2}\right)$ affording the title compound $7(142 \mathrm{mg}, 0.278$ mmol, 93\% yield, $d r>20: 1$ in the crude ${ }^{19} \mathrm{~F}$ NMR) as a yellow oil.

$\mathbf{R}_{\mathbf{f}} 0.25$ (Pentane/ $\mathrm{CH}_{2} \mathrm{Cl}_{2} 1 / 2$ ).

${ }^{1} \mathbf{H}$ NMR $\left(400 \mathrm{MHz}, \mathrm{CDCl}_{3}\right) \delta 10.0$ (s, 1H, CHO), $7.90-7.82(\mathrm{~m}, 2 \mathrm{H}, \mathrm{ArH}), 7.56-7.47(\mathrm{~m}, 2 \mathrm{H}$, $\operatorname{Ar} H), 5.07-4.78\left(\mathrm{~m}, 1 \mathrm{H}, \mathrm{CHCF}_{3}\right), 4.25-4.04(\mathrm{~m}, 1 \mathrm{H}, \mathrm{CHN}), 3.98\left(\mathrm{~d}, J=13.8 \mathrm{~Hz}, 1 \mathrm{H}, \mathrm{ArCH}_{2}\right)$, $3.86\left(\mathrm{~d}, J=13.8 \mathrm{~Hz}, 1 \mathrm{H}, \mathrm{ArCH}_{2}\right), 3.77\left(\mathrm{~s}, 3 \mathrm{H}, \mathrm{CH}_{3} \mathrm{O}\right), 3.28\left(\mathrm{dd}, J=11.9,7.2 \mathrm{~Hz}, 1 \mathrm{H}, \mathrm{CH}_{2} \mathrm{~N}\right)$, $3.17\left(\mathrm{dd}, J=11.9,7.3 \mathrm{~Hz}, 1 \mathrm{H}, \mathrm{CH}_{2} \mathrm{~N}\right), 3.10-2.85\left(\mathrm{~m}, 1 \mathrm{H}, \mathrm{CH}_{2} \mathrm{CC}\right), 2.35(\mathrm{dd}, J=16.4,10.5 \mathrm{~Hz}$, $\left.1 \mathrm{H}, \mathrm{CH}_{2} \mathrm{CC}\right), 0.99$ (m, 21H, TIPS).

${ }^{13}$ C NMR (101 MHz, Chloroform- $d$ ) $\delta 191.9,155.7,144.3,136.2,130.2,129.2,124.0$ (q, $J=$ $284.2 \mathrm{~Hz}$ ), 103.9, 83.2, 77.6 (m overlapping with chloroform signals), 59.5, 57.4, 56.2, 53.5, 25.0, 18.7, 11.3 .

${ }^{19} \mathbf{F}$ NMR $\left(376 \mathrm{MHz}, \mathrm{CDCl}_{3}\right) \delta-76.5$.

IR $v_{\max } 2948(\mathrm{w}), 2865(\mathrm{w}), 2176(\mathrm{w}), 1714(\mathrm{~s}), 1453(\mathrm{~m}), 1365$ (m), 1289 (m), 1176 (s), 1143 (s), $915(\mathrm{w})$.

HRMS calcd. for $\mathrm{C}_{26} \mathrm{H}_{37} \mathrm{~F}_{3} \mathrm{~N}_{2} \mathrm{NaO}_{3} \mathrm{Si}^{+}[\mathrm{M}+\mathrm{Na}]^{+}$533.2418; found 533.2425.

Methyl 3-(4-bromobenzyl)-2-(trifluoromethyl)-5-(3-(triisopropylsilyl)prop-2-yn-1yl)imidazolidine-1-carboxylate (8)

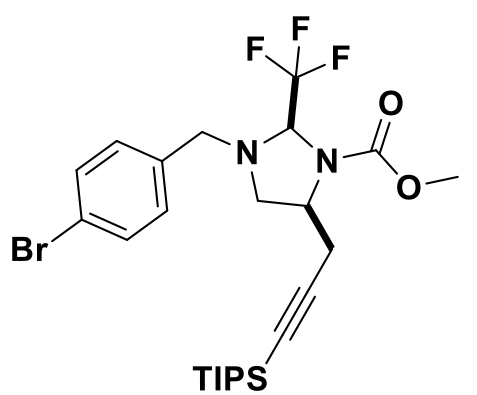

Following General Procedure A, the title compound was prepared from $\mathrm{N}$-(4-bromobenzyl)prop-2-en-1-amine (67.8 mg, $0.300 \mathrm{mmol})$, 2,2,2-trifluoro-1-((methoxycarbonyl)amino)ethyl acetate (2aa) (71 $\mathrm{mg}, 0.33 \mathrm{mmol}, 1.1$ equiv) and (bromoethynyl)triisopropylsilane (3) (102 $\mathrm{mg}, 0.390 \mathrm{mmol}, 1.3$ equiv). The crude oil was purified by column chromatography $\left(\mathrm{SiO}_{2} 5: 2\right.$ to 2:1 Pentane: $\left.\mathrm{CH}_{2} \mathrm{Cl}_{2}\right)$ affording the title compound $\mathbf{8}(148 \mathrm{mg}, 0.264 \mathrm{mmol}, 88 \%$ yield, $d r>20: 1$ in the crude ${ }^{19} \mathrm{~F} \mathrm{NMR}$ ) as a pale yellow oil.

$\mathbf{R}_{\mathbf{f}} 0.48$ (Pentane/ $\left.\mathrm{CH}_{2} \mathrm{Cl}_{2} 1 / 1\right)$.

${ }^{1} \mathbf{H}$ NMR $\left(400 \mathrm{MHz}, \mathrm{CDCl}_{3}\right) \delta 7.49-7.42(\mathrm{~m}, 2 \mathrm{H}, \mathrm{ArH}), 7.23-7.16(\mathrm{~m}, 2 \mathrm{H}, \mathrm{ArH}), 5.04-4.77$ $\left(\mathrm{m}, 1 \mathrm{H}, \mathrm{CHCF}_{3}\right), 4.22-3.97(\mathrm{~m}, 1 \mathrm{H}, \mathrm{CHN}), 3.83\left(\mathrm{~d}, J=13.6 \mathrm{~Hz}, 1 \mathrm{H}, \mathrm{ArCH}_{2}\right), 3.75(\mathrm{~s}, 3 \mathrm{H}$, $\left.\mathrm{CH}_{3} \mathrm{O}\right), 3.72\left(\mathrm{~d}, J=13.6 \mathrm{~Hz}, 1 \mathrm{H}, \mathrm{ArCH}_{2}\right), 3.25\left(\mathrm{dd}, J=12.1,7.3 \mathrm{~Hz}, 1 \mathrm{H}, \mathrm{CH}_{2} \mathrm{~N}\right), 3.17(\mathrm{dd}, J=$ $\left.12.1,7.3 \mathrm{~Hz}, 1 \mathrm{H}, \mathrm{CH}_{2} \mathrm{~N}\right), 3.03-2.87\left(\mathrm{~m}, 1 \mathrm{H}, \mathrm{CH}_{2} \mathrm{CC}\right), 2.32(\mathrm{dd}, J=16.4,10.4 \mathrm{~Hz}, 1 \mathrm{H}$, , $\left.\mathrm{CH}_{2} \mathrm{CC}\right), 1.10-0.93(\mathrm{~m}, 21 \mathrm{H}, \mathrm{TIPS})$.

${ }^{13}$ C NMR (101 MHz, Chloroform- $d$ ) $\delta$ 155.7, 136.2, 131.8, 130.4, 124.2 (q, $\left.J=283.9 \mathrm{~Hz}\right), 121.9$, 104.0, 83.1, 77.5 (m overlapping with chloroform signals), 59.1, 57.1, 56.1, 53.4, 25.0, 18.6, 11.3 . 
${ }^{19} \mathbf{F}$ NMR $\left(376 \mathrm{MHz}, \mathrm{CDCl}_{3}\right) \delta-76.6$.

IR $v_{\max } 2951(\mathrm{~m}), 2866(\mathrm{~m}), 2175(\mathrm{w}), 1719(\mathrm{~s}), 1448$ (s), 1364 (s), 1175 (s), 1143 (s).

HRMS calcd. for $\mathrm{C}_{25} \mathrm{H}_{37}{ }^{79} \mathrm{BrF}_{3} \mathrm{~N}_{2} \mathrm{O}_{2} \mathrm{Si}^{+}[\mathrm{M}+\mathrm{H}]^{+}$561.1754; found 561.1751.

\section{Methyl 3-(2-chlorobenzyl)-2-(trifluoromethyl)-5-(3-(triisopropylsilyl)prop-2-yn-1- yl)imidazolidine-1-carboxylate (9)}

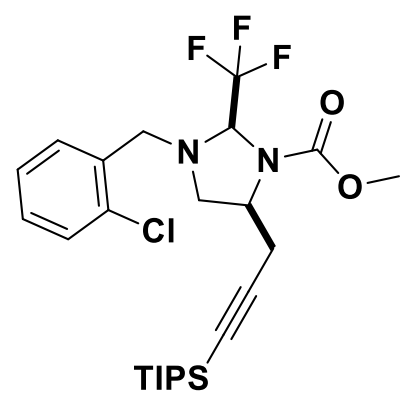

Following General Procedure A, the title compound was prepared from $\mathrm{N}$-(2-chlorobenzyl)prop-2-en-1-amine $(54.5 \mathrm{mg}, 0.300 \mathrm{mmol}$ ), 2,2,2-trifluoro-1-((methoxycarbonyl)amino)ethyl acetate (2aa) (71 $\mathrm{mg}, 0.33 \mathrm{mmol}, 1.1$ equiv) and (bromoethynyl)triisopropylsilane (3) (102 mg, $0.390 \mathrm{mmol} 1.3$ equiv). The crude oil ( $d r 16.5: 1$ in the crude ${ }^{19} \mathrm{~F}$ NMR) was purified by column chromatography on Biotage (SNAP cartridge KP-SIL $25 \mathrm{~g}, 92: 8$ to 40:60 Pentane: $\mathrm{CH}_{2} \mathrm{Cl}_{2}$ ) affording the title compound 9 (142 $\mathrm{mg}, 0.275 \mathrm{mmol}, 92 \%$ yield, $d r>20: 1$ in the ${ }^{19} \mathrm{~F}$ NMR) as a pale yellow oil.

$\mathbf{R}_{\mathbf{f}} 0.40$ (Pentane/ $\left.\mathrm{CH}_{2} \mathrm{Cl}_{2} 2 / 1\right)$.

${ }^{1} \mathbf{H}$ NMR $\left(400 \mathrm{MHz}, \mathrm{CDCl}_{3}\right) \delta 7.54-7.47(\mathrm{~m}, 1 \mathrm{H}, \mathrm{ArH}), 7.41-7.34(\mathrm{~m}, 1 \mathrm{H}, \mathrm{Ar} H), 7.31-7.21$ $(\mathrm{m}, 2 \mathrm{H}, \mathrm{ArH}), 5.13-4.84\left(\mathrm{~m}, 1 \mathrm{H}, \mathrm{CHCF}_{3}\right), 4.30-4.09(\mathrm{~m}, 1 \mathrm{H}, \mathrm{CHN}), 4.01(\mathrm{~d}, J=13.9 \mathrm{~Hz}, 1 \mathrm{H}$, $\left.\mathrm{ArCH}_{2}\right), 3.95\left(\mathrm{~d}, J=13.9 \mathrm{~Hz}, 1 \mathrm{H}, \mathrm{ArCH}_{2}\right), 3.79\left(\mathrm{~s}, 3 \mathrm{H}, \mathrm{CH}_{3} \mathrm{O}\right), 3.35-3.21\left(\mathrm{~m}, 2 \mathrm{H}, \mathrm{CH}_{2} \mathrm{~N}\right), 3.12$ $-2.92\left(\mathrm{~m}, 1 \mathrm{H}, \mathrm{CH}_{2} \mathrm{CC}\right), 2.35$ (dd, $\left.J=16.4,10.5 \mathrm{~Hz}, 1 \mathrm{H}, \mathrm{CH}_{2} \mathrm{CC}\right), 1.07-0.97$ (m, 21H, TIPS).

${ }^{13}$ C NMR (101 MHz, Chloroform- $d$ ) $\delta 155.7,134.9,134.1,130.7,129.7,129.1,127.1,124.0$ (q, $J=284.4 \mathrm{~Hz}), 104.0,83.0,78.0(\mathrm{q}, J=34.0 \mathrm{~Hz}), 57.2,56.4,56.1,53.4,24.9,18.6,11.3$.

${ }^{19} \mathbf{F}$ NMR $\left(376 \mathrm{MHz}, \mathrm{CDCl}_{3}\right) \delta-76.6$.

IR $v_{\max } 2944(\mathrm{w}), 2864(\mathrm{w}), 2175(\mathrm{w}), 1717(\mathrm{~s}), 1450(\mathrm{~m}), 1362(\mathrm{~s}), 1143$ (s), $911(\mathrm{~s})$.

HRMS calcd for $\mathrm{C}_{25} \mathrm{H}_{37} \mathrm{ClF}_{3} \mathrm{~N}_{2} \mathrm{O}_{2} \mathrm{Si}^{+}[\mathrm{M}+\mathrm{H}]^{+}$517.2259; found 517.2259.

Tert-butyl 3-(4-methoxybenzyl)-2-(trifluoromethyl)-5-(3-(triisopropylsilyl)prop-2-yn-1yl)imidazolidine-1-carboxylate (10)

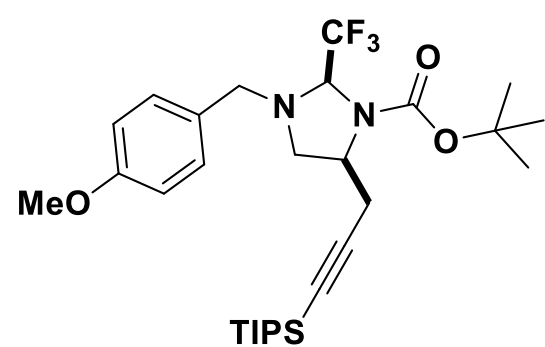

To an oven-dried $50 \mathrm{~mL}$ schlenk tube under nitrogen atmosphere was added degassed Toluene $(4.50 \mathrm{~mL}), \mathrm{N}-(4-$ methoxybenzyl)prop-2-en-1-amine $(0.532 \mathrm{~g}, 3.00 \mathrm{mmol})$ and 1-((tert-butoxycarbonyl)amino)-2,2,2-trifluoroethyl acetate (2a) $(0.849 \mathrm{~g}, 3.30 \mathrm{mmol}, 1.1$ equiv) and cesium carbonate $(2.15 \mathrm{~g}, 6.60 \mathrm{mmol}, 2.2$ equiv). The resulting mixture was stirred for $30 \mathrm{~min}$ at $70{ }^{\circ} \mathrm{C}$. Then (bromoethynyl)triisopropylsilane (3) $(1.019 \mathrm{~g}, 3.90 \mathrm{mmol}, 1.3$ equiv) was added followed by a premixed solution of $\mathrm{Pd}_{2}(\mathrm{dba})_{3}(55.0 \mathrm{mg}, 0.0600 \mathrm{mmol}, 2 \mathrm{~mol} \%)$ and tri(2-furyl)phosphine $(0.0836 \mathrm{~g}, 0.360 \mathrm{mmol}, 12 \mathrm{~mol} \%)$ in toluene $(4.50 \mathrm{~mL})$. The resulting mixture was stirred for $20 \mathrm{~h}$ at $60{ }^{\circ} \mathrm{C}$ in an oil bath, then cooled down, filtered over Celite eluting with $\mathrm{Et}_{2} \mathrm{O}$ and concentrated under reduced pressure. The crude residue (> 20:1 dr by integration of the propargylic peaks in the crude ${ }^{1} \mathrm{H}$ NMR)was purified by column chromatography on Biotage (SNAP cartridge KP-SIL $25 \mathrm{~g}$, 88:12 Pentane: $\mathrm{CH}_{2} \mathrm{Cl}_{2}$ to 35:65 Pentane: $\mathrm{CH}_{2} \mathrm{Cl}_{2}$ ) to afford the title compound 10 (1.65 g, $2.98 \mathrm{mmol}, 99 \%$ yield, $d r>20: 1$ in the ${ }^{1} \mathrm{H}$ NMR) as a yellow oil.

$\mathbf{R}_{\mathbf{f}} 0.20$ (Pentane/ $\left.\mathrm{CH}_{2} \mathrm{Cl}_{2} 1 / 1\right)$.

${ }^{1} \mathbf{H}$ NMR $\left(400 \mathrm{MHz}, \mathrm{CDCl}_{3}\right) \delta 7.25-7.17(\mathrm{~m}, 2 \mathrm{H}, \mathrm{ArH}), 6.90-6.82(\mathrm{~m}, 2 \mathrm{H}, \mathrm{ArH}), 5.09-4.66$ $\left(\mathrm{m}, 1 \mathrm{H}, \mathrm{CHCF}_{3}\right), 4.10-3.85(\mathrm{~m}, 1 \mathrm{H}, \mathrm{CHN}), 3.80(\mathrm{~s}, 3 \mathrm{H}, \mathrm{OMe}), 3.74\left(\mathrm{~s}, 2 \mathrm{H}, \mathrm{ArCH}_{2}\right), 3.30-3.18$ 
$\left(\mathrm{m}, 2 \mathrm{H}, \mathrm{CH}_{2} \mathrm{~N}\right), 2.98\left(\mathrm{~m}, 1 \mathrm{H}, \mathrm{CH}_{2} \mathrm{CC}\right), 2.26\left(\mathrm{dd}, J=16.3,10.5 \mathrm{~Hz}, 1 \mathrm{H}, \mathrm{CH}_{2} \mathrm{CC}\right), 1.47(\mathrm{~s}, 9 \mathrm{H}$, Boc), $1.06-0.98(\mathrm{~m}, 21 \mathrm{H}$, TIPS).

${ }^{13}$ C NMR (101 MHz, Chloroform- $d$ ) $\delta 159.4,154.3,130.2,129.3,124.3$ (q, $\left.J=284.2 \mathrm{~Hz}\right), 114.1$, $104.5,82.6,81.6,77.2$ (q, $J=33.3 \mathrm{~Hz}$, overlapping with chloroform signal), 59.4, 57.12, 56.0, 55.4, 28.3, 25.1, 18.5, 11.3.

IR $v_{\max } 2943$ (s), 2870 (m), 2175 (w), 1711 (s), 1374 (s), 1251 (s), 1173 (s), 1036 (m), 881 (w).

HRMS calcd for $\mathrm{C}_{29} \mathrm{H}_{45} \mathrm{~F}_{3} \mathrm{~N}_{2} \mathrm{NaO}_{3} \mathrm{Si}^{+}[\mathrm{M}+\mathrm{Na}]^{+}$577.3044; found 577.3044.

\section{Methyl 3-allyl-2-(trifluoromethyl)-5-(3-(triisopropylsilyl)prop-2-yn-1-yl)imidazolidine-1- carboxylate (11)}

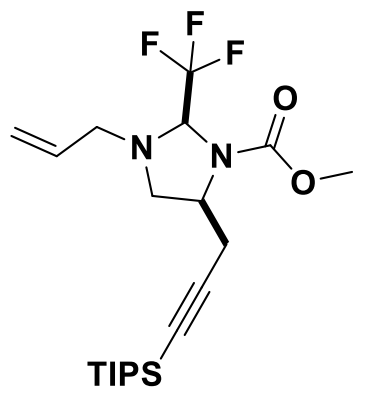

Following General Procedure A, the title compound was prepared from diallylamine $\quad(37.3 \mu \mathrm{l}, \quad 0.300 \quad \mathrm{mmol}), \quad$ 2,2,2-trifluoro-1((methoxycarbonyl)amino)ethyl acetate (2aa) $(71 \mathrm{mg}, 0.33 \mathrm{mmol}, 1.1$ equiv) and (bromoethynyl)triisopropylsilane (3) $(86.0 \mathrm{mg}, 0.330 \mathrm{mmol}$, 1.1 equiv) at $60{ }^{\circ} \mathrm{C}$. The crude oil was purified by column chromatography $\left(\mathrm{SiO}_{2}\right.$ 5:2 to 2:1 Pentane: $\left.\mathrm{CH}_{2} \mathrm{Cl}_{2}\right)$ affording the title compound 11 (124 mg, 0.287 mmol, $96 \%$ yield, $d r>20: 1$ in the crude ${ }^{19} \mathrm{~F}$ NMR) as a pale yellow oil.

Rf 0.33 (Pentane/ $\mathrm{CH}_{2} \mathrm{Cl}_{2} 5 / 2$ ).

${ }^{1} \mathbf{H}$ NMR $\left(400 \mathrm{MHz} \mathrm{CDCl}_{3}\right) \delta 5.80\left(\mathrm{ddt}, J=16.8,10.3,6.5 \mathrm{~Hz}, 1 \mathrm{H}, \mathrm{CHCH}_{2}\right), 5.24-5.20(\mathrm{~m}$, $\left.1 \mathrm{H}, \mathrm{CHCH}_{2}\right), 5.20-5.17\left(\mathrm{~m}, 1 \mathrm{H}, \mathrm{CHCH}_{2}\right), 5.02-4.78\left(\mathrm{~m}, 1 \mathrm{H}, \mathrm{CHCF}_{3}\right), 4.20-4.01(\mathrm{~m}, 1 \mathrm{H}$, $\left.\mathrm{CH}_{2} \mathrm{~N}\right), 3.75\left(\mathrm{~s}, 3 \mathrm{H}, \mathrm{CH}_{3} \mathrm{O}\right), 3.27\left(\operatorname{app~t}, J=7.5 \mathrm{~Hz}, 4 \mathrm{H}, \mathrm{CH}_{2} \mathrm{~N}\right.$ and $\left.\mathrm{CH}_{2} \mathrm{CHCH}_{2}\right), 3.08-2.91(\mathrm{~m}$, $1 \mathrm{H}, \mathrm{CH}_{2} \mathrm{CC}$ ), 2.28 (dd, $J=16.4,10.5 \mathrm{~Hz}, 1 \mathrm{H}, \mathrm{CH}_{2} \mathrm{CC}$ ), $1.09-0.95$ (m, 21H, TIPS).

${ }^{13}$ C NMR (101 MHz, Chloroform- $d$ ) $\delta 155.8,134.0,124.1(\mathrm{q}, J=284.2 \mathrm{~Hz}), 119.5,104.1,83.0$, 77.5 (m overlapping with chloroform signals), 59.1, 57.5, 56.3, 53.4, 25.1, 18.5, 11.3.

${ }^{19}$ F NMR $\left(376 \mathrm{MHz}, \mathrm{CDCl}_{3}\right) \delta-77.0$.

IR $v_{\max } 2953(\mathrm{~m}), 2864(\mathrm{w}), 2174(\mathrm{w}), 1715(\mathrm{~m}), 1448(\mathrm{~m}), 1371(\mathrm{~m}), 1177(\mathrm{~m}), 1140(\mathrm{~m}), 907$ (s).

HRMS calcd. for $\mathrm{C}_{21} \mathrm{H}_{36} \mathrm{~F}_{3} \mathrm{~N}_{2} \mathrm{O}_{2} \mathrm{Si}^{+}[\mathrm{M}+\mathrm{H}]^{+} 433.2493$; found 433.2499.

\section{Methyl 3-(furan-2-ylmethyl)-2-(trifluoromethyl)-5-(3-(triisopropylsilyl)prop-2-yn-1- yl)imidazolidine-1-carboxylate (12)}

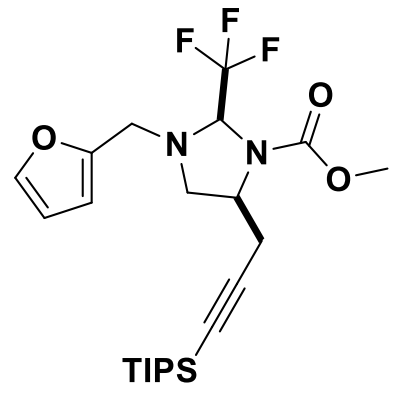

Rf 0.30 (Pentane/ $\left.\mathrm{CH}_{2} \mathrm{Cl}_{2} 2 / 1\right)$.
Following General Procedure A, the title compound was prepared from $\mathrm{N}$-(furan-2-ylmethyl)prop-2-en-1-amine (41 mg, $0.30 \mathrm{mmol}$ ), 2,2,2trifluoro-1-((methoxycarbonyl)amino)ethyl acetate (2aa) $(71 \mathrm{mg}, 0.33$ mmol, 1.1 equiv) and (bromoethynyl)triisopropylsilane (3) $(102 \mathrm{mg}$, 0.390 mmol, 1.3 equiv). The crude oil was purified by column chromatography on Biotage (SNAP cartridge KP-SIL 25 g, 92:8 to 40:60 Pentane: $\mathrm{CH}_{2} \mathrm{Cl}_{2}$ ) affording the title compound 12 (134 mg, 0.284 mmol, 92\% yield, $d r>20: 1$ in the crude ${ }^{19} \mathrm{~F} \mathrm{NMR}$ ) as a yellow oil. 
${ }^{1} \mathbf{H}$ NMR $\left(400 \mathrm{MHz}, \mathrm{CDCl}_{3}\right) \delta 7.36-7.31(\mathrm{~m}, 1 \mathrm{H}, \mathrm{Het} A r H), 6.36-6.28(\mathrm{~m}, 1 \mathrm{H}, \mathrm{HetArH}), 6.26$ - $6.20(\mathrm{~m}, 1 \mathrm{H}, \mathrm{HetArH}), 5.19$ - $4.97\left(\mathrm{~m}, 1 \mathrm{H}, \mathrm{CHCF}_{3}\right), 3.93$ - 3.79 (m, 2H, HetArCH$\left.)_{2}\right), 3.71$ (s, $\left.3 \mathrm{H}, \mathrm{CH}_{3} \mathrm{O}\right), 3.73-3.60(\mathrm{~m}, 1 \mathrm{H}, \mathrm{CHN}), 3.40\left(\mathrm{dd}, J=12.5,7.4 \mathrm{~Hz}, 1 \mathrm{H}, \mathrm{CH}_{2} \mathrm{~N}\right), 3.31(\mathrm{dd}, J=12.5$, $\left.8.7 \mathrm{~Hz}, 1 \mathrm{H}, \mathrm{CH}_{2} \mathrm{~N}\right), 3.00-2.74\left(\mathrm{~m}, 1 \mathrm{H}, \mathrm{CH}_{2} \mathrm{CC}\right), 2.21\left(\mathrm{dd}, J=16.4,10.5 \mathrm{~Hz}, 1 \mathrm{H}, \mathrm{CH}_{2} \mathrm{CC}\right), 1.15$ $-0.96(\mathrm{~m}, 21 \mathrm{H}, \mathrm{TIPS})$.

${ }^{13}$ C NMR (101 MHz, Chloroform- $d$ ) $\delta$ 155.6, 150.7, 143.1, 124.1 (q, $\left.J=283.6 \mathrm{~Hz}\right), 110.6,109.4$, $104.2,82.9,77.7$ (q, $J=34.2 \mathrm{~Hz}$, overlapping with chloroform signal), 57.7, 56.6, 53.2, 52.3, $25.2,18.8,11.3$.

${ }^{19} \mathbf{F}$ NMR $\left(376 \mathrm{MHz}, \mathrm{CDCl}_{3}\right) \delta-77.5$.

IR $v_{\max } 2955$ (s), 2869 (m), 2176 (w), 1722 (s), 1452 (m), 1367 (m), 1287 (w), 1180 (m), 1146 (m), $1022(\mathrm{w}), 883(\mathrm{w})$.

HRMS calcd for $\mathrm{C}_{23} \mathrm{H}_{36} \mathrm{~F}_{3} \mathrm{~N}_{2} \mathrm{O}_{3} \mathrm{Si}^{+}[\mathrm{M}+\mathrm{H}]^{+} 473.2442$; found 473.2447 .

Tert-butyl 3-ferrocenylmethyl-2-(trifluoromethyl)-5-(3-(triisopropylsilyl)prop-2-yn-1yl)imidazolidine-1-carboxylate (13)

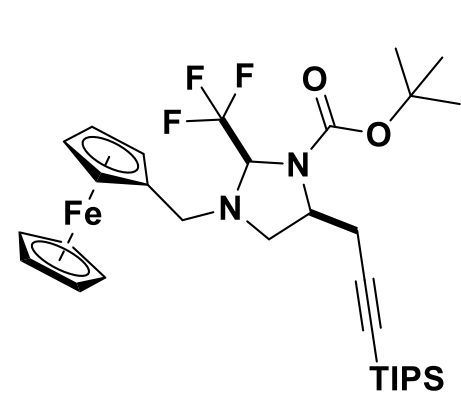

dark oil.
Following General Procedure A, the title compound was prepared from ferrocenylmethyl allylamine (54) $(76.5 \mathrm{mg}, 0.300 \mathrm{mmol}), 1$ ((tert-butoxycarbonyl)amino)-2,2,2-trifluoroethyl acetate (2a) (85 $\mathrm{mg}, 0.33 \mathrm{mmol}, 1.3$ equiv) and (bromoethynyl)triisopropylsilane (3) $(102 \mathrm{mg}, 0.390 \mathrm{mmol}, 1.3$ equiv). The crude oil ( $d r>20: 1$ by integration of the propargylic peaks in the crude ${ }^{1} \mathrm{H}$ NMR) was purified by column chromatography on Biotage (SNAP cartridge KP-SIL $25 \mathrm{~g}, 92: 8$ to 40:60 Pentane: $\mathrm{CH}_{2} \mathrm{Cl}_{2}$ ) affording the title compound 13 (168 $\mathrm{mg}, 0.266 \mathrm{mmol}, 89 \%$ yield, $d r>20: 1)$ as a

$\mathbf{R}_{\mathbf{f}} 0.20$ (Pentane/ $\left.\mathrm{CH}_{2} \mathrm{Cl}_{2} 1 / 1\right)$.

${ }^{1} \mathbf{H}$ NMR $\left(400 \mathrm{MHz}, \mathrm{CDCl}_{3}\right) \delta 4.98-4.73\left(\mathrm{~m}, 1 \mathrm{H}, \mathrm{CHCF}_{3}\right), 4.19-3.99(\mathrm{~m}, 10 \mathrm{H}, \mathrm{Ar} H$ and $\mathrm{C} H \mathrm{~N}), 3.68\left(\mathrm{~d}, J=13.9 \mathrm{~Hz}, 1 \mathrm{H}, \mathrm{ArCH}_{2}\right), 3.60\left(\mathrm{~d}, J=13.9 \mathrm{~Hz}, 1 \mathrm{H}, \mathrm{ArCH}_{2}\right), 3.31-3.11(\mathrm{~m}, 2 \mathrm{H}$, $\left.\mathrm{CH}_{2} \mathrm{~N}\right), 2.95-2.75\left(\mathrm{~m}, 1 \mathrm{H}, \mathrm{CH}_{2} \mathrm{CC}\right), 2.12\left(\mathrm{dd}, J=16.3,10.4 \mathrm{~Hz}, 1 \mathrm{H}, \mathrm{CH}_{2} \mathrm{CC}\right), 1.41(\mathrm{~s}, 9 \mathrm{H}$, Boc), $1.14-0.82(\mathrm{~m}, 21 \mathrm{H}, \mathrm{TIPS})$.

${ }^{13}$ C NMR (101 MHz, Chloroform- $d$ ) $\delta$ 153.9, $124.3 \mathrm{f}(\mathrm{q}, J=284.6 \mathrm{~Hz}), 104.6,82.4,82.0,81.3$, 77.5 (m overlapping with chloroform signal), 69.8, 69.3, 69.0, 68.8 (6C), 57.6-56.2 (3C), 28.3, $25.1,18.7,11.3$.

IR $v_{\max } 2955(\mathrm{~m}), 2869$ (m), $2176(\mathrm{w}), 1710$ (s), 1469 (w), 1373 (s), 1175 (s), 880 (w).

HRMS calcd for $\mathrm{C}_{32} \mathrm{H}_{47} \mathrm{~F}_{3} \mathrm{FeN}_{2} \mathrm{NaO}_{2} \mathrm{Si}^{+}[\mathrm{M}+\mathrm{Na}]^{+}$655.2600; found 655.2609. 


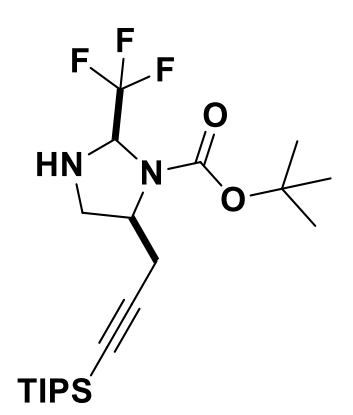

Following General Procedure A with a premixing time of $3 \mathrm{~h}$ at $35^{\circ} \mathrm{C}$, the title compound was prepared from allylamine (49) $(22.5 \mu \mathrm{l}, 0.300$ mmol), 1-((tert-butoxycarbonyl)amino)-2,2,2-trifluoroethyl acetate (2a) ( $85 \mathrm{mg}, 0.33 \mathrm{mmol}, 1.1$ equiv) and (bromoethynyl)triisopropylsilane (3) ( $86.0 \mathrm{mg}, 0.330 \mathrm{mmol}, 1.1$ equiv) at $70{ }^{\circ} \mathrm{C}$. The crude oil was purified by column chromatography $\left(\mathrm{SiO}_{2} 5: 1\right.$ to 3:1 Pentane: $\left.\mathrm{Et}_{2} \mathrm{O}\right)$ affording the title compound 14 (89.1 mg, $0.205 \mathrm{mmol}, 68 \%$ yield, $d r>20: 1$ in the crude ${ }^{1} \mathrm{H}$ NMR by integration of the propargylic signals) as a pale yellow oil.

$\mathbf{R}_{\mathbf{f}} 0.5$ (Pentane: $\mathrm{Et}_{2} \mathrm{O} 2: 1$ ).

${ }^{1} \mathbf{H}$ NMR $\left(400 \mathrm{MHz}, \mathrm{CDCl}_{3}\right) \delta 5.25-4.99\left(\mathrm{~m}, 1 \mathrm{H}, \mathrm{CHCF}_{3}\right), 4.06-3.84(\mathrm{~m}, 1 \mathrm{H}, \mathrm{NCH}), 3.61(\mathrm{dd}$, $\left.J=12.3,7.5 \mathrm{~Hz}, 1 \mathrm{H}, \mathrm{CH}_{2} \mathrm{~N}\right), 3.23-3.12\left(\mathrm{~m}, 1 \mathrm{H}, \mathrm{CH}_{2} \mathrm{~N}\right), 3.13-2.97\left(\mathrm{~m}, 1 \mathrm{H}, \mathrm{CH}_{2} \mathrm{CC}\right), 2.49-$ $2.34(\mathrm{~m}, 1 \mathrm{H}, \mathrm{NH}), 2.25$ (dd, $\left.J=16.4,10.5 \mathrm{~Hz}, 1 \mathrm{H}, \mathrm{CH}_{2} \mathrm{CC}\right), 1.47$ (s, 9H, Boc), $1.16-0.90$ (m, 21H, TIPS).

${ }^{13}$ C NMR $\left(101 \mathrm{MHz}, \mathrm{CDCl}_{3}\right) \delta 154.1,124.4(\mathrm{q}, J=283.8 \mathrm{~Hz}), 104.3,82.7,81.7,73.3(\mathrm{q}, J=$ $33.7 \mathrm{~Hz}), 58.0,52.3,28.3,25.4,18.7,11.3$.

IR $v_{\max } 3347(\mathrm{w}), 2944(\mathrm{~m}), 2866(\mathrm{w}), 2175(\mathrm{w}), 1702(\mathrm{~s}), 1464(\mathrm{w}), 1365$ (s), $1282(\mathrm{w}), 1173$ (s), $1136(\mathrm{~s}), 956(\mathrm{w}), 912(\mathrm{~m}), 878(\mathrm{~m})$.

HRMS (ESI) calcd for $\mathrm{C}_{21} \mathrm{H}_{37} \mathrm{~F}_{3} \mathrm{~N}_{2} \mathrm{NaO}_{2} \mathrm{Si}^{+}[\mathrm{M}+\mathrm{Na}]^{+}$457.2469; found 457.2458.

\section{Methyl 3-(4-methoxyphenyl)-2-(trifluoromethyl)-5-(3-(triisopropylsilyl)prop-2-yn-1- yl)imidazolidine-1-carboxylate (15)}

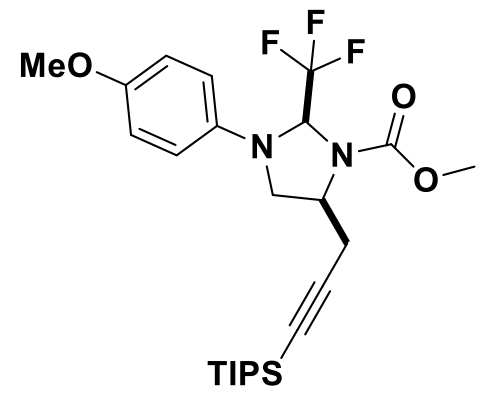

Following General Procedure A with a premixing time of $1 \mathrm{~h}$, the title compound was prepared from $\mathrm{N}$-allyl-4-methoxyaniline (49.0 $\mathrm{mg}, \quad 0.300 \quad \mathrm{mmol}), \quad 2,2,2$-trifluoro-1((methoxycarbonyl)amino)ethyl acetate (2aa) $(71 \mathrm{mg}, 0.33 \mathrm{mmol}$, 1.1 equiv) and (bromoethynyl)triisopropylsilane (3) (102 mg, $0.390 \mathrm{mmol}, 1.3$ equiv). The crude oil $\left(d r>20: 1\right.$ in the crude ${ }^{19} \mathrm{~F}$ NMR) was purified by column chromatography on Biotage (SNAP cartridge KP-SIL $25 \mathrm{~g}$, 88:12 to 5:95 Pentane: $\mathrm{CH}_{2} \mathrm{Cl}_{2}$ ) affording the title compound $\mathbf{1 5}$ (121 $\mathrm{mg}, 0.243 \mathrm{mmol}, 81 \%$ yield, $d r>20: 1$ in the ${ }^{19} \mathrm{~F} \mathrm{NMR}$ ) as a deep yellow oil.

$\mathbf{R}_{\mathbf{f}} 0.40$ (Pentane/ $\left.\mathrm{CH}_{2} \mathrm{Cl}_{2} 1 / 1\right)$.

${ }^{1} \mathbf{H}$ NMR $\left(400 \mathrm{MHz}, \mathrm{CDCl}_{3}\right) \delta 6.90-6.81(\mathrm{~m}, 2 \mathrm{H}, \mathrm{ArH}), 6.81-6.71(\mathrm{~m}, 2 \mathrm{H}, \mathrm{ArH}), 5.83-5.62$ $\left(\mathrm{m}, 1 \mathrm{H}, \mathrm{CHCF}_{3}\right), 4.38-4.20(\mathrm{~m}, 1 \mathrm{H}, \mathrm{CHN}), 3.94\left(\right.$ app t, $\left.J=9.4 \mathrm{~Hz}, 1 \mathrm{H}, \mathrm{CH}_{2} \mathrm{~N}\right), 3.80(\mathrm{~s}, 3 \mathrm{H}$, $\left.\mathrm{CH}_{3} \mathrm{O}\right), 3.77\left(\mathrm{~s}, 3 \mathrm{H}, \mathrm{CH}_{3} \mathrm{O}\right), 3.71-3.61\left(\mathrm{~m}, 1 \mathrm{H}, \mathrm{CH}_{2} \mathrm{~N}\right), 3.13-2.99\left(\mathrm{~m}, 1 \mathrm{H}, \mathrm{CH}_{2} \mathrm{CC}\right), 2.47$ (dd, $J$ $\left.=16.6,10.4 \mathrm{~Hz}, 1 \mathrm{H}, \mathrm{CH}_{2} \mathrm{CC}\right), 1.15-0.98(\mathrm{~m}, 21 \mathrm{H}, \mathrm{TIPS})$.

${ }^{13}$ C NMR (101 MHz, $\left.\mathrm{CDCl}_{3}\right) \delta 155.4,154.1,139.5,124.5(\mathrm{q}, J=288.7 \mathrm{~Hz}), 116.5,114.9,103.9$, 83.3, $74.0(\mathrm{q}, J=33.9 \mathrm{~Hz}), 56.4,55.7,54.5,53.6,25.4,18.7,11.3$.

${ }^{19} \mathbf{F}$ NMR $\left(376 \mathrm{MHz}, \mathrm{CDCl}_{3}\right) \delta-75.8$.

IR $v_{\max } 2953(\mathrm{~s}), 2869(\mathrm{~m}), 2175(\mathrm{w}), 1722(\mathrm{~s}), 1517(\mathrm{~s}), 1451$ (m), $1374(\mathrm{~m}), 1253(\mathrm{~s}), 1178(\mathrm{~s})$, $1143(\mathrm{~s}), 1038$ (m), $911(\mathrm{~s})$.

HRMS calcd for $\mathrm{C}_{25} \mathrm{H}_{38} \mathrm{~F}_{3} \mathrm{~N}_{2} \mathrm{O}_{3} \mathrm{Si}^{+}[\mathrm{M}+\mathrm{H}]^{+}$499.2598; found 499.2599. 


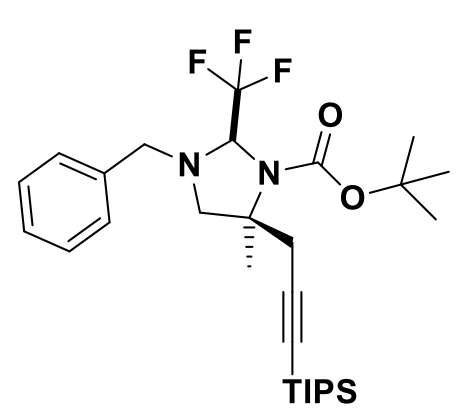

Following General Procedure $\mathbf{C}$ with a premixing time of $1 \mathrm{~h}$ and $\mathrm{Pd}_{2} \mathrm{dba}_{3}(8.2 \mathrm{mg}, 9.0 \mu \mathrm{mol}, 3 \mathrm{~mol} \%)$ and PhDavePhos $(17.1 \mathrm{mg}$, $0.0450 \mathrm{mmol}, 15 \mathrm{~mol} \%$ ), the title compound was prepared from $\mathrm{N}$ benzyl-2-methylprop-2-en-1-amine (45) (48.4 mg, $0.300 \mathrm{mmol}$ ), 1((tert-butoxycarbonyl)amino)-2,2,2-trifluoroethyl acetate (2a) (85 $\mathrm{mg}, 0.33 \mathrm{mmol}, 1.1$ equiv) and (bromoethynyl)triisopropylsilane (3) (102 mg, 0.390 mmol, 1.3 equiv). The crude oil (>20:1 dr determined by integration in the crude ${ }^{1} \mathrm{H}$ NMR) was purified by column chromatography on Biotage (SNAP cartridge KP-SIL $25 \mathrm{~g}$, 92:8 Pentane: $\mathrm{CH}_{2} \mathrm{Cl}_{2}$ to 40:60 Pentane: $\mathrm{CH}_{2} \mathrm{Cl}_{2}$ ) to afford the title compound $\mathbf{1 6}$ (137 mg, 0.254 mmol, $85 \%$ yield) as a yellow oil.

$\mathbf{R}_{\mathbf{f}} 0.30$ (Pentane/ $\mathrm{CH}_{2} \mathrm{Cl}_{2}$ 2/1).

${ }^{1} \mathbf{H}$ NMR (400 MHz, Chloroform-d) $\delta 7.43-7.21$ (m, 5H, $\mathrm{ArH}$ ), $5.14-4.98\left(\mathrm{~m}, 1 \mathrm{H}, \mathrm{CHCF}_{3}\right.$ ), $4.06\left(\mathrm{~d}, J=12.9 \mathrm{~Hz}, 1 \mathrm{H}, \mathrm{CH}_{2} \mathrm{Ph}\right), 3.99\left(\mathrm{~d}, J=13.6 \mathrm{~Hz}, 1 \mathrm{H}, \mathrm{CH}_{2} \mathrm{Ph}\right), 3.48(\mathrm{~d}, J=11.2 \mathrm{~Hz}, 1 \mathrm{H}$, $\left.\mathrm{NCH}_{2}\right), 3.26-3.02\left(\mathrm{~m}, 1 \mathrm{H}, \mathrm{CCCH}_{2}\right), 2.96\left(\mathrm{~d}, J=11.3 \mathrm{~Hz}, 1 \mathrm{H}, \mathrm{NCH}_{2}\right), 2.56(\mathrm{~d}, J=16.5 \mathrm{~Hz}, 1 \mathrm{H}$, $\left.\mathrm{CCCH}_{2}\right), 1.68$ (s, 3H, Me), 1.51 (s, 9H, Boc), $1.13-0.92$ (m, 21H, TIPS).

${ }^{13}$ C NMR (101 MHz, Chloroform- $\left.d\right) \delta 152.8,138.1,128.7,128.6,127.7,124.9(\mathrm{~d}, J=289.8 \mathrm{~Hz})$, $105.3,82.7,81.4,77.5(\mathrm{q}, J=31.9 \mathrm{~Hz}), 63.6,63.0,58.4,31.2,28.4,23.7,18.8,11.6$.

IR v $v_{\max } 3064$ (w), 2939 (w), 2862 (w), 2174 (w), 1709 (s), 1464 (w), 1363 (s), 1275 (w), 1165 (s), $1065(\mathrm{~m}), 1029(\mathrm{~m}), 883(\mathrm{~m})$.

HRMS (ESI) calcd for $\mathrm{C}_{29} \mathrm{H}_{45} \mathrm{~F}_{3} \mathrm{~N}_{2} \mathrm{NaO}_{2} \mathrm{Si}^{+}[\mathrm{M}+\mathrm{Na}]^{+}$561.3095; found 561.3099.

Stereochemistry assigned by ROESY.

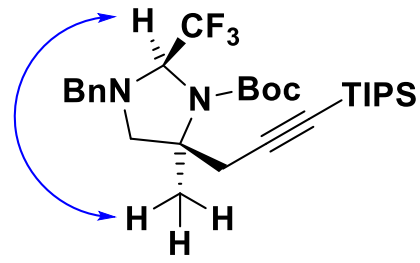

Tert-butyl 3-benzyl-5-((benzyloxy)methyl)-2-(trifluoromethyl)-5-(3-(triisopropylsilyl)prop2-yn-1-yl)imidazolidine-1-carboxylate (17)

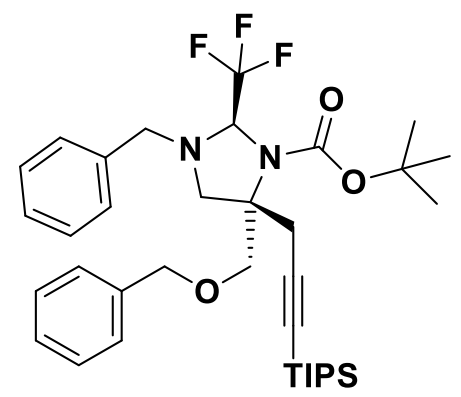

Following General Procedure $\mathbf{C}$ with a premixing time of $3 \mathrm{~h}$, the title compound was prepared from N-benzyl-2((benzyloxy)methyl)prop-2-en-1-amine (80.1 mg, $0.300 \mathrm{mmol}) \quad$ (56) (125 mg, $0.300 \mathrm{mmol}), \quad 1-(($ tert-butoxycarbonyl)amino)-2,2,2trifluoroethyl acetate (2a) (85 $\mathrm{mg}, 0.33 \mathrm{mmol}, 1.1$ equiv) and (bromoethynyl)triisopropylsilane (3) (102 mg, $0.390 \mathrm{mmol}, 1.3 \mathrm{eq}$ ). The crude oil (>20:1 dr determined by integration in the crude ${ }^{1} \mathrm{H}$ NMR) was purified by column chromatography on Biotage (SNAP cartridge KP-SIL $25 \mathrm{~g}$, 97:3 Pentane: $\mathrm{CH}_{2} \mathrm{Cl}_{2}$ to 85:15 Pentane: $\mathrm{Et}_{2} \mathrm{O}$ ) to afford the title compound $\mathbf{1 7}(135 \mathrm{mg}, 0.209 \mathrm{mmol}, 70 \%$ yield) as a yellow oil. 
$\mathbf{R}_{\mathbf{f}} 0.50$ (Pentane/Et $\left.2 \mathrm{O} 7 / 1\right)$.

${ }^{1}$ H NMR (400 MHz, Chloroform- $d$ ) $\delta 7.37$ - 7.31 (m, 4H, ArH), 7.31 - 7.19 (m, 6H, ArH), 5.06 - $4.90\left(\mathrm{~m}, 1 \mathrm{H}, \mathrm{CHCF}_{3}\right), 4.62\left(\mathrm{~d}, J=11.8 \mathrm{~Hz}, 1 \mathrm{H}, \mathrm{OCH}_{2} \mathrm{Ph}\right), 4.51\left(\mathrm{~d}, J=11.8 \mathrm{~Hz}, 1 \mathrm{H}, \mathrm{OCH} \mathrm{Ph}_{2}\right.$, $4.29-4.07\left(\mathrm{~m}, 1 \mathrm{H}, \mathrm{OCH}_{2}\right), 4.06-3.94\left(\mathrm{~m}, 2 \mathrm{H}, \mathrm{NCH}_{2} \mathrm{Ph}\right), 3.79\left(\mathrm{~d}, J=9.4 \mathrm{~Hz}, 1 \mathrm{H}, \mathrm{OCH}_{2}\right), 3.58$ $\left(\mathrm{d}, J=12.0 \mathrm{~Hz}, 1 \mathrm{H}, \mathrm{NCH}_{2}\right), 3.20\left(\mathrm{~d}, J=12.0 \mathrm{~Hz}, 1 \mathrm{H}, \mathrm{NCH}_{2}\right), 3.07$ (d, $\left.J=16.9 \mathrm{~Hz}, 1 \mathrm{H}, \mathrm{CH}_{2} \mathrm{CC}\right)$, $2.60\left(\mathrm{~d}, J=16.9 \mathrm{~Hz}, 1 \mathrm{H}, \mathrm{CH}_{2} \mathrm{CC}\right), 1.46$ (s, 9H, Boc), $1.05-0.92$ (m, 21H, TIPS).

${ }^{13}$ C NMR (101 MHz, Chloroform- $d$ ) $\delta 152.7,139.1,138.3,128.8,128.6,128.4,128.1,127.9$, $127.3,124.9(\mathrm{~d}, J=286.9 \mathrm{~Hz}), 104.1,83.4,81.3,79.2(\mathrm{q}, J=32.6 \mathrm{~Hz}), 73.9,71.2,65.9,61.7$, $59.9,28.4,28.3,18.7,11.5$.

${ }^{19}$ F NMR (376 MHz, Chloroform- $d$ ) $\delta-76.8$.

IR $v_{\max } 2945(\mathrm{~m}), 2866(\mathrm{~m}), 2173(\mathrm{w}), 1710(\mathrm{~m}), 1462$ (w), 1364 (s), 1276 (w), 1166 (s), 1132 (s), $911(\mathrm{~m})$.

HRMS (ESI) calcd or $\mathrm{C}_{36} \mathrm{H}_{52} \mathrm{~F}_{3} \mathrm{~N}_{2} \mathrm{O}_{3} \mathrm{Si}^{+}[\mathrm{M}+\mathrm{H}]^{+}$645.3694; found 645.3691.

\section{Tert-butyl 3-benzyl-4-methyl-2-(trifluoromethyl)-5-(3-(triisopropylsilyl)prop-2-yn-1- yl)imidazolidine-1-carboxylate (18)}

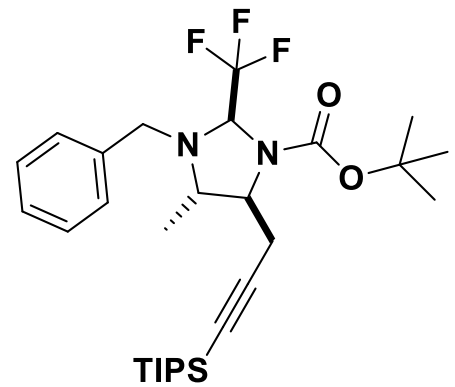

Following General Procedure B with a premixing time of $1 \mathrm{~h}$, the title compound was prepared from N-benzylbut-3-en-2-amine (46) (48.4 mg, $0.300 \mathrm{mmol}), \quad 1-(($ tert-butoxycarbonyl)amino)-2,2,2trifluoroethyl acetate (2a) (85 $\mathrm{mg}, 0.33 \mathrm{mmol}, 1.1$ equiv) and (bromoethynyl)triisopropylsilane (3) (102 mg, $0.390 \mathrm{mmol}, 1.3$ equiv). The crude oil (2.2:1 $d r$ determined by integration in the crude ${ }^{19} \mathrm{~F}$ NMR) was purified by column chromatography on Biotage (SNAP cartridge KP-SIL $25 \mathrm{~g}$, 95:5 to 60:40 Pentane: $\mathrm{CH}_{2} \mathrm{Cl}_{2}$ ) to afford the title compound 18 (132 $\mathrm{mg}, 0.245 \mathrm{mmol}, 82 \%$ yield, 2:1 $\mathrm{dr}^{25}$ determined by integration in the ${ }^{19} \mathrm{~F} \mathrm{NMR}$ ) as a yellow oil.

Rf 0.50 (Pentane/ $\mathrm{CH}_{2} \mathrm{Cl}_{2} 3 / 2$ ).

${ }^{1} \mathbf{H}$ NMR $\left(400 \mathrm{MHz}, \mathrm{CDCl}_{3}\right)$ major diastereoisomer $\delta 7.39-7.26(\mathrm{~m}, 5 \mathrm{H}, \mathrm{ArH}), 4.93-4.80(\mathrm{~m}$, $\left.1 \mathrm{H}, \mathrm{CHCF}_{3}\right), 3.99-3.86\left(\mathrm{~m}, 2 \mathrm{H}, \mathrm{PhCH}_{2}\right), 3.82-3.69(\mathrm{~m}, 1 \mathrm{H}, \mathrm{CHNBoc}), 3.56-3.46(\mathrm{~m}, 1 \mathrm{H}$, $\mathrm{C} H \mathrm{NBn}$ ), $3.00-2.87\left(\mathrm{~m}, 1 \mathrm{H}, \mathrm{CH}_{2} \mathrm{CC}\right), 2.57$ (dd, $\left.J=16.6,10.1 \mathrm{~Hz}, 1 \mathrm{H}, \mathrm{CH}_{2} \mathrm{CC}\right), 1.50$ (s, 9H, Boc), 1.30 (d, $J=6.4 \mathrm{~Hz}, 3 \mathrm{H}, \mathrm{Me}), 1.14-0.89$ (m, 21H, TIPS); minor diastereoisomer $\delta 7.39-$ $7.26(\mathrm{~m}, 5 \mathrm{H}, \mathrm{ArH}), 4.93-4.80\left(\mathrm{~m}, 1 \mathrm{H}, \mathrm{CHCF}_{3}\right), 4.29-4.20(\mathrm{~m}, 1 \mathrm{H}, \mathrm{CHNBoc}), 4.14(\mathrm{~d}, J=14.9$ $\left.\mathrm{Hz}, 1 \mathrm{H}, \mathrm{PhCH}_{2}\right), 3.93-3.87\left(\mathrm{~m}, 1 \mathrm{H}, \mathrm{PhCH}_{2}\right), 3.31-3.22(\mathrm{~m}, 1 \mathrm{H}, \mathrm{CHNBn}), 2.74-2.66(\mathrm{~m}, 1 \mathrm{H}$, $\mathrm{CH}_{2} \mathrm{CC}$ ), $2.64-2.56\left(\mathrm{~m}, 1 \mathrm{H}, \mathrm{CH}_{2} \mathrm{CC}\right), 1.48$ (s, 9H, Boc), 1.17 (d, J = 6.6 Hz, 3H, Me), $1.14-$ 0.89 (m, 21H, TIPS).

${ }^{13} \mathrm{C}$ NMR $\left(101 \mathrm{MHz}, \mathrm{CDCl}_{3}\right)$ major diastereoisomer $\delta$ 154.2, 138.2, 128.6, 128.4, 127.5, 124.9 $(\mathrm{q}, J=289.0 \mathrm{~Hz}), 104.9,83.1,81.5,74.2(\mathrm{q}, J=32.6 \mathrm{~Hz}), 63.4,60.5,50.8,28.4,24.6,18.7,16.5$, 11.5; minor diastereoisomer $\delta 153.4,137.4,128.8,128.6,127.6,124.5(\mathrm{q}, J=284.0 \mathrm{~Hz}), 106.0$, 82.5, 81.5, $75.7(\mathrm{q}, J=33.2 \mathrm{~Hz}), 61.1,60.5,56.7,28.3,21.7,18.7,15.1,11.6$.

${ }^{19} \mathbf{F}$ NMR $\left(376 \mathrm{MHz}, \mathrm{CDCl}_{3}\right) \delta-73.7,-76.7$.

IR $v_{\max } 2981$ (s), 2904 (s), 2175 (w), 1711 (s), 1460 (m), 1376 (s), 1255 (m), 1160 (s), 1065 (s), $915(\mathrm{w})$.

HRMS calcd for $\mathrm{C}_{29} \mathrm{H}_{46} \mathrm{~F}_{3} \mathrm{~N}_{2} \mathrm{O}_{2} \mathrm{Si}^{+}[\mathrm{M}+\mathrm{H}]^{+}$539.3275; found 539.3281.

${ }^{25} \mathrm{We}$ assume that the two diastereoisomers arise from different configuration at the center bound to the methyl group. 


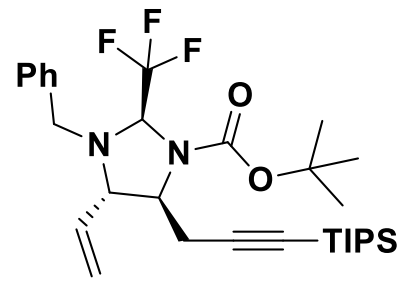

Following General Procedure $\mathbf{B}$ with a premixing time of $1 \mathrm{~h}$, the title compound was prepared from N-benzylpenta-1,4-dien-3-amine (59) (52.0 $\mathrm{mg}, \quad 0.300 \mathrm{mmol}), \quad 1$-((tert-butoxycarbonyl)amino)-2,2,2trifluoroethyl acetate (2a) (85 $\mathrm{mg}, 0.33 \mathrm{mmol}, 1.1$ equiv) and (bromoethynyl)triisopropylsilane (3) $(86 \mathrm{mg}, 0.39 \mathrm{mmol}, 1.1$ equiv). The crude oil (87:13 $d r$ determined by integration in the crude ${ }^{19} \mathrm{~F}$ NMR) was purified by column chromatography on Biotage (SNAP cartridge KP-SIL $25 \mathrm{~g}$, 90:10 to 65:35 Pentane: $\mathrm{CH}_{2} \mathrm{Cl}_{2}$ ) to afford the title compound 19 (123 $\mathrm{mg}$, $0.223 \mathrm{mmol}, 74 \%$ yield, 93:7 dr determined by integration in the ${ }^{19} \mathrm{~F} \mathrm{NMR}$ ) as a yellow oil.

$\mathbf{R}_{\mathbf{f}} 0.5$ (Pentane/Et $\left.2 \mathrm{O} 20 / 1\right)$.

${ }^{1}$ H NMR (400 MHz, Acetonitrile- $\left.d_{3}\right) \delta 7.37$ - 7.23 (m, 5H, ArH), 5.73 (ddd, $J=17.0,10.2,9.0$ $\mathrm{Hz}, 1 \mathrm{H}, \mathrm{CH}=\mathrm{C}), 5.31$ (dd, $\left.J=10.2,1.5 \mathrm{~Hz}, 1 \mathrm{H}, \mathrm{CH}_{2}=\mathrm{C}\right), 5.14\left(\mathrm{dd}, J=17.0,1.5 \mathrm{~Hz}, 1 \mathrm{H}, \mathrm{CH}_{2}=\mathrm{C}\right.$ ), $4.98\left(\mathrm{q}, J=5.3 \mathrm{~Hz}, 1 \mathrm{H}, \mathrm{CHCF}_{3}\right), 4.00\left(\mathrm{~d}, J=14.3 \mathrm{~Hz}, 1 \mathrm{H}, \mathrm{PhCH}_{2}\right), 3.94-3.84(\mathrm{~m}, 1 \mathrm{H}$, CHNBoc), 3.88 (d, $J=14.3 \mathrm{~Hz}, 1 \mathrm{H}, \mathrm{PhCH}_{2}$ ), 3.74 (dd, $\left.J=9.2,3.4 \mathrm{~Hz}, 1 \mathrm{H}, \mathrm{CHN}\right), 2.72$ (dd, $J=$ 16.9, 9.0 Hz, 1H, $\mathrm{CH}_{2} \mathrm{CC}$ ), 2.63 (dd, $J=17.0,4.7 \mathrm{~Hz}, 1 \mathrm{H}, \mathrm{CH}_{2} \mathrm{CC}$ ), 1.46 (s, 9H, Boc), $1.08-$ 0.92 (m, 21H, TIPS).

${ }^{13} \mathrm{C}$ NMR $\left(101 \mathrm{MHz}, \mathrm{CD}_{3} \mathrm{CN}\right) \delta 155.0,139.1,135.6,129.4,129.18,128.2,125.7$ (q, $J=287.1$ $\mathrm{Hz}), 121.3,105.7,83.6,82.4,74.7,67.7,63.0,51.6,28.3,24.5,19.0,12.0$.

${ }^{19}$ F NMR $\left(376 \mathrm{MHz}, \mathrm{CDCl}_{3}\right) \delta-73.8$.

IR $v_{\max } 2942(\mathrm{~m}), 2865(\mathrm{~m}), 2176(\mathrm{w}), 1716(\mathrm{~s}), 1463$ (w), 1370 (s), 1258 (w), 1161 (s), 1065 (w), $1018(\mathrm{w}), 931(\mathrm{w}), 880(\mathrm{w}), 847(\mathrm{w})$.

HRMS calcd for $\mathrm{C}_{30} \mathrm{H}_{46} \mathrm{~F}_{3} \mathrm{~N}_{2} \mathrm{O}_{2} \mathrm{Si}^{+}[\mathrm{M}+\mathrm{H}]^{+}$551.3275; found 551.3256.

Stereochemistry assigned by 1D NOESY.

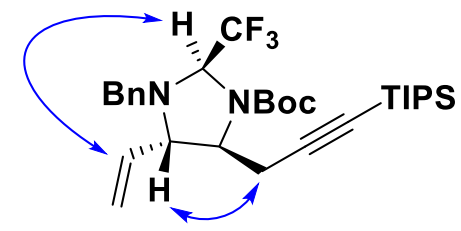

Tert-butyl 3-(trifluoromethyl)-1-(3-(triisopropylsilyl)prop-2-yn-1-yl)tetrahydro-1Hpyrrolo[1,2-c]imidazole-2(3H)-carboxylate (20)

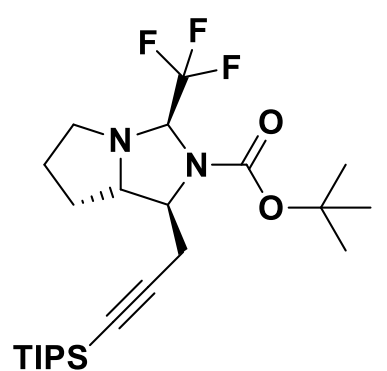

To an oven-dried $5 \mathrm{~mL}$ microwave tube under nitrogen atmosphere was added 1-((tert-butoxycarbonyl)amino)-2,2,2-trifluoroethyl acetate (2a) ( $85 \mathrm{mg}, 0.33 \mathrm{mmol}, 1.1$ equiv), cesium carbonate $(225 \mathrm{mg}, 0.690 \mathrm{mmol})$ and 2-vinylpyrrolidine hydrochloride (61) $(40.1 \mathrm{mg}, 0.300 \mathrm{mmol})$. The tube was sealed, evacuated and backfilled with nitrogen (this was repeated for a total of 3 times). Then dry toluene was added $(0.45 \mathrm{~mL})$ and the resulting mixture was stirred for $4 \mathrm{~h}$ at $50{ }^{\circ} \mathrm{C}$. Then the mixture was filtered to an oven-dried $5 \mathrm{~mL}$ microwave tube. The volatiles were removed under reduced pressure and cesium carbonate $(127 \mathrm{mg}, 0.390 \mathrm{mmol})$ was added. The tube was sealed evacuated and backfilled with nitrogen (this was repeated for a total of 3 times), then a premixed solution of $\mathrm{Pd}_{2} \mathrm{dba}_{3}(11 \mathrm{mg}, 12 \mu \mathrm{mol})$ and Tri(2-furyl)phosphine (17 mg, 0.072 $\mathrm{mmol}$ ) in toluene $(0.90 \mathrm{~mL})$ was added followed by (bromoethynyl)triisopropylsilane (3) (102 $\mathrm{mg}, 0.390 \mathrm{mmol}$ ) The resulting mixture was stirred for $20 \mathrm{~h}$ at $75^{\circ} \mathrm{C}$ in an oil bath, then cooled 
down, filtered over Celite eluting with $\mathrm{Et}_{2} \mathrm{O}$ and concentrated under reduced pressure. The crude oil (92.5:7.5 $d r$ determined by integration in the crude ${ }^{19} \mathrm{~F}$ NMR) was purified by column chromatography on Biotage (SNAP cartridge KP-SIL 25 g, 98:2 to 80:20 Pentane:Et 2 O) to afford the title compound 20 (112 mg, $0.236 \mathrm{mmol}, 79 \%$ yield, $d r>98: 2$ determined by integration in the ${ }^{19} \mathrm{~F} \mathrm{NMR}$ ) as a pale yellow oil.

$\mathbf{R}_{\mathbf{f}} 0.70$ (Pentane/Et $\left.2 \mathrm{O} 6 / 1\right)$.

${ }^{1} \mathbf{H}$ NMR $\left(400 \mathrm{MHz} \mathrm{CDCl}_{3}\right) \delta 5.10-4.77\left(\mathrm{~m}, 1 \mathrm{H}, \mathrm{CHCF}_{3}\right), 3.81-3.68(\mathrm{~m}, 1 \mathrm{H}, \mathrm{CHN}), 3.68-$ $3.44(\mathrm{~m}, 1 \mathrm{H}, \mathrm{C} H \mathrm{NBoc}), 3.32-3.21\left(\mathrm{~m}, 1 \mathrm{H}, \mathrm{CH}_{2} \mathrm{~N}\right), 3.17-2.92\left(\mathrm{~m}, 1 \mathrm{H}, \mathrm{CH}_{2} \mathrm{CC}\right), 2.63$ (app q, $J$ $\left.=8.2 \mathrm{~Hz}, 1 \mathrm{H}, \mathrm{CH}_{2} \mathrm{~N}\right), 2.29\left(\mathrm{dd}, J=13.6,7.8 \mathrm{~Hz}, 1 \mathrm{H}, \mathrm{CH}_{2} \mathrm{CC}\right), 2.25-2.17\left(\mathrm{~m}, 1 \mathrm{H}, \mathrm{NCHCH}_{2}\right)$, $1.99-1.91\left(\mathrm{~m}, 1 \mathrm{H}, \mathrm{NCHCH}_{2}\right), 1.91-1.81\left(\mathrm{~m}, 2 \mathrm{H}, \mathrm{NCH}_{2} \mathrm{CH}_{2}\right), 1.47$ (s, 9H, Boc), $1.11-0.95$ (m, 21H, TIPS).

${ }^{13}$ C NMR $\left(101 \mathrm{MHz}, \mathrm{CDCl}_{3}\right) \delta 153.9,124.0(\mathrm{q}, J=283.1 \mathrm{~Hz}), 104.0,82.9,81.6,78.7(\mathrm{q}, J=$ $33.8 \mathrm{~Hz}), 69.5,63.0,55.3,31.9,28.3,25.2,25.0,18.7,11.3$.

${ }^{19} \mathbf{F}$ NMR $\left(376 \mathrm{MHz}, \mathrm{CDCl}_{3}\right) \delta-78.4$.

IR $v_{\max } 2943(\mathrm{w}), 2867(\mathrm{w}), 2174(\mathrm{w}), 1710(\mathrm{~m}), 1464(\mathrm{w}), 1369(\mathrm{~s}), 1288(\mathrm{~m}), 1161(\mathrm{~s}), 879(\mathrm{w})$.

HRMS calcd for. $\mathrm{C}_{24} \mathrm{H}_{42} \mathrm{~F}_{3} \mathrm{~N}_{2} \mathrm{O}_{2} \mathrm{Si}^{+}[\mathrm{M}+\mathrm{H}]^{+}$475.2962; found 475.2962.

\section{Tert-butyl 3-(trifluoromethyl)-1-(3-(triisopropylsilyl)prop-2-yn-1-yl)hexahydroimidazo[1,5- a]pyridine-2(3H)-carboxylate $(21)$}

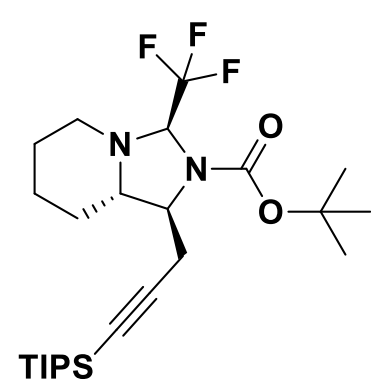

To an oven-dried $5 \mathrm{~mL}$ microwave tube under nitrogen atmosphere was added 1-((tert-butoxycarbonyl)amino)-2,2,2-trifluoroethyl acetate (2a) (85 mg, $0.33 \mathrm{mmol}, 1.1$ equiv), cesium carbonate $(225 \mathrm{mg}, 0.690 \mathrm{mmol})$ and 2-vinylpiperidine 2,2,2-trifluoroacetate $(63)(67.6 \mathrm{mg}, 0.300 \mathrm{mmol})$. The tube was sealed, evacuated and backfilled with nitrogen (this was repeated for a total of 3 times). Then dry toluene was added $(0.45 \mathrm{~mL})$ and the resulting mixture was stirred for $4 \mathrm{~h}$ at $50{ }^{\circ} \mathrm{C}$. Then the mixture was filtered to an oven-dried $5 \mathrm{~mL}$ microwave tube. The volatiles were removed under reduced pressure and cesium carbonate $(127 \mathrm{mg}, 0.390$ mmol) was added. The tube was sealed, evacuated and backfilled with nitrogen (this was repeated for a total of 3 times), then a premixed solution of $\mathrm{Pd}_{2} \mathrm{dba}_{3}(11 \mathrm{mg}, 12 \mu \mathrm{mol})$ and Tri(2furyl)phosphine (17 mg, $0.072 \mathrm{mmol})$ in toluene $(0.90 \mathrm{~mL})$ was added followed by (bromoethynyl)triisopropylsilane $(3)(102 \mathrm{mg}, 0.390 \mathrm{mmol})$ The resulting mixture was stirred for $20 \mathrm{~h}$ at $75{ }^{\circ} \mathrm{C}$ in an oil bath, then cooled down, filtered over Celite eluting with $\mathrm{Et}_{2} \mathrm{O}$ and concentrated under reduced pressure. The crude oil (90:10 $d r$ determined by integration in the crude ${ }^{1} \mathrm{H}$ NMR) was purified by column chromatography on Biotage (SNAP cartridge KP-SIL 25 g, 95:5 to 80:20 Pentane:Et ${ }_{2} \mathrm{O}$ ) to afford the title compound 21 (113 mg, 0.231 mmol, $77 \%$ yield, $d r>98: 2$ determined by integration in the ${ }^{1} \mathrm{H}$ NMR) as a yellow oil.

$\mathbf{R}_{\mathbf{f}} 0.75$ (Pentane/Et $\left.{ }_{2} \mathrm{O} 6 / 1\right)$.

${ }^{1} \mathbf{H}$ NMR $\left(400 \mathrm{MHz}, \mathrm{CDCl}_{3}\right) \delta 4.46-4.26\left(\mathrm{~m}, 1 \mathrm{H}, \mathrm{CHCF}_{3}\right), 4.26-4.04(\mathrm{~m}, 1 \mathrm{H}, \mathrm{CHNBoc}), 3.34$ - $3.20\left(\mathrm{~m}, 1 \mathrm{H}, \mathrm{NCH}_{2}\right.$ ), $2.64\left(\mathrm{dd}, J=17.0,10.1 \mathrm{~Hz}, 1 \mathrm{H}, \mathrm{CH}_{2} \mathrm{CC}\right.$ ), $2.56-2.43$ (overlapping m, $2 \mathrm{H}$, $\mathrm{CH}_{2} \mathrm{CC}$ and $\left.\mathrm{CHN}\right), 2.32\left(\mathrm{td}, J=11.0,3.5 \mathrm{~Hz}, 1 \mathrm{H}, \mathrm{NCH}_{2}\right), 1.85$ (app t, $\left.J=16.3 \mathrm{~Hz}, 2 \mathrm{H}\right), 1.66-$ 1.45 (m, 3H), 1.47 (s, 9H, Boc), $1.34-1.14$ (m, 1H), $1.11-0.96$ (m, 21H, TIPS)

${ }^{13}$ C NMR $\left(101 \mathrm{MHz}, \mathrm{CDCl}_{3}\right) \delta 153.6,124.3(\mathrm{q}, J=283.9 \mathrm{~Hz}), 105.6,82.0,81.5,76.5-74.8(\mathrm{~m})$, $65.2,61.1-58.8(\mathrm{~m}), 51.8,28.3,26.8,25.3,23.8,21.7,18.7,11.4$.

IR $v_{\max } 2953$ (s), 2865 (s), $2177(\mathrm{w}), 1716(\mathrm{~s}), 1464(\mathrm{w}), 1371$ (s), $1277(\mathrm{w}), 1166$ (s), $1041(\mathrm{w})$, $1003(\mathrm{w}), 932(\mathrm{w}), 881(\mathrm{~m}), 861(\mathrm{~m})$. 
HRMS calcd for $\mathrm{C}_{25} \mathrm{H}_{44} \mathrm{~F}_{3} \mathrm{~N}_{2} \mathrm{O}_{2} \mathrm{Si}^{+}[\mathrm{M}+\mathrm{H}]^{+} 489.3119$; found 489.3125.

\section{Tert-butyl 3-(trifluoromethyl)-1-(3-(triisopropylsilyl)prop-2-yn-1-yl)tetrahydro-1H- pyrrolo[1,2-c]imidazole-2(3H)-carboxylate (22)}

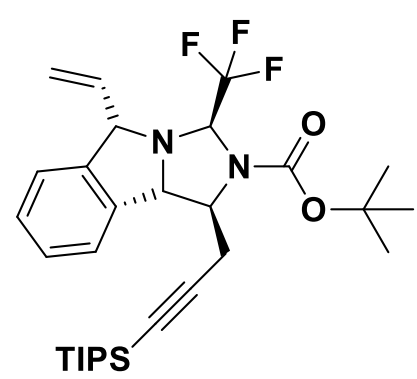

Following General Procedure B with a premixing time of $4 \mathrm{~h}$ at $70{ }^{\circ} \mathrm{C}$, the title compound was prepared from $c$ is-1,3-divinylisoindoline (65) (51.4 $\mathrm{mg}, \quad 0.300 \mathrm{mmol}), \quad 1-(($ tert-butoxycarbonyl)amino)-2,2,2trifluoroethyl acetate (2a) (85 $\mathrm{mg}, 0.33 \mathrm{mmol}, 1.1$ equiv) and (bromoethynyl)triisopropylsilane (3) (102 mg, $0.390 \mathrm{mmol}, 1.3$ equiv). The crude oil $\left(d r>98: 2\right.$ determined by integration in the crude ${ }^{19} \mathrm{~F}$ NMR) was purified by column chromatography on Biotage (SNAP cartridge KP-SIL $25 \mathrm{~g}$, 90:10 to 40:60 Pentane: $\mathrm{CH}_{2} \mathrm{Cl}_{2}$ ) to afford the title compound 22 (92 mg, $0.168 \mathrm{mmol}, 56 \%$ yield, $d r>98: 2$ determined by integration in the ${ }^{19} \mathrm{~F} \mathrm{NMR}$ ) as a yellow oil.

$\mathbf{R}_{\mathbf{f}} 0.40$ (Pentane/ $\mathrm{CH}_{2} \mathrm{Cl}_{2} 3 / 2$ ).

${ }^{1}$ H NMR $\left(400 \mathrm{MHz}\right.$, Benzene- $\left.d_{6}\right) \delta 7.88(\operatorname{app} \mathrm{d}, J=7.5 \mathrm{~Hz}, 1 \mathrm{H}, \operatorname{Ar} H), 7.23-7.13(\mathrm{~m}$ overlapping with benzene- $d_{6}$ signal, $\left.1 \mathrm{H}, \mathrm{ArH}\right), 7.08$ (app t, $\left.J=7.6 \mathrm{~Hz}, 1 \mathrm{H}, \mathrm{ArH}\right), 6.87(\mathrm{~d}, J=7.6$ $\mathrm{Hz}, 1 \mathrm{H}, \mathrm{Ar} H), 5.65-5.32\left(\mathrm{~m}, 1 \mathrm{H}, \mathrm{CHCF}_{3}\right), 5.31-5.14\left(\mathrm{~m}, 1 \mathrm{H}, \mathrm{CHCH}_{2}\right), 5.10(\mathrm{~d}, J=7.2 \mathrm{~Hz}$, $1 \mathrm{H}, \mathrm{CHN}), 4.98\left(\operatorname{app~d}, J=16.9 \mathrm{~Hz}, 1 \mathrm{H}, \mathrm{CHCH}_{2}\right), 4.91\left(\operatorname{app~d}, J=9.8 \mathrm{~Hz}, 1 \mathrm{H}, \mathrm{CHCH}_{2}\right), 4.79(\mathrm{~d}$, $J=9.8 \mathrm{~Hz}, 1 \mathrm{H}, \mathrm{CHAr}), 3.88-3.75(\mathrm{~m}, 1 \mathrm{H}, \mathrm{CHNBoc}), 3.27\left(\right.$ app d, $\left.J=16.8 \mathrm{~Hz}, 1 \mathrm{H}, \mathrm{CCCH}_{2}\right)$, 2.69 (dd, $J=16.8,9.9 \mathrm{~Hz}, 1 \mathrm{H}, \mathrm{CCCH}_{2}$ ), 1.30 (s, 9H, Boc), $1.24-1.09$ (m, 21H, TIPS).

${ }^{13}$ C NMR (101 MHz, $\left.\mathrm{C}_{6} \mathrm{D}_{6}\right) \delta 153.2,141.2,139.9,137.7,128.5,127.9,125.4(\mathrm{q}, J=282.9 \mathrm{~Hz})$, 124.8, 123.9, 119.9, 105.9, 84.1, 81.1, 75.7, 74.4 (q, $J=34.6 \mathrm{~Hz}), 72.5,64.0,28.2,25.9$, 19.0, 11.9 .

${ }^{19} \mathbf{F}$ NMR $\left(376 \mathrm{MHz}, \mathrm{CDCl}_{3}\right) \delta-77.7$.

IR $v_{\max } 2944(\mathrm{~m}), 2868(\mathrm{w}), 2172(\mathrm{w}), 1711(\mathrm{~m}), 1468$ (w), 1363 (s), $1286(\mathrm{~m}), 1153$ (s), 1004 (w), $932(\mathrm{w}), 877(\mathrm{w})$.

HRMS calcd for $\mathrm{C}_{30} \mathrm{H}_{44} \mathrm{~F}_{3} \mathrm{~N}_{2} \mathrm{O}_{2} \mathrm{Si}^{+}[\mathrm{M}+\mathrm{H}]^{+}$549.3119; found 549.3130.

Stereochemistry assigned by 1D NOESY.

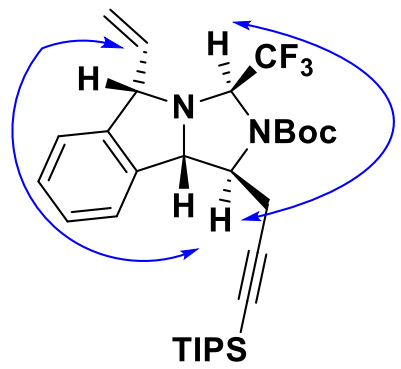




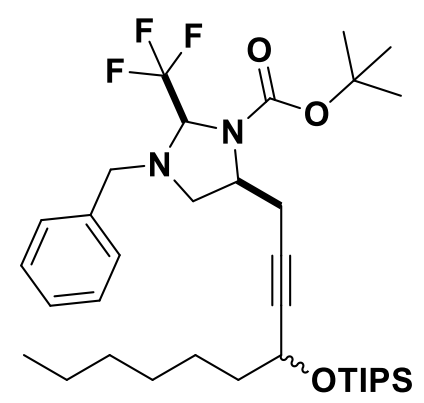

Following General Procedure A, using $\mathrm{Pd}_{2} \mathrm{dba}_{3}(11.0 \mathrm{mg}, 12.0 \mu \mathrm{mol})$ and DPEPhos (19.4 $\mathrm{mg}, 0.036 \mathrm{mmol})$, the title compound was prepared from N-benzylprop-2-en-1-amine (1) (44.2 mg, $0.300 \mathrm{mmol})$, 1-((tert-butoxycarbonyl)amino)-2,2,2-trifluoroethyl acetate (2a) (85 $\mathrm{mg}, \quad 0.33$ mmol, 1.1 equiv) and ((1-bromonon-1-yn-3yl)oxy)triisopropylsilane (78) (0.146 g, $0.390 \mathrm{mmol}, 1.3 \mathrm{equiv})$. The crude oil (1:1 dr at the propargylic center determined by integration in the crude ${ }^{1} \mathrm{H}$ NMR) was purified by column chromatography on Biotage (SNAP cartridge KP-SIL $25 \mathrm{~g}$, 85:15 to 40:60 Pentane: $\left.\mathrm{CH}_{2} \mathrm{Cl}_{2}\right)$ to afford the title compound $23(0.170 \mathrm{~g}, 0.266 \mathrm{mmol}, 89 \%$ yield $)$ as a yellow oil.

$\mathbf{R}_{\mathbf{f}} 0.28$ (Pentane: $\mathrm{CH}_{2} \mathrm{Cl}_{2} 2: 1$ ).

${ }^{1} \mathbf{H}$ NMR (400 MHz, $\left.\mathrm{CDCl}_{3}\right) \delta 7.37-7.27(\mathrm{~m}, 5 \mathrm{H}, \mathrm{ArH}), 5.00-4.73\left(\mathrm{~m}, 1 \mathrm{H}, \mathrm{CHCF}_{3}\right), 4.37(\mathrm{td}$, $J=6.4,1.7 \mathrm{~Hz}, 1 \mathrm{H}, \mathrm{CHOTIPS}), 4.09-3.88(\mathrm{~m}, 1 \mathrm{H}, \mathrm{CHN}), 3.88-3.76\left(\mathrm{~m}, 2 \mathrm{H}, \mathrm{CH}_{2} \mathrm{Ph}\right), 3.26-$ $3.13\left(\mathrm{~m}, 2 \mathrm{H}, \mathrm{CH}_{2} \mathrm{~N}\right), 3.04-2.78\left(\mathrm{~m}, 1 \mathrm{H}, \mathrm{CH}_{2} \mathrm{CC}\right), 2.25$ (app ddt, $J=16.3,10.6,1.7 \mathrm{~Hz}, 1 \mathrm{H}$, $\left.\mathrm{CH}_{2} \mathrm{CC}\right), 1.64-1.57(\mathrm{~m}, 2 \mathrm{H}), 1.52-1.44\left(\mathrm{~m}, 10 \mathrm{H}, \mathrm{Boc}\right.$ and $\left.\mathrm{CH}_{2}\right), 1.44-1.33\left(\mathrm{~m}, 1 \mathrm{H}, \mathrm{CH}_{2}\right)$, $1.32-1.22\left(\mathrm{~m}, 6 \mathrm{H}, \mathrm{CH}_{2} \mathrm{CH}_{2} \mathrm{CH}_{2}\right), 1.12-0.97(\mathrm{~m}, 21 \mathrm{H}, \mathrm{TIPS}), 0.88\left(\mathrm{t}, J=6.8 \mathrm{~Hz}, 3 \mathrm{H}, \mathrm{CH}_{3}\right)$.

${ }^{13}$ C NMR $\left(101 \mathrm{MHz}, \mathrm{CDCl}_{3}\right) \delta 154.2,137.4,128.8,128.7,128.0,124.3$ (q, $\left.J=284.7 \mathrm{~Hz}\right), 84.1$, 81.6, 80.0, 77.3 (m overlapping with chloroform signal), 63.3, 60.0, 57.1, 55.9, 39.2, 31.9, 29.2, 28.3, 25.1, 24.0, 22.7, 18.2, 18.1 (diastereoisomer), 14.2, 12.4.

IR $v_{\max } 2938$ (w), 2853 (w), 1714 (s), 1465 (w), 1364 (s), 1287 (w), 1172 (s), 882 (w).

HRMS (ESI) calcd for $\mathrm{C}_{35} \mathrm{H}_{57} \mathrm{~F}_{3} \mathrm{~N}_{2} \mathrm{NaO}_{3} \mathrm{Si}^{+}[\mathrm{M}+\mathrm{Na}]^{+}$661.3983; found 661.3980.

Tert-butyl

3-benzyl-5-(4-methyl-4-((triisopropylsilyl)oxy)pent-2-yn-1-yl)-2(trifluoromethyl)imidazolidine-1-carboxylate (24)

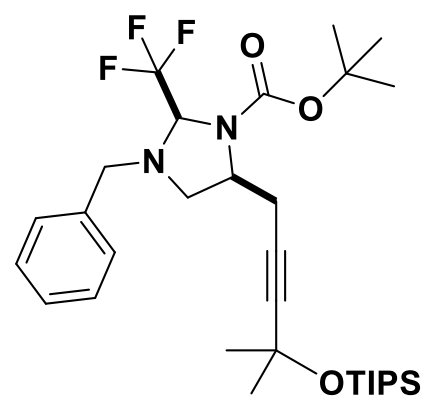

Following General Procedure A, using $\mathrm{Pd}_{2} \mathrm{dba}_{3}(11.0 \mathrm{mg}, 12.0 \mu \mathrm{mol})$ and DPEPhos (19.4 $\mathrm{mg}, 0.036 \mathrm{mmol})$, the title compound was prepared from N-benzylprop-2-en-1-amine (1) (44.2 mg, 0.300 mmol), 1-((tert-butoxycarbonyl)amino)-2,2,2-trifluoroethyl acetate (2a) (85 mg, $0.33 \mathrm{mmol}, 1.1$ equiv) and ((4-bromo-2-methylbut-3yn-2-yl)oxy)triisopropylsilane (73) (125 mg, $0.390 \mathrm{mmol}, 1.3 \mathrm{equiv})$. The crude oil (>20:1 dr determined by integration in the crude ${ }^{1} \mathrm{H}$ NMR) was purified by column chromatography on Biotage (SNAP cartridge KP-SIL $25 \mathrm{~g}$, 90:10 to $60: 40$ Pentane: $\mathrm{CH}_{2} \mathrm{Cl}_{2}$ ) to give the title compound 24 (133 mg, $0.228 \mathrm{mmol}, 76 \%$ yield) as a yellow oil.

Rf 0.50 (Pentane/ $\left.\mathrm{CH}_{2} \mathrm{Cl}_{2} 1 / 1\right)$.

${ }^{1} \mathbf{H}$ NMR $\left(400 \mathrm{MHz}, \mathrm{CDCl}_{3}\right) \delta 7.38-7.27(\mathrm{~m}, 5 \mathrm{H}, \mathrm{ArH}), 5.05-4.71\left(\mathrm{~m}, 1 \mathrm{H}, \mathrm{CHCF}_{3}\right), 3.98(\mathrm{~s}$, $1 \mathrm{H}, \mathrm{CHN}), 3.87-3.76\left(\mathrm{~m}, 2 \mathrm{H}, \mathrm{CH}_{2} \mathrm{Ph}\right), 3.23-3.12\left(\mathrm{~m}, 2 \mathrm{H}, \mathrm{CH}_{2} \mathrm{~N}\right), 2.97-2.77(\mathrm{~m}, 1 \mathrm{H}$, $\mathrm{CH}_{2} \mathrm{CC}$ ), 2.24 (dd, $J=16.2,10.3 \mathrm{~Hz}, 1 \mathrm{H}, \mathrm{CH}_{2} \mathrm{CC}$ ), 1.47 (s, 9H, Boc), 1.43 (s, 3H, Me), 1.43 (s, $3 \mathrm{H}, \mathrm{Me}), 1.13-0.98$ (m, 21H, TIPS). 
${ }^{13} \mathrm{C}$ NMR $\left(101 \mathrm{MHz}, \mathrm{CDCl}_{3}\right) \delta 154.2,137.4,128.9,128.8,128.0,124.28(\mathrm{q}, J=283.9 \mathrm{~Hz}), 87.7$, 81.6, 78.1, 77.2 (m overlapping with chloroform signal), 66.3, 60.0, 57.1, 55.7, 33.5, 28.4, 24.0, $18.4,13.1$.

IR $v_{\max } 2940(\mathrm{~m}), 2866(\mathrm{w}), 2239$ (w), 1715 (s), 1464 (w), 1366 (s), $1246(\mathrm{~m}), 1165$ (s), 1062 (w), $881(\mathrm{w})$.

HRMS calcd for for $\mathrm{C}_{35} \mathrm{H}_{57} \mathrm{~F}_{3} \mathrm{~N}_{2} \mathrm{NaO}_{3} \mathrm{Si}^{+}[\mathrm{M}+\mathrm{Na}]^{+}$661.3983; found 661.3980.

\section{Tert-butyl 3-benzyl-5-(4-(benzyloxy)-4-methylpent-2-yn-1-yl)-2-} (trifluoromethyl)imidazolidine-1-carboxylate (25)

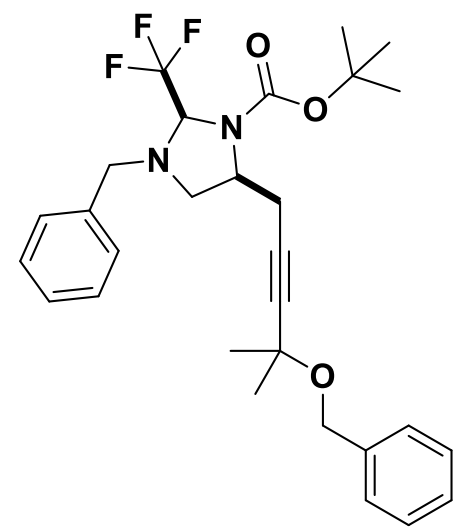

Following General Procedure A, using $\mathrm{Pd}_{2} \mathrm{dba}_{3}(11.0 \mathrm{mg}, 12.0$ $\mu \mathrm{mol})$ and DPEPhos (19.4 $\mathrm{mg}, 0.036 \mathrm{mmol})$, the title compound was prepared from N-benzylprop-2-en-1-amine (1) (44.2 $\mathrm{mg}, 0.300$ mmol), 1-((tert-butoxycarbonyl)amino)-2,2,2-trifluoroethyl acetate (2a) $(85 \mathrm{mg}, 0.33 \mathrm{mmol}, 1.1$ equiv) and ((1-bromonon-1-yn-3yl)oxy)triisopropylsilane (75) (0.146 g, $0.390 \mathrm{mmol}, 1.3$ equiv). The crude oil was purified by column chromatography on Biotage (SNAP cartridge KP-SIL $25 \mathrm{~g}, 80: 20$ to $0: 10$ Pentane: $\mathrm{CH}_{2} \mathrm{Cl}_{2}$ ) to afford the title compound $(95.4 \mathrm{mg}, 0.184 \mathrm{mmol}, 62 \%$ yield) as a yellow oil.

$\mathbf{R}_{\mathbf{f}} 0.30$ (Pentane: $\mathrm{Et}_{2} \mathrm{O} 4: 1$ ).

${ }^{1} \mathbf{H}$ NMR $\left(400 \mathrm{MHz}, \mathrm{CDCl}_{3}\right) \delta 7.36-7.28(\mathrm{~m}, 9 \mathrm{H}, \mathrm{ArH}), 7.28-7.24(\mathrm{~m}, 1 \mathrm{H}, \mathrm{ArH}), 4.96-4.70$ $\left(\mathrm{m}, 1 \mathrm{H}, \mathrm{CHCF}_{3}\right), 4.54\left(\mathrm{~s}, 2 \mathrm{H}, \mathrm{CH}_{2} \mathrm{O}\right), 4.13-3.88(\mathrm{~m}, 1 \mathrm{H}, \mathrm{CHN}), 3.84-3.74(\mathrm{~m}, 2 \mathrm{H}, \mathrm{NCH} 2 \mathrm{Ph})$, $3.27-3.11\left(\mathrm{~m}, 2 \mathrm{H}, \mathrm{CH}_{2} \mathrm{~N}\right), 2.98-2.81\left(\mathrm{~m}, 1 \mathrm{H}, \mathrm{CH}_{2} \mathrm{CC}\right), 2.34(\mathrm{dd}, J=16.3,10.0 \mathrm{~Hz}, 1 \mathrm{H}$, $\mathrm{CH}_{2} \mathrm{CC}$ ), 1.47 (app s, $15 \mathrm{H}, \mathrm{CH}_{3}$ and Boc).

${ }^{13}$ C NMR (101 MHz, $\left.\mathrm{CDCl}_{3}\right) \delta 154.2,139.3,137.3,128.8,128.7,128.4,128.0,127.7,127.4$, $124.2(\mathrm{q}, J=284.5 \mathrm{~Hz}), 84.4,81.7,80.4,77.2$ (m overlapping with chloroform signal), 70.8, $66.5,59.9,56.9,55.8,29.2,28.3,23.7$.

IR $v_{\max } 2986(\mathrm{~s}), 2906(\mathrm{~m}), 2177(\mathrm{w}), 1706(\mathrm{w}), 1385$ (m), 1246 (w), 1061 (s), $906(\mathrm{w})$.

HRMS (ESI) calcd for $\mathrm{C}_{29} \mathrm{H}_{36} \mathrm{~F}_{3} \mathrm{~N}_{2} \mathrm{O}_{3}{ }^{+}[\mathrm{M}+\mathrm{H}]^{+}$517.2673; found 517.2675.

\section{Methyl 3-benzyl-5-(4-((tert-butyldimethylsilyl)oxy)-5,5,5-trifluoro-4-phenylpent-2-yn-1-yl)-} 2-(trifluoromethyl)imidazolidine-1-carboxylate (26)

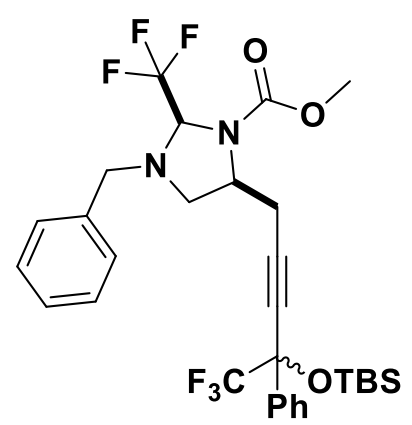

mmol, $96 \%$ yield) as a yellow oil.

Following General Procedure A, using $\mathrm{Pd}_{2} \mathrm{dba}_{3}(11.0 \mathrm{mg}, 12.0 \mu \mathrm{mol})$ and DPEPhos (19.4 mg, $0.036 \mathrm{mmol})$, the title compound was prepared from N-benzylprop-2-en-1-amine (1) (44.2 mg, $0.300 \mathrm{mmol}$ ), 2,2,2trifluoro-1-((methoxycarbonyl)amino)ethyl acetate (2a) $(71 \mathrm{mg}, 0.33$ mmol, 1.1 equiv) and ((4-bromo-1,1,1-trifluoro-2-phenylbut-3-yn-2yl)oxy)(tert-butyl)dimethylsilane (81) (153 mg, $0.390 \mathrm{mmol}, 1.3$ equiv). The crude oil (1:1 dr at the propargylic center, determined by integration in the crude ${ }^{1} \mathrm{H}$ NMR) was purified by column chromatography on Biotage (SNAP cartridge KP-SIL 25 g, 97:3 to 85:15 Pentane:Et $\left.{ }_{2} \mathrm{O}\right)$ to afford the title compound 26 (0.177 g, 0.288 Rf 0.25 (Pentane: $\mathrm{Et}_{2} \mathrm{O} 8: 1$ ). 
${ }^{1} \mathbf{H}$ NMR $\left(400 \mathrm{MHz}, \mathrm{CDCl}_{3}\right) \delta 7.71-7.62(\mathrm{~m}, 2 \mathrm{H}, \mathrm{ArH}), 7.41-7.27(\mathrm{~m}, 8 \mathrm{H}, \mathrm{ArH}), 5.10-4.86$ $\left(\mathrm{m}, 1 \mathrm{H}, \mathrm{CHCF}_{3}\right), 4.24-4.04(\mathrm{~m}, 1 \mathrm{H}, \mathrm{CHN}), 3.98-3.86\left(\mathrm{~m}, 1 \mathrm{H}, \mathrm{CH}_{2} \mathrm{Ph}\right), 3.81(\mathrm{~d}, J=13.1 \mathrm{~Hz}$, $1 \mathrm{H}, \mathrm{CH}_{2} \mathrm{Ph}$ ), 3.77 (s, $3 \mathrm{H}$, OMe for the first diastereoisomer), 3.75 (s, 3H, OMe for the second diastereoisomer) $3.33-3.18\left(\mathrm{~m}, 2 \mathrm{H}, \mathrm{CH}_{2} \mathrm{~N}\right), 3.18-2.98\left(\mathrm{~m}, 1 \mathrm{H}, \mathrm{CH}_{2} \mathrm{CC}\right), 2.42(\mathrm{dd}, J=16.5$, $\left.10.1 \mathrm{~Hz}, 1 \mathrm{H}, \mathrm{CH}_{2} \mathrm{CC}\right), 0.96(\mathrm{~s}, 9 \mathrm{H}, t-\mathrm{Bu}), 0.20(\operatorname{app~d}, J=3.5 \mathrm{~Hz}, 3 \mathrm{H}, \mathrm{Me}),-0.03$ (app d, $J=2.2$ $\mathrm{Hz}, 3 \mathrm{H}, \mathrm{Me})$.

${ }^{13}$ C NMR $\left(101 \mathrm{MHz}, \mathrm{CDCl}_{3}\right) \delta 155.6,137.5,136.9,129.2,128.9,128.8,128.1,128.0,127.5$, 124.1 (q, $J=284.5 \mathrm{~Hz}$ ), 123.4 (q, $J=286.3 \mathrm{~Hz}$ ), 86.2, 78.7 (first diastereoisomer), 78.7 (second diastereoisomer), 77.3 (m overlapping with chloroform signal), $74.4(\mathrm{q}, J=32.4 \mathrm{~Hz}), 59.9,57.1$, $55.7,53.5,25.8,24.0,18.5,-3.2,-3.3$.

IR $v_{\max } 2956(\mathrm{w}), 2854(\mathrm{w}), 2248(\mathrm{w}), 1720(\mathrm{~m}), 1447(\mathrm{~m}), 1360(\mathrm{w}), 1264(\mathrm{w}), 1172(\mathrm{~s}), 1146$ (m), $1099(\mathrm{~m}), 915(\mathrm{w}), 864(\mathrm{~m})$.

HRMS calcd for $\mathrm{C}_{30} \mathrm{H}_{37} \mathrm{~F}_{6} \mathrm{~N}_{2} \mathrm{O}_{3} \mathrm{Si}^{+}[\mathrm{M}+\mathrm{H}]^{+}$615.2472; found 615.2494.

\section{Tert-butyl 3-benzyl-5-(2-fluorobenzyl)-2-(trifluoromethyl)imidazolidine-1-carboxylate (27)}

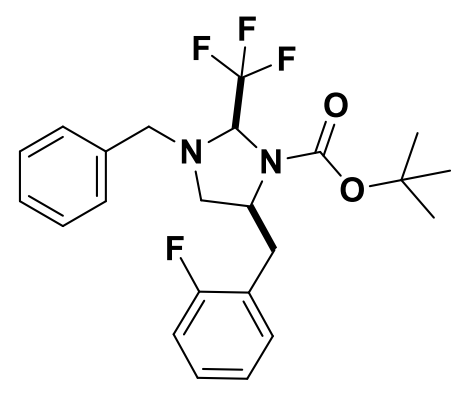

Following General Procedure D, the title compound was prepared from N-benzylprop-2-en-1-amine (1) (44.2 mg, $0.300 \mathrm{mmol}), 1$ ((tert-butoxycarbonyl)amino)-2,2,2-trifluoroethyl acetate (2a) (85 $\mathrm{mg}, 0.33 \mathrm{mmol}, 1.1$ equiv) and 1-bromo-2-fluorobenzene (47) (79 $\mathrm{mg}, 0.45 \mathrm{mmol}, 1.5$ equiv) at $70{ }^{\circ} \mathrm{C}$. The crude oil $(d r>20: 1$ determined by integration in the ${ }^{1} \mathrm{H}$ NMR of the crude) was purified by column chromatography on Biotage (SNAP cartridge KP-SIL 25 g, 85:15 to 40:60 Pentane: $\mathrm{CH}_{2} \mathrm{Cl}_{2}$ ) to afford the title compound 27 (108 mg, $0.246 \mathrm{mmol}, 82 \%$ yield) as a yellow oil.

Rf 0.40 (Pentane: $\mathrm{CH}_{2} \mathrm{Cl}_{2} 5: 7$ ).

${ }^{1} \mathbf{H}$ NMR $\left(400 \mathrm{MHz}, \mathrm{CDCl}_{3}\right) \delta 7.37-7.26(\mathrm{~m}, 5 \mathrm{H}, \mathrm{ArH}), 7.23-7.14(\mathrm{~m}, 2 \mathrm{H}, \mathrm{ArH}), 7.08-6.97$ $(\mathrm{m}, 2 \mathrm{H}, \mathrm{ArH}), 5.08-4.79\left(\mathrm{~m}, 1 \mathrm{H}, \mathrm{CHCF}_{3}\right), 4.32-4.17(\mathrm{~m}, 1 \mathrm{H}, \mathrm{CHN}), 3.88(\mathrm{~d}, J=13.4 \mathrm{~Hz}, 1 \mathrm{H}$ $\left.\mathrm{PhCH}_{2}\right), 3.74\left(\mathrm{~d}, J=13.2 \mathrm{~Hz}, 1 \mathrm{H}, \mathrm{PhCH}_{2}\right), 3.40-3.26(\mathrm{~m}, 1 \mathrm{H}, \mathrm{NCH}), 3.13(\mathrm{dd}, J=11.6,6.9$ $\left.\mathrm{Hz}, 1 \mathrm{H}, \mathrm{ArCH}_{2}\right), 2.88\left(\mathrm{dd}, J=11.6,7.4 \mathrm{~Hz}, 1 \mathrm{H}, \mathrm{ArCH}_{2}\right), 2.84-2.71\left(\mathrm{~m}, 1 \mathrm{H}, \mathrm{NCH}_{2}\right), 1.48$ (s, 9H, Boc).

${ }^{13} \mathrm{C}$ NMR $\left(101 \mathrm{MHz}, \mathrm{CDCl}_{3}\right) \delta 161.4(\mathrm{~d}, J=245.4 \mathrm{~Hz}), 154.6,137.6,131.8(\mathrm{~d}, J=4.9 \mathrm{~Hz})$, $128.7,128.6,128.4$ (d, $J=8.0 \mathrm{~Hz}), 127.8,125.0(\mathrm{~d}, J=16.2 \mathrm{~Hz}), 124.41(\mathrm{q}, J=284.4 \mathrm{~Hz}), 124.2$ $(\mathrm{d}, J=3.6 \mathrm{~Hz}), 115.4(\mathrm{~d}, J=22.1 \mathrm{~Hz}), 81.4,77.2(\mathrm{q}, J=33.1 \mathrm{~Hz}), 59.7,57.0,56.7,34.0,28.3$. IR $v_{\max } 3039$ (w), 2824 (w), 1704 (s), 1490 (w), 1364 (s), 1286 (m), 1237 (m), 1155 (s), 907 (s). HRMS (ESI) calcd for $\mathrm{C}_{23} \mathrm{H}_{27} \mathrm{~F}_{4} \mathrm{~N}_{2} \mathrm{O}_{2}{ }^{+}[\mathrm{M}+\mathrm{H}]^{+} 439.2003$; found 439.2004. 


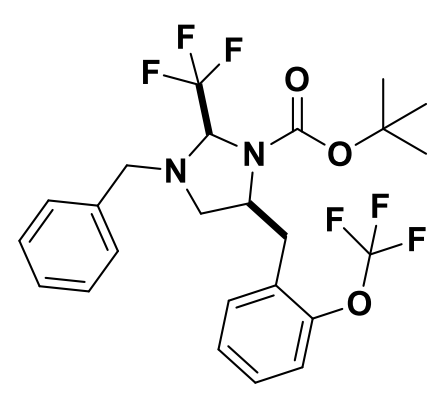

Following General Procedure D, the title compound was prepared from N-benzylprop-2-en-1-amine (1) (44.2 mg, $0.300 \mathrm{mmol}), 1$-((tertbutoxycarbonyl)amino)-2,2,2-trifluoroethyl acetate $(\mathbf{2 a}) \quad(85 \mathrm{mg}$, $0.330 \mathrm{mmol}, 1.1$ equiv) and 1-bromo-2-(trifluoromethoxy)benzene $(67 \mu 1,0.45 \mathrm{mmol}, 1.5 \mathrm{eq})$ at $70{ }^{\circ} \mathrm{C}$. The crude oil $(d r>20: 1$ determined by integration in the crude ${ }^{19} \mathrm{~F}$ NMR of the crude) was purified by column chromatography on Biotage (SNAP cartridge KPSIL $25 \mathrm{~g}, 85: 15$ to $50: 50$ Pentane: $\mathrm{CH}_{2} \mathrm{Cl}_{2}$ ) to afford the title compound 28 (122 mg, $0.242 \mathrm{mmol}, 81 \%$ yield) as a yellow oil.

Rf 0.45 (Pentane: $\mathrm{CH}_{2} \mathrm{Cl}_{2} 5: 7$ ).

${ }^{1} \mathbf{H}$ NMR $\left(400 \mathrm{MHz}, \mathrm{CDCl}_{3}\right) \delta 7.33-7.12(\mathrm{~m}, 9 \mathrm{H}, \mathrm{ArH}), 4.98-4.84\left(\mathrm{~m}, 1 \mathrm{H}, \mathrm{CHCF}_{3}\right), 4.30-$ $4.16(\mathrm{~m}, 1 \mathrm{H}, \mathrm{CHN}), 3.87\left(\mathrm{~d}, J=13.0 \mathrm{~Hz}, 1 \mathrm{H}, \mathrm{CH}_{2} \mathrm{Ph}\right), 3.71\left(\mathrm{~d}, J=13.0 \mathrm{~Hz}, 1 \mathrm{H}, \mathrm{CH}_{2} \mathrm{Ph}\right), 3.31-$ $3.20\left(\mathrm{~m}, 1 \mathrm{H}, \mathrm{CH}_{2} \mathrm{Ar}\right), 3.11-3.01\left(\mathrm{~m}, 1 \mathrm{H}, \mathrm{CH}_{2} \mathrm{~N}\right), 2.92-2.80\left(\mathrm{~m}, 2 \mathrm{H}, \mathrm{CH}_{2} \mathrm{Ar}\right.$ and $\left.\mathrm{CH}_{2} \mathrm{~N}\right), 1.43$ (s, 9H, Boc).

${ }^{13}$ C NMR $\left(101 \mathrm{MHz}, \mathrm{CDCl}_{3}\right) \delta 154.3,147.8,137.3,131.9,130.5,128.6,128.5,127.9,127.7$, 126.7, $124.3(\mathrm{q}, J=284.7 \mathrm{~Hz}), 120.5(\mathrm{q}, J=257.5 \mathrm{~Hz}), 120.2,81.3,77.2$ (m overlapping with chloroform signals), 59.7, 56.9, 56.5, 34.2, 28.1 .

${ }^{19}$ F NMR (376 MHz, Chloroform-d) $\delta$-56.89, -76.21.

IR $v_{\max } 3067(\mathrm{w}), 2821(\mathrm{w}), 1710$ (m), 1490 (w), 1455 (w), 1367 (m), 1258 (s), 1170 (s), 917 (w). HRMS (ESI) calcd for $\mathrm{C}_{24} \mathrm{H}_{27} \mathrm{~F}_{6} \mathrm{~N}_{2} \mathrm{O}_{3}{ }^{+}[\mathrm{M}+\mathrm{H}]^{+}$505.1920; found 505.1924.

Tert-butyl 3-benzyl-5-(2-bromobenzyl)-2-(trifluoromethyl)imidazolidine-1-carboxylate (29)

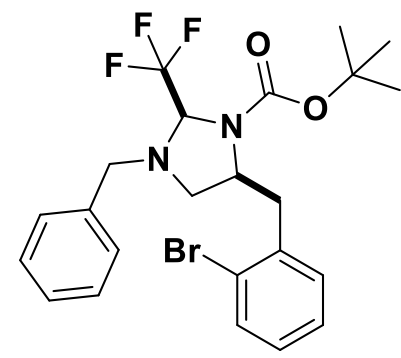

Following General Procedure D, the title compound was prepared from N-benzylprop-2-en-1-amine (1) (44.2 $\mathrm{mg}, 0.300 \mathrm{mmol}), \quad 1-(($ tertbutoxycarbonyl)amino)-2,2,2-trifluoroethyl acetate (2a) (85 $\mathrm{mg}, 0.33$ mmol, 1.1 equiv) and 1,2-dibromobenzene ( $54 \mu \mathrm{L}, 0.45 \mathrm{mmol}, 1.5 \mathrm{eq})$ at $70{ }^{\circ} \mathrm{C}$. The crude oil $\left(d r>20: 1\right.$ determined by integration in the ${ }^{19} \mathrm{~F}$ NMR of the crude) was purified by column chromatography on Biotage (SNAP cartridge KP-SIL $25 \mathrm{~g}, 85: 15$ to $50: 50$ Pentane: $\mathrm{CH}_{2} \mathrm{Cl}_{2}$ ) to afford the title compound $29(95.0 \mathrm{mg}, 0.190 \mathrm{mmol}, 63 \%$ yield) as a

yellow oil.

$\mathbf{R}_{\mathbf{f}} 0.40$ (Pentane: $\mathrm{CH}_{2} \mathrm{Cl}_{2}$ 5:7).

${ }^{1} \mathbf{H}$ NMR $\left(400 \mathrm{MHz}, \mathrm{CDCl}_{3}\right) \delta 7.51(\mathrm{~d}, J=7.9 \mathrm{~Hz}, 1 \mathrm{H}, \mathrm{ArH}), 7.38-7.22(\mathrm{~m}, 5 \mathrm{H}, \mathrm{ArH}), 7.22-$ $7.16(\mathrm{~m}, 2 \mathrm{H}, \mathrm{ArH}), 7.12-7.03(\mathrm{~m}, 1 \mathrm{H}, \mathrm{ArH}), 5.06-4.79\left(\mathrm{~m}, 1 \mathrm{H}, \mathrm{CHCF}_{3}\right), 4.45-4.29(\mathrm{~m}, 1 \mathrm{H}$, $\mathrm{CHN}), 4.02-3.83\left(\mathrm{~m}, 1 \mathrm{H}, \mathrm{CH}_{2} \mathrm{Ph}\right), 3.77-3.66\left(\mathrm{~m}, 1 \mathrm{H}, \mathrm{CH}_{2} \mathrm{Ph}\right), 3.44-3.22\left(\mathrm{~m}, 1 \mathrm{H}, \mathrm{CH}_{2} \mathrm{Ar}\right)$, $3.22-3.05\left(\mathrm{~m}, 1 \mathrm{H}, \mathrm{CH}_{2} \mathrm{~N}\right), 3.00-2.88\left(\mathrm{~m}, 1 \mathrm{H}, \mathrm{CH}_{2} \mathrm{Ar}\right), 2.88-2.75\left(\mathrm{~m}, 1 \mathrm{H}, \mathrm{CH}_{2} \mathrm{~N}\right), 1.40(\mathrm{~s}, 9 \mathrm{H}$, Boc).

${ }^{13}$ C NMR (101 MHz, $\left.\mathrm{CDCl}_{3}\right) \delta 154.3,137.6,137.4,132.7,131.7,128.6,128.5,128.1,127.6$, $127.4,124.7,124.3(\mathrm{q}, J=284.7 \mathrm{~Hz}), 81.2,77.2$ (m overlapping with chloroform signals), 59.6, 56.4, 56.2, 39.9, 28.2.

${ }^{19}$ F NMR (376 MHz, Chloroform- $d$ ) $\delta$-75.9.

IR $v_{\max } 3065(\mathrm{w}), 2823(\mathrm{w}), 1709(\mathrm{~s}), 1452(\mathrm{w}), 1365$ (s), $1286(\mathrm{~m}), 1170(\mathrm{~s}), 914(\mathrm{~m})$. 
HRMS (ESI) calcd for $\mathrm{C}_{23} \mathrm{H}_{27}{ }^{79} \mathrm{BrF}_{3} \mathrm{~N}_{2} \mathrm{O}_{2}{ }^{+}[\mathrm{M}+\mathrm{H}]^{+} 499.1202$; found 499.1193 .

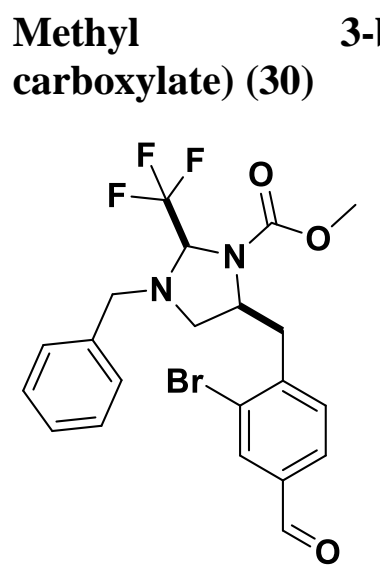

3-benzyl-5-(2-bromo-4-formylbenzyl)-2-(trifluoromethyl)imidazolidine-1carboxylate) (30)

$\mathbf{R}_{\mathbf{f}} 0.30$ (Pentane: $\mathrm{Et}_{2} \mathrm{O} 1: 1$ ).

${ }^{1} \mathbf{H}$ NMR (400 MHz, $\left.\mathrm{CDCl}_{3}\right) \delta 9.91$ (s, 1H, CHO), $8.08-7.99(\mathrm{~m}, 1 \mathrm{H}, \mathrm{ArH}), 7.74-7.66(\mathrm{~m}, 1 \mathrm{H}$, $\mathrm{ArH}), 7.37-7.27(\mathrm{~m}, 6 \mathrm{H}, \mathrm{ArH}), 5.04-4.89\left(\mathrm{~m}, 1 \mathrm{H}, \mathrm{CHCF}_{3}\right), 4.46-4.34(\mathrm{~m}, 1 \mathrm{H}, \mathrm{CHN}), 3.91$ $\left(\mathrm{d}, J=13.3 \mathrm{~Hz}, 1 \mathrm{H}, \mathrm{CH}_{2} \mathrm{Ph}\right), 3.73\left(\mathrm{~d}, J=13.3 \mathrm{~Hz}, 1 \mathrm{H}, \mathrm{CH}_{2} \mathrm{Ph}\right), 3.64(\mathrm{~s}, 3 \mathrm{H}, \mathrm{Me}), 3.52-3.30(\mathrm{~m}$, $\left.1 \mathrm{H}, \mathrm{CH}_{2} \mathrm{Ar}\right), 3.15\left(\mathrm{dd}, J=11.6,6.7 \mathrm{~Hz}, 1 \mathrm{H}, \mathrm{CH}_{2} \mathrm{~N}\right), 3.01\left(\mathrm{dd}, J=13.2,8.0 \mathrm{~Hz}, 1 \mathrm{H}, \mathrm{CH}_{2} \mathrm{Ar}\right), 2.92$ (dd, $J=11.6,7.5 \mathrm{~Hz}, 1 \mathrm{H}, \mathrm{CH}_{2} \mathrm{~N}$ ).

${ }^{13}$ C NMR $\left(101 \mathrm{MHz}, \mathrm{CDCl}_{3}\right) \delta 190.5,155.9,144.5,137.2,136.5,133.9,132.2,128.7$ (2C), 128.6, 128.0, 125.7, $124.2(\mathrm{~d}, J=284.0 \mathrm{~Hz}$ ), 77.2 (m overlapping with chloroform signal), 59.7, 56.5 (2C), 53.3, 40.5 .

IR $v_{\max } 2973(\mathrm{~m}), 1713(\mathrm{~s}), 1598(\mathrm{w}), 1453$ (m), 1369 (s), 1181 (s), 1139 (s), 1068 (m).

HRMS (ESI) calcd for $\mathrm{C}_{21} \mathrm{H}_{20}{ }^{79} \mathrm{BrF}_{3} \mathrm{~N}_{2} \mathrm{NaO}_{3}{ }^{+}[\mathrm{M}+\mathrm{Na}]^{+}$507.0502; found 507.0500.

\section{Tert-butyl 3-benzyl-5-(4-(methoxycarbonyl)benzyl)-2-(trifluoromethyl)imidazolidine-1- carboxylate (31)}

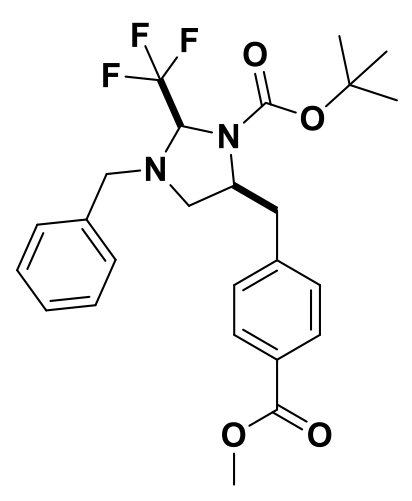

Following General Procedure $\mathbf{D}$, the title compound was prepared from N-benzylprop-2-en-1-amine (1) $(44.2 \mathrm{mg}, 0.300 \mathrm{mmol})$, 1-((tertbutoxycarbonyl)amino)-2,2,2-trifluoroethyl acetate (2a) (85 $\mathrm{mg}, 0.330$ mmol, 1.1 equiv) and methyl 4-bromobenzoate $(97 \mathrm{mg}, 0.45 \mathrm{mmol}, 1.5$ equiv) at $70^{\circ} \mathrm{C}$. The crude oil ( $d r>20$ determined by integration in the crude ${ }^{1} \mathrm{H}$ NMR) was purified by column chromatography on Biotage (SNAP cartridge KP-SIL $25 \mathrm{~g}$, 95:15 to 75:25 Pentane:Et $2 \mathrm{O}$ ) affording the title compound $\mathbf{3 1}(107 \mathrm{mg}, 0.224 \mathrm{mmol}, 75 \%$ yield) as a yellow oil.

\section{Rf 0.35 (Pentane: $\mathrm{Et}_{2} \mathrm{O} 4: 1$ ).}

${ }^{1} \mathbf{H}$ NMR $\left(400 \mathrm{MHz}, \mathrm{CDCl}_{3}\right) \delta 7.96-7.91(\mathrm{~m}, 2 \mathrm{H}, \mathrm{ArH}), 7.35-7.19(\mathrm{~m}, 7 \mathrm{H}, \mathrm{ArH}), 5.07-4.76$ $\left(\mathrm{m}, 1 \mathrm{H}, \mathrm{CHCF}_{3}\right), 4.23-4.04(\mathrm{~m}, 1 \mathrm{H}, \mathrm{CHN}), 3.89(\mathrm{~s}, 3 \mathrm{H}, \mathrm{Me}), 3.88-3.78\left(\mathrm{~m}, 1 \mathrm{H}, \mathrm{CH}_{2} \mathrm{Ph}\right), 3.72$ (d, $\left.J=13.2 \mathrm{~Hz}, 1 \mathrm{H}, \mathrm{CH}_{2} \mathrm{Ph}\right), 3.51-3.31\left(\mathrm{~m}, 1 \mathrm{H}, \mathrm{CH}_{2} \mathrm{Ar}\right), 3.07$ (ddd, $J=11.6,7.1,1.4 \mathrm{~Hz}, 1 \mathrm{H}$, $\left.\mathrm{CH}_{2} \mathrm{~N}\right), 2.88-2.80\left(\mathrm{~m}, 1 \mathrm{H}, \mathrm{CH}_{2} \mathrm{~N}\right), 2.67$ (dd, $\left.J=13.0,9.6 \mathrm{~Hz}, 1 \mathrm{H}, \mathrm{CH}_{2} \mathrm{Ar}\right), 1.48$ (s, 9H, Boc).

${ }^{13} \mathrm{C}$ NMR $\left(101 \mathrm{MHz}, \mathrm{CDCl}_{3}\right) \delta 167.0,154.3,143.5,137.4,130.0,129.3,128.7$ (2C), 128.6, $127.9,124.4(\mathrm{q}, J=284.8 \mathrm{~Hz}) 81.6,77.1(\mathrm{q}, J=33.1 \mathrm{~Hz}), 59.7,58.0,56.4,52.1,40.2,28.3$. 
IR $v_{\max } 3036(\mathrm{w}), 2943(\mathrm{w}), 2837(\mathrm{w}), 1711(\mathrm{~s}), 1611(\mathrm{w}), 1445(\mathrm{w}), 1366(\mathrm{~s}), 1280$ (s), $1156(\mathrm{~s})$, $1115(\mathrm{~s}), 965(\mathrm{~m}), 874(\mathrm{~m})$.

HRMS (ESI) calcd for $\mathrm{C}_{25} \mathrm{H}_{30} \mathrm{~F}_{3} \mathrm{~N}_{2} \mathrm{O}_{4}{ }^{+}[\mathrm{M}+\mathrm{H}]^{+} 479.2152$; found 479.2143.

Tert-butyl 3-benzyl-5-(4-cyanobenzyl)-2-(trifluoromethyl)imidazolidine-1-carboxylate (32)

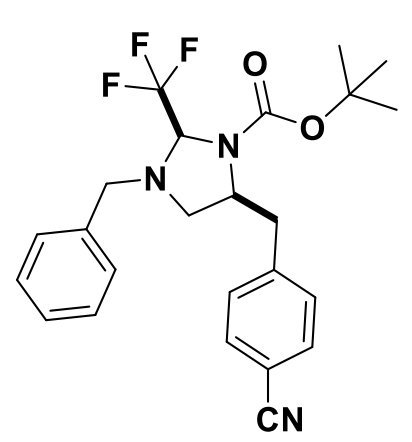

Following General Procedure D, the title compound was prepared from N-benzylprop-2-en-1-amine (1) (44.2 $\mathrm{mg}, 0.300 \mathrm{mmol}), \quad 1$-((tertbutoxycarbonyl)amino)-2,2,2-trifluoroethyl acetate (2a) (85 $\mathrm{mg}, 0.33$ mmol, 1.1 equiv) and 4-bromobenzonitrile $(82 \mathrm{mg}, 0.45 \mathrm{mmol}, 1.5$ equiv) at $70{ }^{\circ} \mathrm{C}$. The crude oil (>20:1 dr determined by integration of $\mathrm{PhCH}_{2} \mathrm{~N}$ peaks in the ${ }^{1} \mathrm{H}$ NMR) was purified by column chromatography on Biotage ((SNAP cartridge KP-SIL $25 \mathrm{~g}$, 95:15 to 70:30 Pentane:Et $\left.{ }_{2} \mathrm{O}\right)$ affording the title compound 32 (114 mg, 0.256 mmol, $85 \%$ yield) as a yellow oil.

$\mathbf{R}_{\mathbf{f}} 0.30$ (Pentane: $\mathrm{Et}_{2} \mathrm{O} 4: 1$ ).

${ }^{1} \mathbf{H}$ NMR $\left(400 \mathrm{MHz}, \mathrm{CDCl}_{3}\right) \delta 7.58-7.46(\mathrm{~m}, 2 \mathrm{H}, \mathrm{ArH}), 7.36-7.17$ (m, 7H, ArH), $4.96-4.82$ $\left(\mathrm{m}, 1 \mathrm{H}, \mathrm{CHCF}_{3}\right), 4.24-4.08(\mathrm{~m}, 1 \mathrm{H}, \mathrm{CHN}), 3.88\left(\mathrm{~d}, J=13.1 \mathrm{~Hz}, 1 \mathrm{H}, \mathrm{CH}_{2} \mathrm{Ph}\right), 3.73(\mathrm{~d}, J=13.1$ $\left.\mathrm{Hz}, 1 \mathrm{H}, \mathrm{CH}_{2} \mathrm{Ph}\right), 3.40-3.28\left(\mathrm{~m}, 1 \mathrm{H}, \mathrm{CH}_{2} \mathrm{Ar}\right), 3.08-2.97\left(\mathrm{~m}, 1 \mathrm{H}, \mathrm{CH}_{2} \mathrm{~N}\right), 2.91-2.81(\mathrm{~m}, 1 \mathrm{H}$, $\left.\mathrm{CH}_{2} \mathrm{~N}\right), 2.79-2.66\left(\mathrm{~m}, 1 \mathrm{H}, \mathrm{CH}_{2} \mathrm{Ar}\right), 1.46$ (s, 9H, Boc).

${ }^{13}$ C NMR $\left(101 \mathrm{MHz}, \mathrm{CDCl}_{3}\right) \delta 154.1,143.6,137.2,132.3,130.0,128.6(2 \mathrm{C}), 127.8,124.2$ (q, $J$ $=284.2 \mathrm{~Hz}$ ), 118.9, 110.5, 81.6, 77.1 (m overlapping with chloroform signal), 59.6, 57.7, 56.3, 40.3, 28.2.

${ }^{19}$ F NMR (376 MHz, Chloroform-d) $\delta$-76.2.

IR $v_{\max } 2979(\mathrm{~s}), 2898(\mathrm{~m}), 1707(\mathrm{~m}), 1376(\mathrm{~m}), 1247(\mathrm{w}), 1166(\mathrm{~m}), 1067$ (s), $879(\mathrm{w})$.

HRMS (ESI) calcd for $\mathrm{C}_{24} \mathrm{H}_{27} \mathrm{~F}_{3} \mathrm{~N}_{3} \mathrm{O}_{2}{ }^{+}[\mathrm{M}+\mathrm{H}]^{+}$446.2050; found 446.2060.

\section{Methyl 3-benzyl-5-(3,5-bis(trifluoromethyl)benzyl)-2-(trifluoromethyl)imidazolidine-1- carboxylate (33)}

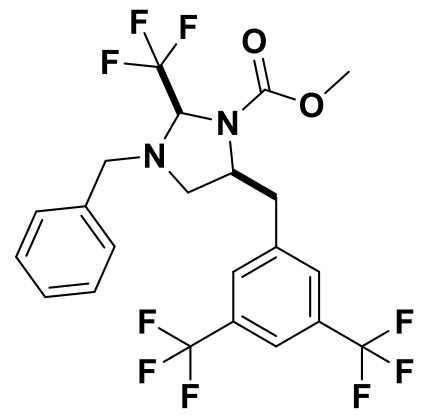

Following General Procedure D, the title compound was prepared from N-benzylprop-2-en-1-amine (1) (44.2 mg, $0.300 \mathrm{mmol}), 2,2,2$ trifluoro-1-((methoxycarbonyl)amino)ethyl acetate (2aa) $(71 \mathrm{mg}, 0.33$ mmol, 1.1 equiv) and 1-bromo-3,5-bis(trifluoromethyl)benzene (77 $\mu 1$, $0.45 \mathrm{mmol}, 1.5$ equiv) at $70{ }^{\circ} \mathrm{C}$. The crude oil $(d r>20$ determined by integration in the crude ${ }^{19} \mathrm{~F}$ NMR) was purified by column chromatography on Biotage (SNAP cartridge KP-SIL $25 \mathrm{~g}$, 85:15 to 40:60 Pentane: $\mathrm{CH}_{2} \mathrm{Cl}_{2}$ ) affording the title compound 33 (152 $\mathrm{mg}$, $0.295 \mathrm{mmol}, 98 \%$ yield) as a yellow oil.

Rf 0.50 (Pentane: $\mathrm{CH}_{2} \mathrm{Cl}_{2} 5: 7$ ).

${ }^{1} \mathbf{H}$ NMR $\left(400 \mathrm{MHz}, \mathrm{CDCl}_{3}\right) \delta 7.75(\mathrm{~s}, 1 \mathrm{H}, \mathrm{ArH}), 7.63(\mathrm{~s}, 2 \mathrm{H}, \mathrm{ArH}), 7.39-7.27$ (m, 5H, $\left.\mathrm{ArH}\right)$, $5.08-4.89\left(\mathrm{~m}, 1 \mathrm{H}, \mathrm{CHCF}_{3}\right), 4.29-4.13(\mathrm{~m}, 1 \mathrm{H}, \mathrm{CHN}), 3.92\left(\mathrm{~d}, J=13.4 \mathrm{~Hz}, 1 \mathrm{H}, \mathrm{CH}_{2} \mathrm{Ph}\right), 3.76$ $\left(\mathrm{d}, J=13.5 \mathrm{~Hz}, 2 \mathrm{H}, \mathrm{CH}_{2} \mathrm{Ph}\right), 3.73$ (s, 3H, Me), $3.47-3.34$ (m, 1H, $\mathrm{CH}_{2} \mathrm{Ar}$ ), 3.09 (dd, $J=11.6$, $\left.6.8 \mathrm{~Hz}, 1 \mathrm{H}, \mathrm{CH}_{2} \mathrm{~N}\right), 2.98-2.91\left(\mathrm{~m}, 1 \mathrm{H}, \mathrm{CH}_{2} \mathrm{~N}\right), 2.88\left(\mathrm{dd}, J=13.5,8.7 \mathrm{~Hz}, 1 \mathrm{H}, \mathrm{CH}_{2} \mathrm{Ar}\right)$. 
${ }^{13} \mathrm{C}$ NMR $\left(101 \mathrm{MHz}, \mathrm{CDCl}_{3}\right) \delta 155.8,140.3,137.1,131.9(\mathrm{q}, J=33.2 \mathrm{~Hz}), 129.5,128.8,128.7$, 128.1, $124.2(\mathrm{q}, J=284.4 \mathrm{~Hz}), 123.4(\mathrm{q}, J=272.7 \mathrm{~Hz}), 121.04-120.63(\mathrm{~m}), 77.2(\mathrm{~m}$ overlapping with chloroform signals), 59.6, 58.0, 56.3, 53.4, 39.6.

${ }^{19}$ F NMR $\left(376 \mathrm{MHz}, \mathrm{CDCl}_{3}\right) \delta-62.9,-76.5$.

IR $v_{\max } 2965(\mathrm{w}), 2901(\mathrm{w}), 1718(\mathrm{~m}), 1451(\mathrm{w}), 1376$ (m), 1282 (s), 1175 (s), 1137 (s), 906 (m). HRMS (ESI) calcd for $\mathrm{C}_{22} \mathrm{H}_{19} \mathrm{~F}_{9} \mathrm{~N}_{2} \mathrm{NaO}_{2}{ }^{+}[\mathrm{M}+\mathrm{Na}]^{+}$537.1195; found 537.1190.

\section{Tert-butyl 3-benzyl-5-(3,5-bis(trifluoromethyl)benzyl)-5-methyl-2- (trifluoromethyl)imidazolidine-1-carboxylate (34)}

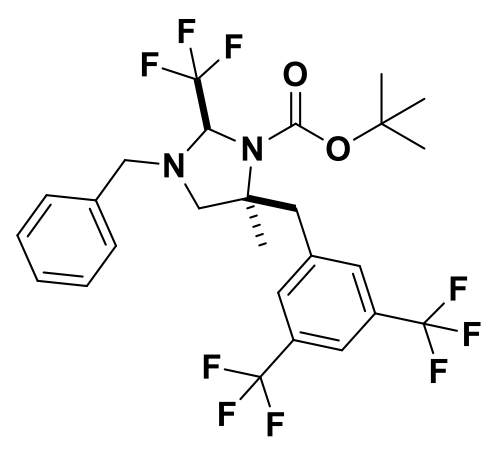

Following General Procedure $\mathbf{C}$, the title compound was prepared from N-benzyl-2-methylprop-2-en-1-amine (45) (48.4 mg, 0.300 $\mathrm{mmol})$ and 1-((tert-butoxycarbonyl)amino)-2,2,2-trifluoroethyl acetate (2a) (85 mg, $0.33 \mathrm{mmol}, 1.1$ equiv), 1-bromo-3,5bis(trifluoromethyl)benzene $(77 \mu \mathrm{l}, 0.45 \mathrm{mmol}, 1.5$ equiv) at 70 ${ }^{\circ} \mathrm{C}$. The crude oil $(d r>20$ determined by integration in the crude ${ }^{1} \mathrm{H}$ NMR) was purified by column chromatography on Biotage (SNAP cartridge KP-SIL $25 \mathrm{~g}$, 90:10 to 60:40 Pentane: $\mathrm{CH}_{2} \mathrm{Cl}_{2}$ ) affording the title compound 34 (152 mg, $0.266 \mathrm{mmol}, 89 \%$ yield) as a yellow oil.

Rf 0.70 (Pentane: $\mathrm{CH}_{2} \mathrm{Cl}_{2} 5: 7$ ).

${ }^{1} \mathbf{H}$ NMR $\left(400 \mathrm{MHz}, \mathrm{CDCl}_{3}\right) \delta 7.75(\mathrm{~s}, 1 \mathrm{H}, \operatorname{Ar} H), 7.63(\mathrm{~s}, 2 \mathrm{H}, \mathrm{ArH}), 7.37-7.25(\mathrm{~m}, 5 \mathrm{H}, \operatorname{ArH})$, $5.04-4.91\left(\mathrm{~m}, 1 \mathrm{H}, \mathrm{CHCF}_{3}\right), 4.01\left(\mathrm{~d}, J=13.6 \mathrm{~Hz}, 1 \mathrm{H}, \mathrm{CH}_{2} \mathrm{Ph}\right), 3.85(\mathrm{~d}, J=13.6 \mathrm{~Hz}, 1 \mathrm{H}$, $\left.\mathrm{CH}_{2} \mathrm{Ph}\right), 3.63-3.47\left(\mathrm{~m}, 1 \mathrm{H}, \mathrm{CH}_{2} \mathrm{Ar}\right), 3.14\left(\mathrm{~d}, J=10.4 \mathrm{~Hz}, 1 \mathrm{H}, \mathrm{CH}_{2} \mathrm{~N}\right), 2.93(\mathrm{~d}, J=13.7 \mathrm{~Hz}, 1 \mathrm{H}$, $\left.\mathrm{CH}_{2} \mathrm{Ar}\right), 2.69\left(\mathrm{dd}, J=10.3,1.6 \mathrm{~Hz}, 1 \mathrm{H}, \mathrm{CH}_{2} \mathrm{~N}\right), 1.61$ (s, 3H, Me), 1.53 (s, 9H, Boc).

${ }^{13} \mathrm{C}$ NMR $\left(101 \mathrm{MHz}, \mathrm{CDCl}_{3}\right) \delta 153.1,139.4,137.8,131.3(\mathrm{q}, J=33.0 \mathrm{~Hz}), 130.9,128.7,128.4$, $127.8,124.1(\mathrm{q}, J=292.5 \mathrm{~Hz}), 123.6(\mathrm{q}, J=272.5 \mathrm{~Hz}), 120.7(\mathrm{~m}), 81.9,76.4(\mathrm{q}, J=31.3 \mathrm{~Hz})$, 64.0, 58.6, 56.5, 42.5, 28.2, 25.2.

IR $v_{\max } 2986(\mathrm{w}), 2865(\mathrm{w}), 1704(\mathrm{~m}), 1461(\mathrm{w}), 1365$ (m), 1277 (s), 1166 (s), 1132 (s), $904(\mathrm{~m})$. HRMS (ESI) calcd for $\mathrm{C}_{26} \mathrm{H}_{28} \mathrm{~F}_{9} \mathrm{~N}_{2} \mathrm{O}_{2}{ }^{+}[\mathrm{M}+\mathrm{H}]^{+}$571.2002; found 571.1998.

Tert-butyl 3-benzyl-5-((3-fluoropyridin-2-yl)methyl)-2-(trifluoromethyl)imidazolidine-1carboxylate (35)

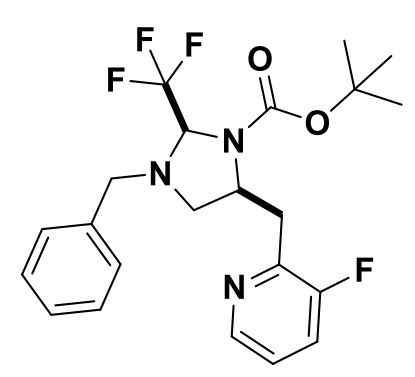

Following General Procedure D with DPEPhos (19 mg, $0.036 \mathrm{mmol})$ as ligand, the title compound was prepared from N-benzylprop-2-en-1amine (1) (44.2 $\mathrm{mg}, 0.300 \mathrm{mmol}), 1-(($ tert-butoxycarbonyl)amino)2,2,2-trifluoroethyl acetate (2a) (85 $\mathrm{mg}, 0.330 \mathrm{mmol}, 1.1$ equiv) and 2bromo-3-fluoropyridine ( $79 \mathrm{mg}, 0.45 \mathrm{mmol}, 1.5$ equiv) at $70{ }^{\circ} \mathrm{C}$. The crude oil ( $>20: 1 \mathrm{dr}$ determined by integration of $\mathrm{PhCH}_{2} \mathrm{~N}$ peaks in the ${ }^{1} \mathrm{H}$ NMR) was purified by column chromatography on Biotage (SNAP cartridge KP-SIL $25 \mathrm{~g}$, 96:4 to 75:25 Pentane:EtOAc) affording the title compound 35 (88 mg, $0.20 \mathrm{mmol}, 67 \%$ yield) as a yellow oil.

$\mathbf{R}_{\mathbf{f}} 0.25$ (Pentane:EtOAc 5:1). 
${ }^{1} \mathbf{H}$ NMR $\left(400 \mathrm{MHz}, \mathrm{CDCl}_{3}\right) \delta 8.2(\mathrm{dt}, J=4.7,1.5 \mathrm{~Hz}, 1 \mathrm{H}, \operatorname{HetAr} H), 7.26-7.16(\mathrm{~m}, 6 \mathrm{H}, \operatorname{Ar} H)$, $7.08-7.02\left(\mathrm{~m}, 1 \mathrm{H}\right.$, HetArH), $5.01-4.67\left(\mathrm{~m}, 1 \mathrm{H}, \mathrm{CF}_{3} \mathrm{CH}\right), 4.54-4.23(\mathrm{~m}, 1 \mathrm{H}, \mathrm{NCH}), 3.79-$ $3.67\left(\mathrm{~m}, 2 \mathrm{H}, \mathrm{PhCH}_{2}\right), 3.53-3.43\left(\mathrm{~m}, 1 \mathrm{H}\right.$, HetArCH$\left.H_{2}\right), 3.18-3.09$ (m, 1H, NCH$), 3.09-2.98$ (m, $\left.1 \mathrm{H}, \mathrm{NCH}_{2}\right), 2.97-2.87$ (m, 1H, HetArCH$H_{2}, 1.39$ (s, 9H, Boc).

${ }^{13}$ C NMR $\left(101 \mathrm{MHz}, \mathrm{CDCl}_{3}\right) \delta 158.1(\mathrm{~d}, J=256.8 \mathrm{~Hz}), 154.5,146.9(\mathrm{~d}, J=15.6 \mathrm{~Hz}), 145.0(\mathrm{~d}, J$ $=5.4 \mathrm{~Hz}), 137.6,128.8,128.6,127.8,124.3(\mathrm{q}, J=284.5 \mathrm{~Hz}), 122.9,122.5(\mathrm{~d}, J=19.4 \mathrm{~Hz})$, 81.4, 77.2 (q, $J=33.2 \mathrm{~Hz}), 59.9,57.2,55.6,35.7,28.3$.

IR $v_{\max } 3068(\mathrm{w}), 2827(\mathrm{w}), 1707$ (s), $1454(\mathrm{~m}), 1366(\mathrm{~s}), 1285$ (m), 1248 (m), 1173 (s), $964(\mathrm{w})$, 909 (s).

HRMS (ESI) calcd for $\mathrm{C}_{22} \mathrm{H}_{26} \mathrm{~F}_{4} \mathrm{~N}_{3} \mathrm{O}_{2}{ }^{+}[\mathrm{M}+\mathrm{H}]^{+} 440.1956$; found 440.1951.

\section{Methyl 3-benzyl-5-((2-chloropyrimidin-5-yl)methyl)-2-(trifluoromethyl)imidazolidine-1- carboxylate (36)}

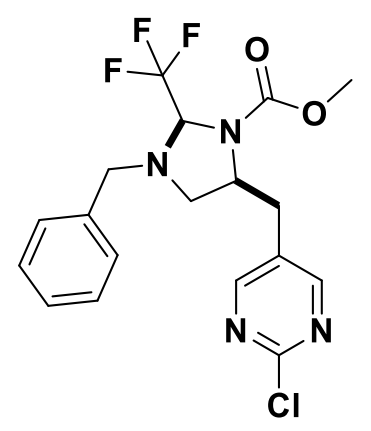

Following General Procedure D, the title compound was prepared from Nbenzylprop-2-en-1-amine (1) (44.2 mg, $0.300 \mathrm{mmol}$ ), 2,2,2-trifluoro-1((methoxycarbonyl)amino)ethyl acetate (2aa) $(71 \mathrm{mg}, 0.33 \mathrm{mmol}, 1.1$ equiv) and 5-bromo-2-chloropyrimidine (87.0 $\mathrm{mg}, 0.450 \mathrm{mmol}, 1.5$ equiv) at $70{ }^{\circ} \mathrm{C}$. The crude oil (>20:1 dr determined by integration of $\mathrm{PhCH}_{2} \mathrm{~N}$ peaks in the ${ }^{1} \mathrm{H} \mathrm{NMR}$ ) was purified by column chromatography on Biotage (SNAP cartridge KP-SIL 25 g, 80:20 to 20:80 Pentane:Et ${ }_{2} \mathrm{O}$ ) affording the title compound 36 (112 $\mathrm{mg}, 0.270 \mathrm{mmol}, 90 \%$ yield) as a yellow oil.

$\mathbf{R}_{\mathbf{f}} 0.25$ (Pentane: $\mathrm{Et}_{2} \mathrm{O} 5: 1$ ).

${ }^{1} \mathbf{H}$ NMR $\left(400 \mathrm{MHz}, \mathrm{CDCl}_{3}\right) \delta 8.43(\mathrm{~s}, 2 \mathrm{H}, \operatorname{HetArH}), 7.39-7.24(\mathrm{~m}, 5 \mathrm{H}, \mathrm{ArH}), 5.05-4.86(\mathrm{~m}$, $\left.1 \mathrm{H}, \mathrm{CF}_{3} \mathrm{CH}\right), 4.16(\mathrm{q}, J=7.4 \mathrm{~Hz}, 1 \mathrm{H}, \mathrm{NCH}), 3.94\left(\mathrm{~d}, J=13.3 \mathrm{~Hz}, 1 \mathrm{H}, \mathrm{PhCH}_{2}\right), 3.75(\mathrm{~d}, J=13.2$ $\mathrm{Hz}, 1 \mathrm{H}, \mathrm{PhCH}_{2}$ ), 3.70 (s, 3H, Me), 3.17 (dd, $\left.J=14.1,5.9 \mathrm{~Hz}, 1 \mathrm{H}, \mathrm{HetArCH}_{2}\right), 3.07$ - 2.94 (m, $\left.2 \mathrm{H}, \mathrm{NCH}_{2}\right), 2.76(\mathrm{dd}, J=14.0,7.7 \mathrm{~Hz}, 1 \mathrm{H}, \mathrm{HetArCH})_{2}$.

${ }^{13} \mathrm{C}$ NMR $\left(101 \mathrm{MHz}, \mathrm{CDCl}_{3}\right) \delta 160.0,155.6$ (2C), 136.8, 129.7, 128.8, 128.6, 128.1, 124.1 (d, $J$ $=284.4 \mathrm{~Hz}), 77.2(\mathrm{q}, J=33.6 \mathrm{~Hz}), 59.5,57.6,56.1,53.5,33.8$.

IR $v_{\max } 2965(\mathrm{~m}), 2908(\mathrm{w}), 1713(\mathrm{~s}), 1579(\mathrm{w}), 1549(\mathrm{w}), 1448(\mathrm{~m}), 1393(\mathrm{~s}), 1362$ (s), 1283 (m), 1239 (m), 1141 (s), $1072(\mathrm{~m}), 985(\mathrm{w}), 912(\mathrm{w}), 852(\mathrm{w})$.

HRMS (ESI) calcd for $\mathrm{C}_{18} \mathrm{H}_{18} \mathrm{ClF}_{3} \mathrm{~N}_{4} \mathrm{NaO}_{2}{ }^{+}[\mathrm{M}+\mathrm{Na}]^{+} 437.0963$; found 437.0958.

\section{Methyl 3-benzyl-5-((5-nitrofuran-2-yl)methyl)-2-(trifluoromethyl)imidazolidine-1- carboxylate (37)}

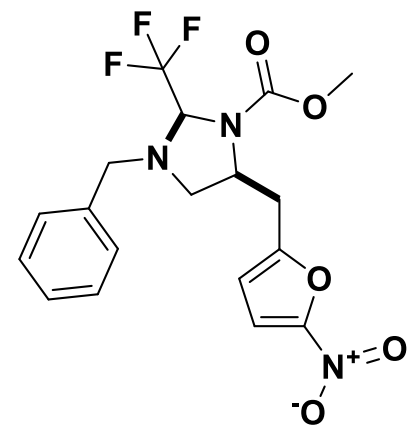

Following General Procedure D, the title compound was prepared from N-benzylprop-2-en-1-amine (1) (44.2 mg, 0.300 mmol), 2,2,2trifluoro-1-((methoxycarbonyl)amino)ethyl acetate (2aa) $(71 \mathrm{mg}, 0.33$ mmol, 1.1 equiv) and 2-bromo-5-nitrofuran ( $86 \mathrm{mg}, 0.45 \mathrm{mmol}, 1.5$ equiv) at $70{ }^{\circ} \mathrm{C}$. The crude oil (>20:1 dr determined by integration of $\mathrm{PhCH}_{2} \mathrm{~N}$ peaks in the ${ }^{1} \mathrm{H}$ NMR) was purified by column chromatography on Biotage (SNAP cartridge KP-SIL $25 \mathrm{~g}$, 80:20 to 40:60 Pentane:Et ${ }_{2} \mathrm{O}$ ) affording the title compound 37 (101 mg, 0.244 mmol, $81 \%$ yield) as a yellow oil. 
$\mathbf{R}_{\mathbf{f}} 0.20$ (Pentane: $\mathrm{Et}_{2} \mathrm{O} 2: 1$ ).

${ }^{1} \mathbf{H}$ NMR $\left(400 \mathrm{MHz}, \mathrm{CDCl}_{3}\right) \delta 7.37-7.27(\mathrm{~m}, 5 \mathrm{H}, \mathrm{ArH}), 7.21(\mathrm{~d}, J=3.6 \mathrm{~Hz}, 1 \mathrm{H}, \mathrm{HetArH}), 6.31$ $(\mathrm{d}, J=3.6 \mathrm{~Hz}, 1 \mathrm{H}, \operatorname{Het} \mathrm{ArH}), 5.06-4.86\left(\mathrm{~m}, 1 \mathrm{H}, \mathrm{CF}_{3} \mathrm{CH}\right), 4.38-4.26(\mathrm{~m}, 1 \mathrm{H}, \mathrm{NCH}), 3.92(\mathrm{~d}, J$ $\left.=13.6 \mathrm{~Hz}, 1 \mathrm{H}, \mathrm{PhCH}_{2}\right), 3.77\left(\mathrm{~d}, J=13.2 \mathrm{~Hz}, 1 \mathrm{H}, \mathrm{PhCH}_{2}\right), 3.71(\mathrm{~s}, 3 \mathrm{H}, \mathrm{Me}), 3.32(\mathrm{~d}, J=12.3 \mathrm{~Hz}$, $1 \mathrm{H}$, HetArCH$\left.H_{2}\right), 3.21-3.05\left(\mathrm{~m}, 2 \mathrm{H}, \mathrm{NCH}_{2}\right), 2.88$ (dd, $\left.J=15.0,8.1 \mathrm{~Hz}, 1 \mathrm{H}, \mathrm{HetArCH}_{2}\right)$.

${ }^{13} \mathrm{C}$ NMR $\left(101 \mathrm{MHz}, \mathrm{CDCl}_{3}\right) \delta 156.2,155.6,151.9,136.9,128.8,128.7,128.0,124.1(\mathrm{q}, J=$ 284.3 Hz), 112.8, 111.3, 77.1 (m overlapping with chloroform signal), 59.6, 56.6, 55.5, 53.5, 32.8 .

IR $v_{\max } 3141(\mathrm{w}), 2983(\mathrm{w}), 2962(\mathrm{w}), 2902(\mathrm{w}), 1711(\mathrm{~m}), 1591(\mathrm{w}), 1529(\mathrm{w}), 1498(\mathrm{~m}), 1448$ (w), $1359(\mathrm{~m}), 1330(\mathrm{w}), 1285(\mathrm{w}), 1236(\mathrm{w}), 1145(\mathrm{~m}), 1074(\mathrm{w}), 1025(\mathrm{w}), 908(\mathrm{~s})$.

HRMS (ESI) calcd for $\mathrm{C}_{18} \mathrm{H}_{18} \mathrm{~F}_{3} \mathrm{~N}_{3} \mathrm{NaO}_{5}{ }^{+}[\mathrm{M}+\mathrm{Na}]^{+} 436.1091$; found 436.1081.

\section{Methyl 5-((5-benzoylthiophen-2-yl)methyl)-3-benzyl-2-(trifluoromethyl)imidazolidine-1- carboxylate (38)}

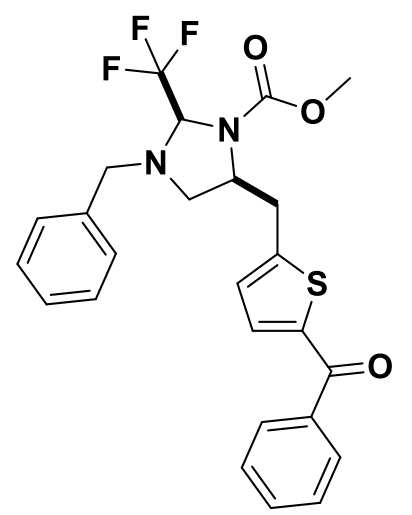

Following General Procedure D, the title compound was prepared from N-benzylprop-2-en-1-amine (1) (44.2 mg, $0.300 \mathrm{mmol}), 2$,2,2-trifluoro1-((methoxycarbonyl)amino)ethyl acetate (2aa) $(71 \mathrm{mg}, 0.33 \mathrm{mmol}, 1.1$ equiv) and (5-bromothiophen-2-yl)(phenyl)methanone (120 mg, 0.450 mmol, 1.5 equiv) at $70{ }^{\circ} \mathrm{C}$. The crude oil $(>20: 1 \mathrm{dr}$ determined by integration of $\mathrm{PhCH}_{2} \mathrm{~N}$ peaks in the ${ }^{1} \mathrm{H}$ NMR) was purified by column chromatography on Biotage (SNAP cartridge KP-SIL $25 \mathrm{~g}$, 90:20 to 50:50 Pentane:Et $\left.{ }_{2} \mathrm{O}\right)$ affording the title compound $38(120 \mathrm{mg}, 0.246$ mmol, $82 \%$ yield, $95 \%$ purity) as a yellow oil.

$\mathbf{R}_{\mathbf{f}} 0.50$ (Pentane: $\mathrm{Et}_{2} \mathrm{O} 1: 1$ ).

${ }^{1} \mathbf{H}$ NMR $\left(400 \mathrm{MHz}, \mathrm{CDCl}_{3}\right) \delta 7.85-7.78(\mathrm{~m}, 2 \mathrm{H}, \mathrm{ArH}), 7.62-7.54(\mathrm{~m}, 1 \mathrm{H}, \mathrm{ArH}), 7.52-7.43$ $(\mathrm{m}, 3 \mathrm{H}, \mathrm{ArH}), 7.38-7.22(\mathrm{~m}, 5 \mathrm{H}, \mathrm{ArH}), 6.92-6.80(\mathrm{~m}, 1 \mathrm{H}, \mathrm{ArH}), 5.16-4.79\left(\mathrm{~m}, 1 \mathrm{H}, \mathrm{CF}_{3} \mathrm{CH}\right)$, $4.33-4.12(\mathrm{~m}, 1 \mathrm{H}, \mathrm{NCH}), 3.88\left(\mathrm{~d}, J=13.5 \mathrm{~Hz}, 1 \mathrm{H}, \mathrm{PhCH}_{2}\right), 3.78\left(\mathrm{~d}, J=13.5 \mathrm{~Hz}, 1 \mathrm{H}, \mathrm{PhCH}_{2}\right)$, $3.78(\mathrm{~s}, 3 \mathrm{H}, \mathrm{Me}), 3.70-3.45\left(\mathrm{~m}, 1 \mathrm{H}, \mathrm{ArCH}_{2}\right), 3.21-3.12\left(\mathrm{~m}, 1 \mathrm{H}, \mathrm{NCH}_{2}\right), 3.07$ (dd, $J=11.9,7.4$ $\mathrm{Hz}, 1 \mathrm{H}, \mathrm{NCH}_{2}$ ), 2.94 (dd, $J=14.3,9.8 \mathrm{~Hz}, 1 \mathrm{H}, \mathrm{ArCH}_{2}$ ).

${ }^{13}$ C NMR $\left(101 \mathrm{MHz}, \mathrm{CDCl}_{3}\right) \delta 188.0,155.7,149.8,142.5,138.1,137.0,135.4,132.3,129.2$, $128.7,128.7,128.5,128.0,127.3,124.1(\mathrm{~d}, J=284.5 \mathrm{~Hz}), 77.1$ (q overlapping with chloroform signal), 59.8, 58.0, 56.8, 53.5, 35.1.

IR $v_{\max } 3066(\mathrm{w}), 2960$ (w), 2903 (w), 1714 (m), 1634 (m), 1448 (s), 1365 (m), 1288 (s), 1174 (m), 1143 (s), 909 (s).

HRMS (ESI) calcd for $\mathrm{C}_{25} \mathrm{H}_{24} \mathrm{~F}_{3} \mathrm{~N}_{2} \mathrm{O}_{3} \mathrm{~S}^{+}[\mathrm{M}+\mathrm{H}]^{+} 489.1454$; found 489.1457 . 


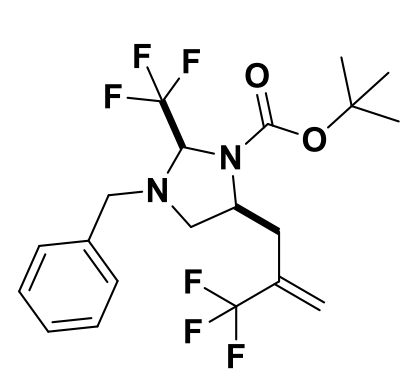

Following General Procedure $\mathbf{D}$, the title compound was prepared from $\mathrm{N}$-benzylprop-2-en-1-amine (1) (44.2 $\mathrm{mg}, 0.300 \mathrm{mmol}), 1-(($ tertbutoxycarbonyl)amino)-2,2,2-trifluoroethyl acetate (2a) $(85 \mathrm{mg}, 0.330$ mmol, 1.1 equiv) and 2-bromo-3,3,3-trifluoroprop-1-ene (79 mg, 0.45 mmol, 1.5 eq) at $70{ }^{\circ} \mathrm{C}$. The crude oil (>20:1 dr determined by integration in the crude ${ }^{1} \mathrm{H}$ NMR) was purified by chromatography on Biotage (SNAP cartridge KP-SIL $25 \mathrm{~g}, 85: 15$ to 40:60 Pentane: $\mathrm{CH}_{2} \mathrm{Cl}_{2}$ ) affording the title compound $\mathbf{3 9}(115 \mathrm{mg}, 0.262 \mathrm{mmol}, 87 \%$ yield $)$ as a

yellow oil.

Rf 0.40 (Pentane: $\mathrm{CH}_{2} \mathrm{Cl}_{2}$ 5:7).

${ }^{1} \mathbf{H}$ NMR $\left(400 \mathrm{MHz}, \mathrm{CDCl}_{3}\right) \delta 7.40-7.28(\mathrm{~m}, 5 \mathrm{H}, \mathrm{ArH}), 5.75-5.65\left(\mathrm{~m}, 1 \mathrm{H}, \mathrm{CCH}_{2}\right), 5.42-5.30$ $\left(\mathrm{m}, 1 \mathrm{H}, \mathrm{CCH}_{2}\right), 5.08-4.77\left(\mathrm{~m}, 1 \mathrm{H}, \mathrm{CHCF}_{3}\right), 4.21-4.01(\mathrm{~m}, 1 \mathrm{H}, \mathrm{NCH}), 3.90(\mathrm{~d}, J=13.4 \mathrm{~Hz}$, $\left.1 \mathrm{H}, \mathrm{PhCH}_{2}\right), 3.77\left(\mathrm{~d}, J=13.2 \mathrm{~Hz}, 1 \mathrm{H}, \mathrm{PhCH}_{2}\right), 3.10-2.94\left(\mathrm{~m}, 3 \mathrm{H}, \mathrm{NCH}_{2}\right.$ and $\left.\mathrm{CH}_{2} \mathrm{CCF}_{3}\right), 2.24$ (dd, $J=14.4,9.9 \mathrm{~Hz}, 1 \mathrm{H}, \mathrm{CH}_{2} \mathrm{CCF}_{3}$ ), 1.48 (s, 9H, Boc).

${ }^{13} \mathrm{C}$ NMR $\left(101 \mathrm{MHz}, \mathrm{CDCl}_{3}\right) \delta 154.3,137.4,135.1(\mathrm{q}, J=30.7 \mathrm{~Hz}), 128.8$ (2 signals), 128.0, $124.4(\mathrm{q}, J=284.6 \mathrm{~Hz}), 123.6(\mathrm{q}, J=273.6 \mathrm{~Hz}), 120.9,81.8,77.0$ (q overlapping with chloroform signals), 59.8, 56.5, 55.3, 34.8, 28.9 .

IR $v_{\max } 2979(\mathrm{w}), 1709(\mathrm{~m}), 1454(\mathrm{w}), 1364(\mathrm{~m}), 1288(\mathrm{w}), 1248(\mathrm{w}), 1169(\mathrm{~s}), 1121(\mathrm{~s}), 1072$ (w), $876(\mathrm{w})$.

HRMS (ESI) calcd for $\mathrm{C}_{20} \mathrm{H}_{24} \mathrm{~F}_{6} \mathrm{~N}_{2} \mathrm{NaO}_{2}{ }^{+}[\mathrm{M}+\mathrm{Na}]^{+}$461.1634; found 461.1648. 


\title{
8. Products transformations.
}

\author{
Tert-butyl \\ carboxylate (14) \\ 2-(trifluoromethyl)-5-(3-(triisopropylsilyl)prop-2-yn-1-yl)imidazolidine-1-
}

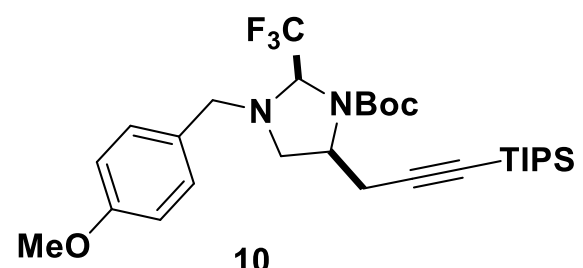

10

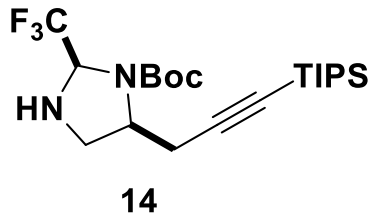

14

Following a slightly modified procedure, ${ }^{26}$ a solution of tert-butyl 3-(4-methoxybenzyl)-2(trifluoromethyl)-5-(3-(triisopropylsilyl)prop-2-yn-1-yl)imidazolidine-1-carboxylate (10) (111 $\mathrm{mg}, 0.200 \mathrm{mmol})$ in $\mathrm{CH}_{2} \mathrm{Cl}_{2}(0.35 \mathrm{~mL})$ was slowly added to a solution of DDQ (54.5 mg, 0.240 mmol, $1.2 \mathrm{eq})$ in $\mathrm{CH}_{2} \mathrm{Cl}_{2}(1 \mathrm{~mL})$ and water $(0.080 \mathrm{~mL})$ at $0{ }^{\circ} \mathrm{C}$. The mixture was stirred at $\mathrm{rt}$ for $10 \mathrm{~h}$ and then poured into ice cold water $(5 \mathrm{~mL})$ and extracted with $\mathrm{CH}_{2} \mathrm{Cl}_{2}(2 \times 10 \mathrm{~mL})$. The combined organic layers were dried over $\mathrm{MgSO}_{4}$, filtered and concentrated under reduced pressure. The crude residue was purified by column chromatography on Biotage (SNAP cartridge KP-SIL $10 \mathrm{~g}, 92: 8$ to 75:25 Pentane:Et $2 \mathrm{O})$ to give the title compound $14(82 \mathrm{mg}, 0.19$ mmol, 94 $\%$ yield) as a colorless oil.

\section{1-(4-Methoxybenzyl)-2-(trifluoromethyl)-4-(3-(triisopropylsilyl)prop-2-yn-1-} yl)imidazolidine (40)

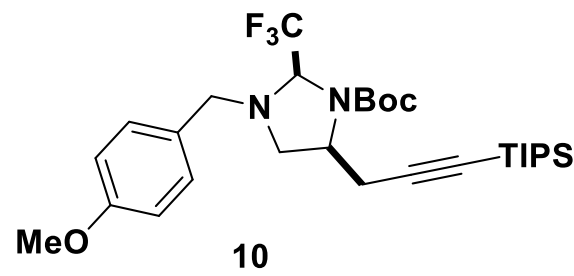

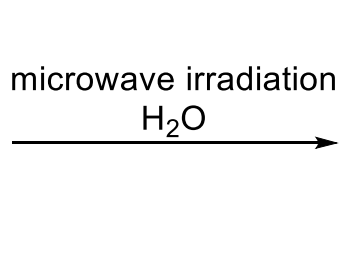

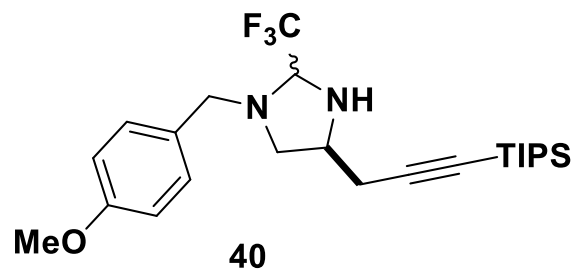

40

A solution of tert-butyl 3-(4-methoxybenzyl)-2-(trifluoromethyl)-5-(3-(triisopropylsilyl)prop-2yn-1-yl)imidazolidine-1-carboxylate (10) $(111 \mathrm{mg}, 0.200 \mathrm{mmol})$ in water:ethanol $(1: 1,3 \mathrm{~mL})$ was heated under microwave irradiation at $160{ }^{\circ} \mathrm{C}$ for $15 \mathrm{~min}$. The volatiles were removed under reduced pressure and the residue to afford the title compound $\mathbf{4 0}$ as a pale yellow oil $(88.2 \mathrm{mg}$, $0.194 \mathrm{mmol}, 97 \%$ yield, 95\% purity, 1:1 dr by integration of the benzylic peaks in the ${ }^{1} \mathrm{H}$ NMR).

Rf 0.10 (EtOAc: $E_{3} \mathrm{~N}$ 99:1).

${ }^{1} \mathbf{H}$ NMR (400 MHz, Chloroform- $d$ ) 1:1 mixture of diastereoisomers A and B $\delta 7.26-7.19(\mathrm{~m}$, $4 \mathrm{H}, \mathrm{ArH} \mathrm{A}$ and B), $6.89-6.82\left(\mathrm{~m}, 4 \mathrm{H}, \mathrm{ArH} \mathrm{A}\right.$ and B), $4.18-4.08\left(\mathrm{~m}, 3 \mathrm{H}, \mathrm{ArCH}_{2} \mathrm{~B}\right.$ and $\mathrm{CHCF}_{3}$ $\mathrm{A}$ and B), $3.99\left(\mathrm{~d}, J=13.0 \mathrm{~Hz}, 1 \mathrm{H}, \mathrm{ArCH}_{2} \mathrm{~A}\right), 3.80(\mathrm{~s}, 6 \mathrm{H}, \mathrm{OMe} \mathrm{A}$ and B), $3.63(\mathrm{~d}, J=13.0 \mathrm{~Hz}$, $\left.1 \mathrm{H}, \mathrm{ArCH}_{2} \mathrm{~A}\right), 3.58\left(\mathrm{~d}, J=12.7 \mathrm{~Hz}, 1 \mathrm{H}, \mathrm{ArCH}_{2} \mathrm{~B}\right), 3.54-3.45(\mathrm{~m}, 2 \mathrm{H}, \mathrm{NCH} \mathrm{A}$ and $\mathrm{B}), 3.00$ (dd, $\left.J=8.4,5.2 \mathrm{~Hz}, 1 \mathrm{H}, \mathrm{NCH}_{2} \mathrm{~B}\right), 2.94\left(\mathrm{dd}, J=10.4,5.6 \mathrm{~Hz}, 1 \mathrm{H}, \mathrm{NCH}_{2} \mathrm{~A}\right), 2.83(\mathrm{dd}, J=10.4$,

${ }^{26}$ Lehmann, L.; Friebe M.; Brumby T.; Suelzle D.; Platzek J. (Schering Aktiengesellschaft) WO2004/87656 A1, 2004. 
$\left.6.3 \mathrm{~Hz}, 1 \mathrm{H}, \mathrm{NCH}_{2} \mathrm{~A}\right), 2.63\left(\mathrm{dd}, J=17.3,5.4 \mathrm{~Hz}, 2 \mathrm{H}, \mathrm{CH}_{2} \mathrm{CC} \mathrm{B}\right.$ and $\left.\mathrm{NH}\right), 2.52-2.39(\mathrm{~m}, 4 \mathrm{H}$, $\left.\mathrm{NCH}_{2} \mathrm{~B} \mathrm{CH}_{2} \mathrm{CC} \mathrm{B}, \mathrm{CH}_{2} \mathrm{CC} \mathrm{A}\right), 1.09-1.04$ (m, 21H, TIPS B), $1.04-0.99$ (m, 21H, TIPS A).

${ }^{13} \mathbf{C}$ NMR $\left(101 \mathrm{MHz}, \mathrm{CDCl}_{3}\right)$ 1:1 mixture of diastereoisomers $\delta$ 159.1, 159.0, 130.5, 130.3, 130.0, 129.9, 125.5 (q, $J=282.2 \mathrm{~Hz}), 125.1$ (q, $J=282.0 \mathrm{~Hz}), 113.9$ (2C), 105.7, 103.1, 84.7, 82.3, 77.7 (q overlapping with chloroform signal, $J=31.2 \mathrm{~Hz}$ ), 77.6 (q overlapping with chloroform signal, $J=31.4 \mathrm{~Hz}$ ), 58.9, 58.4, 57.5, 57.0, 55.6, 55.4 (2C), 55.3, 26.2, 22.6, 18.8, 18.7, 11.3, 11.3.

IR $v_{\max } 2943(\mathrm{~s}), 2866(\mathrm{~m}), 2173(\mathrm{w}), 1614(\mathrm{w}), 1514(\mathrm{~m}), 1464(\mathrm{~m}), 1382(\mathrm{w}), 1289(\mathrm{~m}), 1249$ (s), $1156(\mathrm{~s}), 1035(\mathrm{~m}), 919(\mathrm{w}), 884(\mathrm{~m}), 832(\mathrm{w})$.

HRMS (ESI) calcd for $\mathrm{C}_{24} \mathrm{H}_{38} \mathrm{~F}_{3} \mathrm{~N}_{2} \mathrm{OSi}^{+}[\mathrm{M}+\mathrm{H}]^{+}$455.2700; found 455.2709.

\section{Tert-butyl 3-(4-methoxybenzyl)-5-(prop-2-yn-1-yl)-2-(trifluoromethyl)imidazolidine-1- carboxylate (41)}
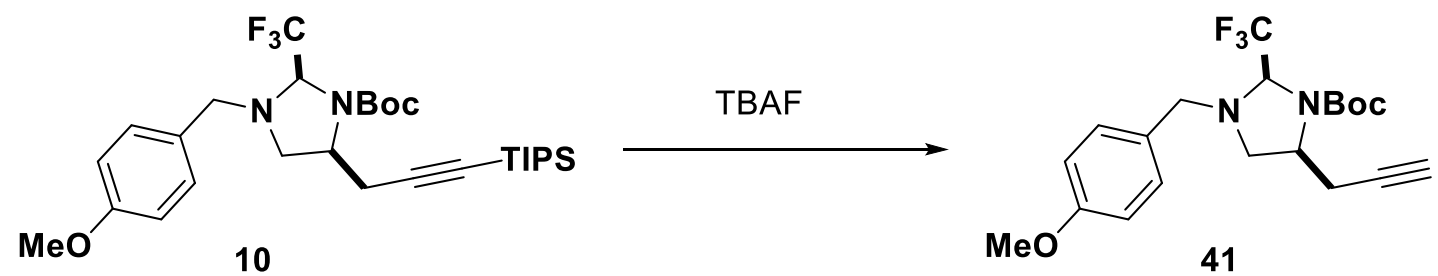

To a solution of tert-butyl 3-(4-methoxybenzyl)-2-(trifluoromethyl)-5-(3-(triisopropylsilyl)prop2-yn-1-yl)imidazolidine-1-carboxylate (10) $(222 \mathrm{mg}, 0.400 \mathrm{mmol})$ in THF (Volume: $5.5 \mathrm{~mL})$ at 0 ${ }^{\circ} \mathrm{C}$ was added dropwise a $1 \mathrm{~N}$ solution of TBAF $(1.08 \mathrm{~mL}, 1.08 \mathrm{mmol}, 2$ equiv) in THF. The reaction mixture was stirred for $45 \mathrm{~min}$ at $\mathrm{rt}$ and then quenched by addition of a solution of sat. $\mathrm{NH}_{4} \mathrm{Cl}$ and diluted with $\mathrm{Et}_{2} \mathrm{O}(10 \mathrm{~mL})$. The organic layer was washed with brine $(2 \times 2 \mathrm{~mL})$, dried over $\mathrm{MgSO}_{4}$, filtered and concentrated under reduced pressure. The crude residue was purified by column chromatography on Biotage (SNAP cartridge KP-SIL $10 \mathrm{~g}$, 93:7 to 85:15 Pentane:EtOAc) to give the title compound 41 (156 mg, $0.392 \mathrm{mmol}, 98 \%$ yield) as a pale yellow oil.

Rf 0.75 (Pentane: $\mathrm{Et}_{2} \mathrm{O} 2: 1$ ).

${ }^{1} \mathbf{H}$ NMR $\left(400 \mathrm{MHz}, \mathrm{CDCl}_{3}\right) \delta 7.26-7.20(\mathrm{~m}, 2 \mathrm{H}, \mathrm{ArH}), 6.89-6.84(\mathrm{~m}, 2 \mathrm{H}, \mathrm{ArH}), 5.06-4.72$ $\left(\mathrm{m}, 1 \mathrm{H}, \mathrm{CHCF}_{3}\right), 4.14-3.86(\mathrm{~m}, 1 \mathrm{H}, \mathrm{CHNBoc}), 3.79$ (s, 3H, Me), 3.74 (s, 2H, $\mathrm{ArCH}$ ), $3.30-$ $3.14\left(\mathrm{~m}, 2 \mathrm{H}, \mathrm{CH}_{2} \mathrm{~N}\right), 3.00-2.75\left(\mathrm{~m}, 1 \mathrm{H}, \mathrm{CH}_{2} \mathrm{CC}\right), 2.24(\mathrm{ddd}, J=16.3,10.1,2.7 \mathrm{~Hz}, 1 \mathrm{H}$, $\left.\mathrm{CH}_{2} \mathrm{CC}\right), 1.93(\mathrm{t}, J=2.7 \mathrm{~Hz}, 1 \mathrm{H}, \mathrm{CCH}), 1.46$ (s, 9H, Boc).

${ }^{13}$ C NMR $\left(101 \mathrm{MHz}, \mathrm{CDCl}_{3}\right) \delta 159.3,154.1,130.1,129.3,124.2$ (q, J = 284.2 Hz), 114.0, 81.6, $80.3,77.1(\mathrm{q}, J=33.3 \mathrm{~Hz}), 70.2,59.3,56.7,55.5,55.3,28.3,23.6$.

IR $v_{\max } 3305(\mathrm{w}), 3006(\mathrm{w}), 2937(\mathrm{w}), 2838(\mathrm{w}), 2121(\mathrm{w}), 1707(\mathrm{~s}), 1613(\mathrm{w}), 1514(\mathrm{~m}), 1463$ (w), 1366 (s), 1287 (m), 1249 (s), 1155 (s), $1031(\mathrm{w}), 872$ (m).

HRMS (ESI) calcd for $\mathrm{C}_{20} \mathrm{H}_{26} \mathrm{~F}_{3} \mathrm{~N}_{2} \mathrm{O}_{3}{ }^{+}[\mathrm{M}+\mathrm{H}]^{+}$399.1890; found 399.1889. 

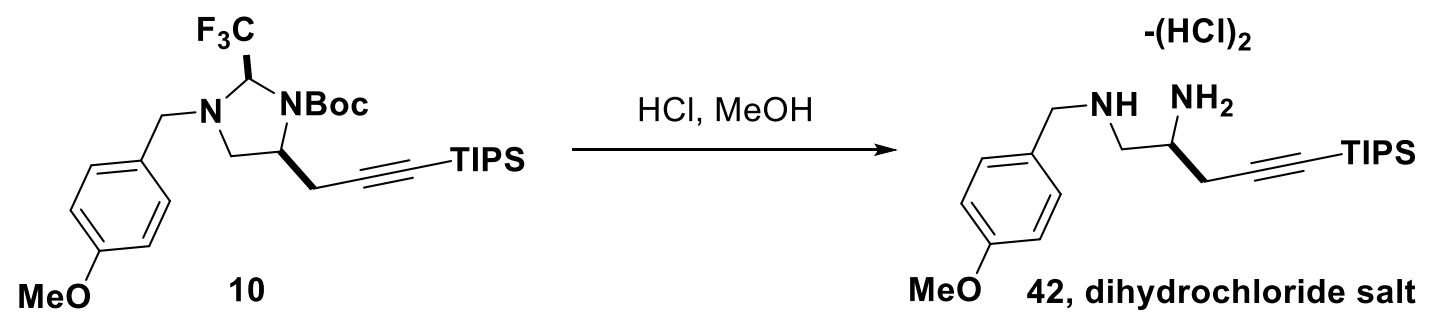

A solution of tert-butyl 3-(4-methoxybenzyl)-2-(trifluoromethyl)-5-(3-(triisopropylsilyl)prop-2yn-1-yl)imidazolidine-1-carboxylate (10) $(111 \mathrm{mg}, 0.200 \mathrm{mmol})$ in $\mathrm{MeOH}(1 \mathrm{~mL})$ at $-40{ }^{\circ} \mathrm{C}$ was treated with a $4 \mathrm{~N} \mathrm{HCl}$ solution in $\mathrm{CPME}(0.125 \mathrm{~mL}, 0.500 \mathrm{mmol}, 2.5$ equiv). The reaction mixture was allowed to slowly warm up to rt over $5 \mathrm{~h}$. Then nitrogen was bubbled in the reaction mixture and the volatiles were removed under reduced pressure. The residue was further dried by co-evaporation with toluene to afford a solid. The solid was triturated with an ice cold mixture of pentane and acetonitrile $(4: 1,3 \times 0.1 \mathrm{~mL})$ to afford the title compound $\mathbf{4 2}(80 \mathrm{mg}, 0.18 \mathrm{mmol}, 89 \%$ yield) as a beige solid.

m.p.: $185-186{ }^{\circ} \mathrm{C}$.

${ }^{1}$ H NMR (400 MHz, Methanol- $\left.d_{4}\right) \delta 7.54-7.48(\mathrm{~m}, 2 \mathrm{H}, \mathrm{ArH}), 7.04-6.97(\mathrm{~m}, 2 \mathrm{H}, \mathrm{ArH}), 4.30$ $\left(\mathrm{d}, J=13.0 \mathrm{~Hz}, 1 \mathrm{H}, \mathrm{ArCH}_{2}\right), 4.24\left(\mathrm{~d}, J=13.0 \mathrm{~Hz}, 1 \mathrm{H}, \mathrm{ArCH}_{2}\right), 3.87-3.78(\mathrm{~m}, 1 \mathrm{H}, \mathrm{NCH}), 3.82$ (s, 3H, OMe), 3.48 (dd, $\left.J=13.8,4.4 \mathrm{~Hz}, 1 \mathrm{H}, \mathrm{NCH}_{2}\right), 3.41\left(\mathrm{dd}, J=13.8,7.5 \mathrm{~Hz}, 1 \mathrm{H}, \mathrm{NCH}_{2}\right), 2.93$ (dd, $\left.J=17.5,5.5 \mathrm{~Hz}, 1 \mathrm{H}, \mathrm{CH}_{2} \mathrm{CC}\right), 2.86\left(\mathrm{dd}, J=17.5,7.3 \mathrm{~Hz}, 1 \mathrm{H}, \mathrm{CH}_{2} \mathrm{CC}\right), 1.16-0.99(\mathrm{~m}, 21 \mathrm{H}$, TIPS).

${ }^{13}$ C NMR (101 MHz, MeOD) $\delta$ 162.4, 132.9, 123.2, 115.7, 101.0, 87.8, 55.8, 52.8, 48.9 (overlapping with methanol signal), 48.8 (overlapping with methanol signal), 23.4, 19.0, 12.4.

IR $v_{\max } 3408(\mathrm{~m}), 3340(\mathrm{~m}), 3282(\mathrm{~m}), 2942(\mathrm{w}), 2864(\mathrm{w}), 2179(\mathrm{w}), 1614(\mathrm{~m}), 1517(\mathrm{~s}), 1463$ (m), 1307 (w), 1254 (s), 1182 (m), 1078 (s), 1037 (s), 884 (m), 836 (m).

HRMS (ESI) calcd for $\mathrm{C}_{21} \mathrm{H}_{39} \mathrm{~N}_{2} \mathrm{OSi}[\mathrm{M}+\mathrm{H}]^{+}$375.2826; found 375.2816.

\section{1-(Pyrrolidin-2-yl)-4-(triisopropylsilyl)but-3-yn-1-amine bis(2,2,2-trifluoroacetate) (43)}

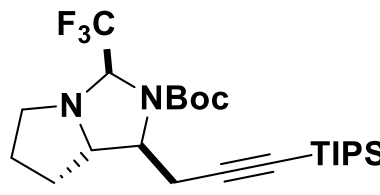

20

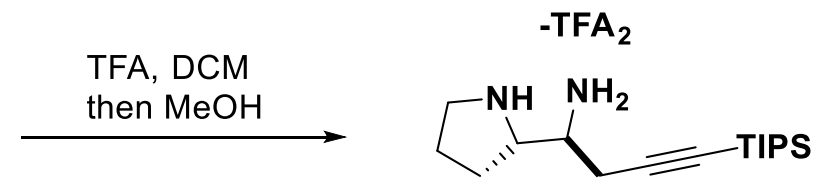

43, bis TFA salt

A solution of tert-butyl 3-(trifluoromethyl)-1-(3-(triisopropylsilyl)prop-2-yn-1-yl)tetrahydro-1Hpyrrolo[1,2-c]imidazole-2(3H)-carboxylate (20) $(95.0 \mathrm{mg}, 0.200 \mathrm{mmol})$ in DCM $(2.5 \mathrm{~mL})$ was treated with TFA $(0.6 \mathrm{~mL})$ at $0{ }^{\circ} \mathrm{C}$ and stirred at $\mathrm{rt}$ for $3 \mathrm{~h}$ and then dry methanol $(1 \mathrm{~mL})$ was added and the reaction was further stirred $1 \mathrm{~h}$. The volatiles were removed under reduced pressure. The residue was further dried by co-evaporation with toluene to afford the pure title compound 43 (100 mg, $0.191 \mathrm{mmol}, 96 \%$ yield) as a light brown solid.

m.p.: $121-125^{\circ} \mathrm{C}$. 
${ }^{1} \mathbf{H}$ NMR (400 MHz, Acetonitrile-d $\left.d_{3}\right) \delta 7.99(\mathrm{~s}, 5 \mathrm{H}, \mathrm{NH}), 4.01-3.89\left(\mathrm{~m}, 1 \mathrm{H}, \mathrm{CHNH}_{2}\right), 3.83-$ $3.74\left(\mathrm{~m}, 1 \mathrm{H}, \mathrm{CHNH}\right.$ ), $3.36\left(\mathrm{dd}, J=8.7,5.9 \mathrm{~Hz}, 2 \mathrm{H}, \mathrm{CH}_{2} \mathrm{NH}_{2}\right), 2.89(\mathrm{dd}, J=18.3,3.9 \mathrm{~Hz}, 1 \mathrm{H}$, $\mathrm{CH}_{2} \mathrm{CC}$ ), 2.77 (dd, $\mathrm{J}=18.3,4.4 \mathrm{~Hz}, 1 \mathrm{H}, \mathrm{CH}_{2} \mathrm{CC}$ ), $2.35-2.24\left(\mathrm{~m}, 1 \mathrm{H}, \mathrm{CH}_{2} \mathrm{CHNH}_{2}\right), 2.18-2.06$ $\left(\mathrm{m}, 1 \mathrm{H}, \mathrm{CH}_{2} \mathrm{CH}_{2} \mathrm{NH}_{2}\right), 2.03-1.93$ (m, partially overlapped with acetonitrile signal, $1 \mathrm{H}$, $\mathrm{CH}_{2} \mathrm{CH}_{2} \mathrm{NH}_{2}$ ), $1.87-1.73$ (m, 1H, $\mathrm{CH}_{2} \mathrm{CHNH}_{2}$ ), 1.08 (s, 21H, TIPS).

${ }^{13}$ C NMR $\left(101 \mathrm{MHz}, \mathrm{CD}_{3} \mathrm{CN}\right) \delta 162.8(\mathrm{~m}), 117.5(\mathrm{q}, J=292.7 \mathrm{~Hz}), 100.2,87.7,61.9,51.7,47.0$, $29.2,24.5,23.8,18.9,11.9$.

IR $v_{\max } 3518(\mathrm{w}), 2947(\mathrm{w}), 2868(\mathrm{w}), 2178(\mathrm{w}), 1672(\mathrm{~s}), 1437(\mathrm{w}), 1191(\mathrm{~s}), 1138(\mathrm{~s}), 997(\mathrm{w})$, $884(\mathrm{w}), 841(\mathrm{w})$.

HRMS (ESI) calcd for $\mathrm{C}_{17} \mathrm{H}_{35} \mathrm{~N}_{2} \mathrm{Si}[\mathrm{M}+\mathrm{H}]^{+}$295.2564; found 295.2570.

\section{N1-benzyl-3-(3,5-bis(trifluoromethyl)phenyl)-2-methylpropane-1,2-diamine bis(2,2,2- trifluoroacetate) (44)}
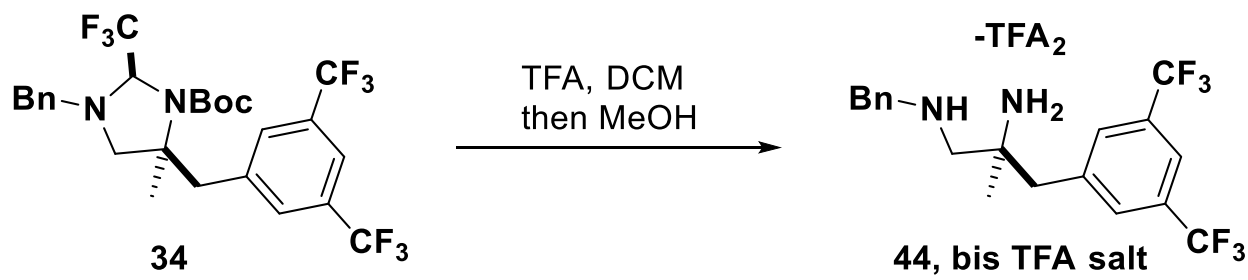

A solution of tert-butyl 3-benzyl-5-(3,5-bis(trifluoromethyl)benzyl)-5-methyl-2(trifluoromethyl)imidazolidine-1-carboxylate (34) $(114 \mathrm{mg}, 0.200 \mathrm{mmol})$ in DCM $(2.5 \mathrm{~mL})$ was treated with TFA $(0.6 \mathrm{~mL})$ at $0{ }^{\circ} \mathrm{C}$ and stirred at $\mathrm{rt}$ for $3 \mathrm{~h}$ and then dry methanol $(1 \mathrm{~mL})$ was added and the reaction was further stirred $1 \mathrm{~h}$. The volatiles were removed under reduced pressure. The residue was further dried by co-evaporation with toluene to afford the pure title compound 44 (122 mg, $0.197 \mathrm{mmol}, 99 \%$ yield) as a sticky yellow oil.

${ }^{1} \mathbf{H}$ NMR (400 MHz, Acetonitrile- $\left.d_{3}\right) \delta 8.85(\mathrm{~s}, 5 \mathrm{H}, \mathrm{NH}), 7.99(\mathrm{~s}, 1 \mathrm{H}, \mathrm{Ar} H), 7.89-7.81(\mathrm{~m}, 2 \mathrm{H}$, $\mathrm{ArH}), 7.55-7.48$ (m, 2H, ArH), $7.45-7.38$ (m, 3H, $\mathrm{ArH}), 4.31-4.19$ (m, 2H, $\left.\mathrm{PhCH}_{2}\right), 3.39$ (d, $\left.J=14.0 \mathrm{~Hz}, 1 \mathrm{H}, \mathrm{NCH}_{2}\right), 3.37\left(\mathrm{~d}, J=14.1 \mathrm{~Hz}, 1 \mathrm{H}, \mathrm{ArCH}_{2}\right), 3.33(\mathrm{~d}, J=14.0 \mathrm{~Hz}, 1 \mathrm{H}, \mathrm{NCH})$, $3.17\left(\mathrm{~d}, J=14.1 \mathrm{~Hz}, 1 \mathrm{H}, \mathrm{ArCH}_{2}\right), 1.44$ (s, 3H, Me).

${ }^{13}$ C NMR (101 MHz, CD $\left.{ }_{3} \mathrm{CN}\right) \delta 162.5(\mathrm{q}, J=35.4 \mathrm{~Hz}), 137.0,132.5(\mathrm{q}, J=33.3 \mathrm{~Hz}), 132.4(\mathrm{~m})$, $131.3,131.2,130.5,129.9,124.4(\mathrm{q}, J=272.0 \mathrm{~Hz}), 122.9(\mathrm{~m}), 56.2,53.5,53.2,42.9,22.0$.

IR $v_{\max } 3533(\mathrm{w}), 3043(\mathrm{w}), 2838(\mathrm{w}), 2584(\mathrm{w}), 1671(\mathrm{~m}), 1463(\mathrm{w}), 1437(\mathrm{w}), 1381(\mathrm{w}), 1281$ (m), 1176 (s), 1130 (s), $1030(\mathrm{w}), 903$ (w), $840(\mathrm{w})$.

HRMS (ESI) calcd for $\mathrm{C}_{19} \mathrm{H}_{21} \mathrm{~F}_{6} \mathrm{~N}_{2}[\mathrm{M}+\mathrm{H}]^{+}$391.1603; found 391.1606. 
9. Spectra of new compounds $\left({ }^{1} \mathrm{HNMR},{ }^{13} \mathrm{CNMR}\right.$, IR)

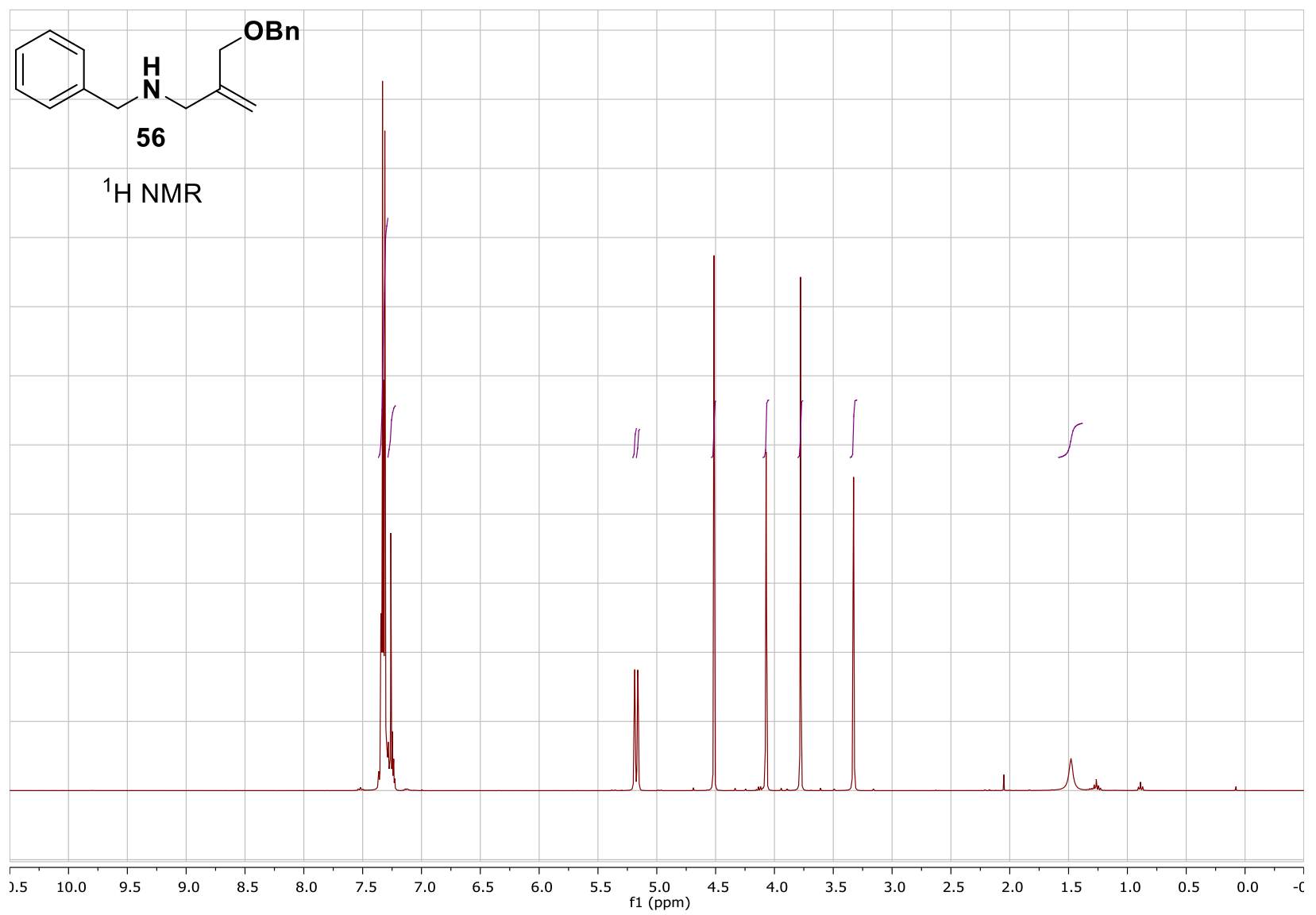



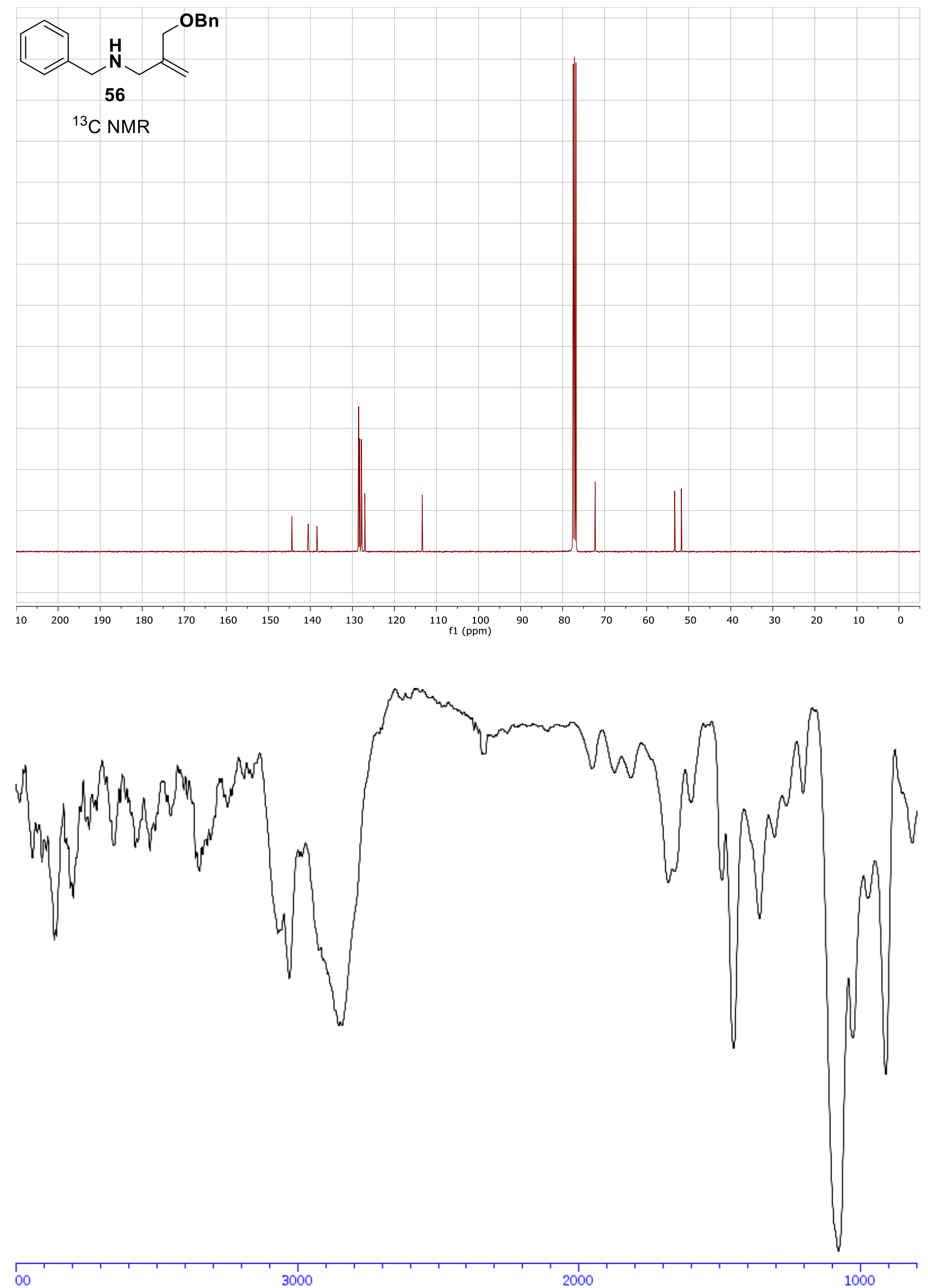

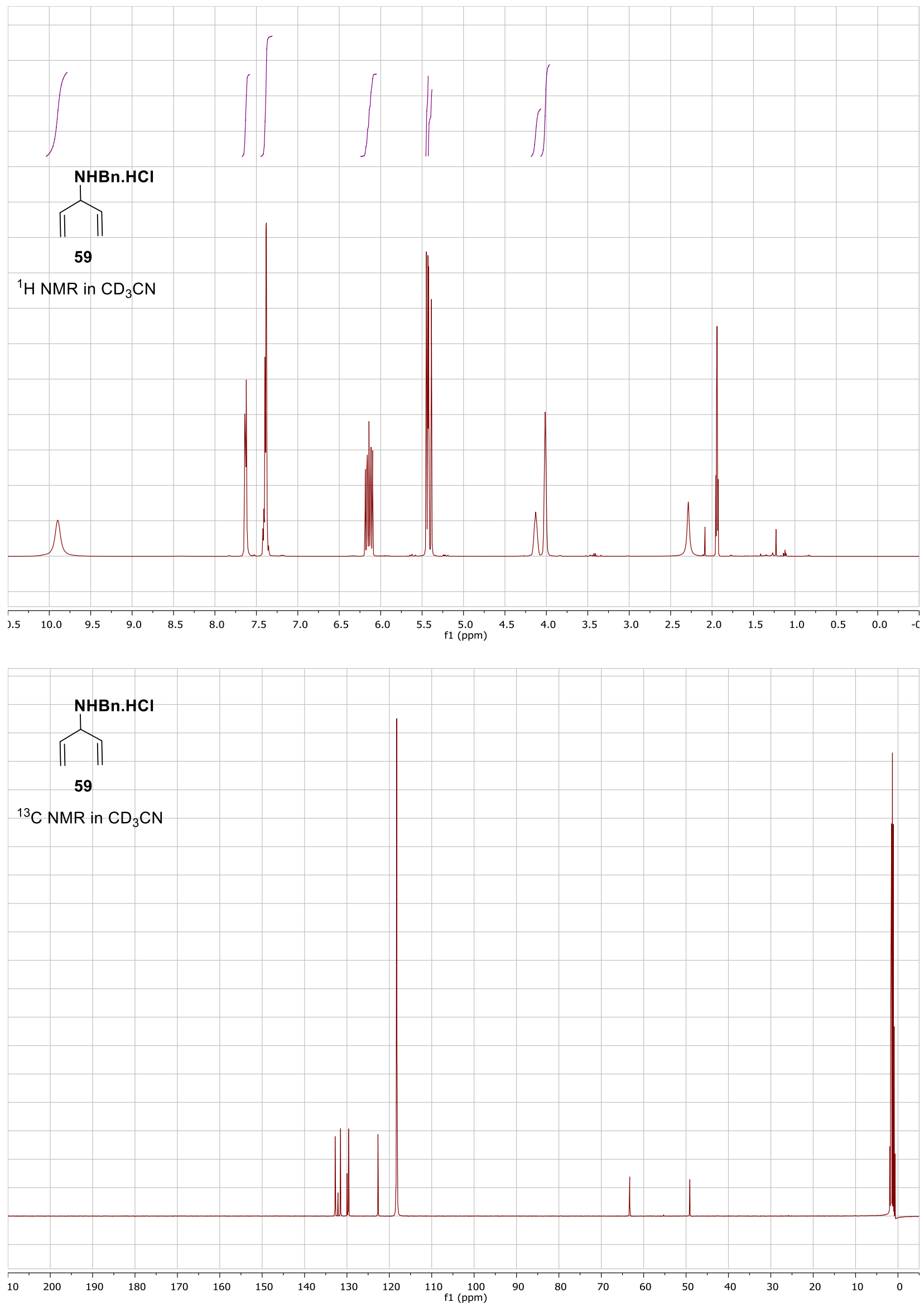


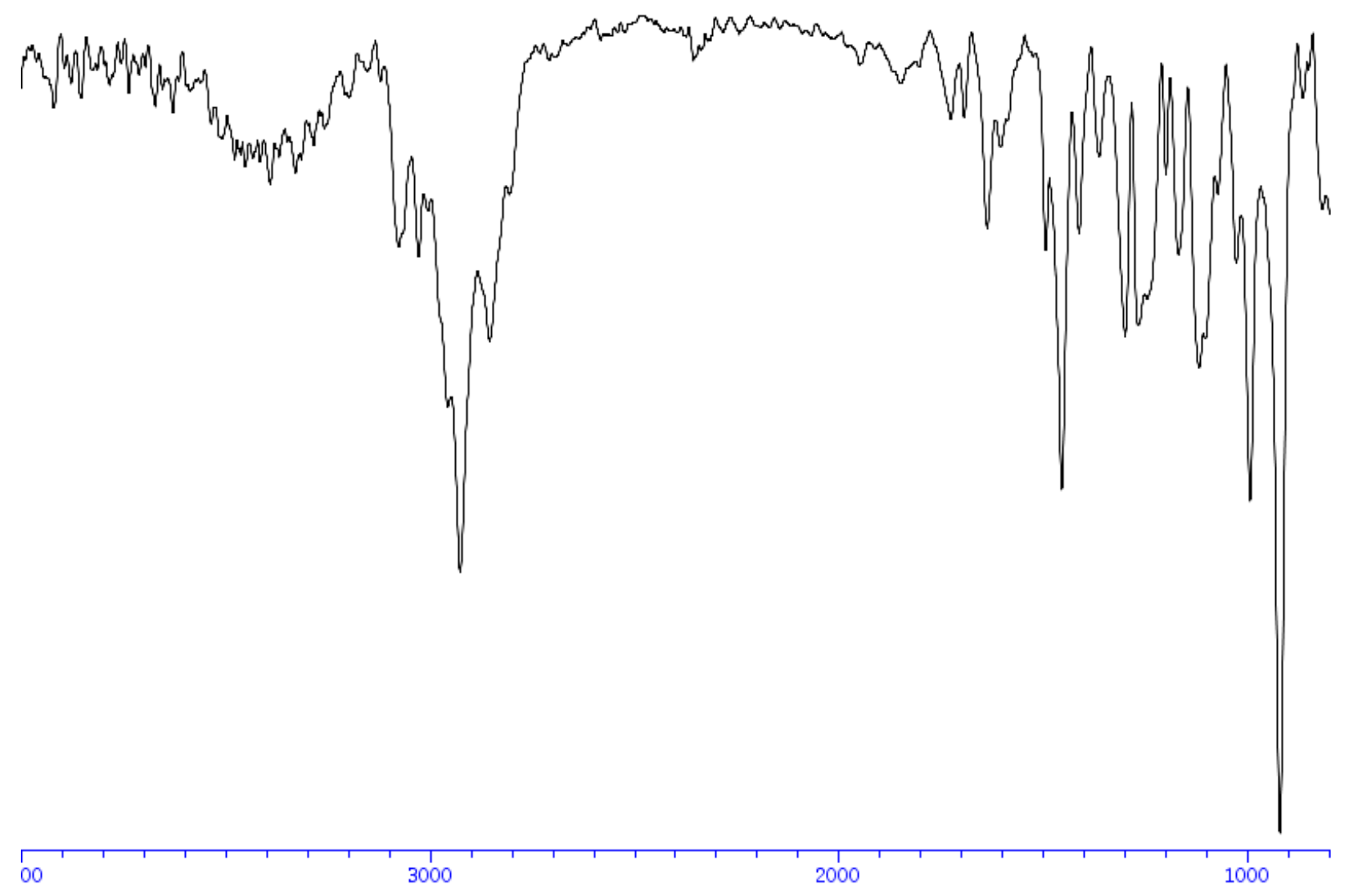




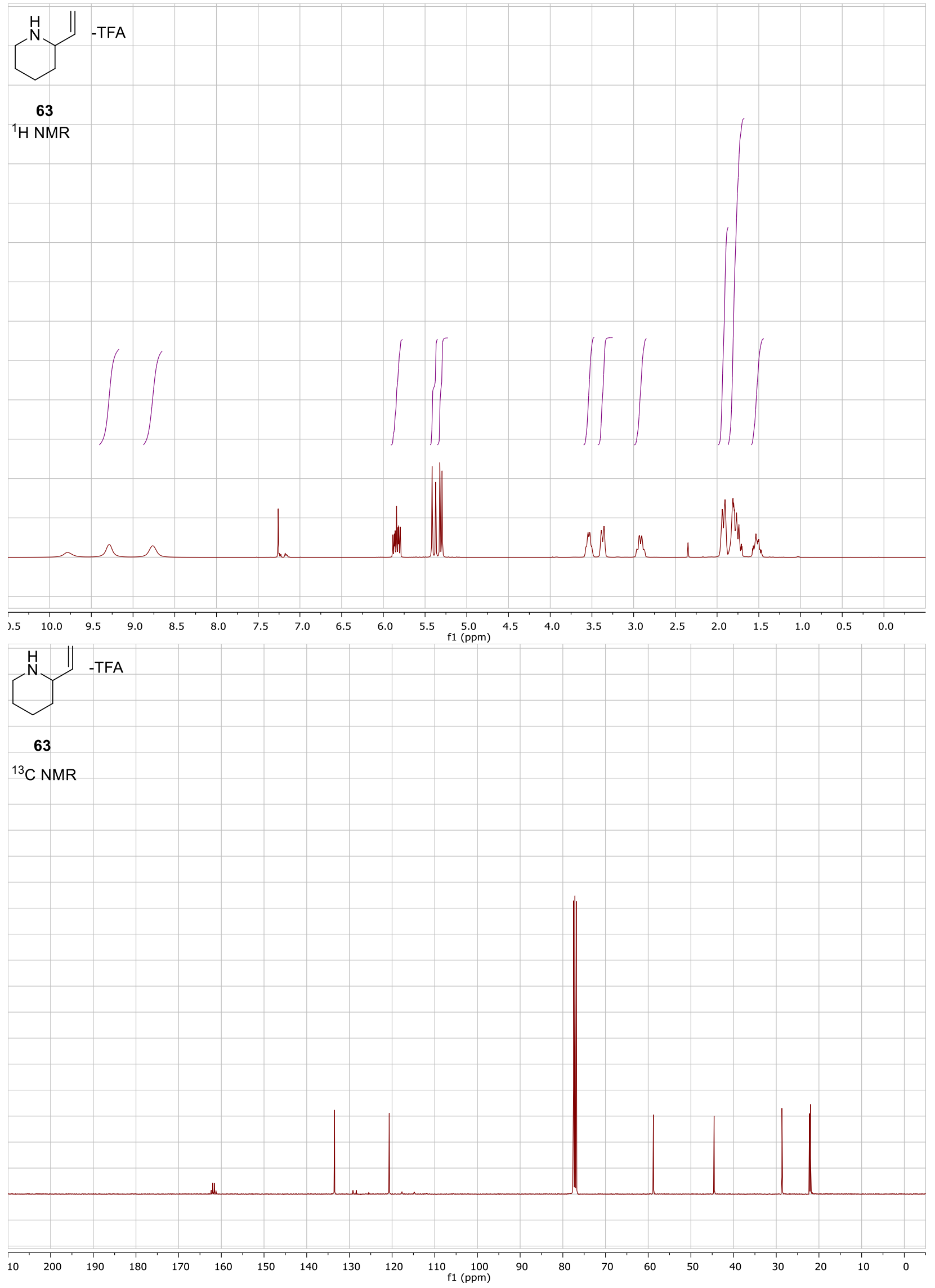




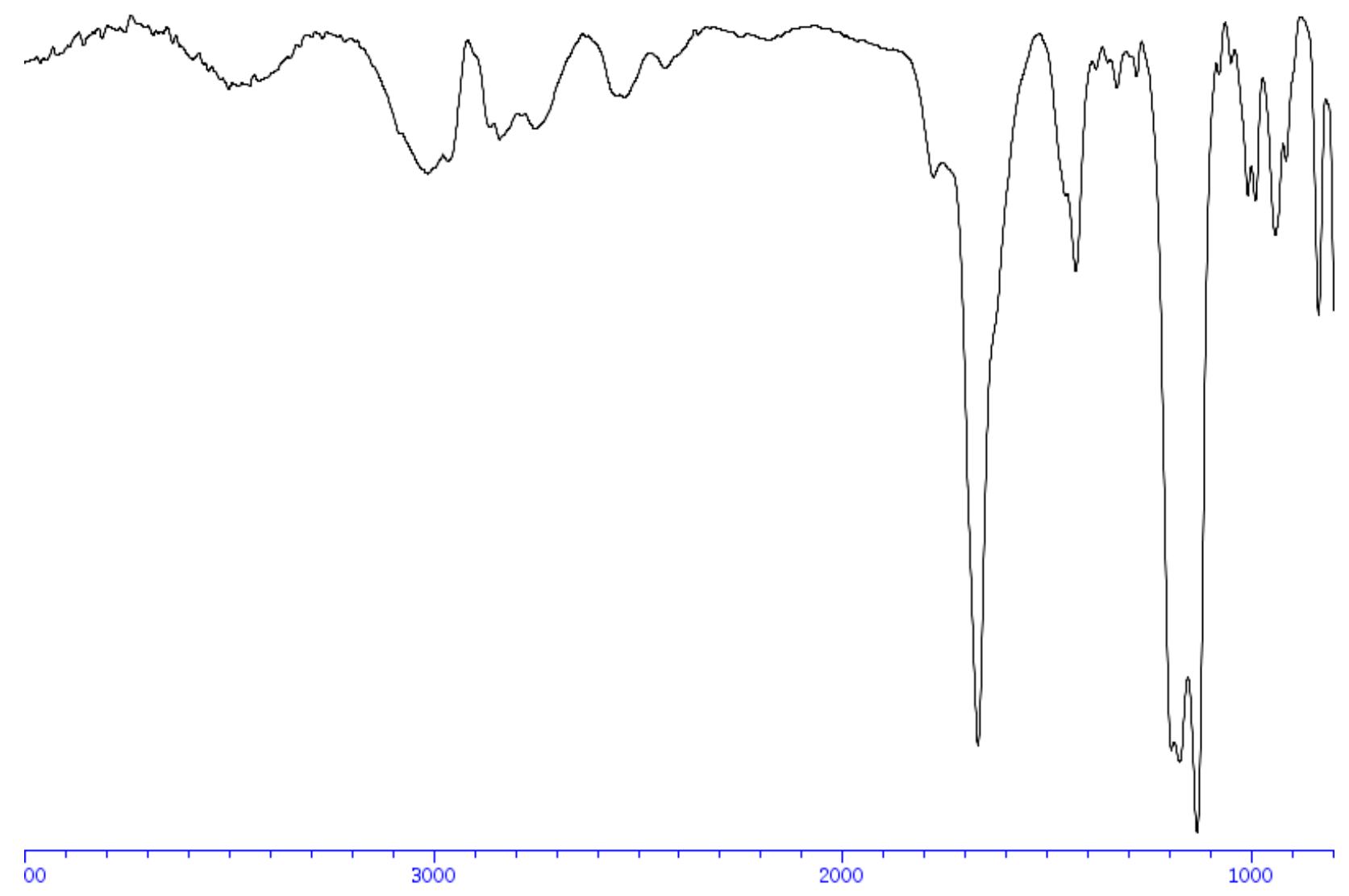




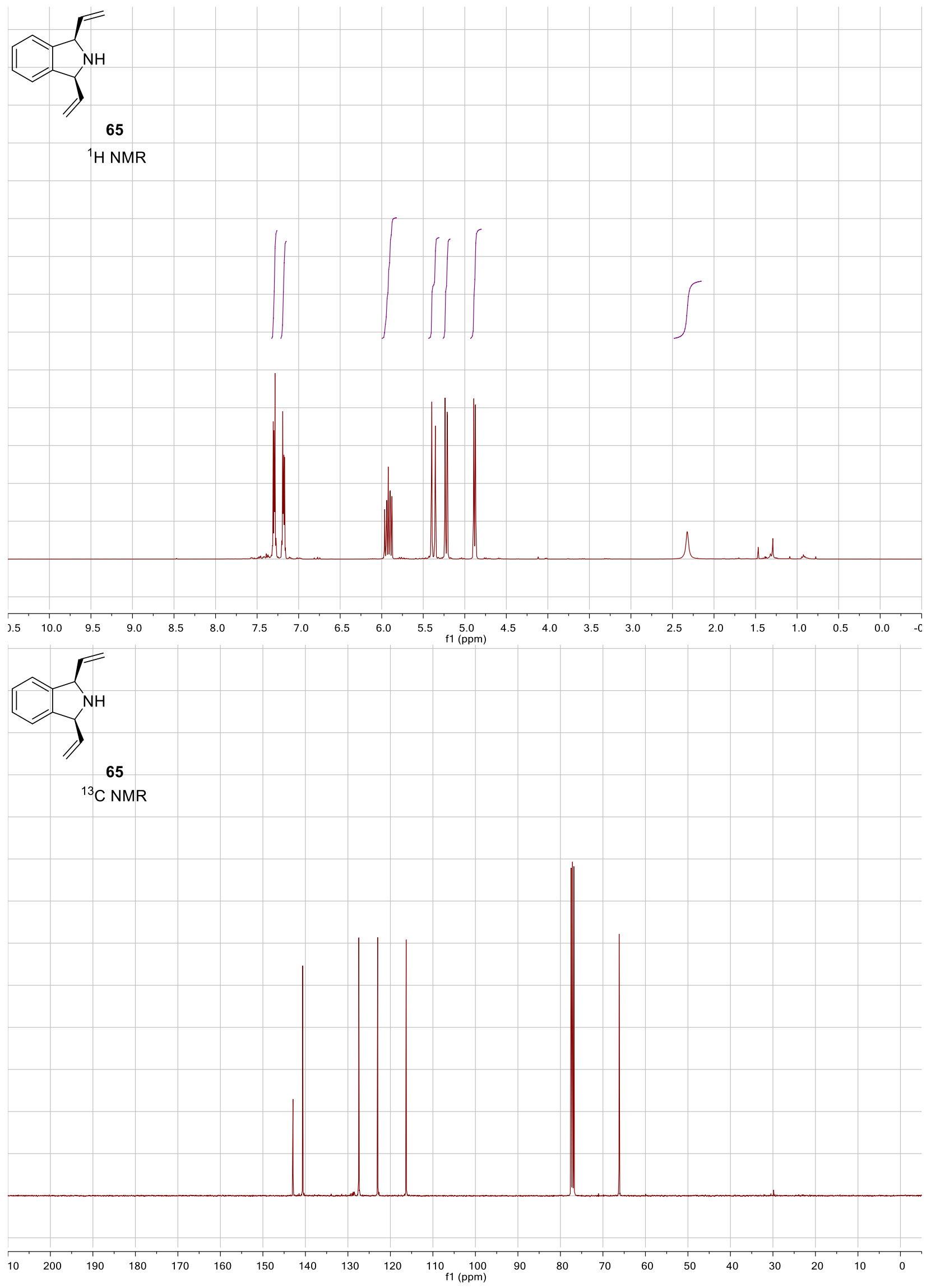




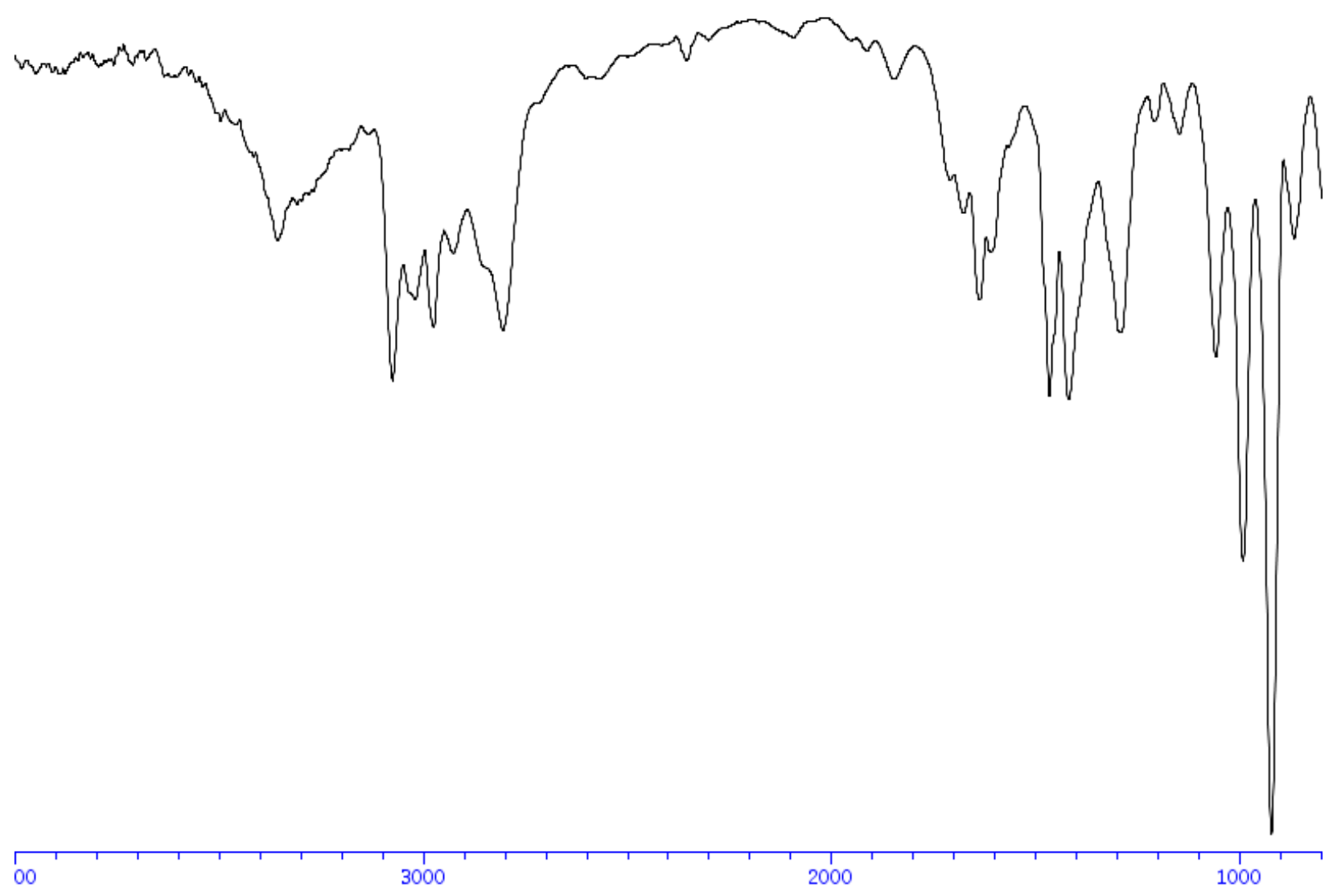




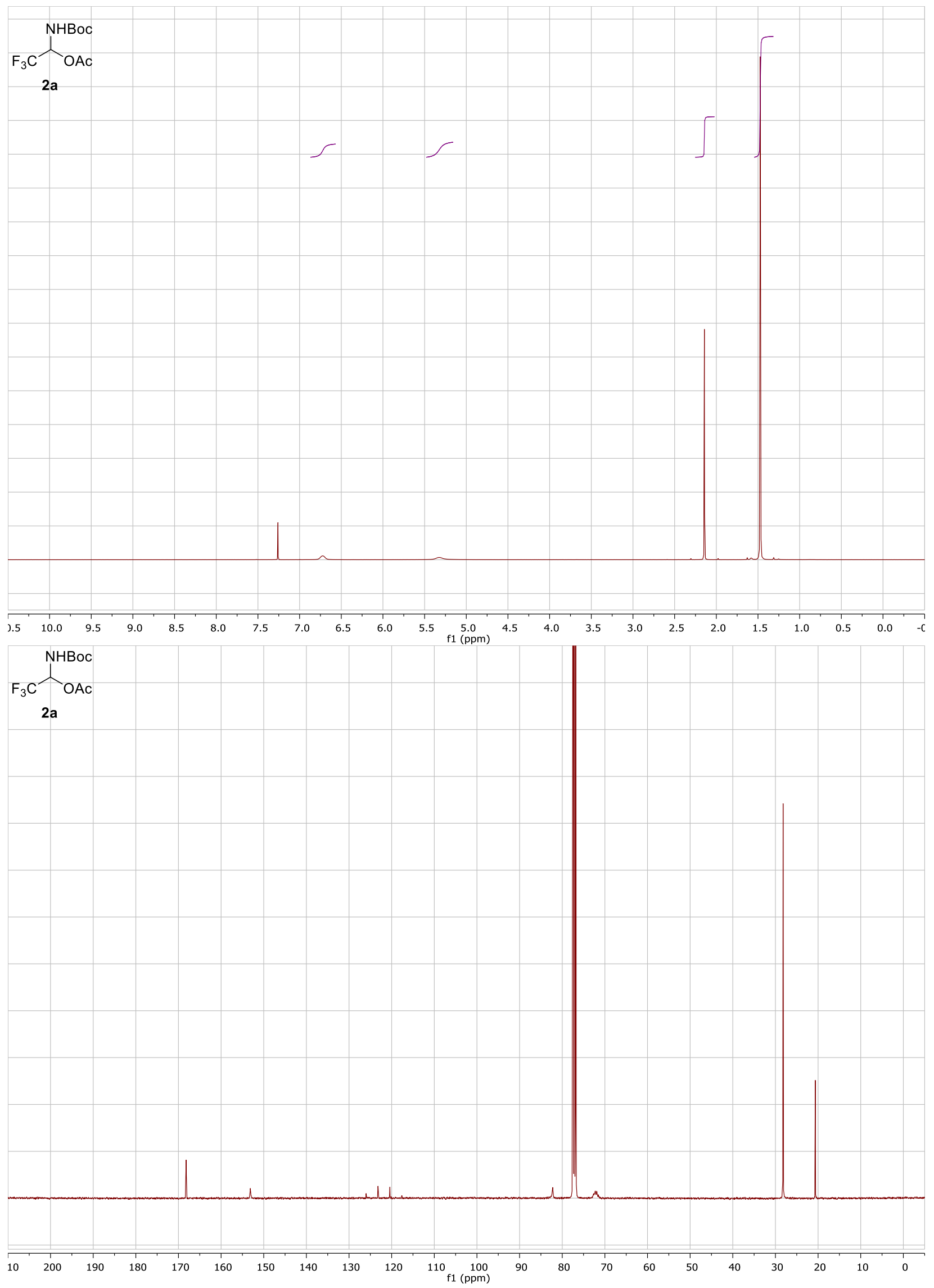




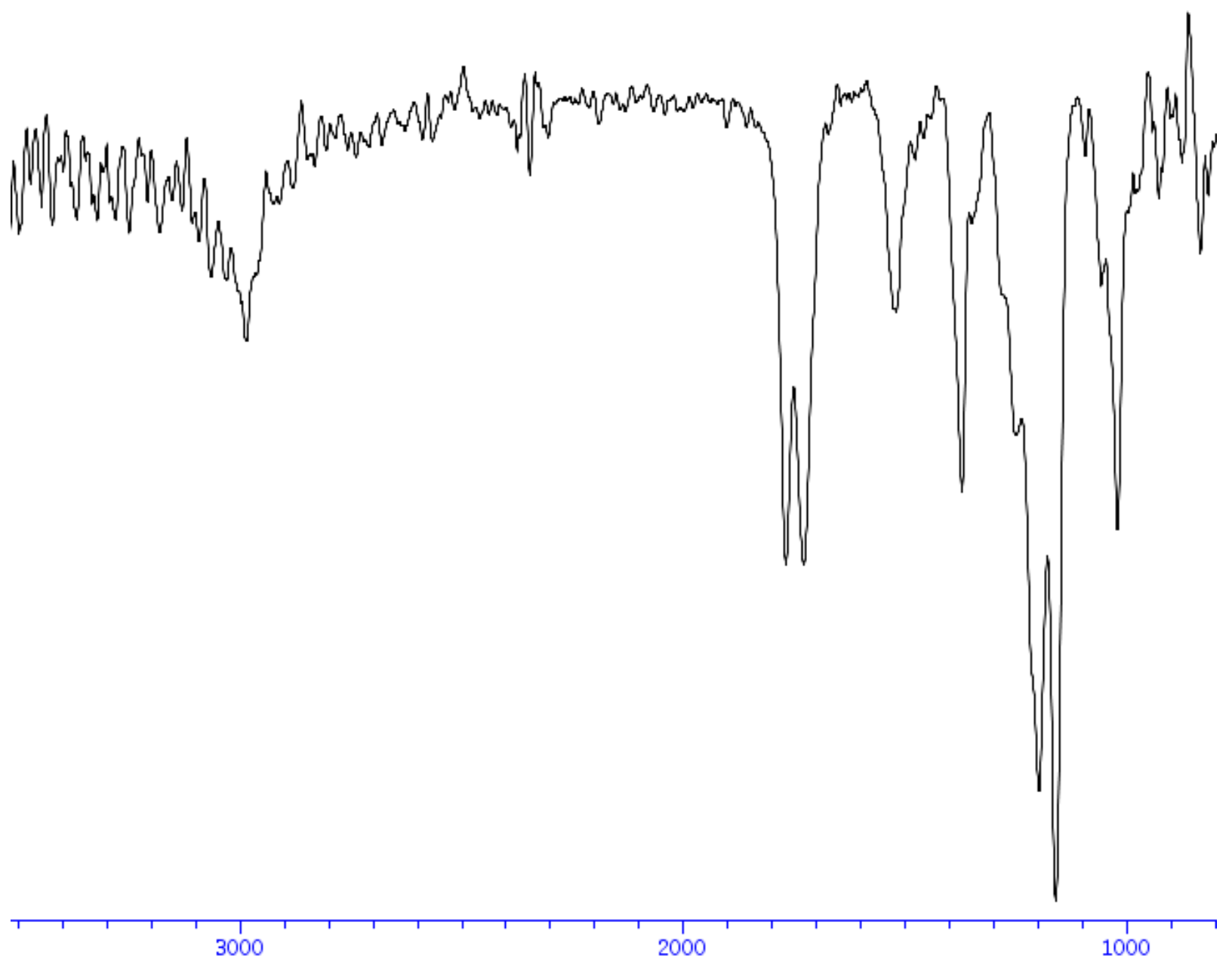




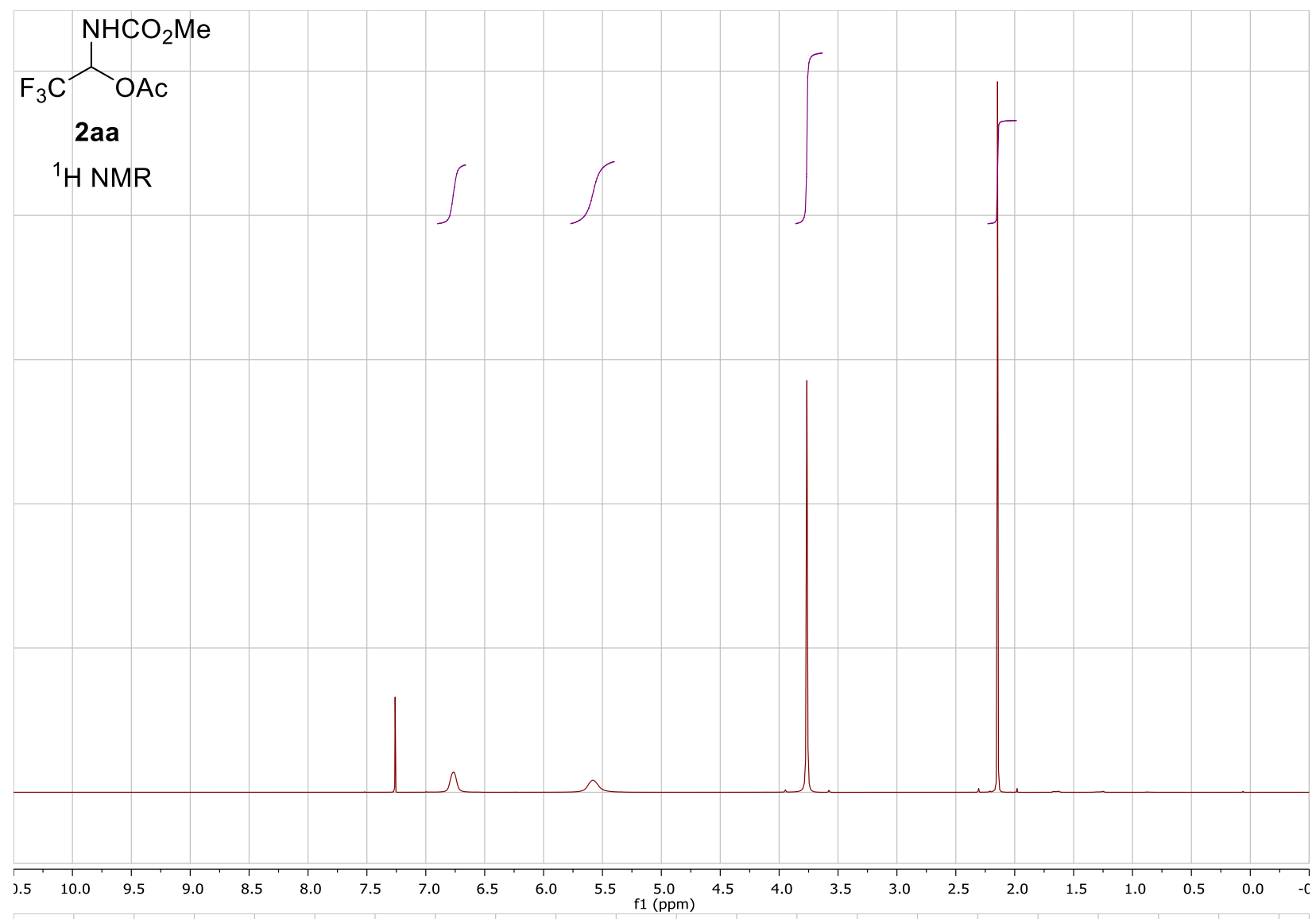

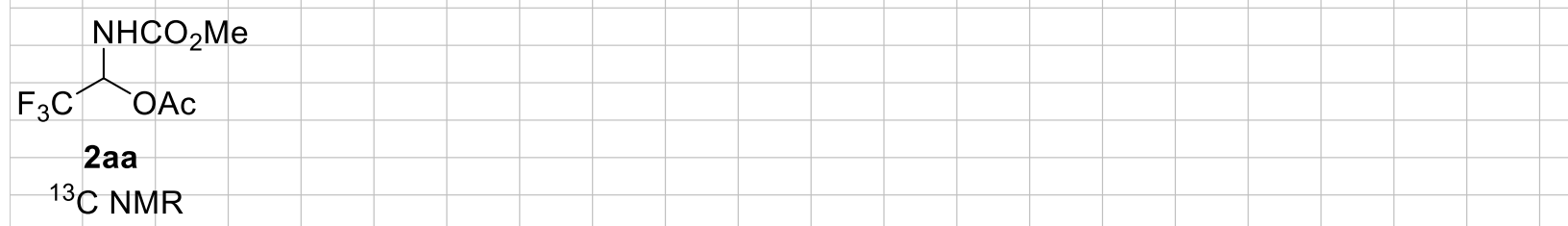

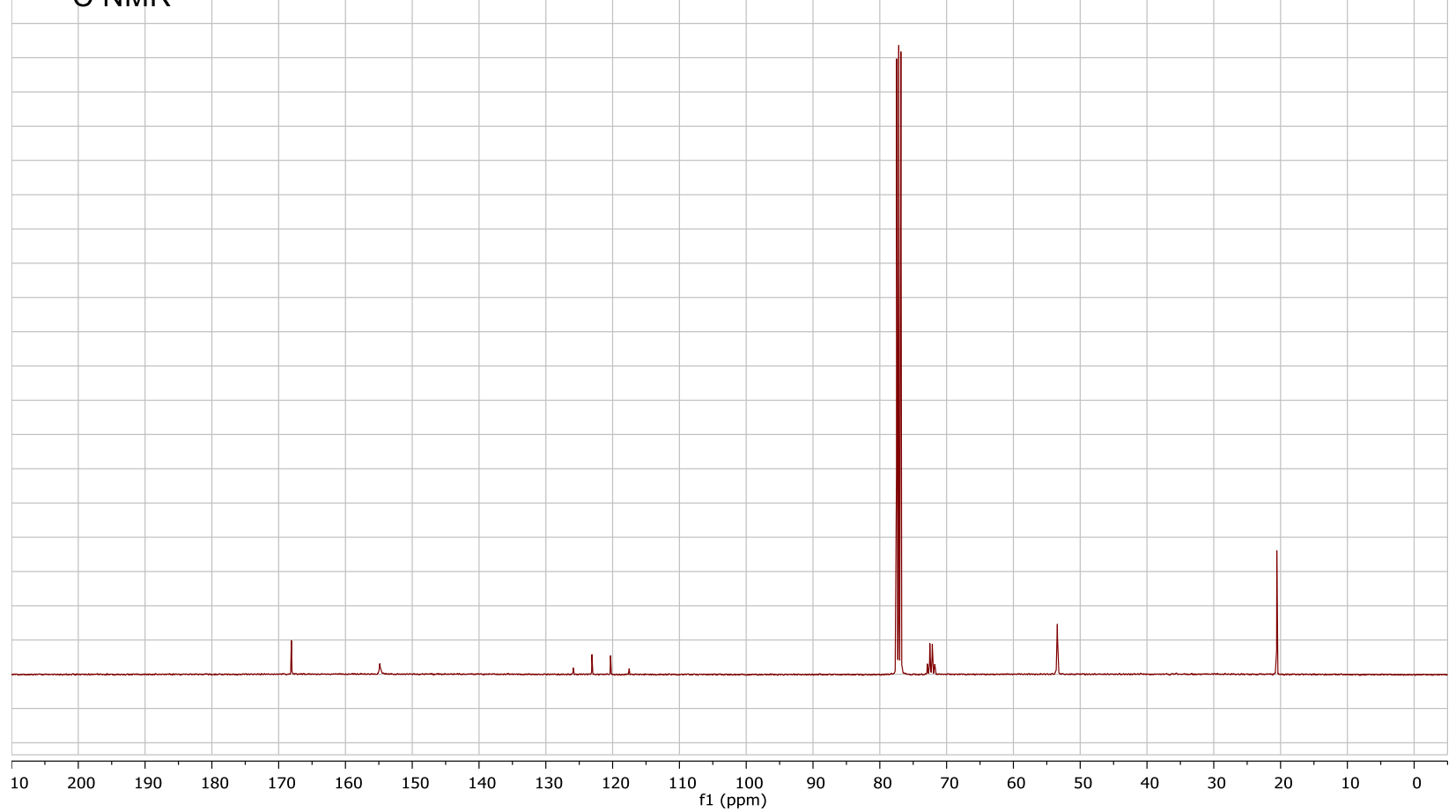




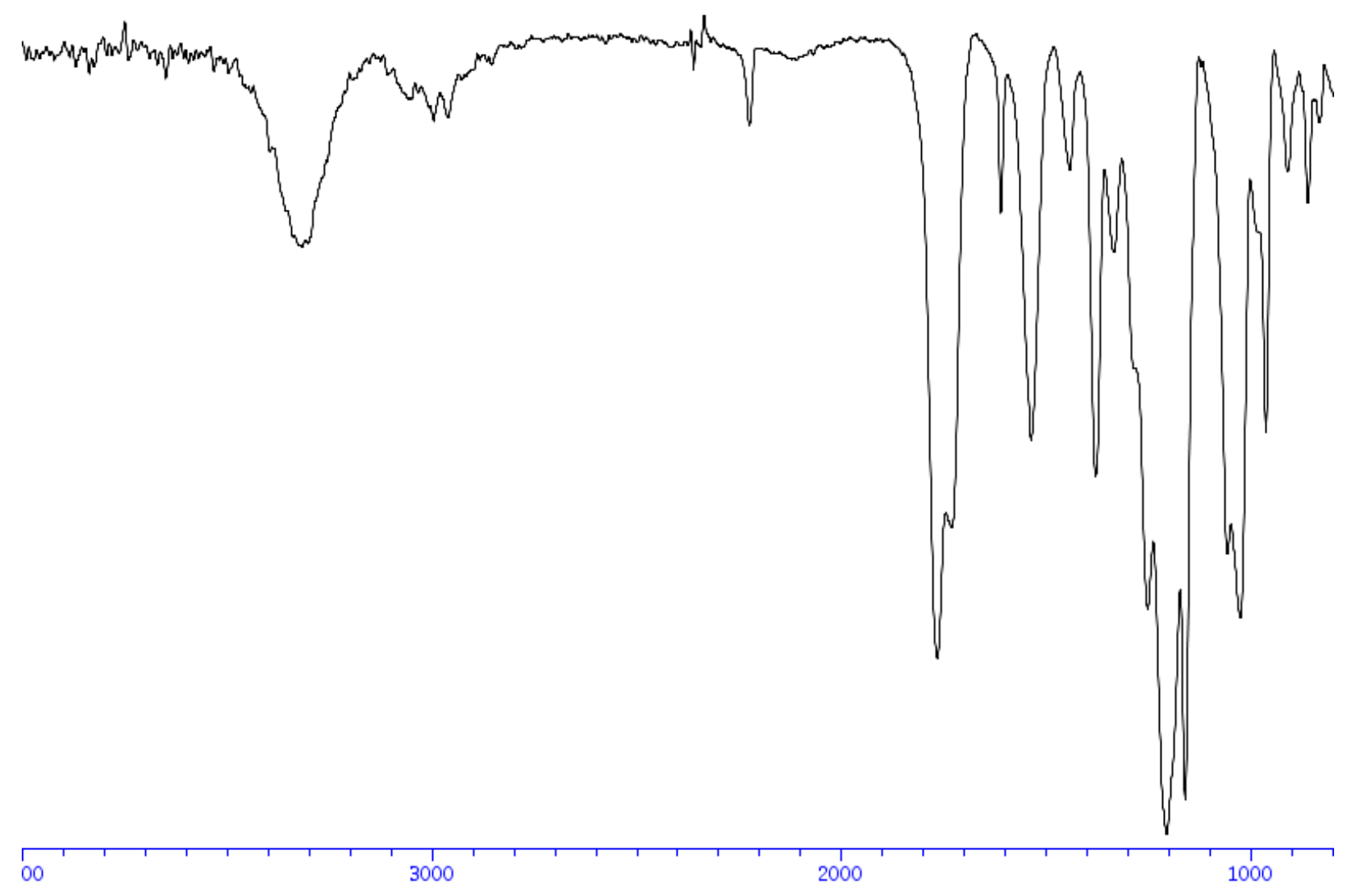




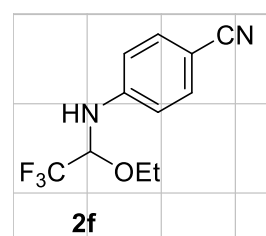

${ }^{1} \mathrm{H}$ NMR \begin{tabular}{|l|l|l|}
\hline$|+|$ & \\
\hline $\int$ &
\end{tabular}

||

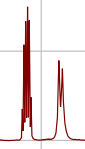

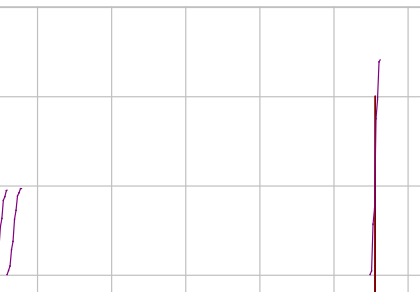
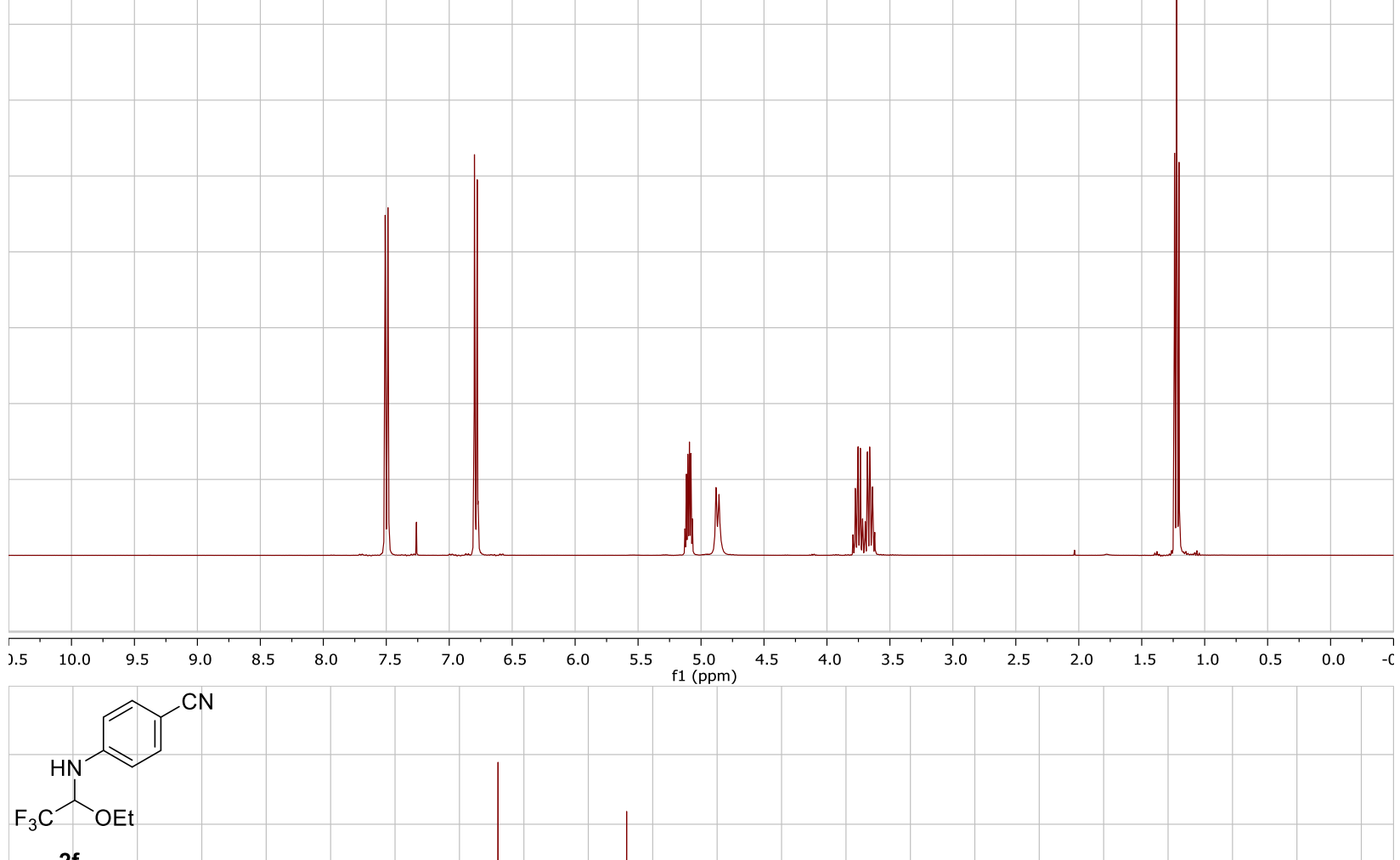

$2 f$

${ }^{13} \mathrm{C}$ NMR 


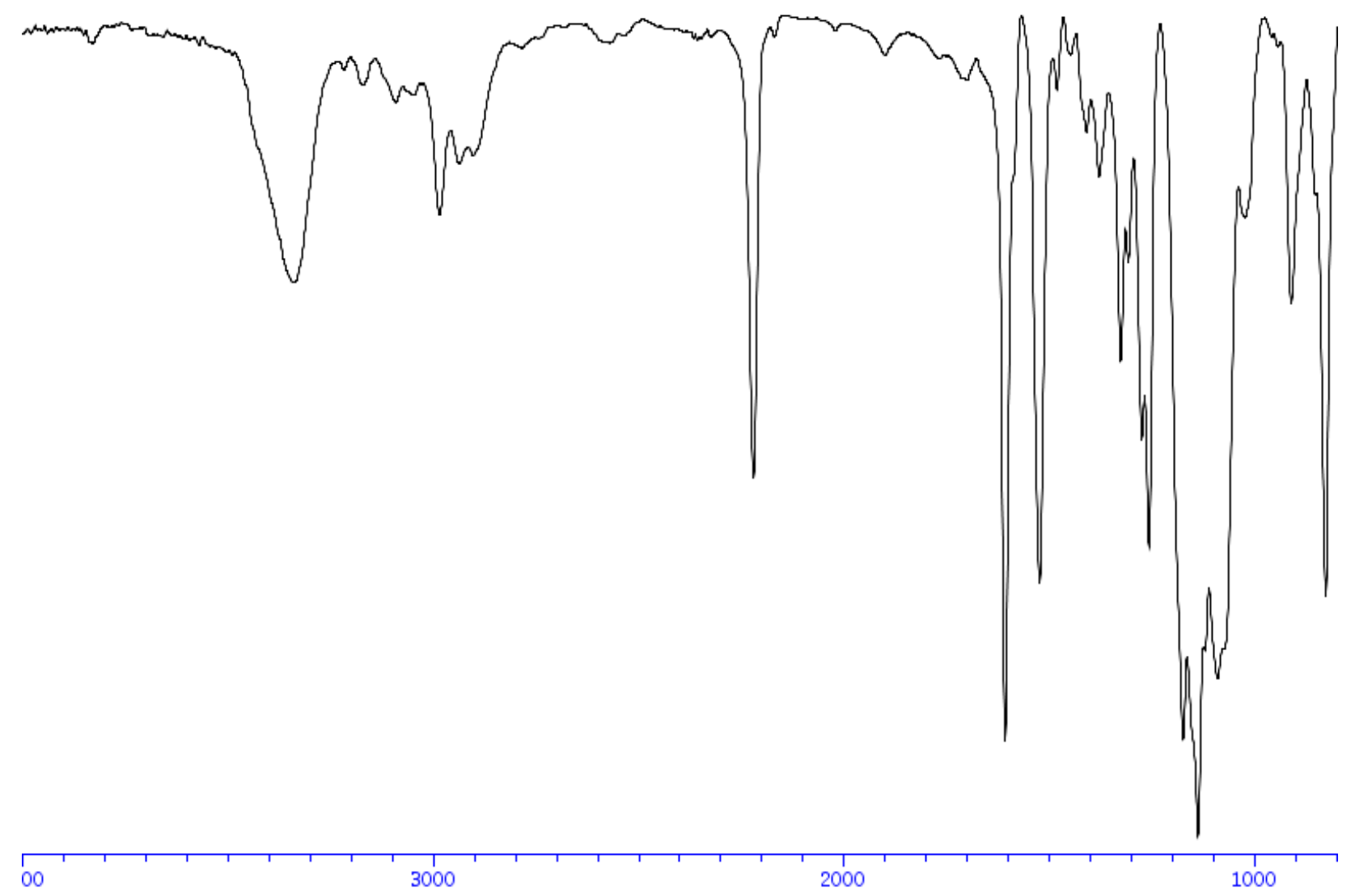




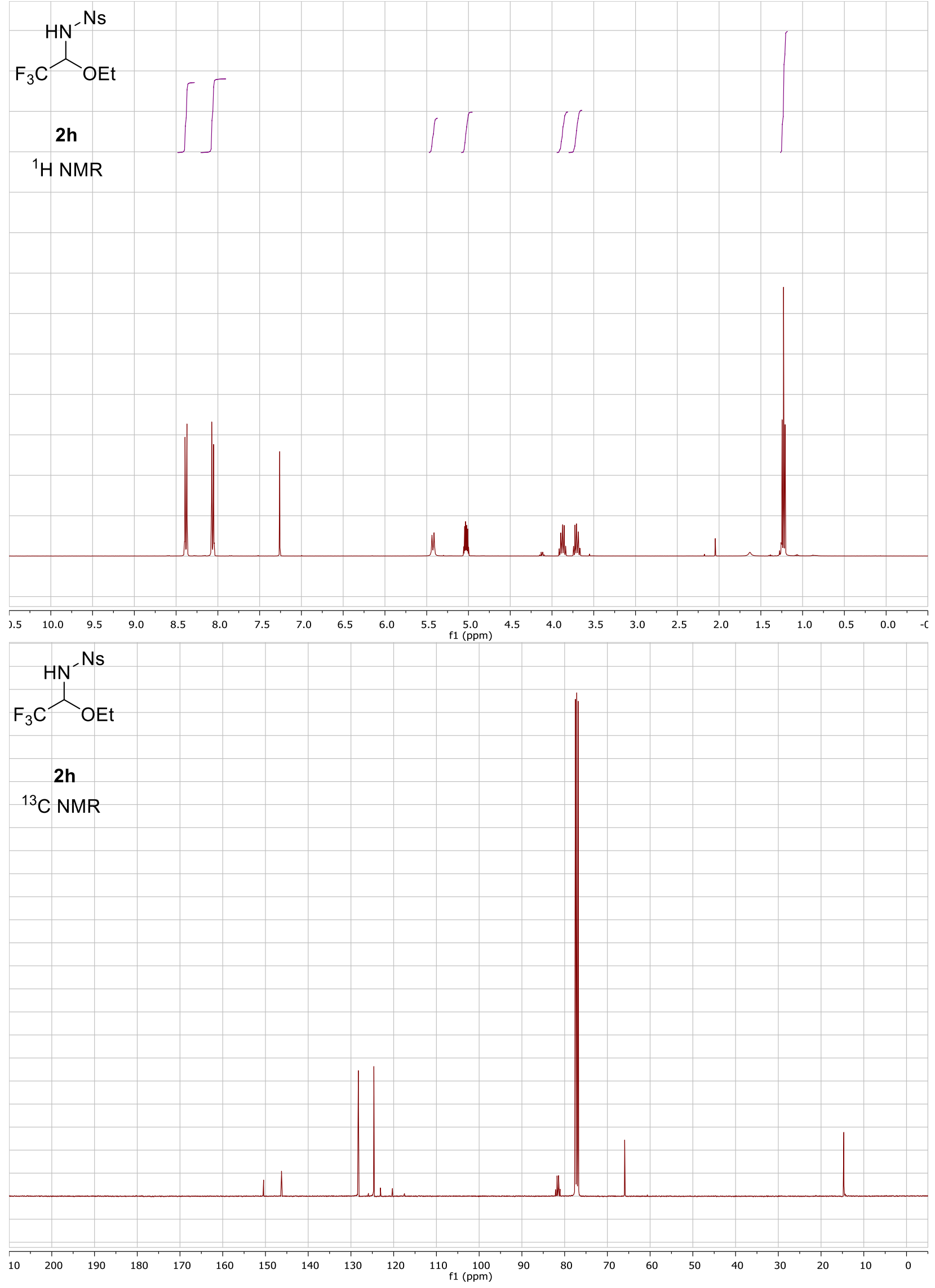




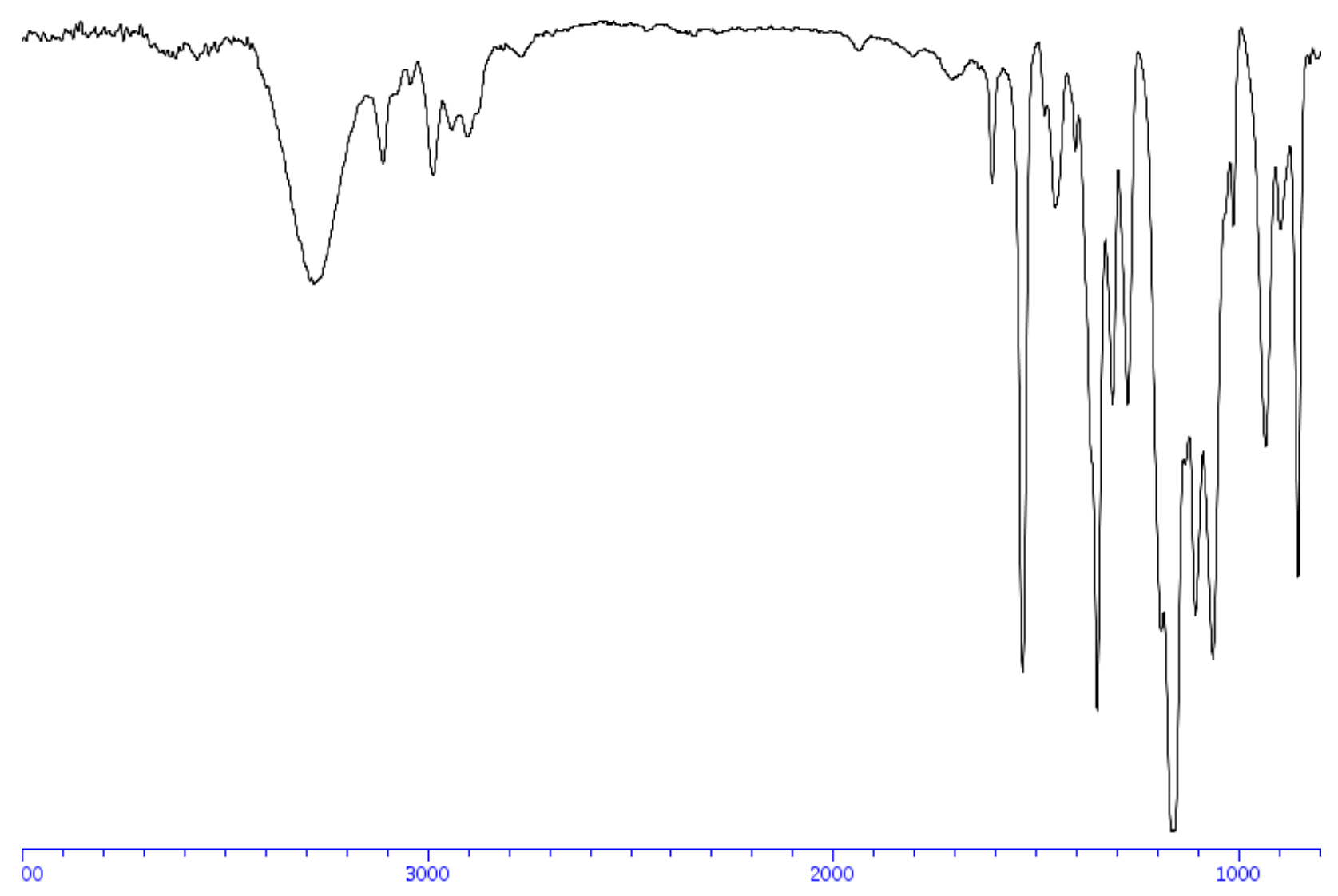



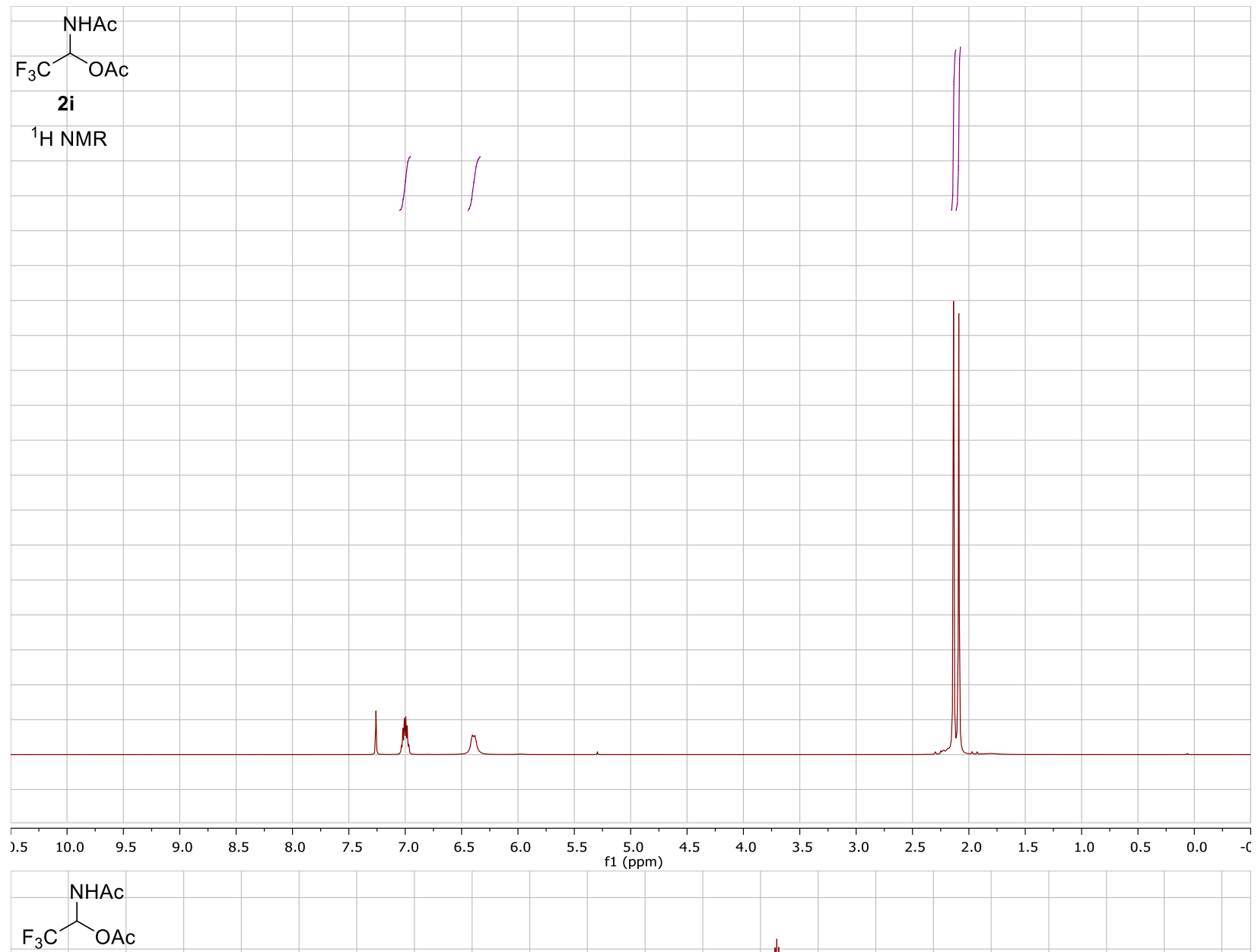

$2 i$

${ }^{13} \mathrm{C}$ NMR

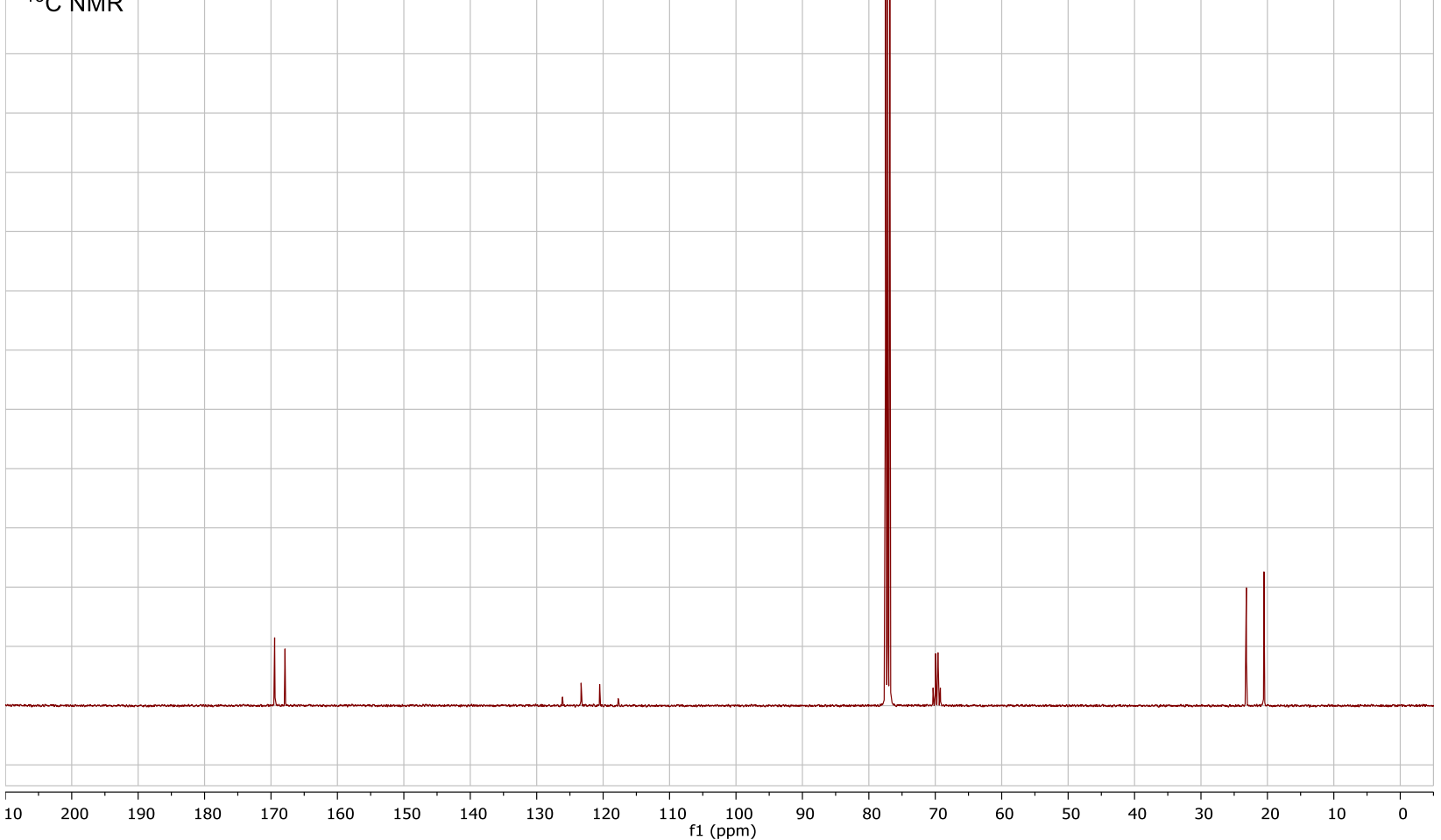




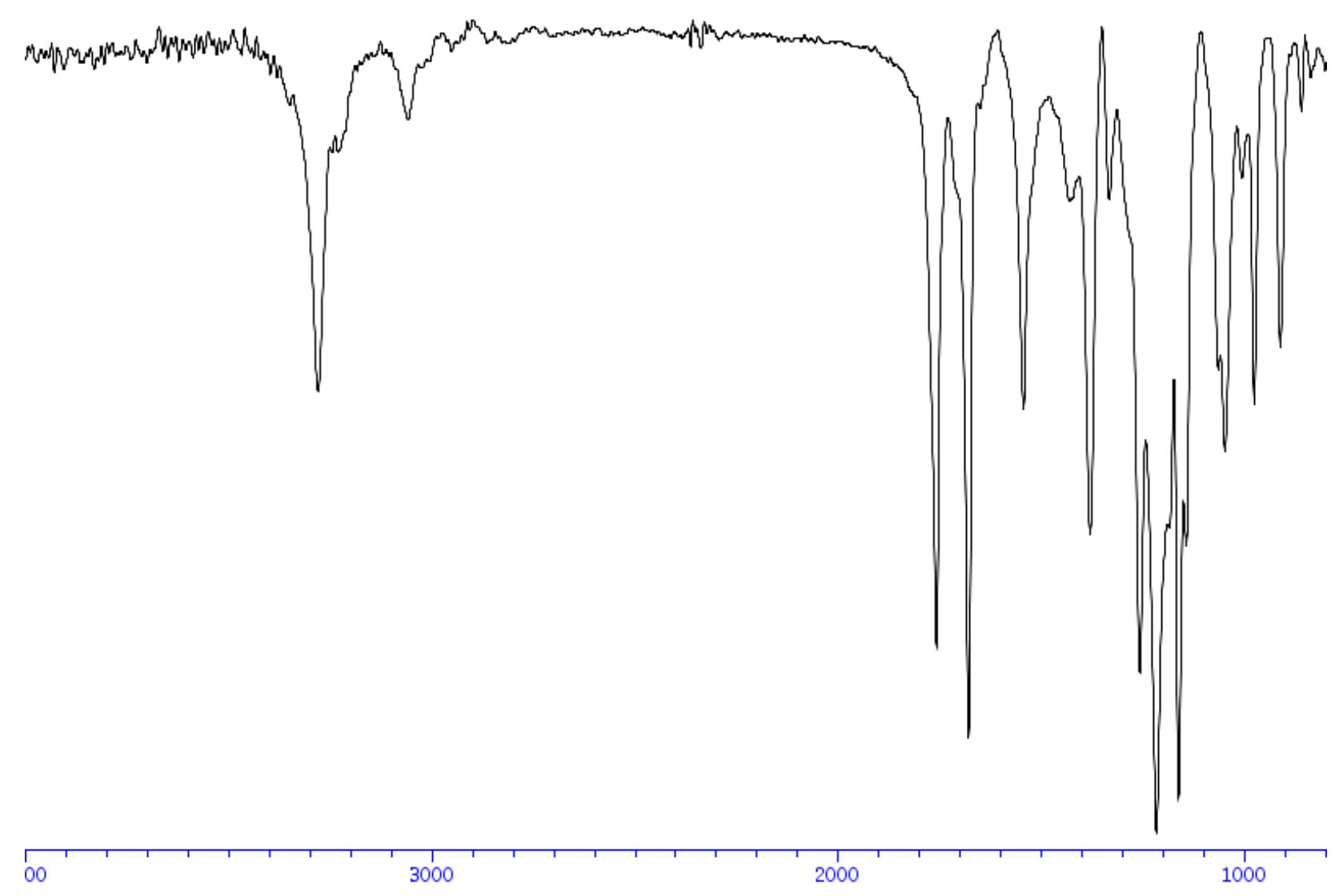



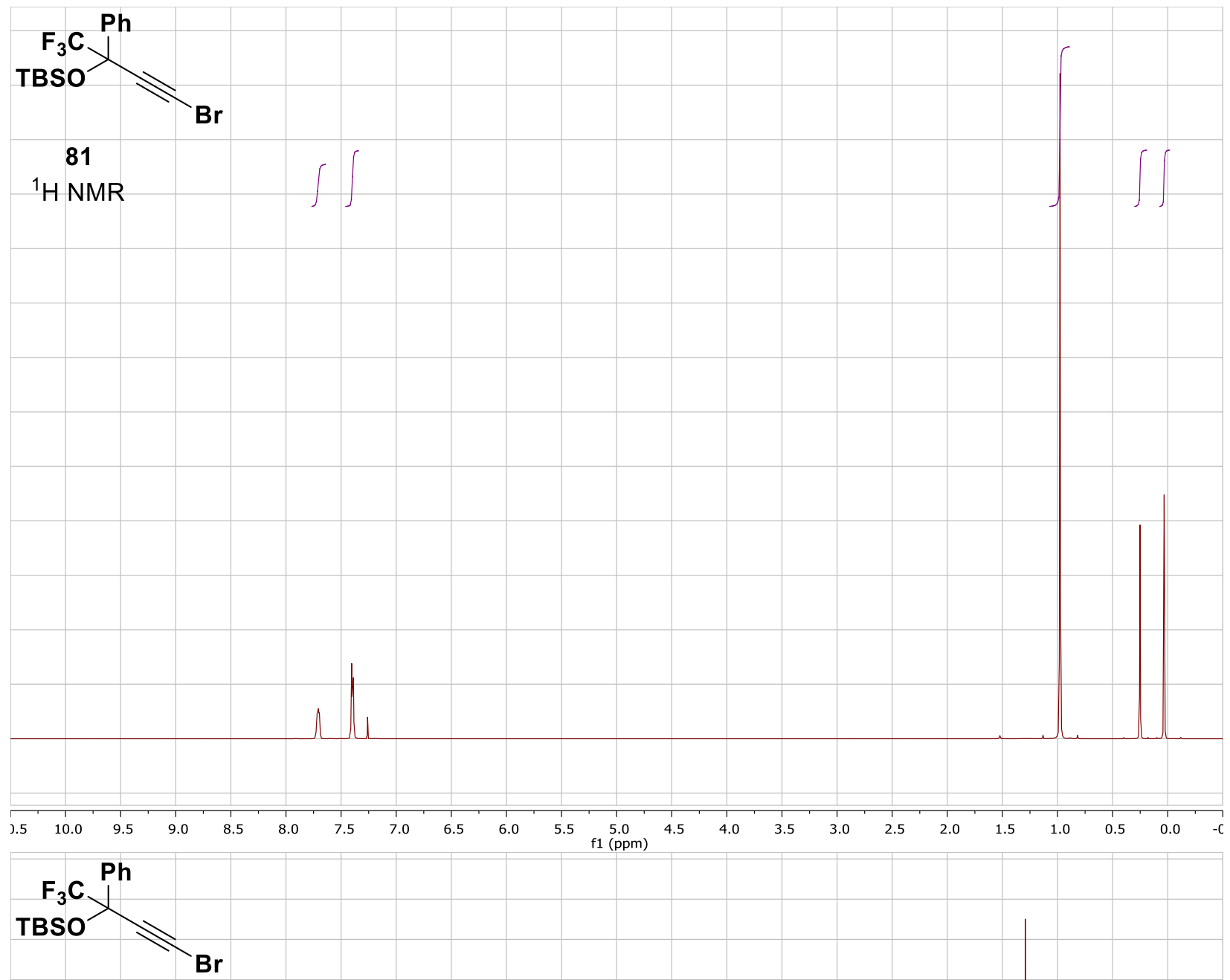

81

${ }^{13} \mathrm{C}$ NMR

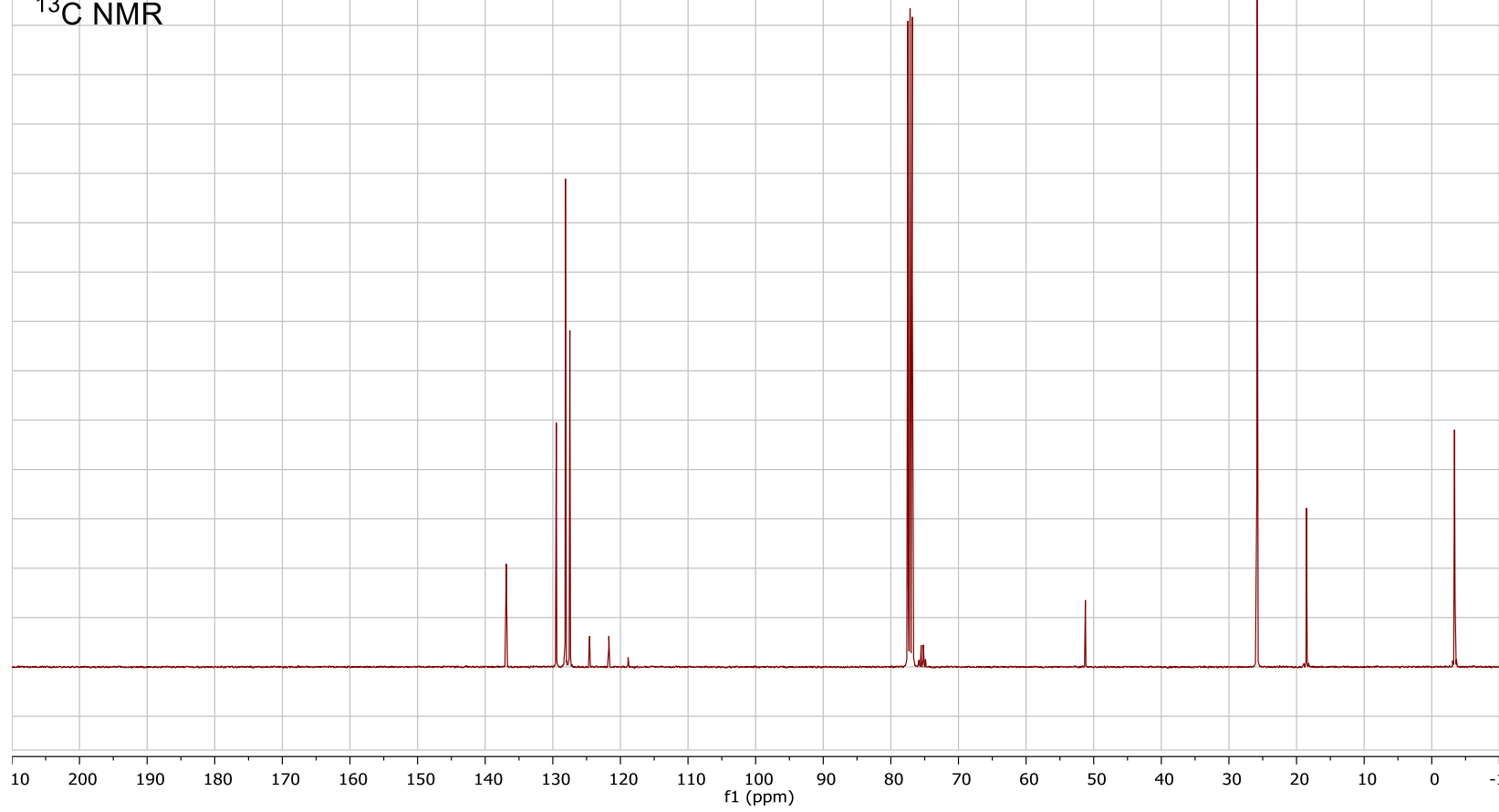




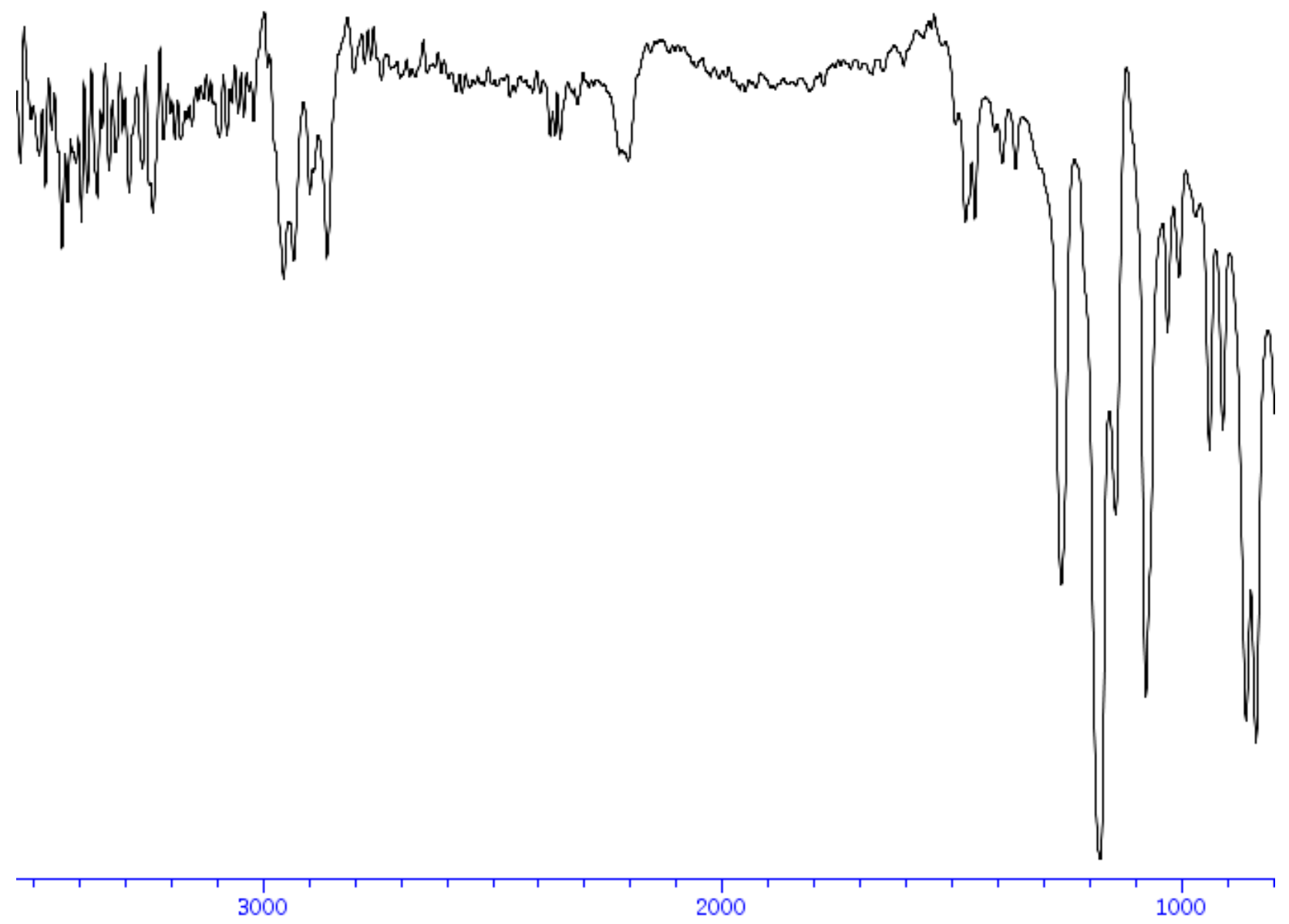

S70 

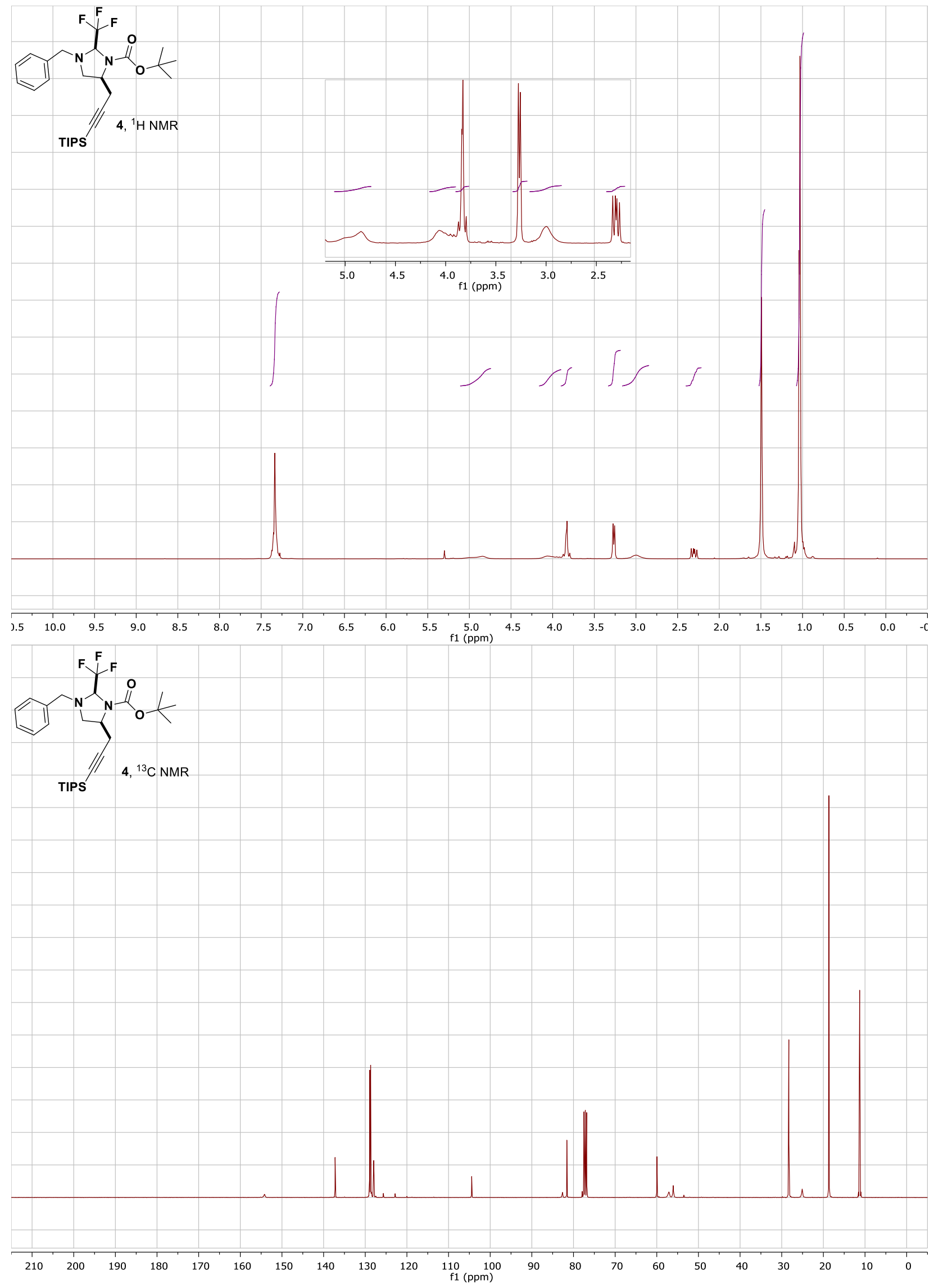

S71 


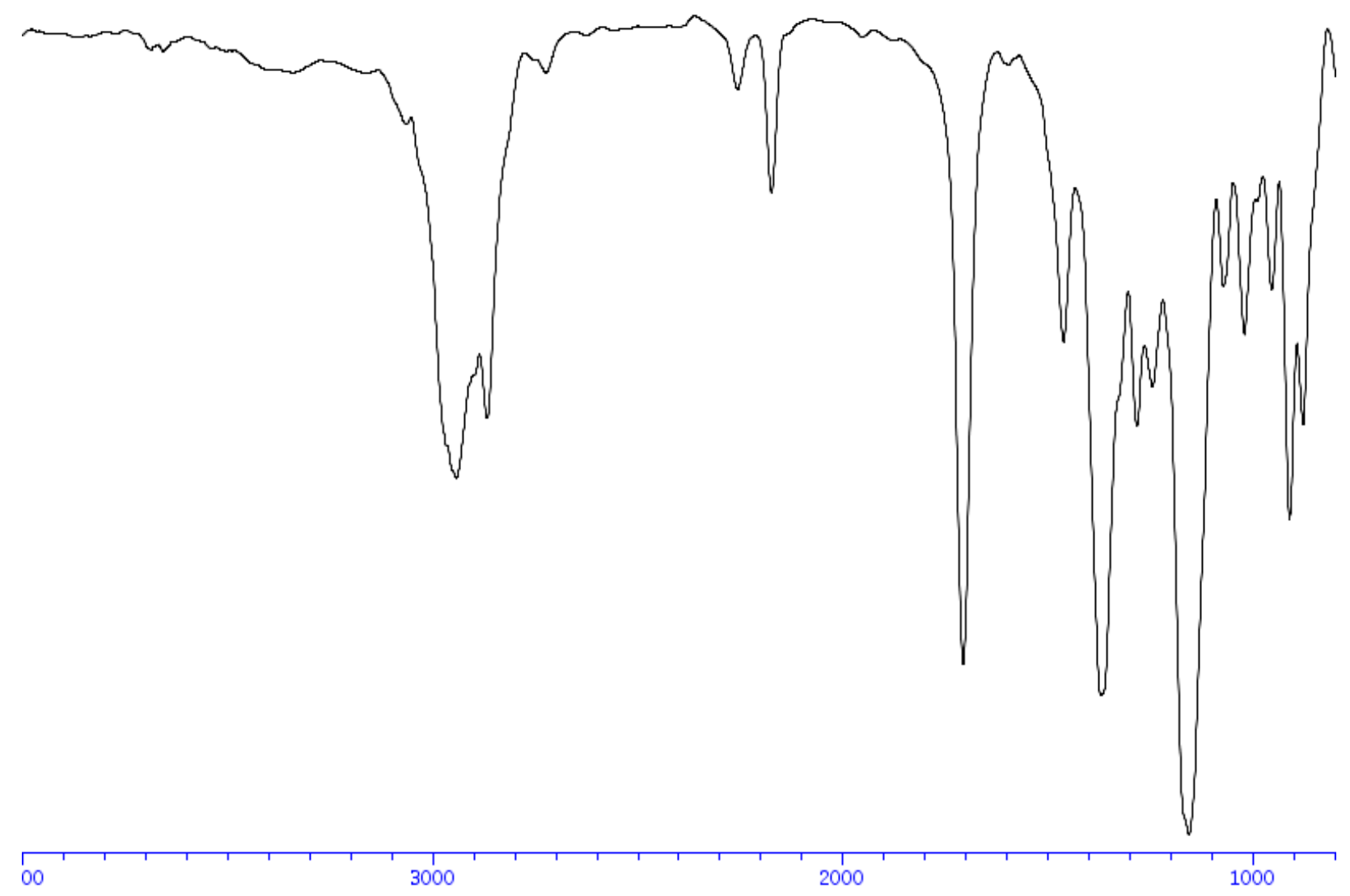



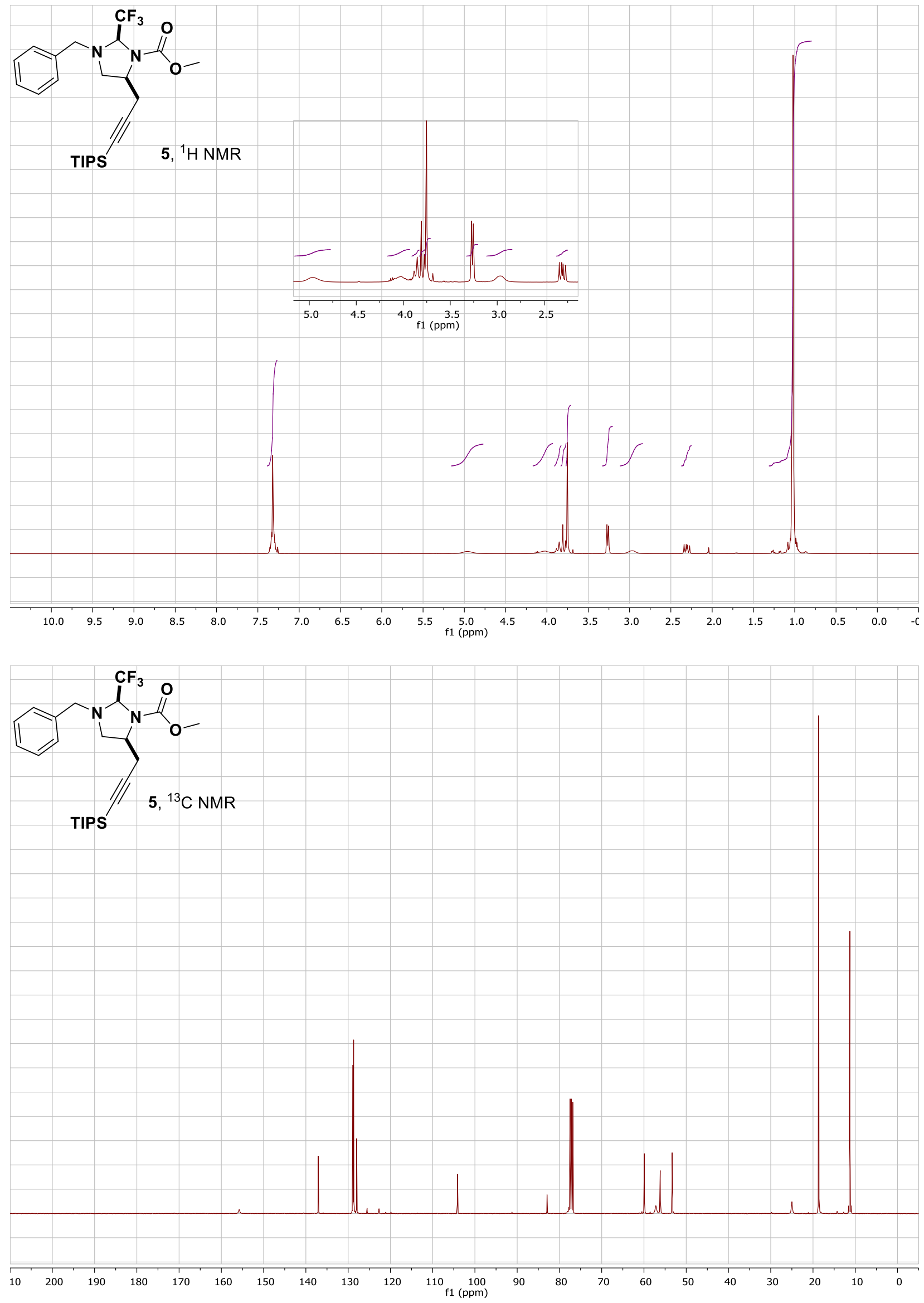


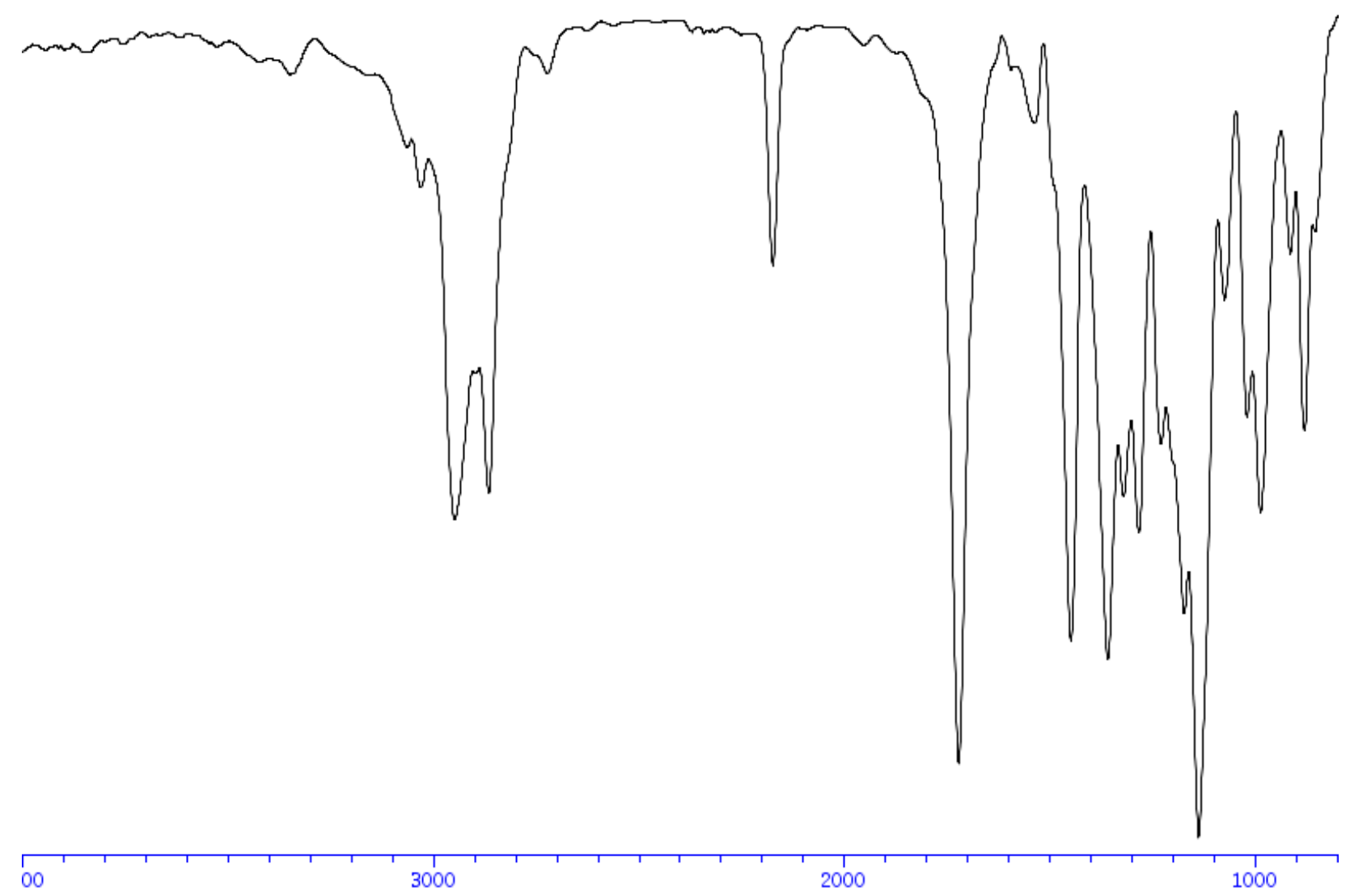



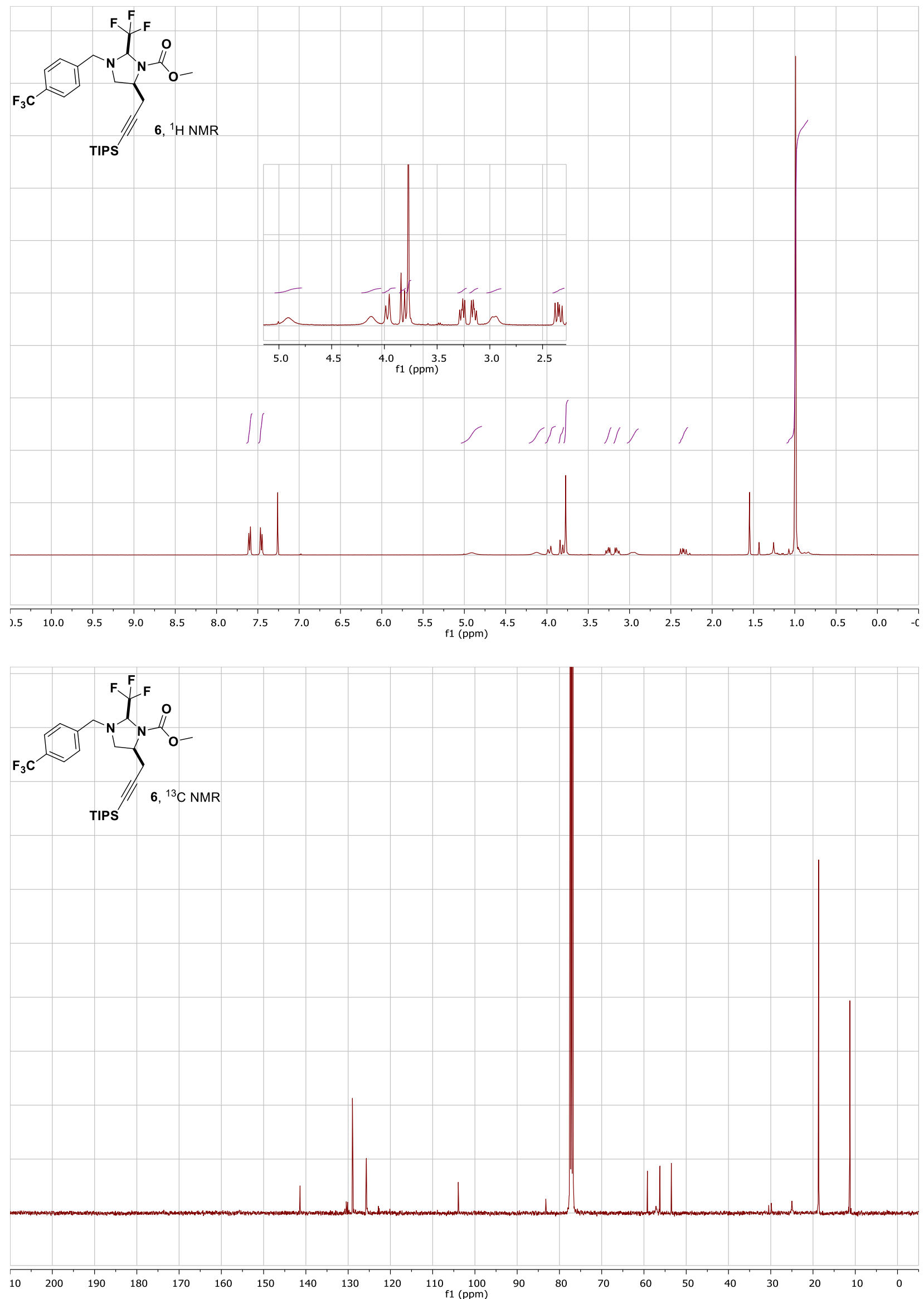


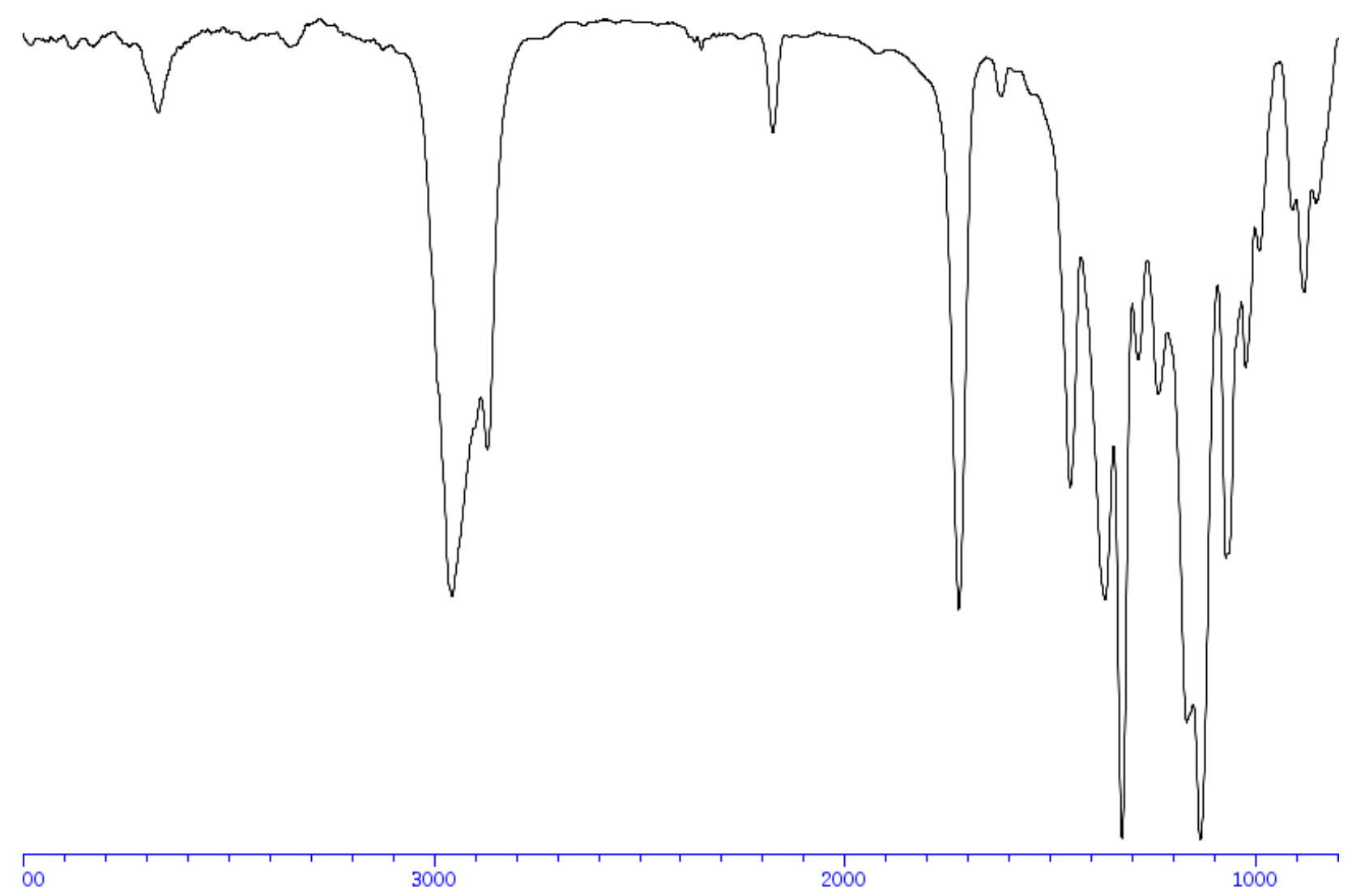



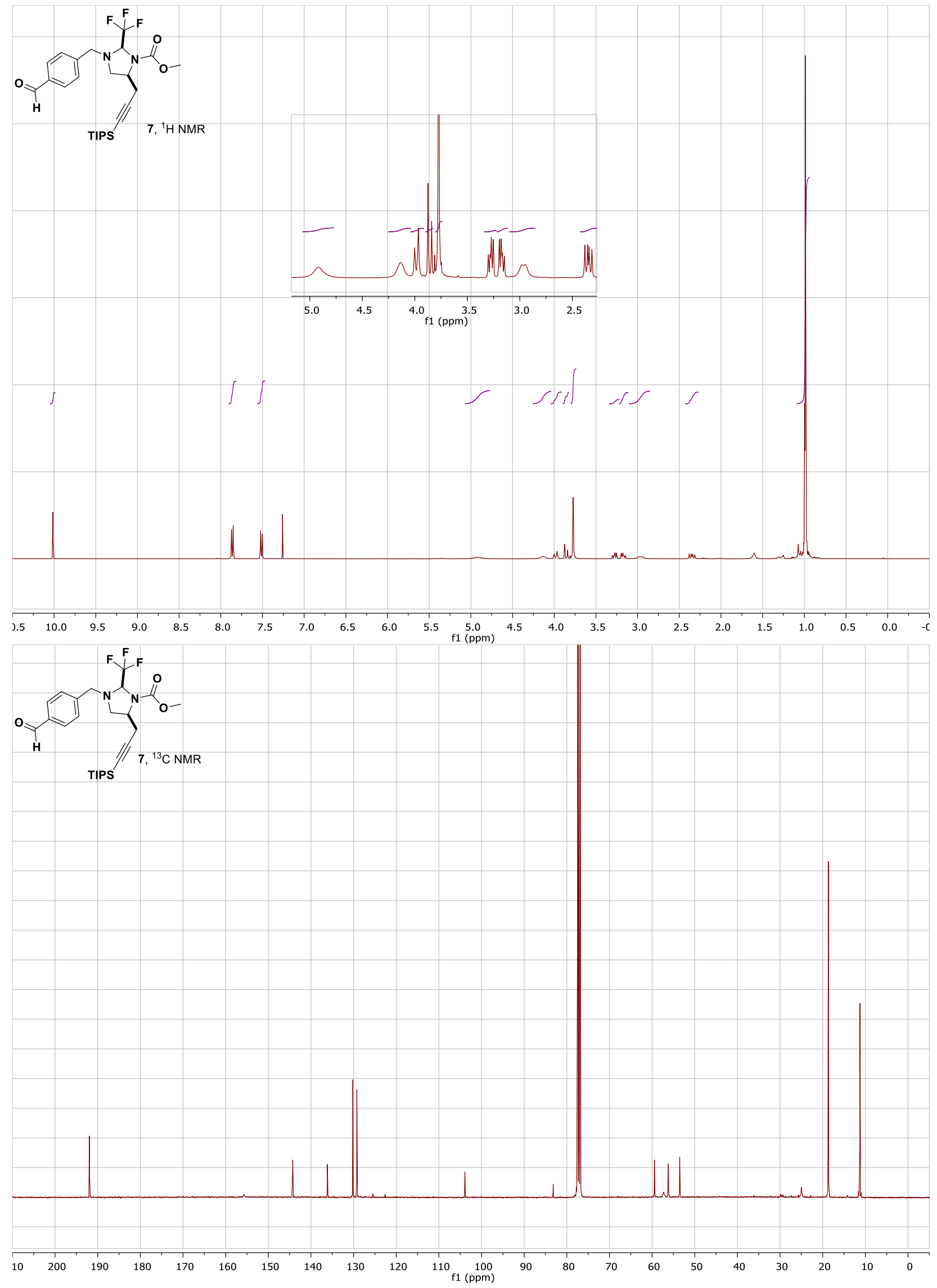

S77 


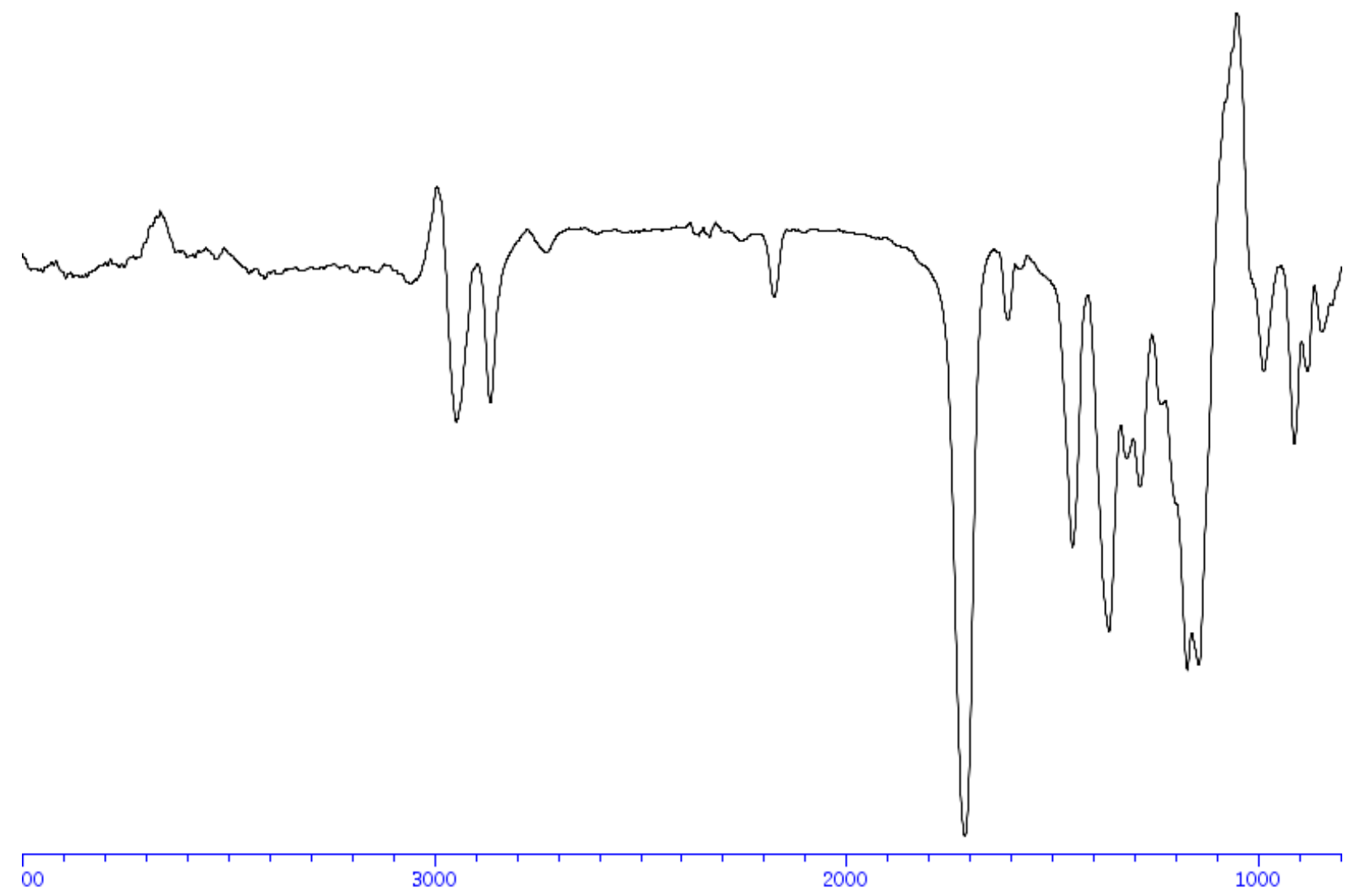



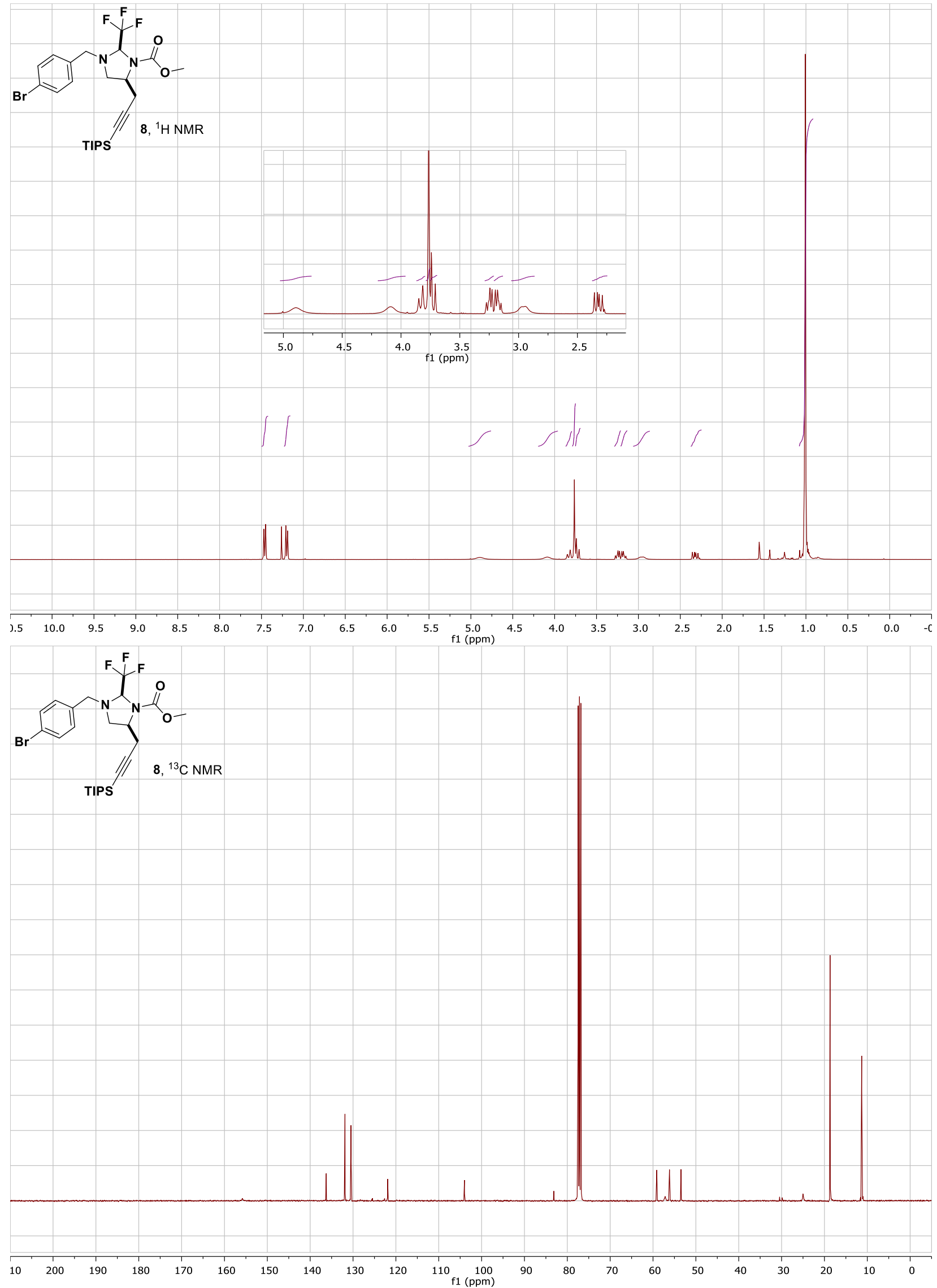


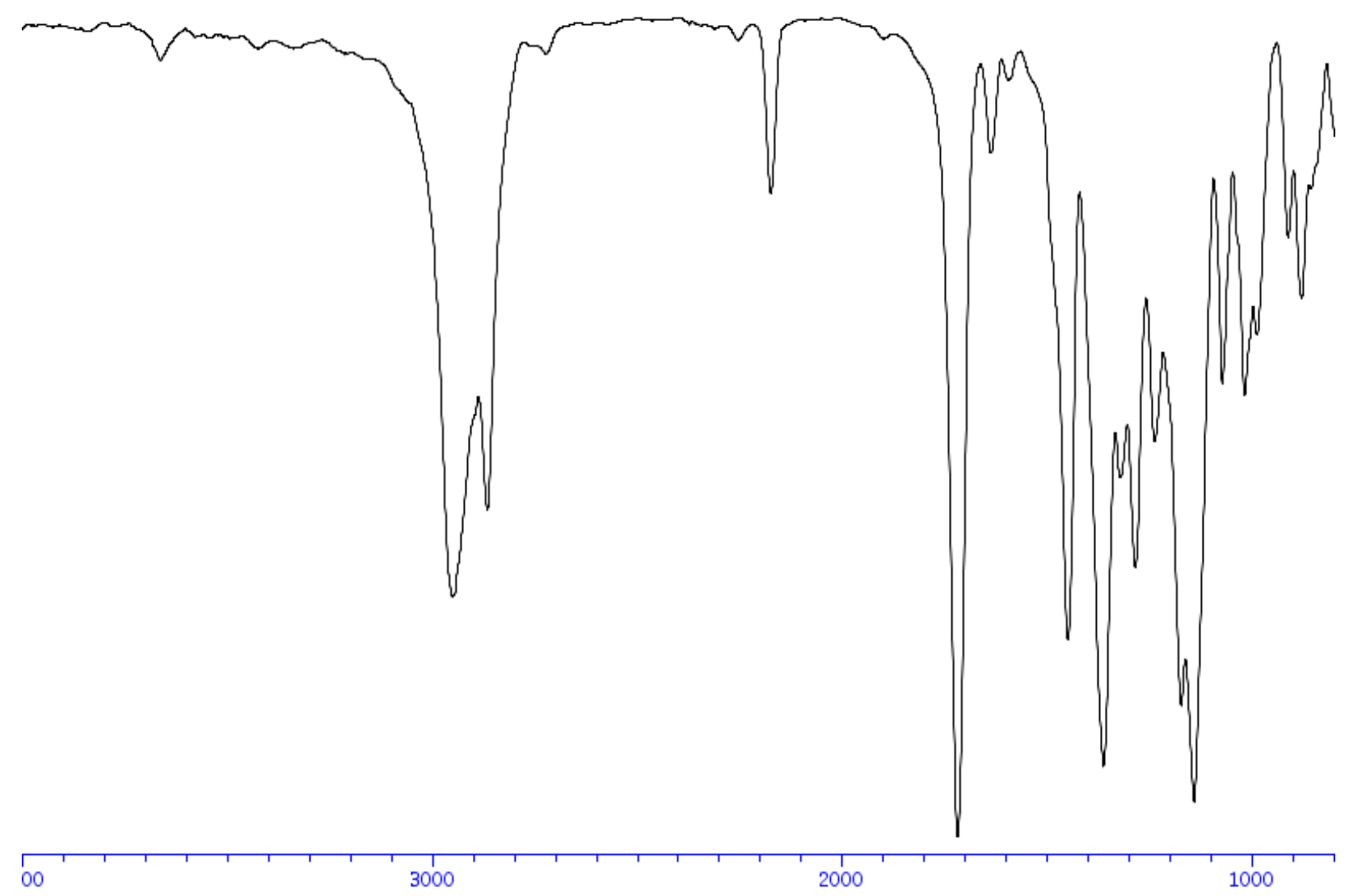




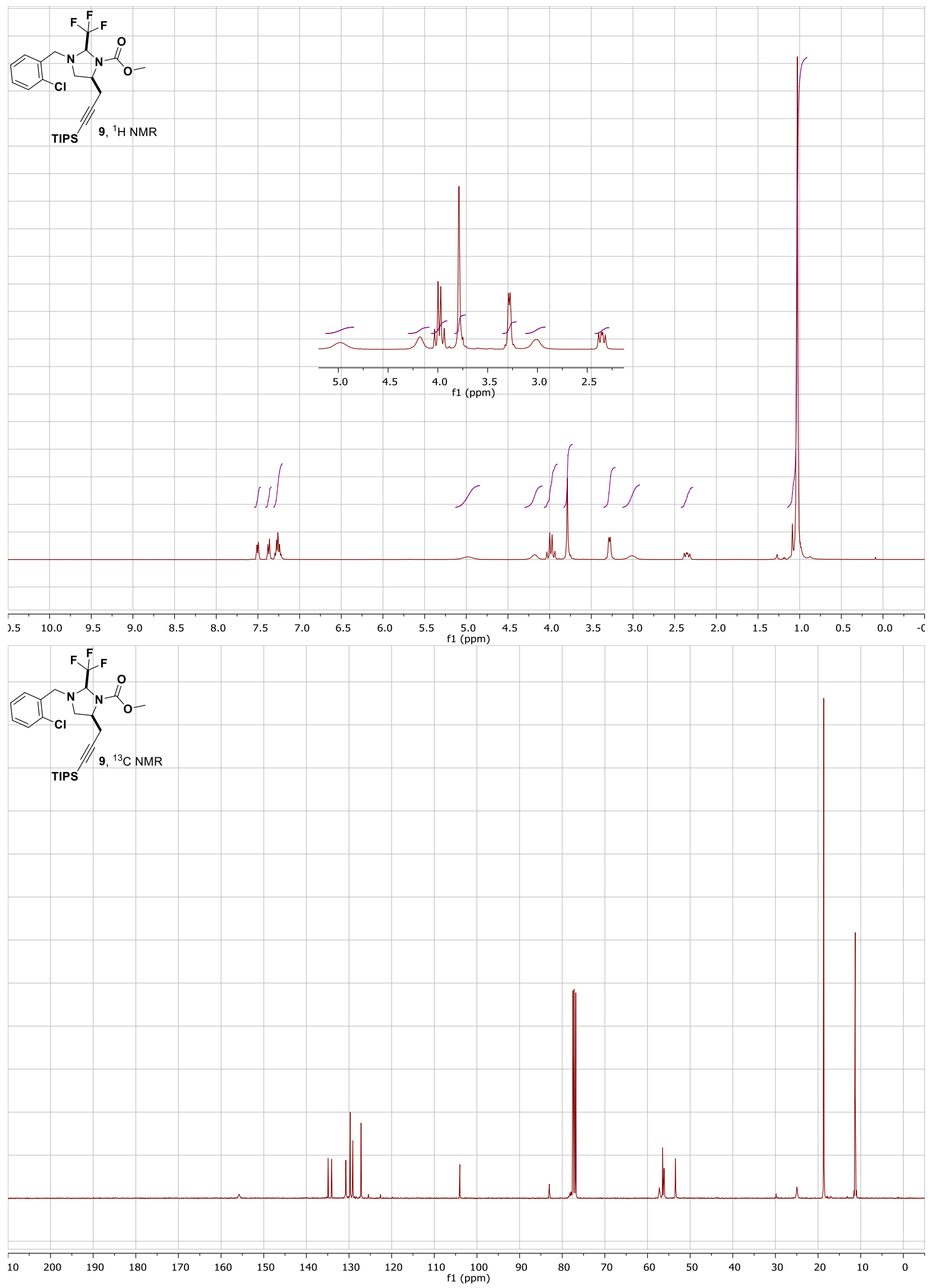




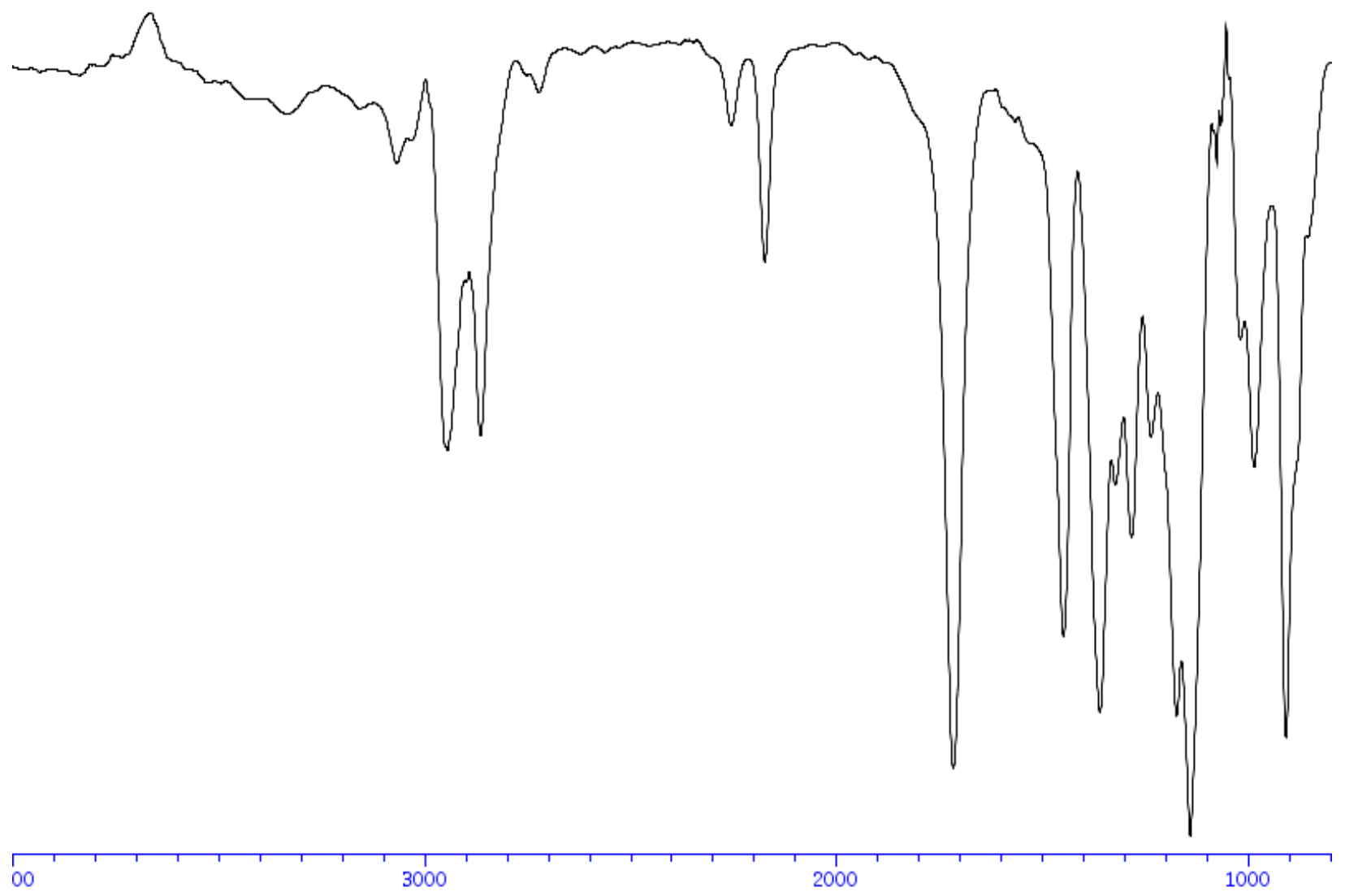



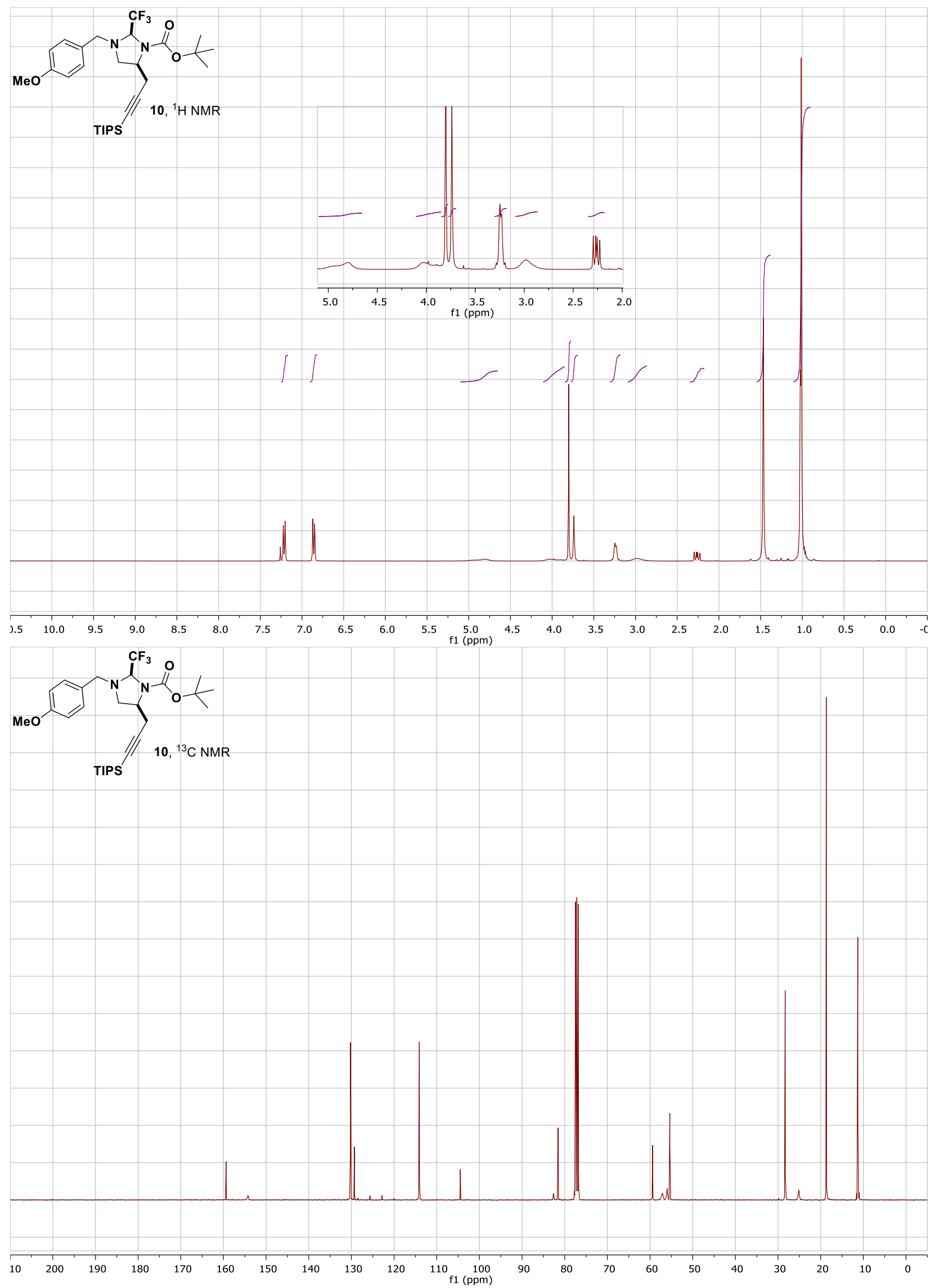


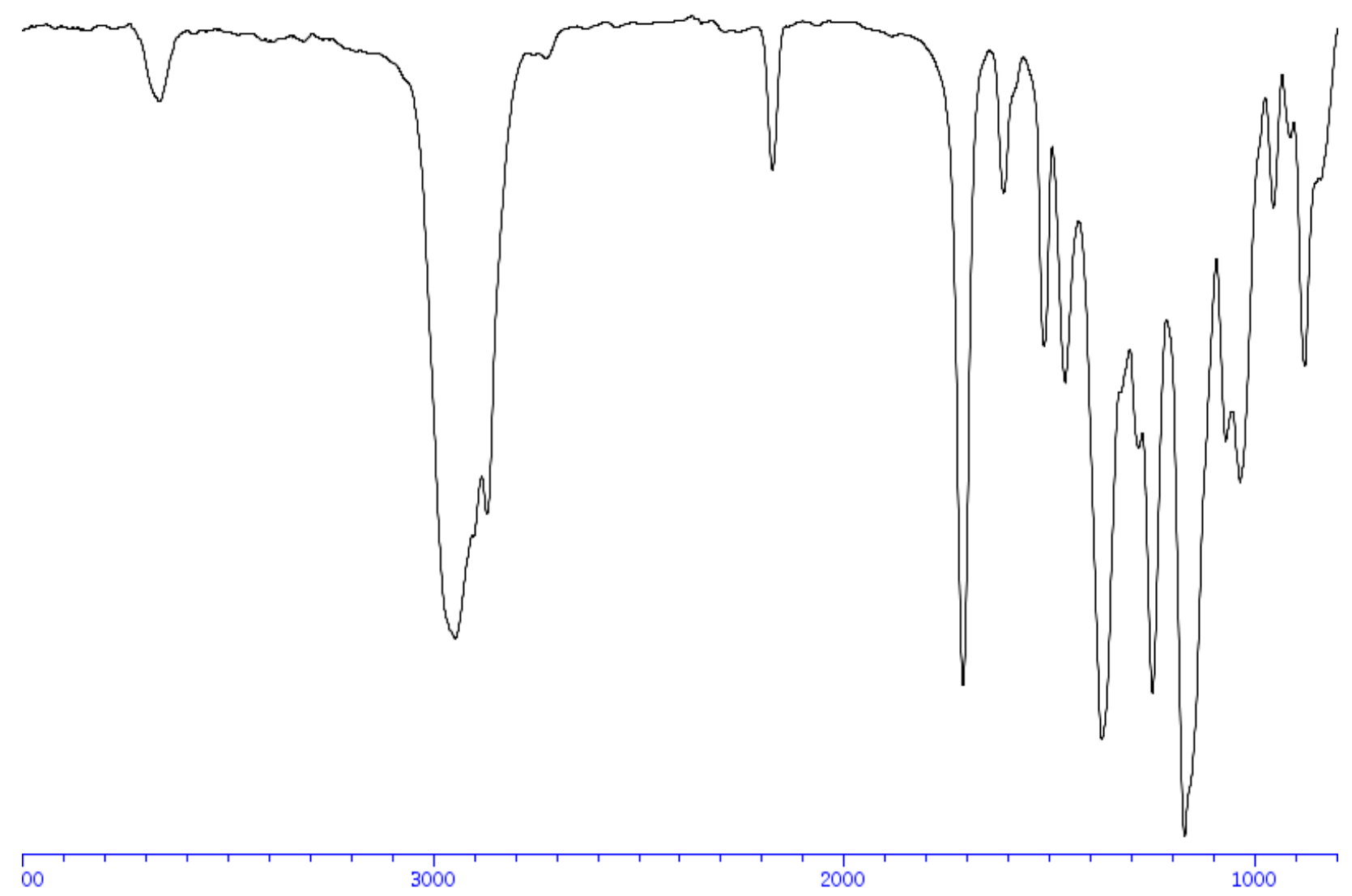



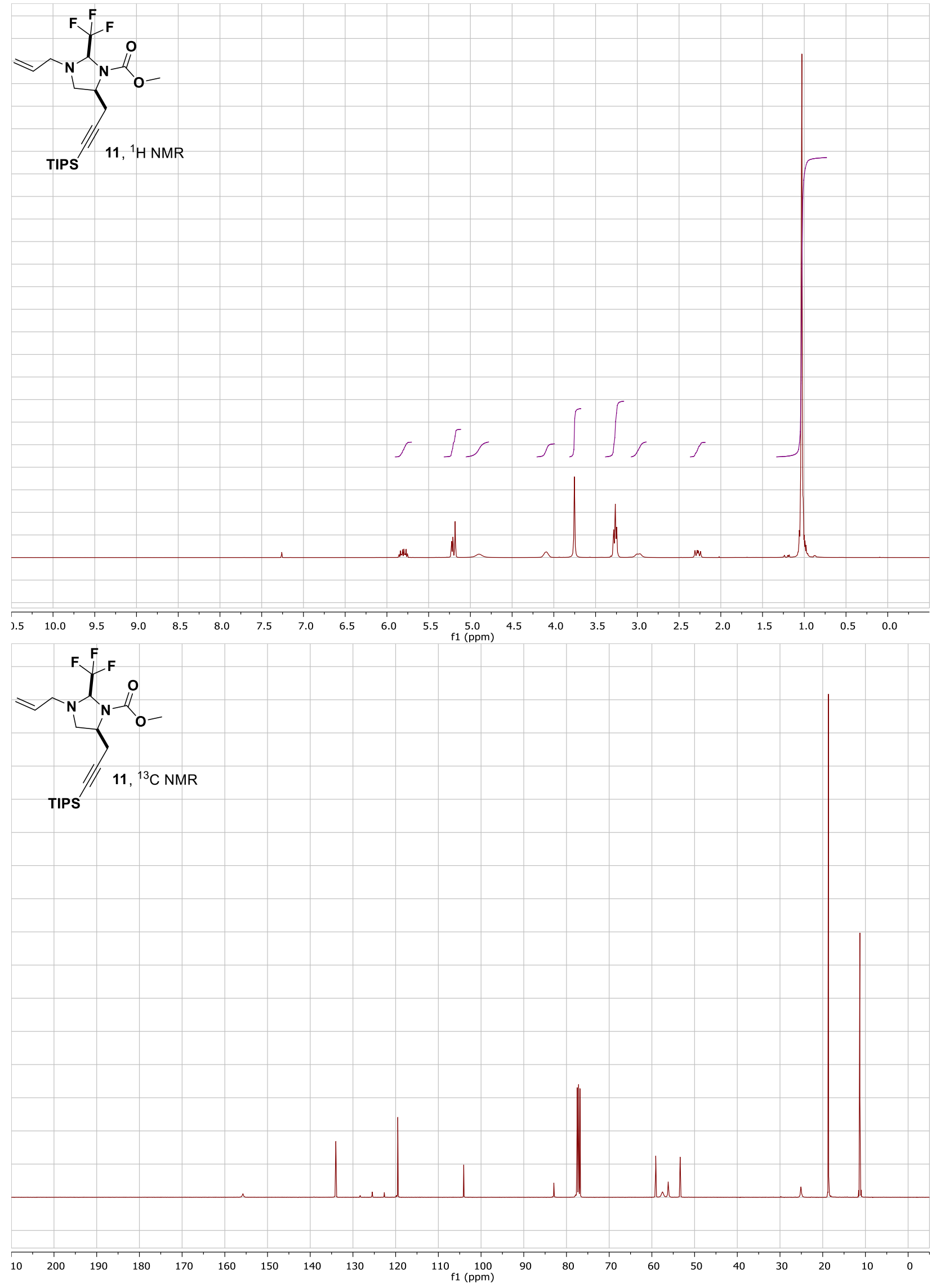

S85 


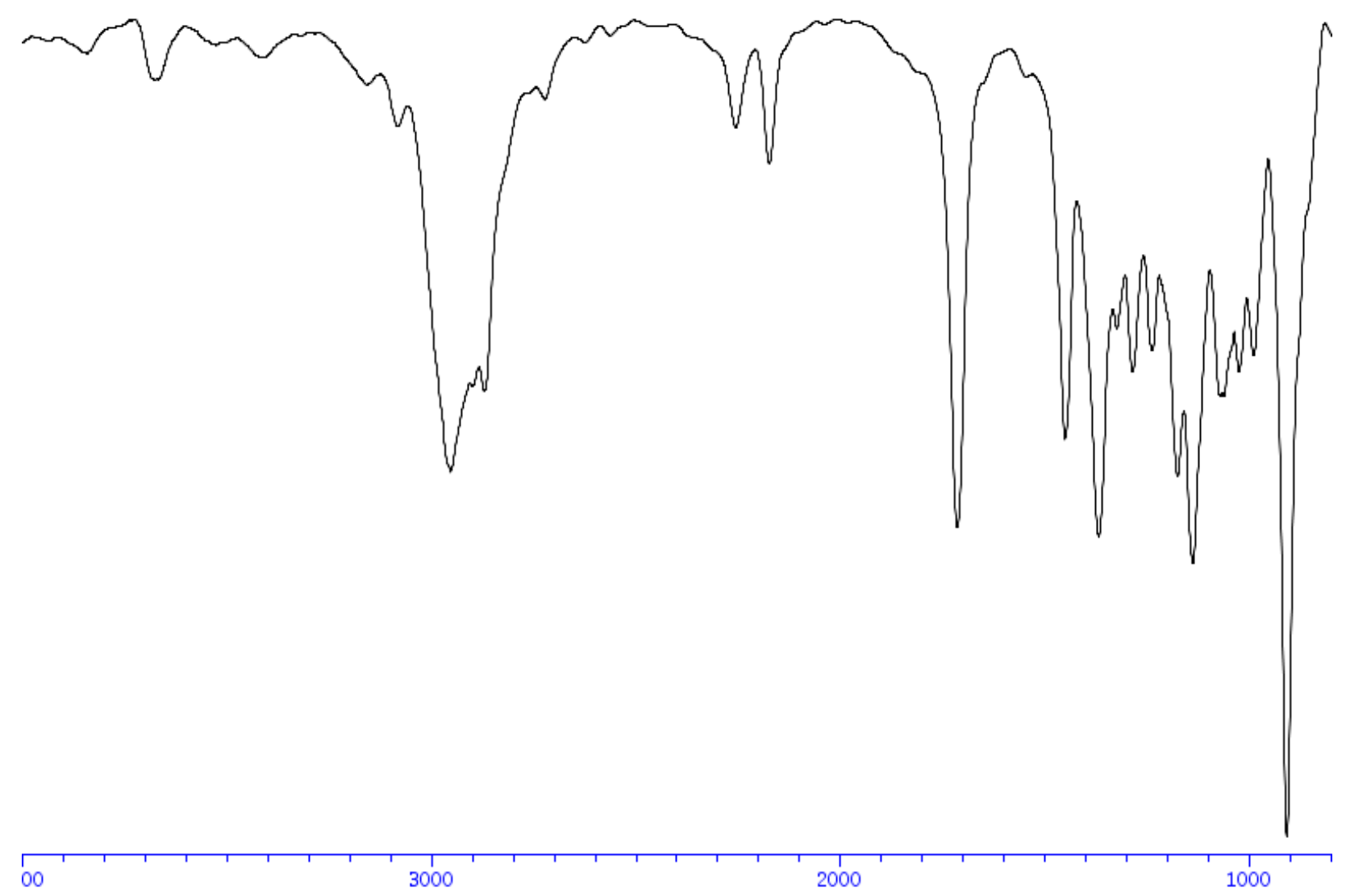



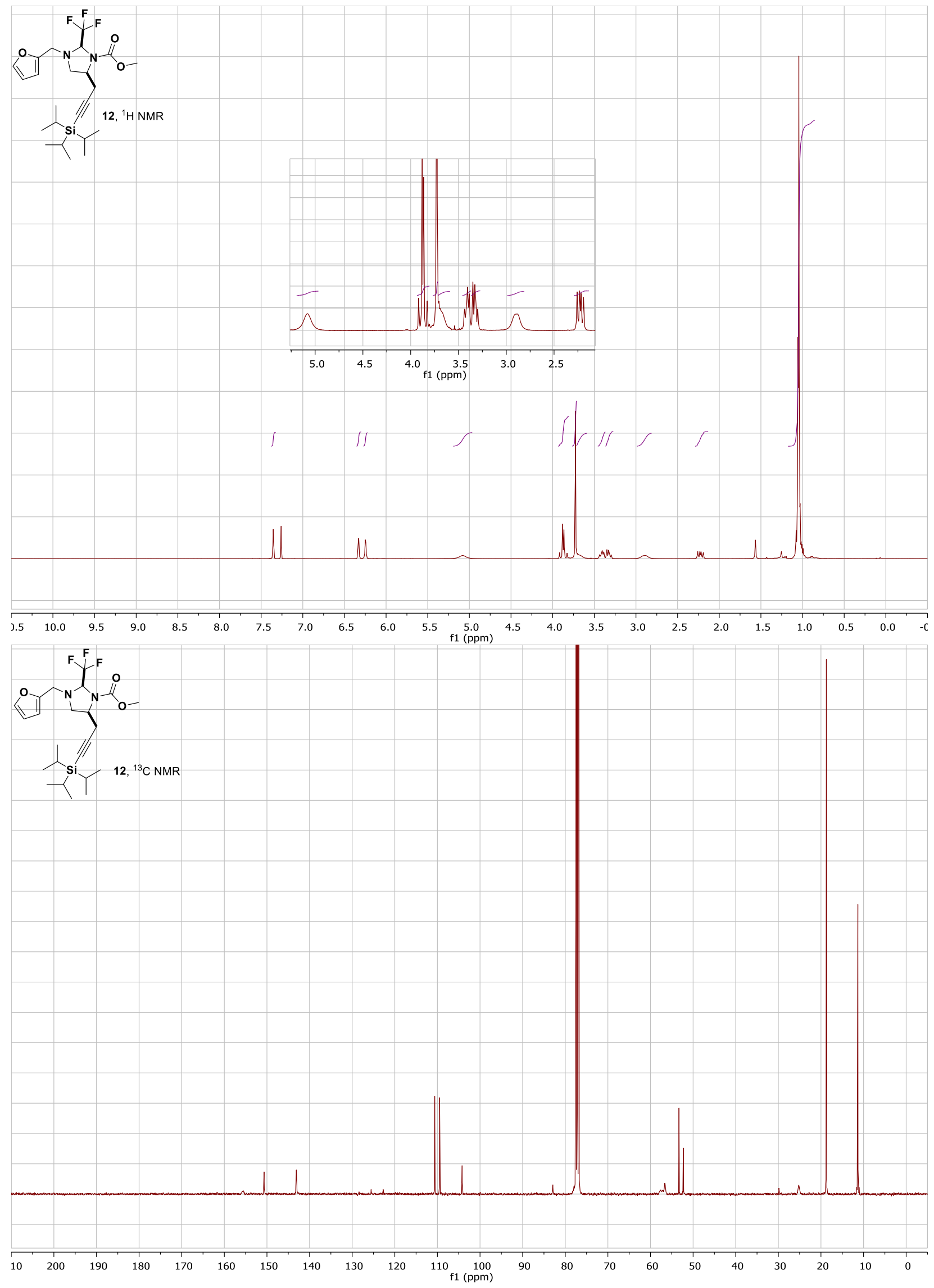

S87 


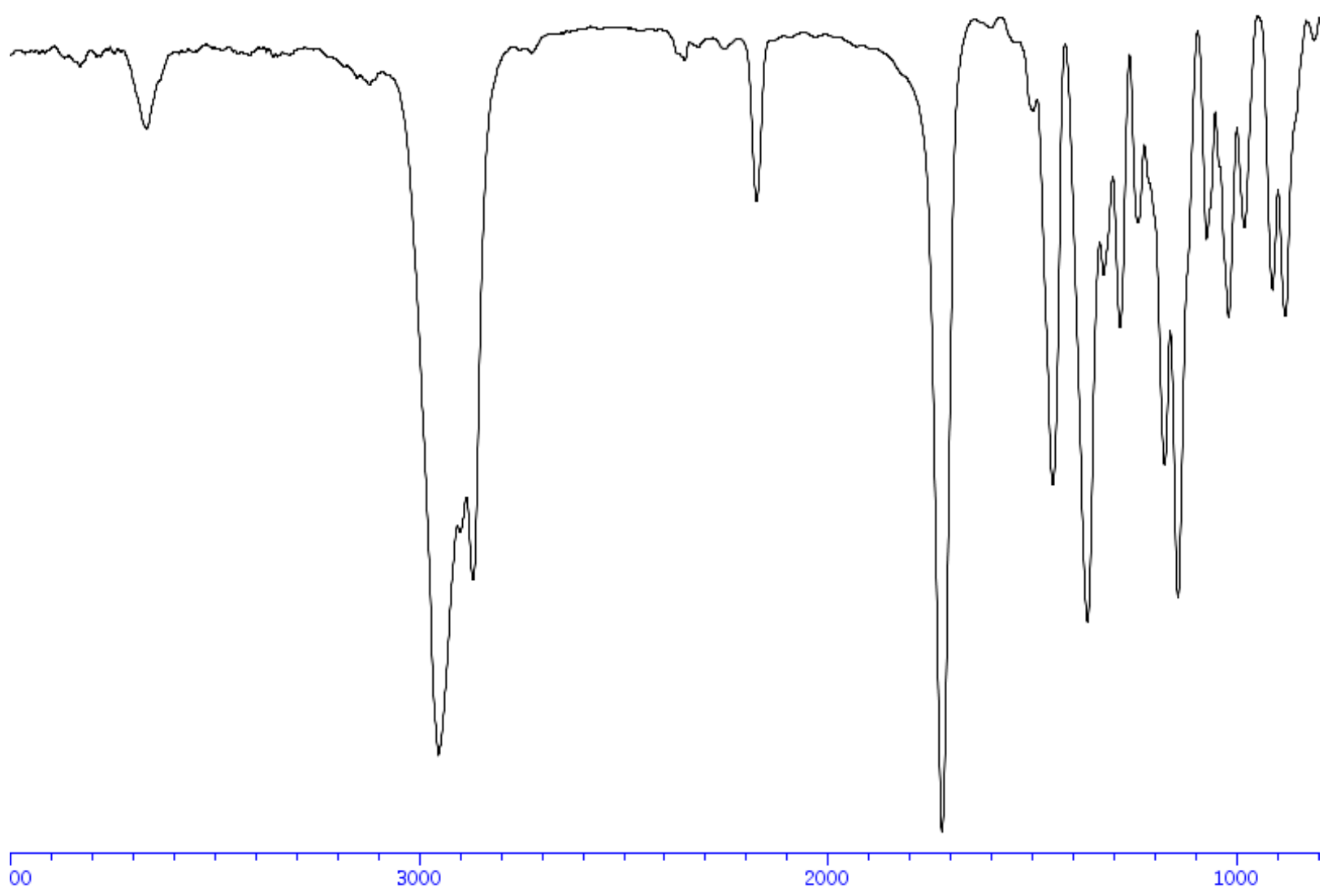



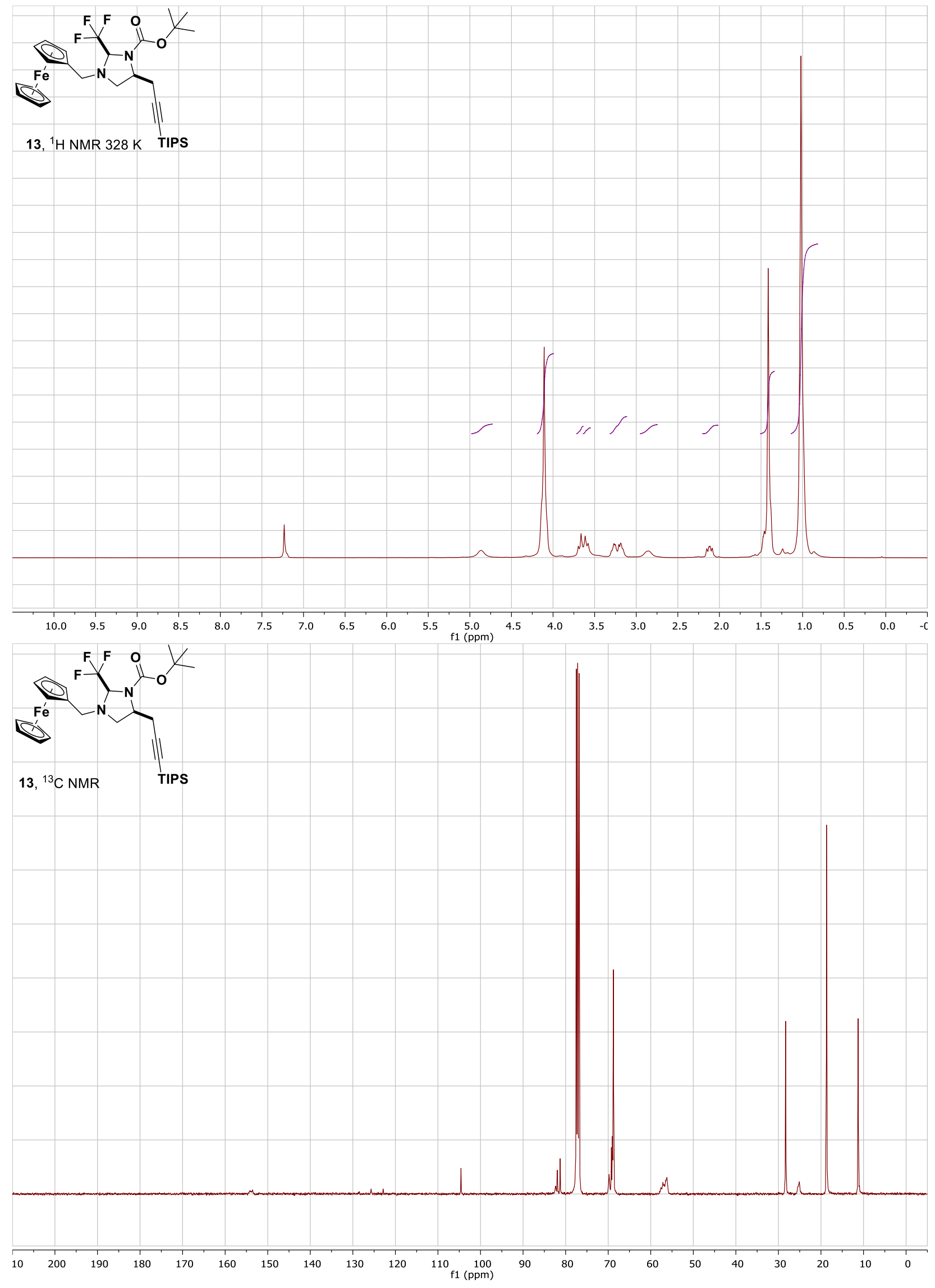

S89 


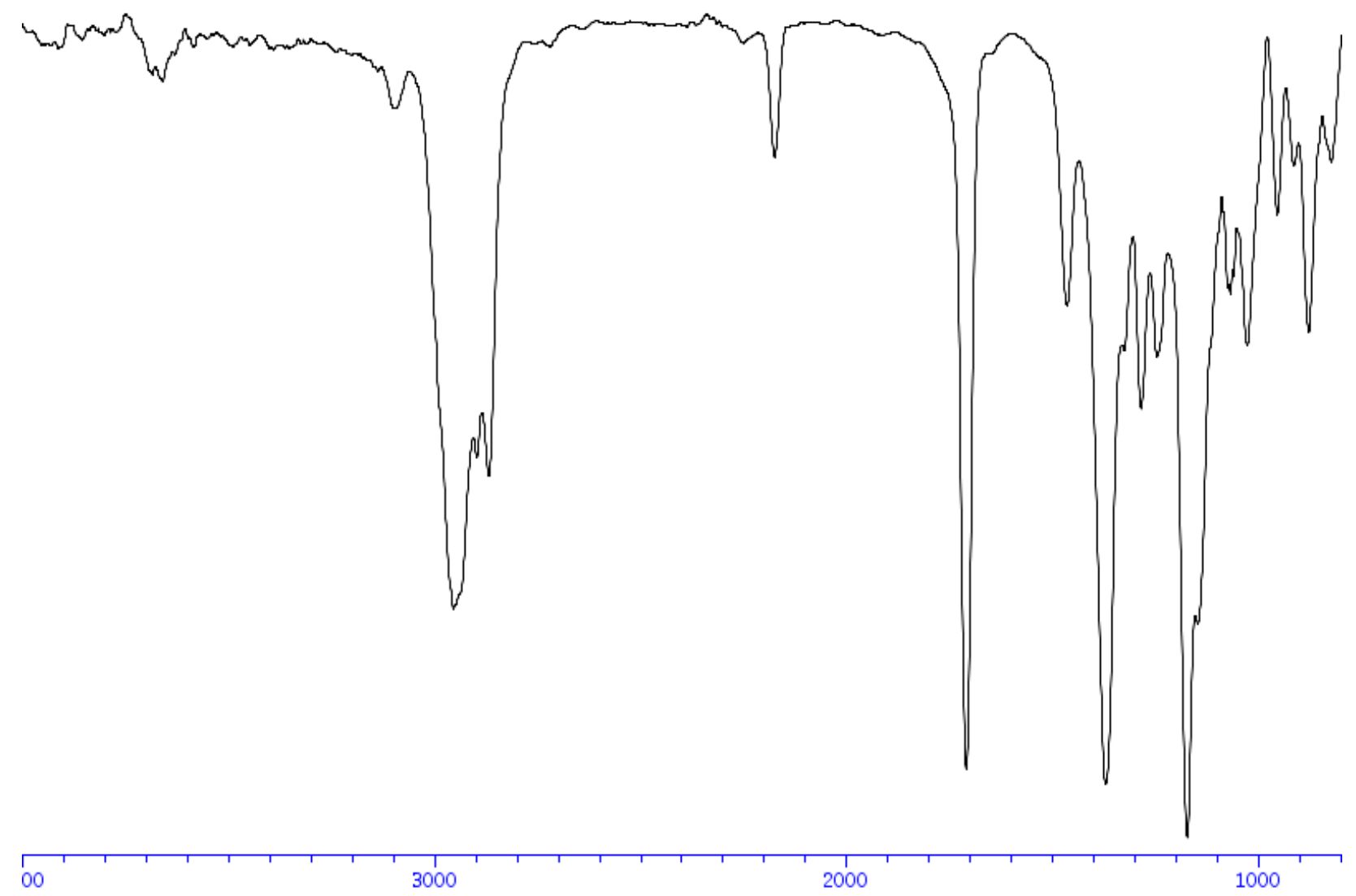



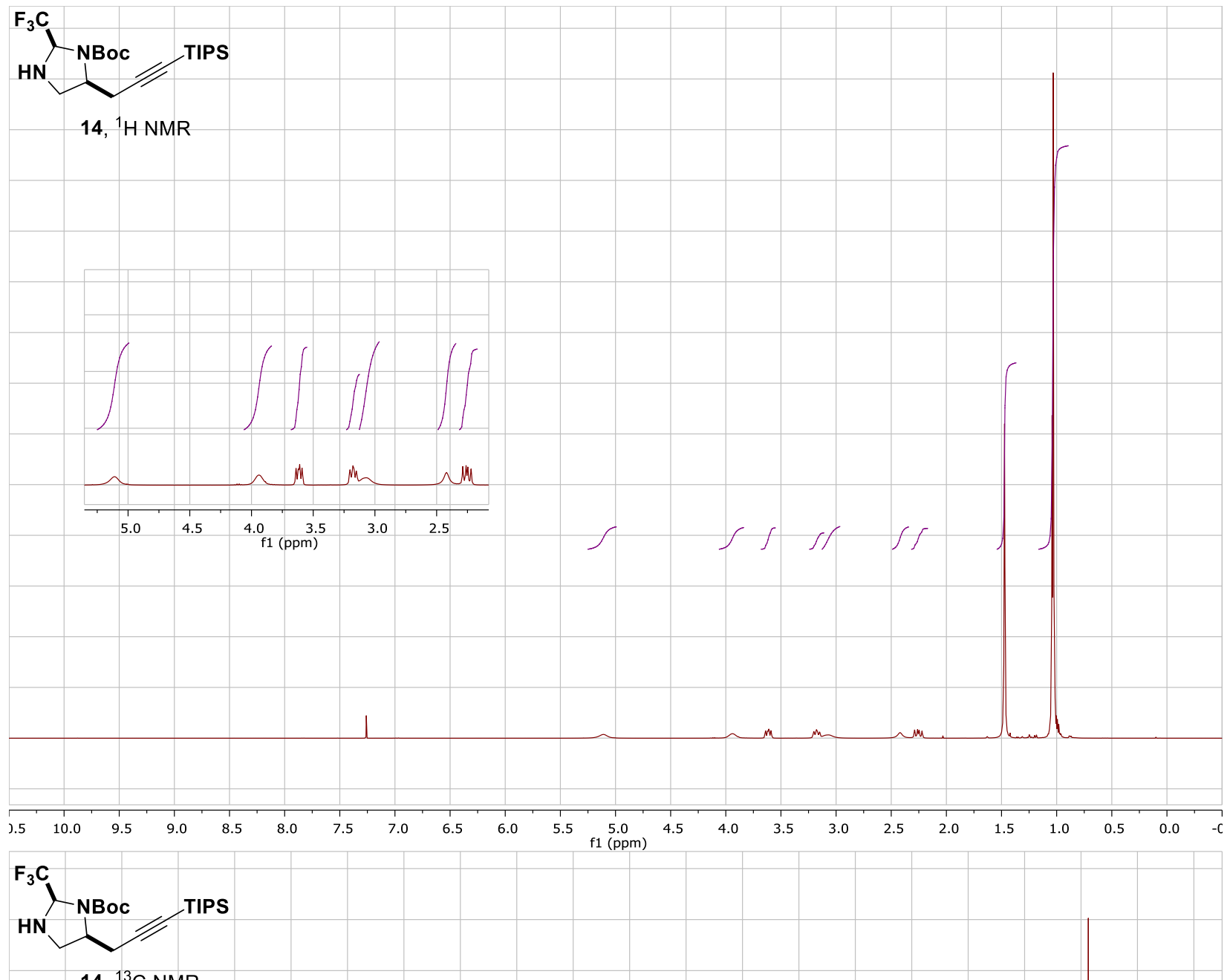

$14,{ }^{13} \mathrm{C}$ NMR

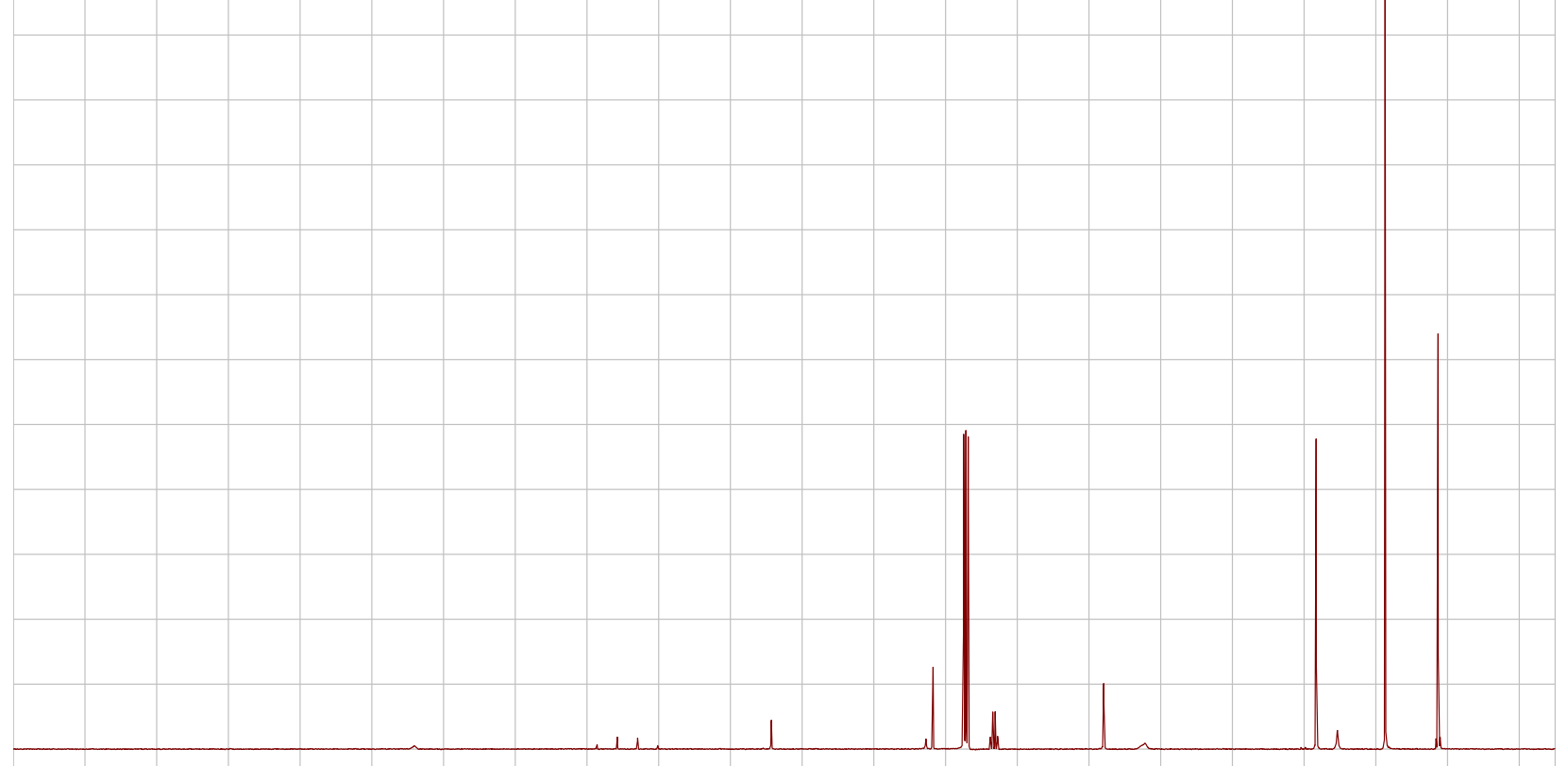

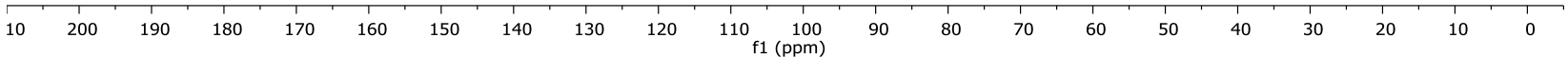




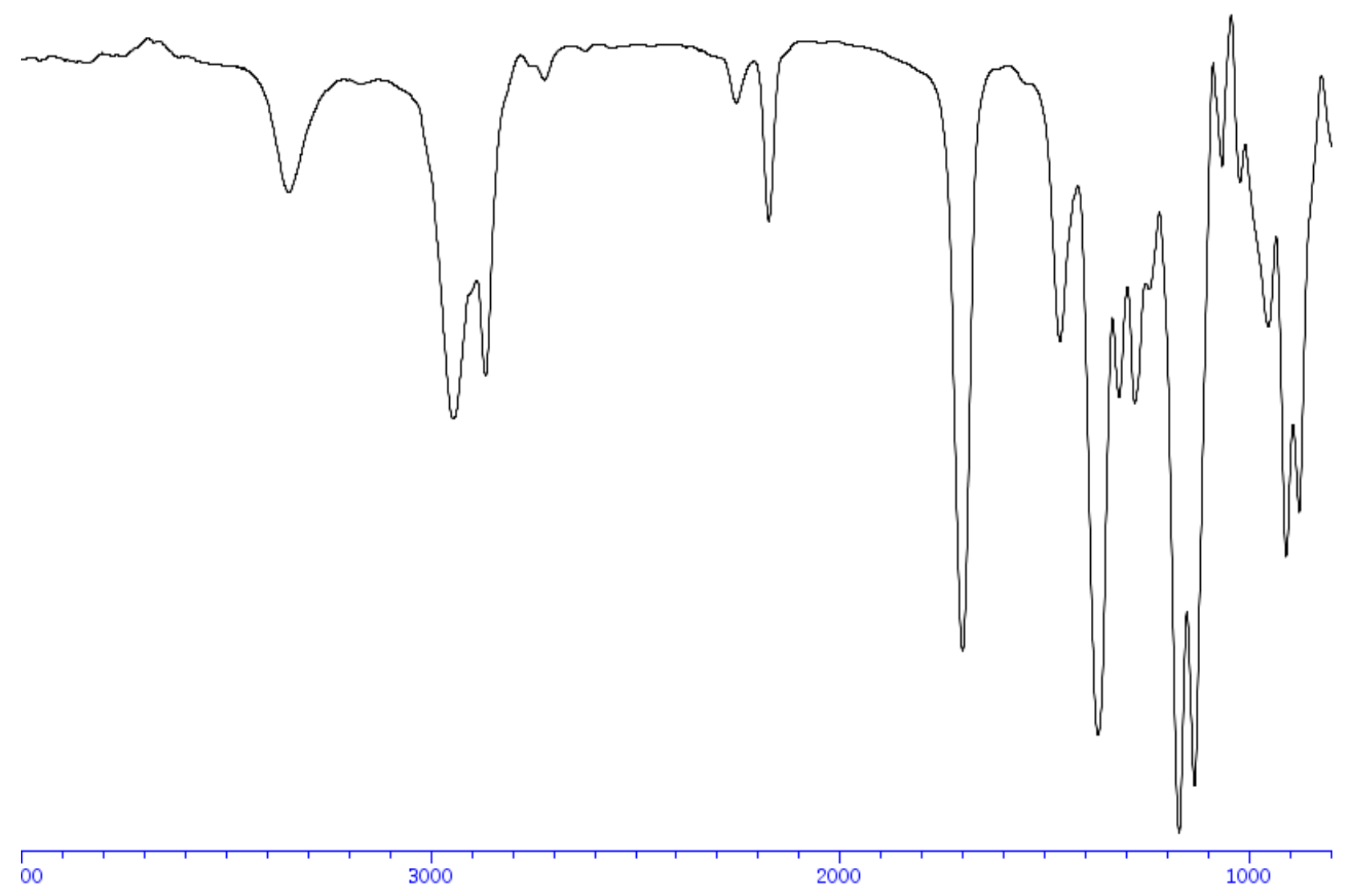



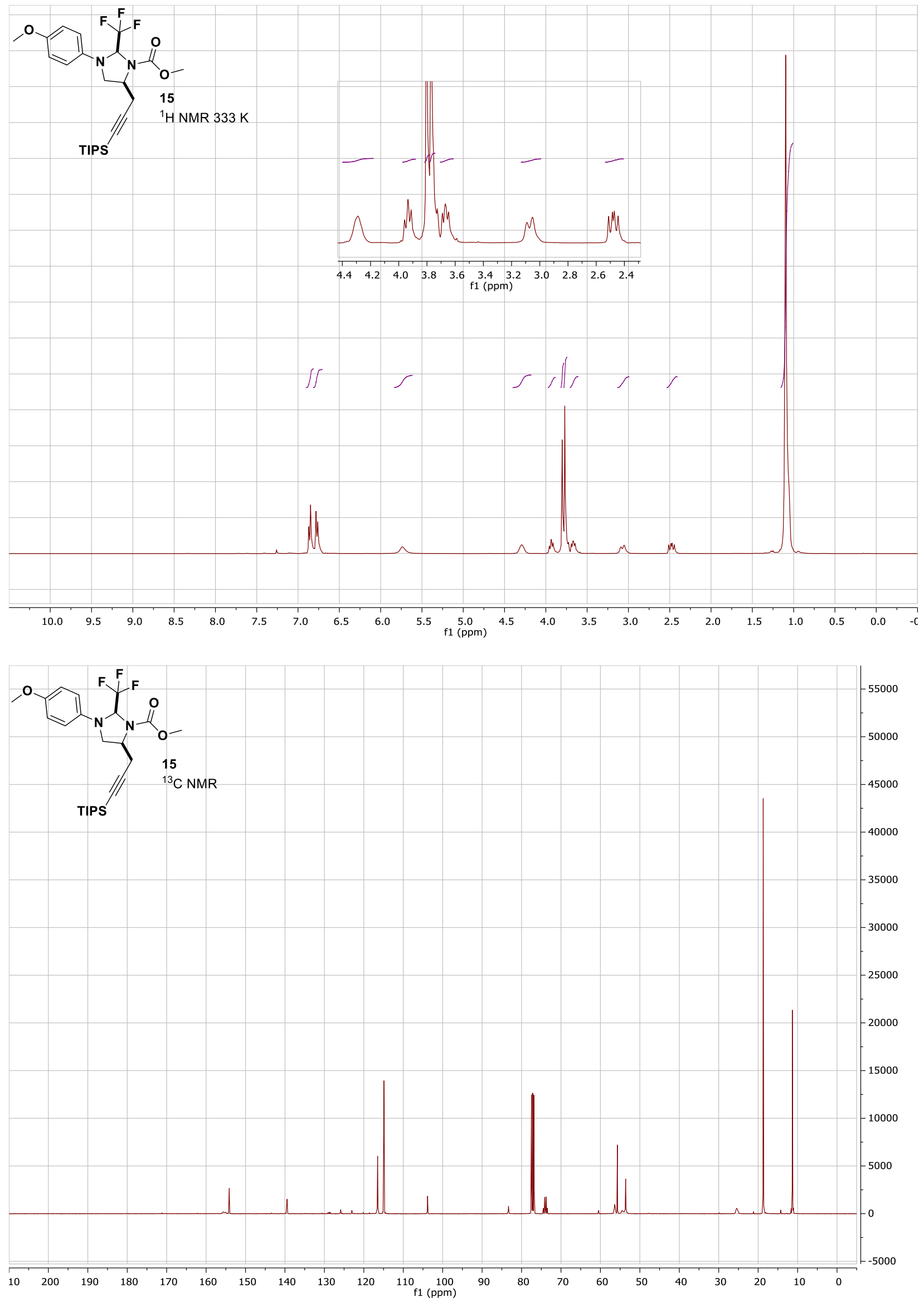


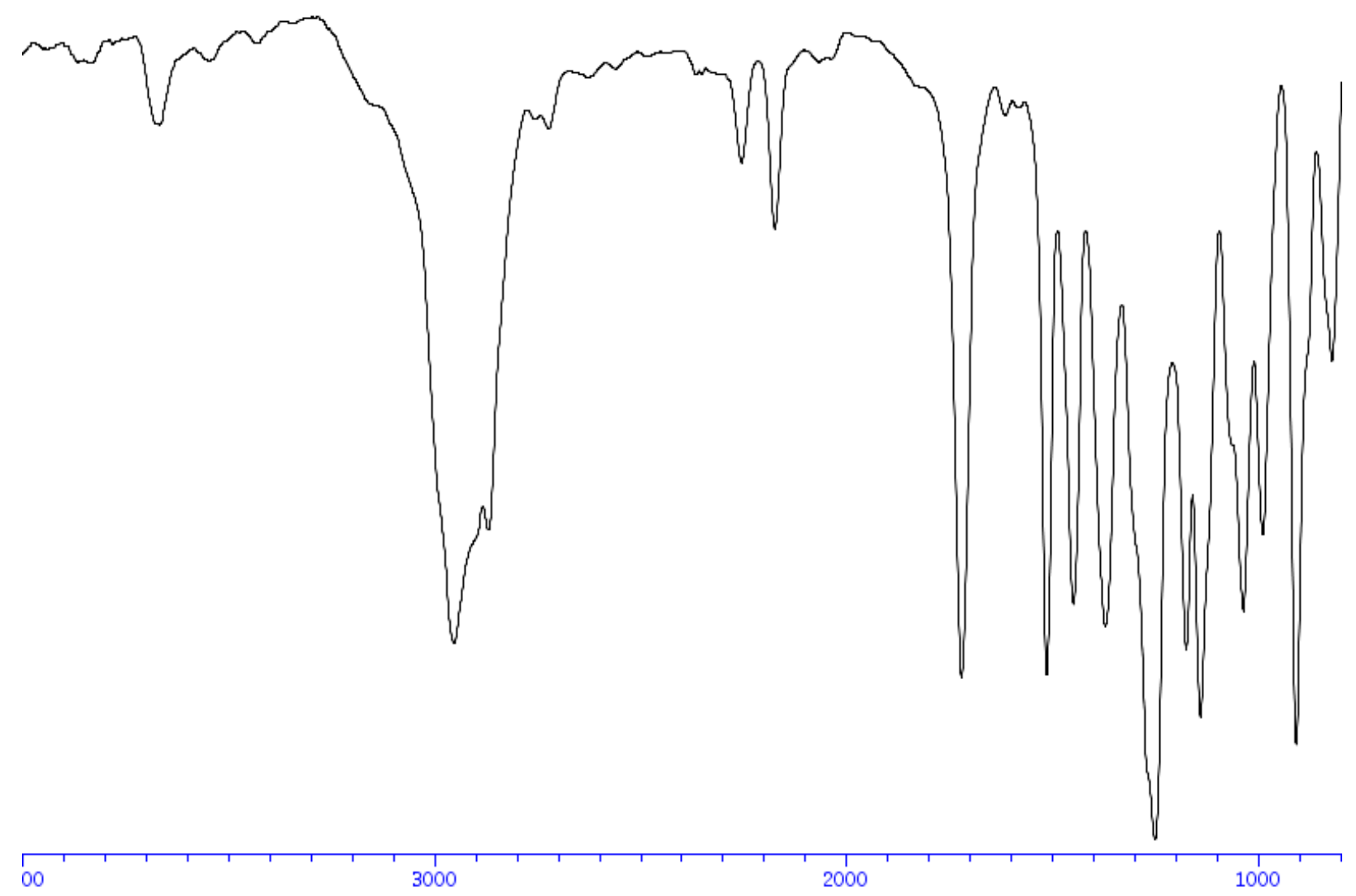



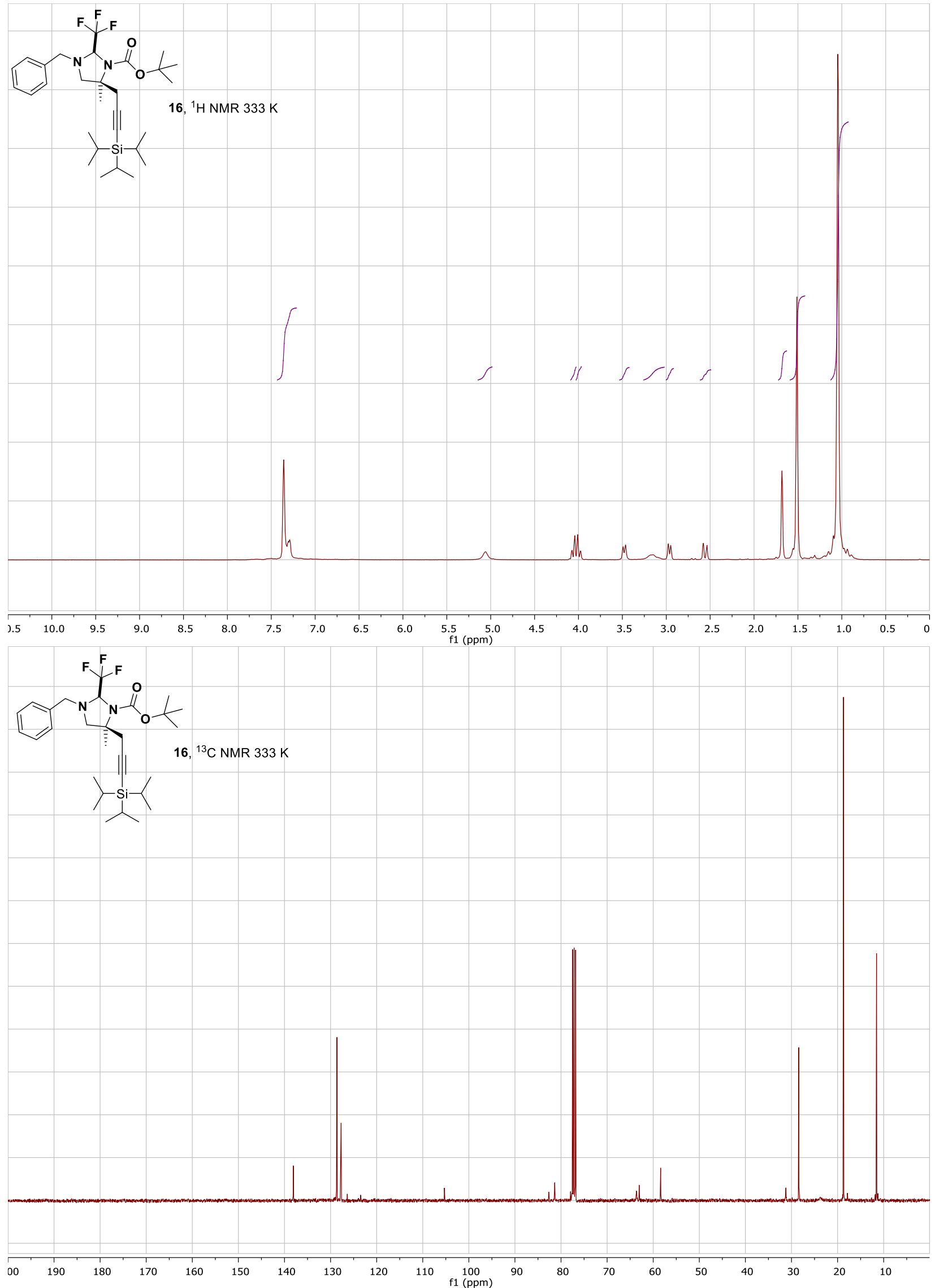

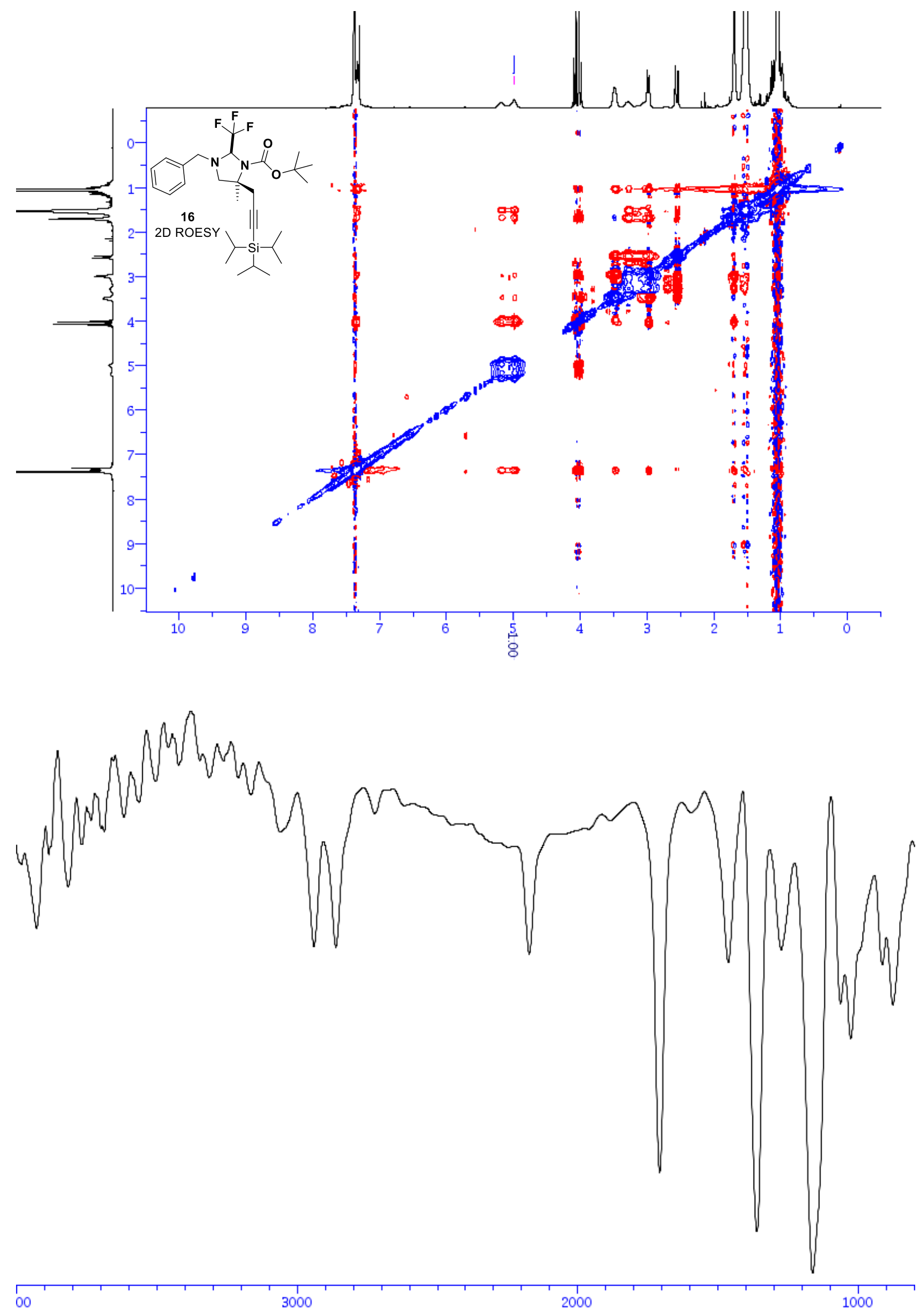


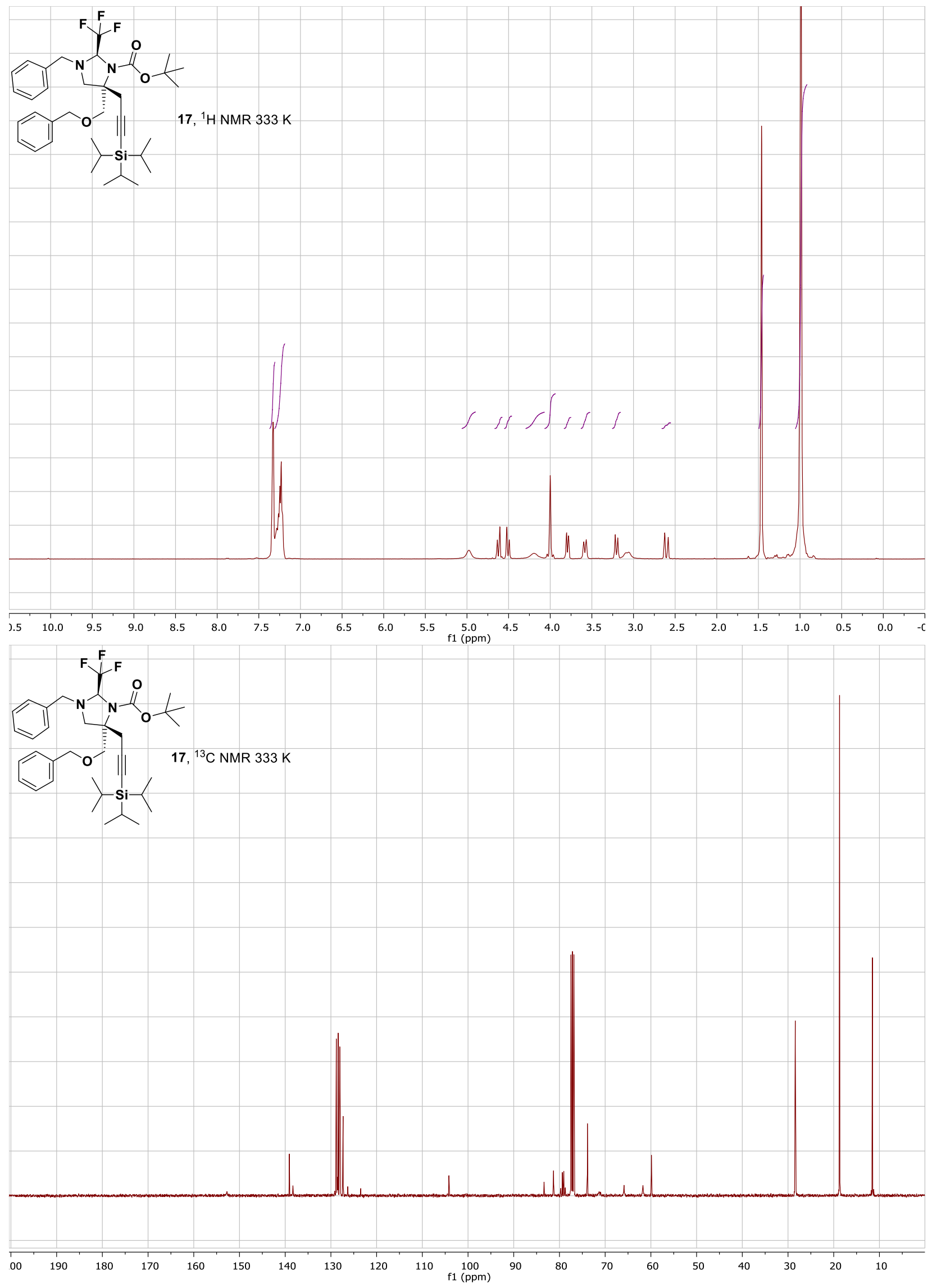




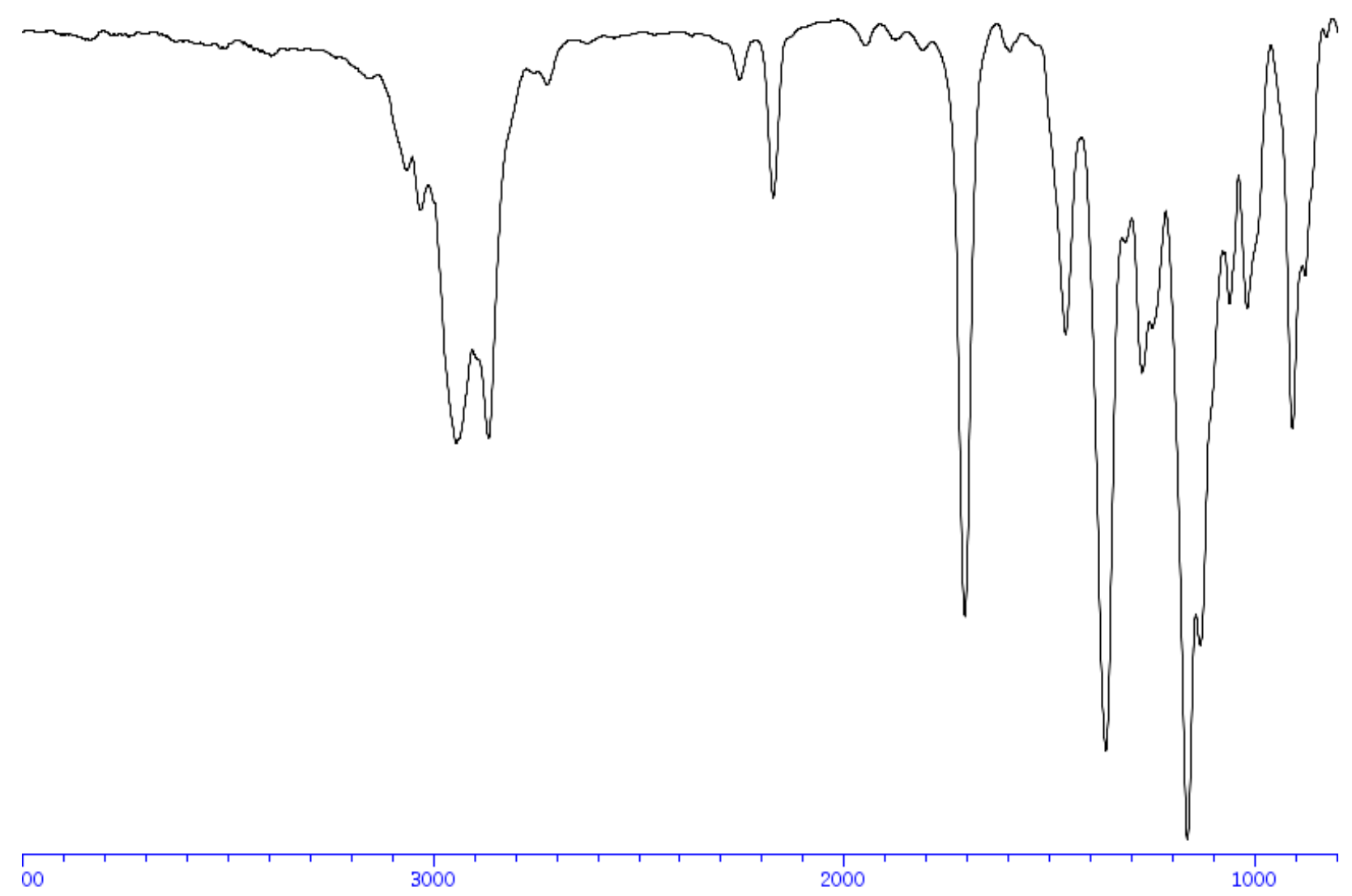



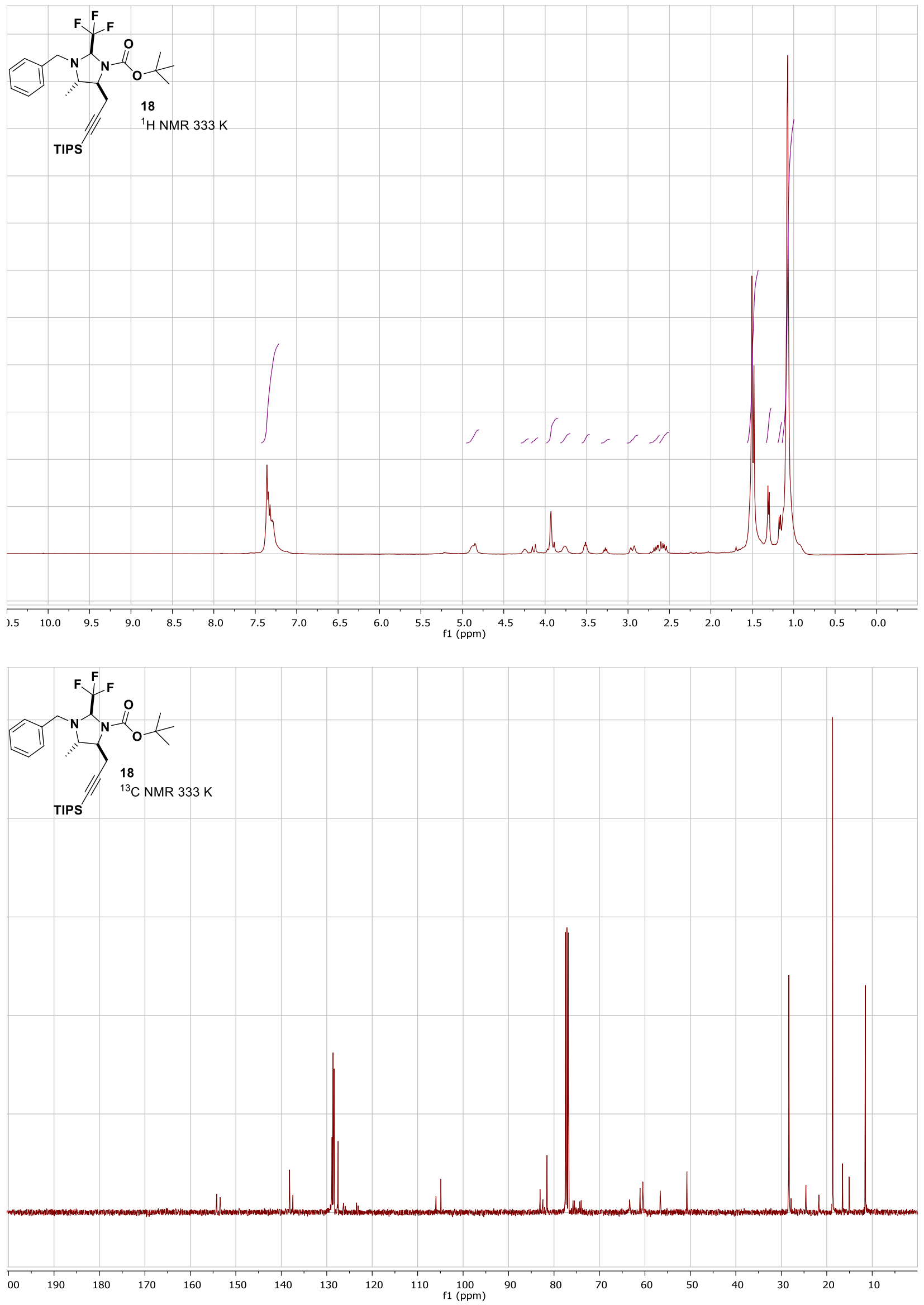

S99 


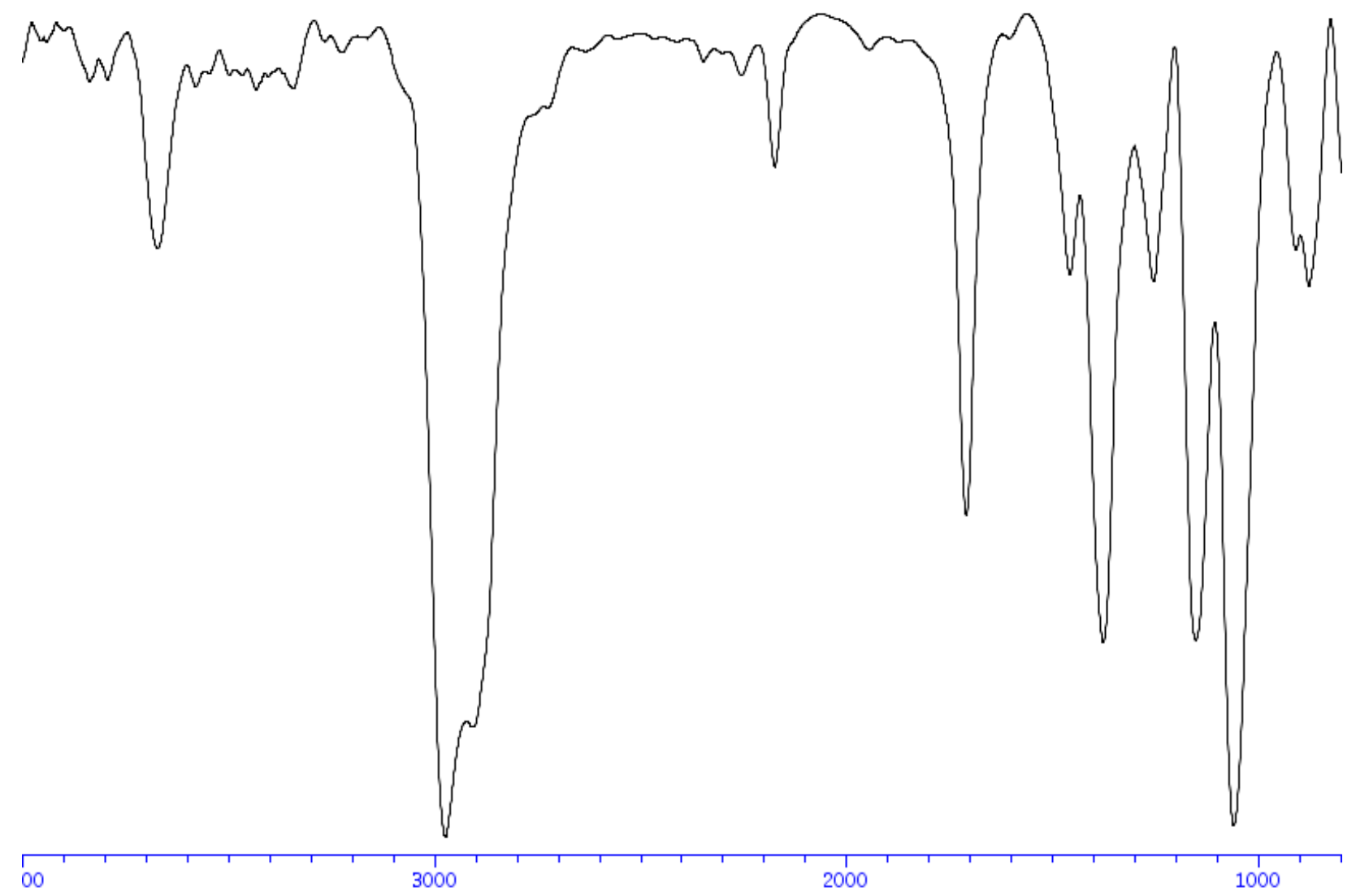




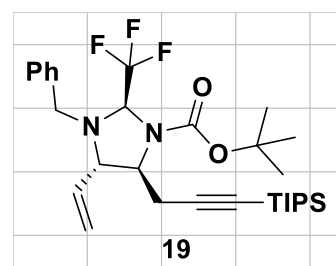

${ }^{1} \mathrm{H} \mathrm{NMR}$ in $\mathrm{CD}_{3} \mathrm{CN}$
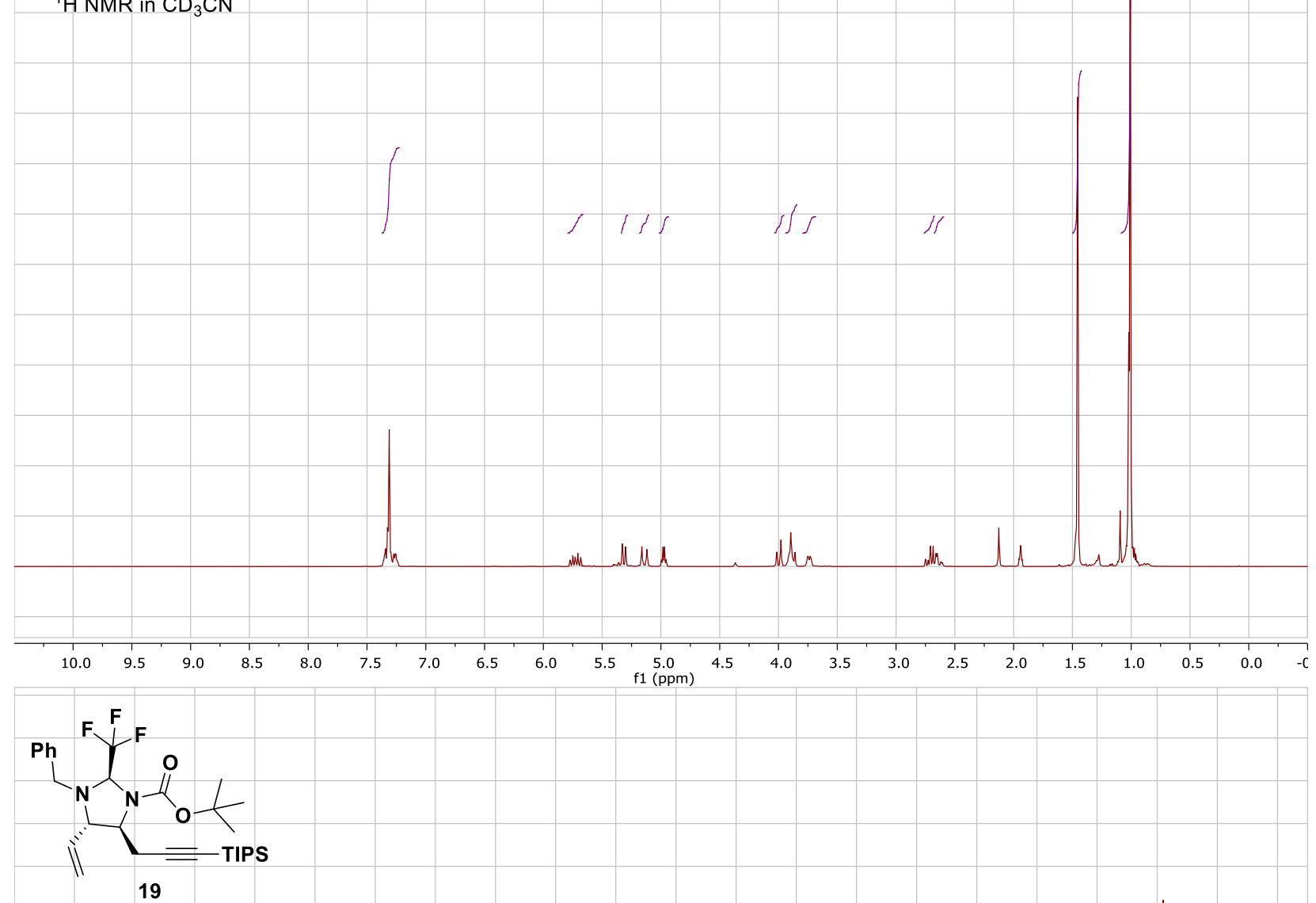

${ }^{13} \mathrm{C}$ NMR in $\mathrm{CD}_{3} \mathrm{CN}$

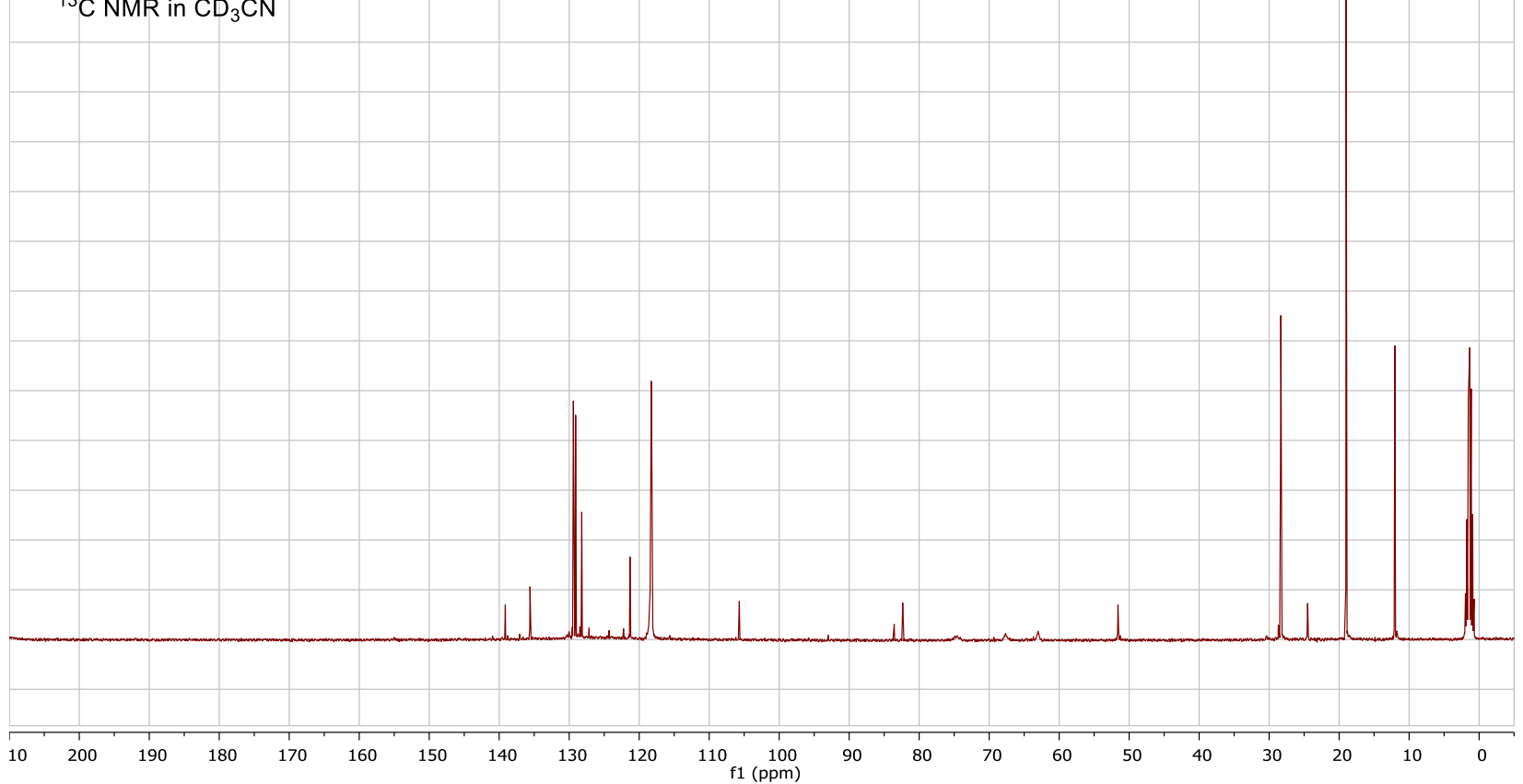



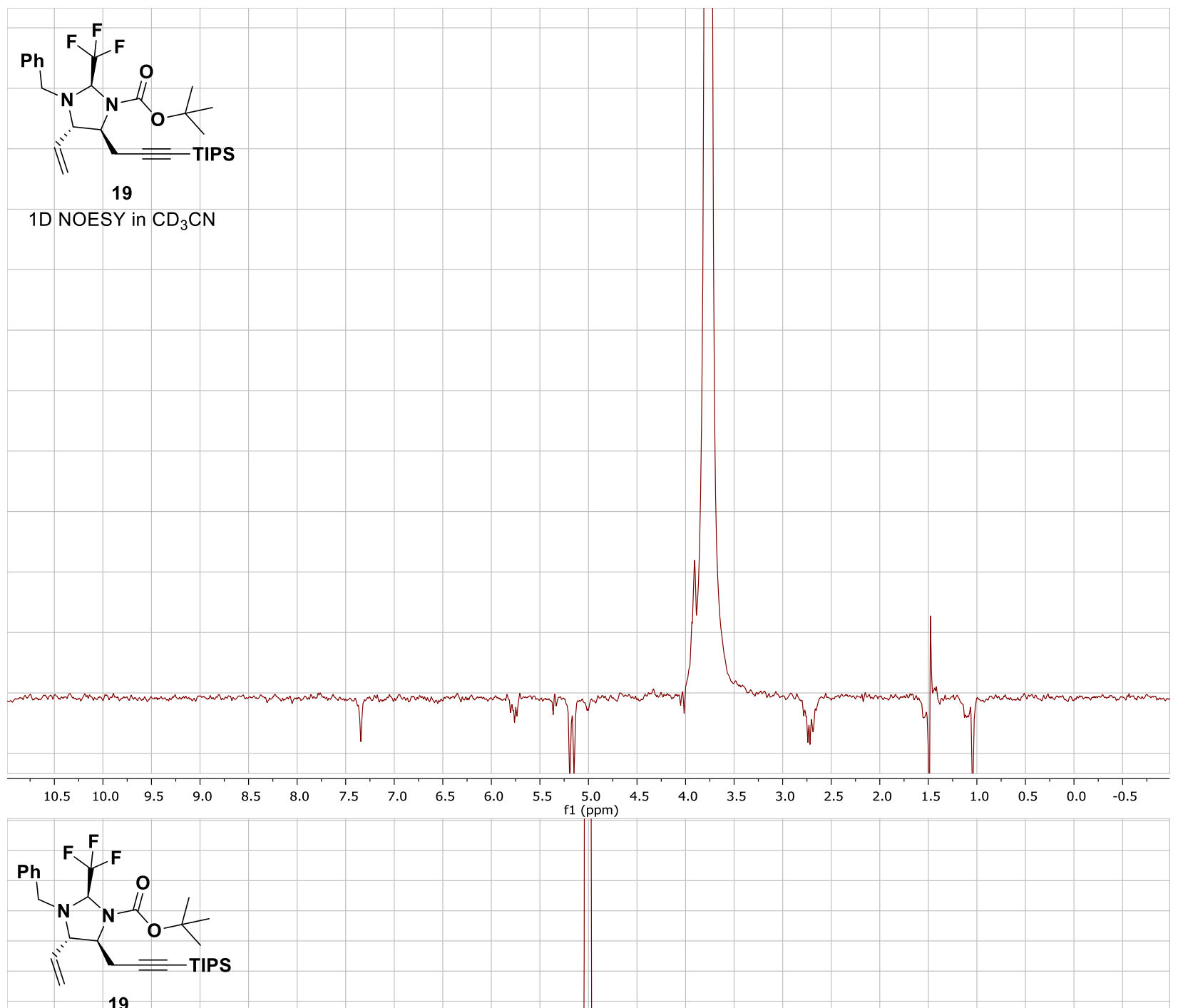

1D NOESY in $\mathrm{CD}_{3} \mathrm{CN}$

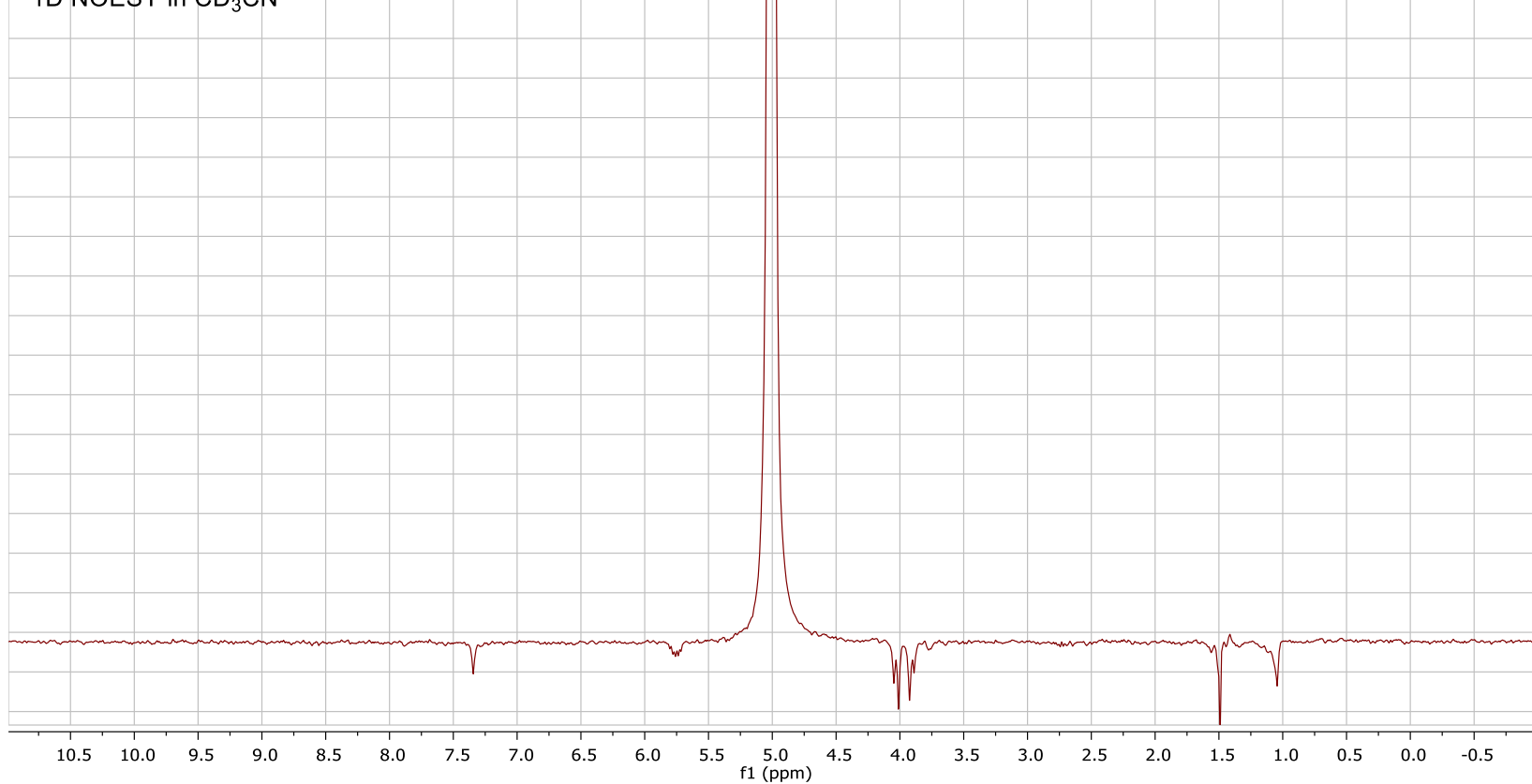




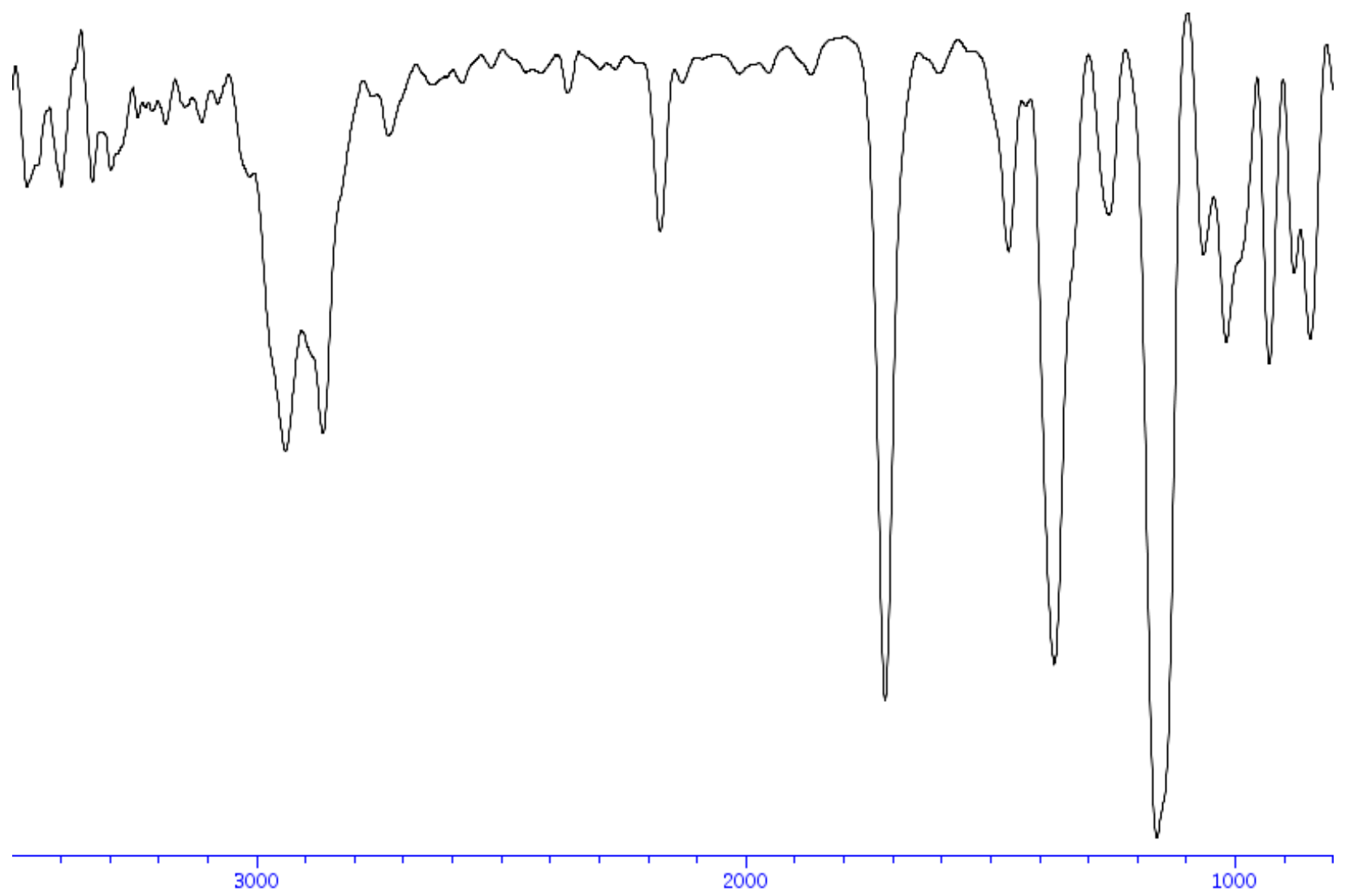




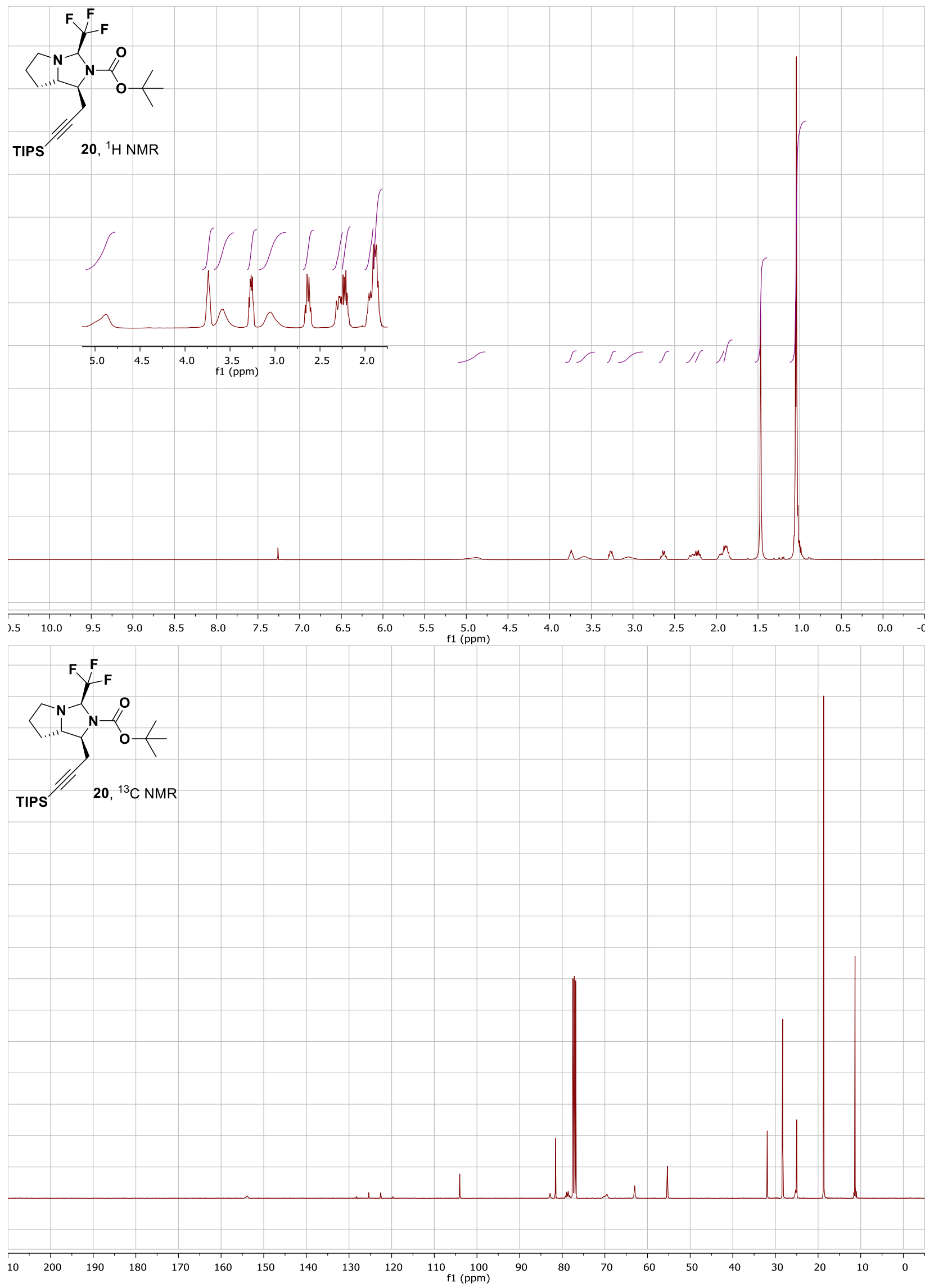




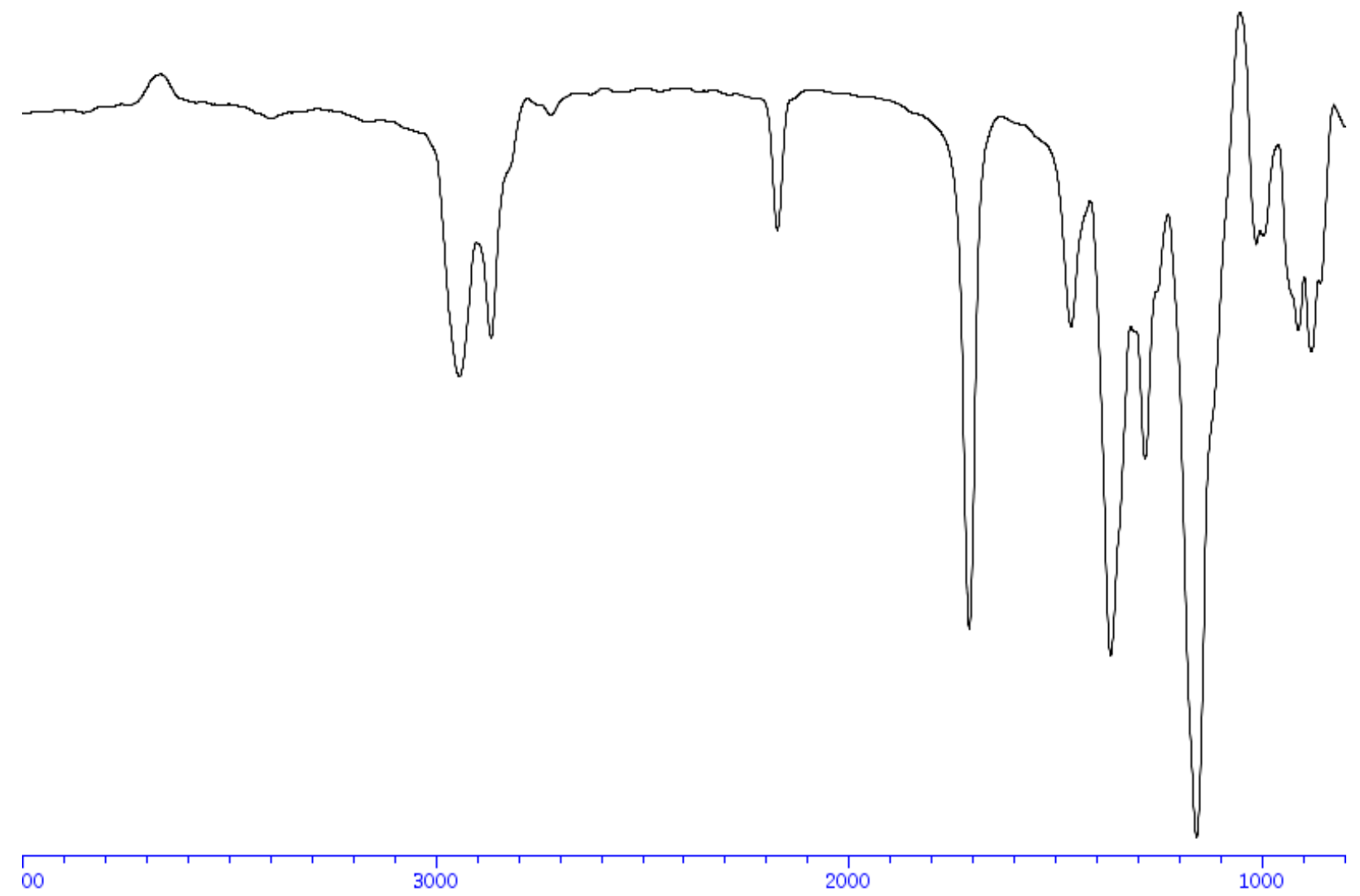




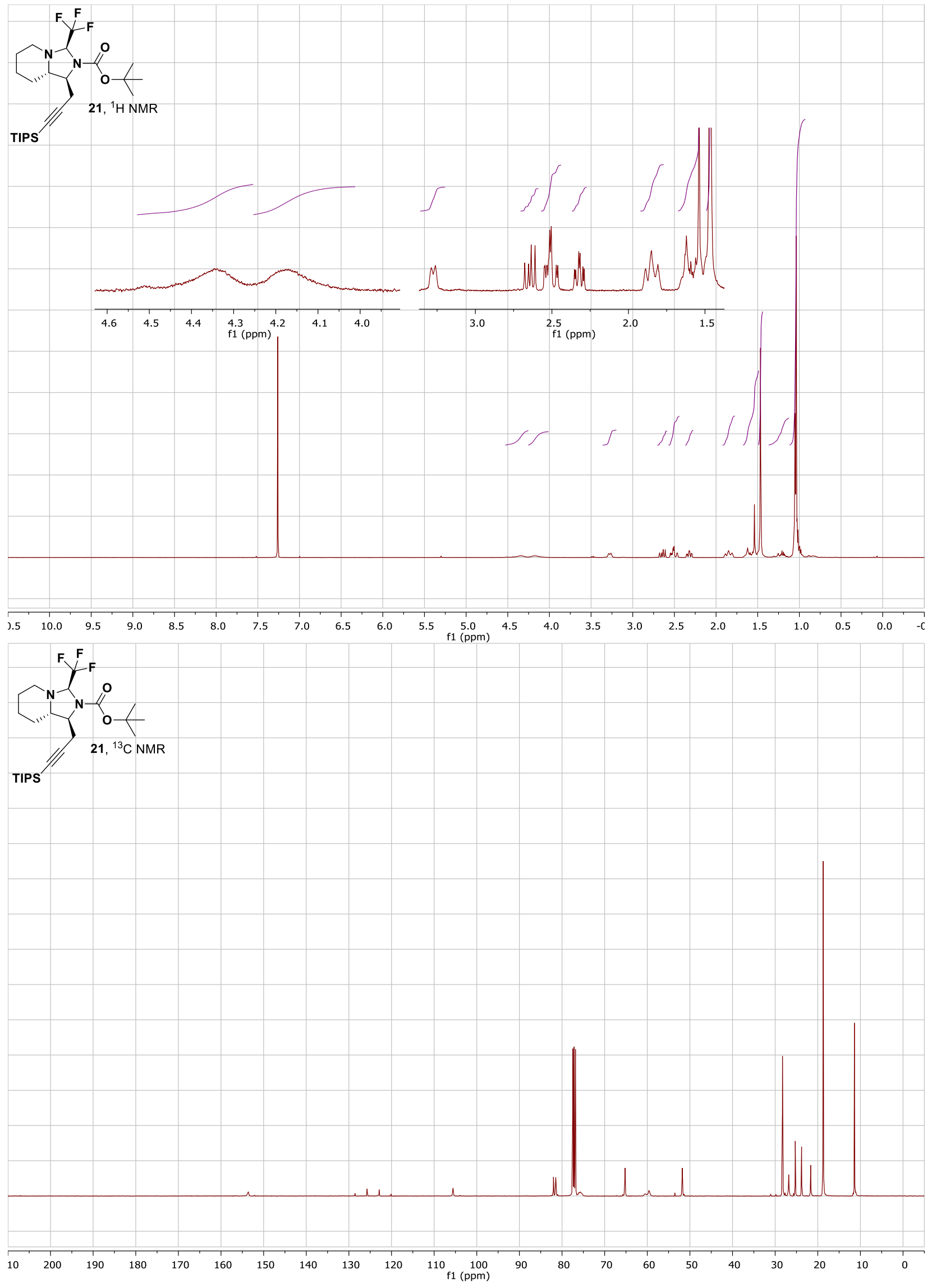




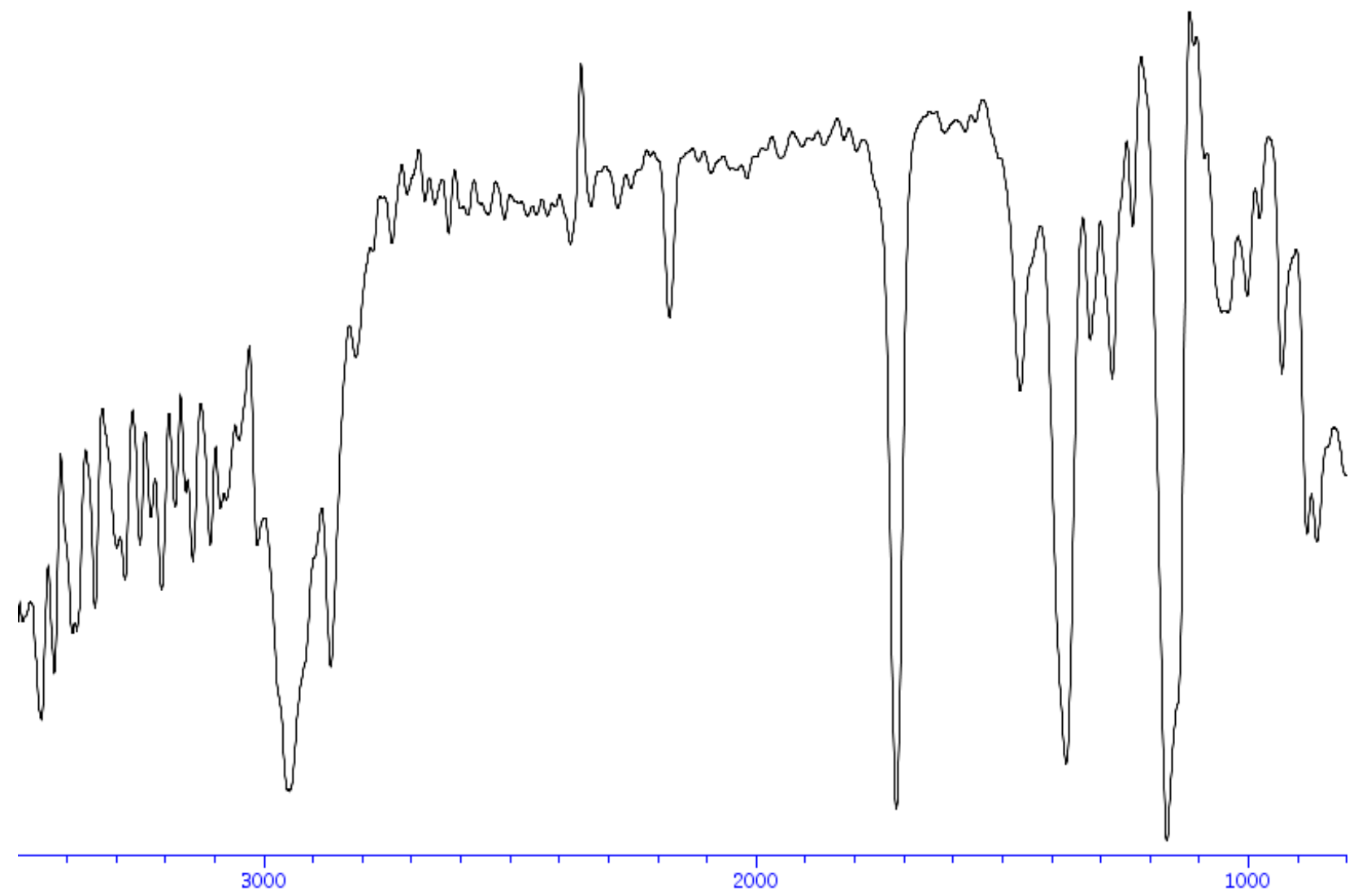

S107 

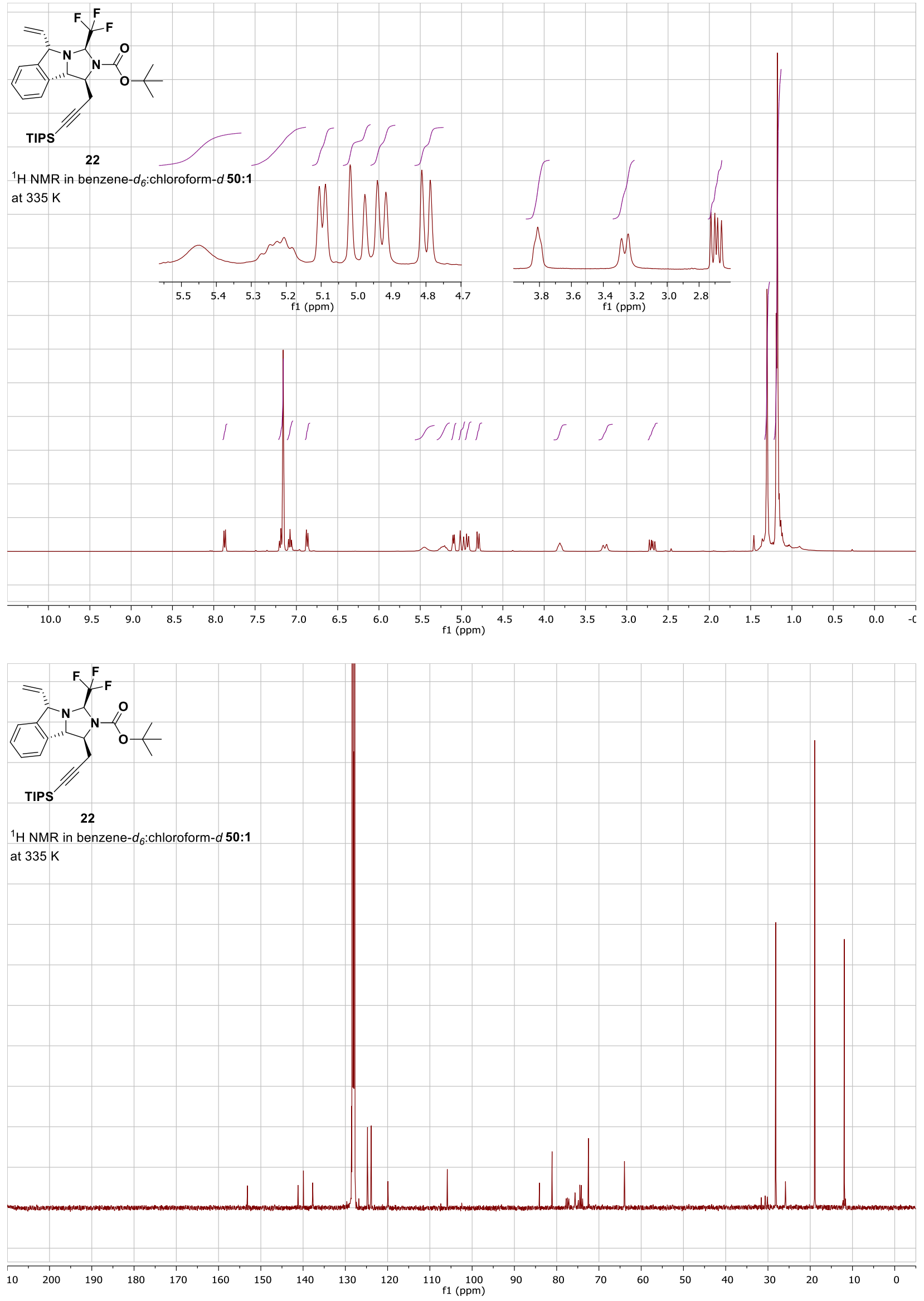

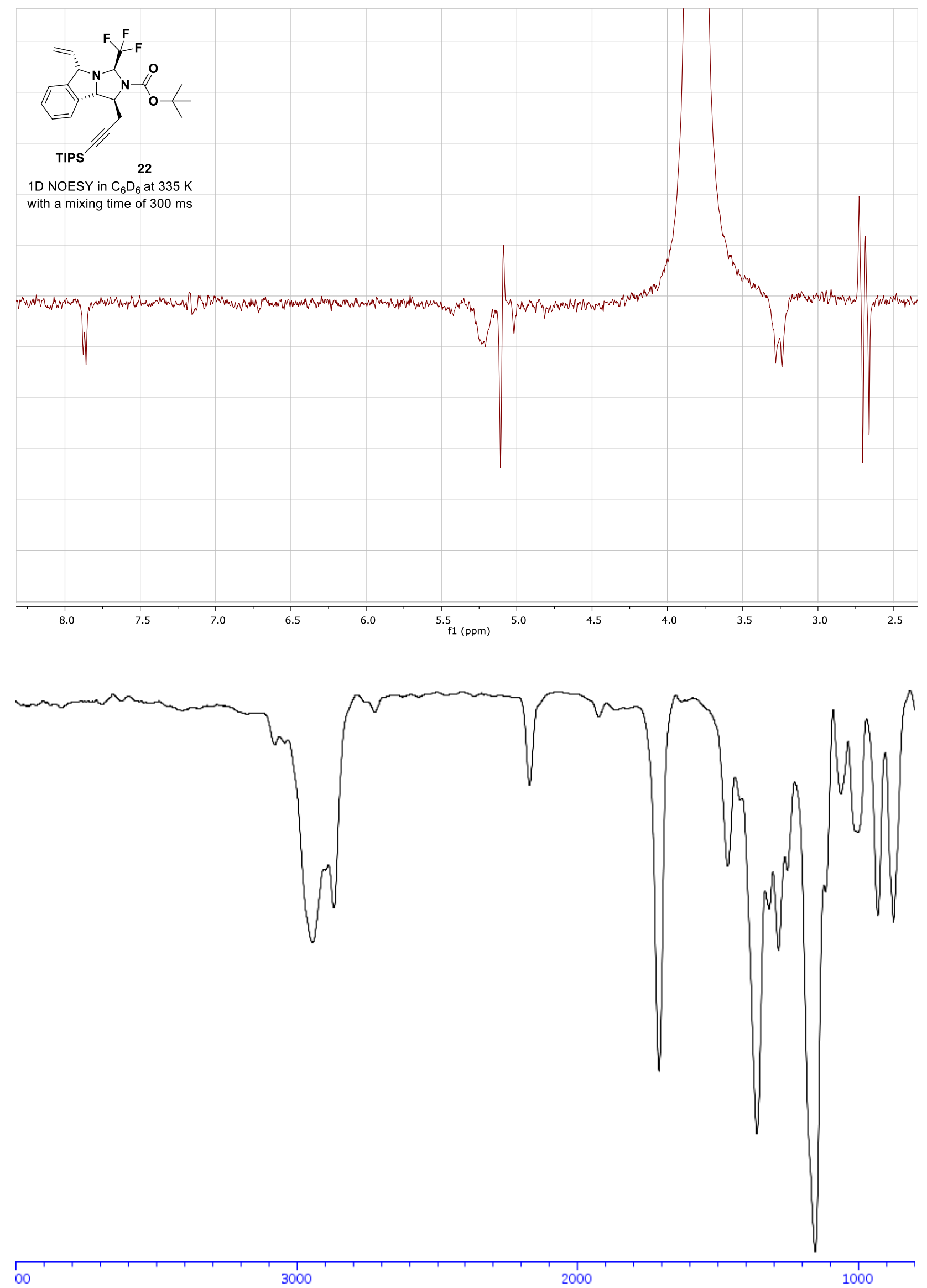

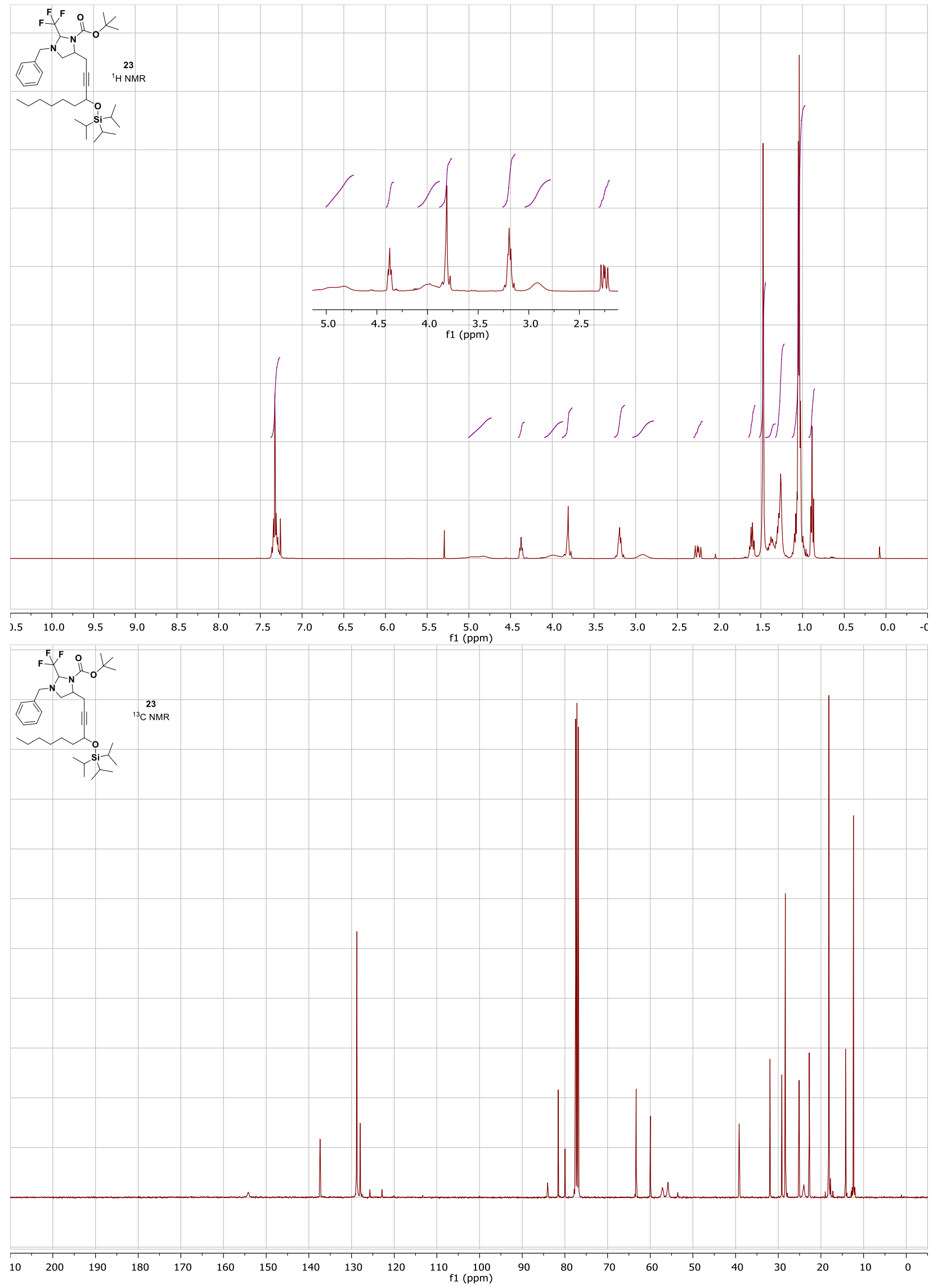


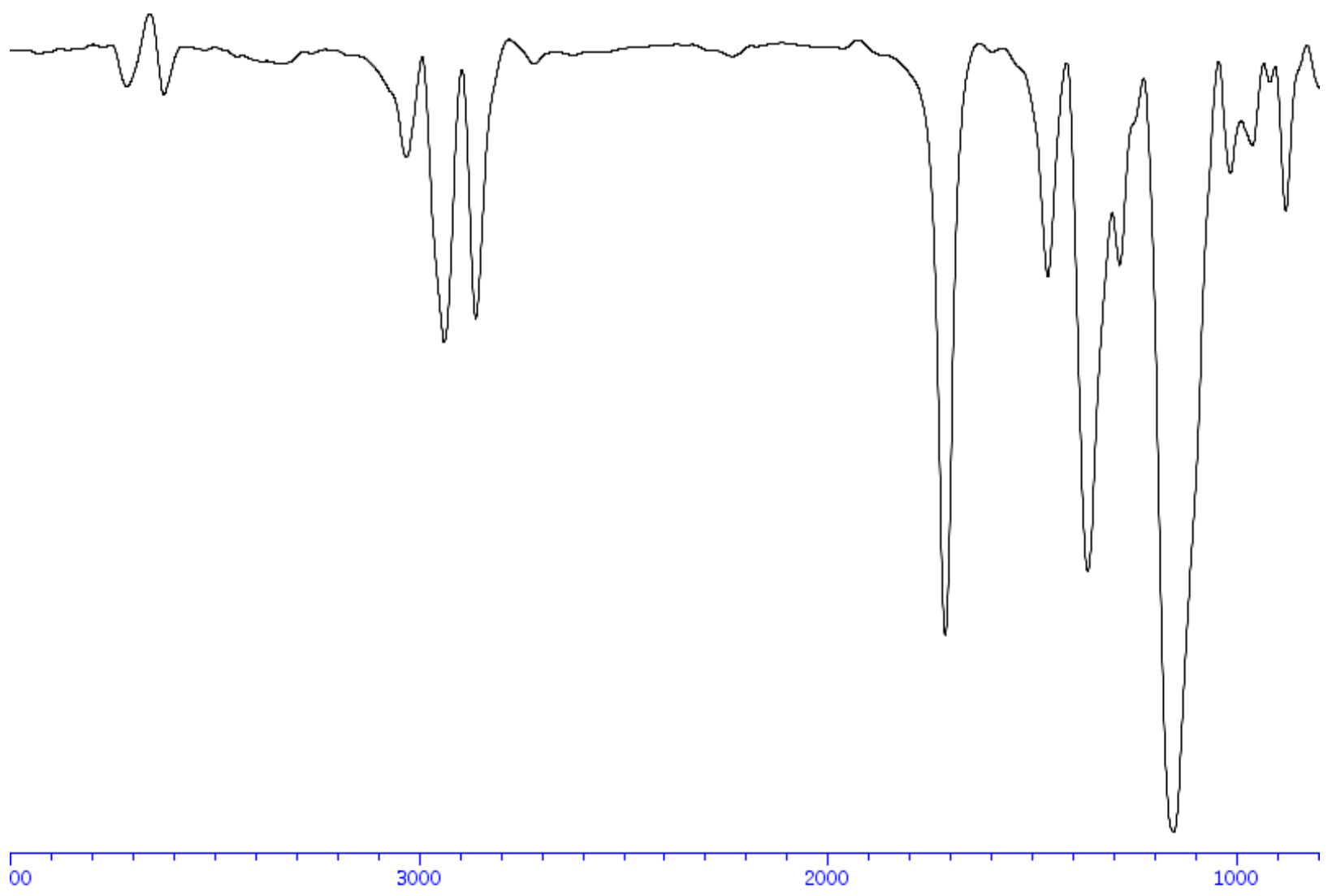




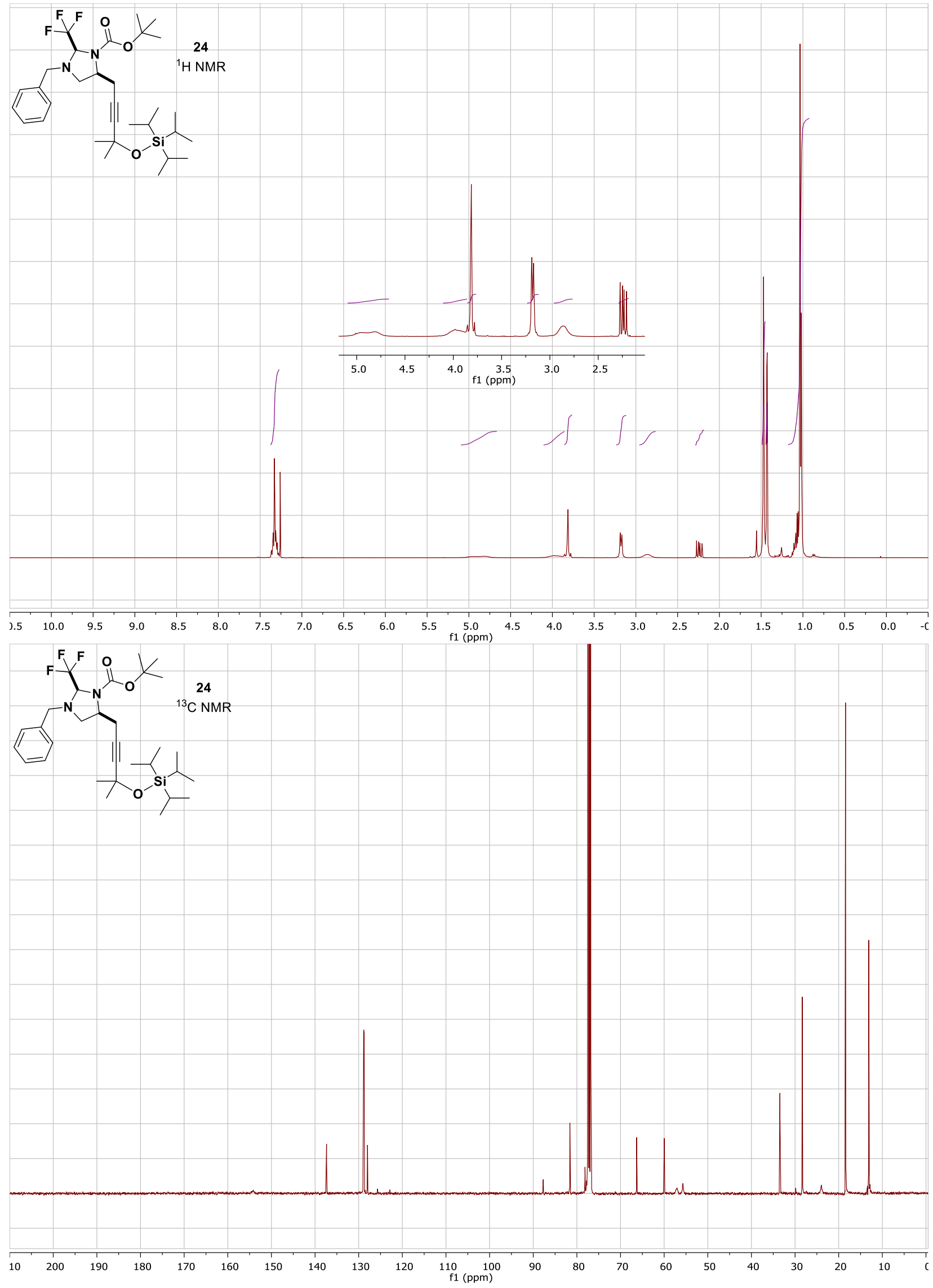




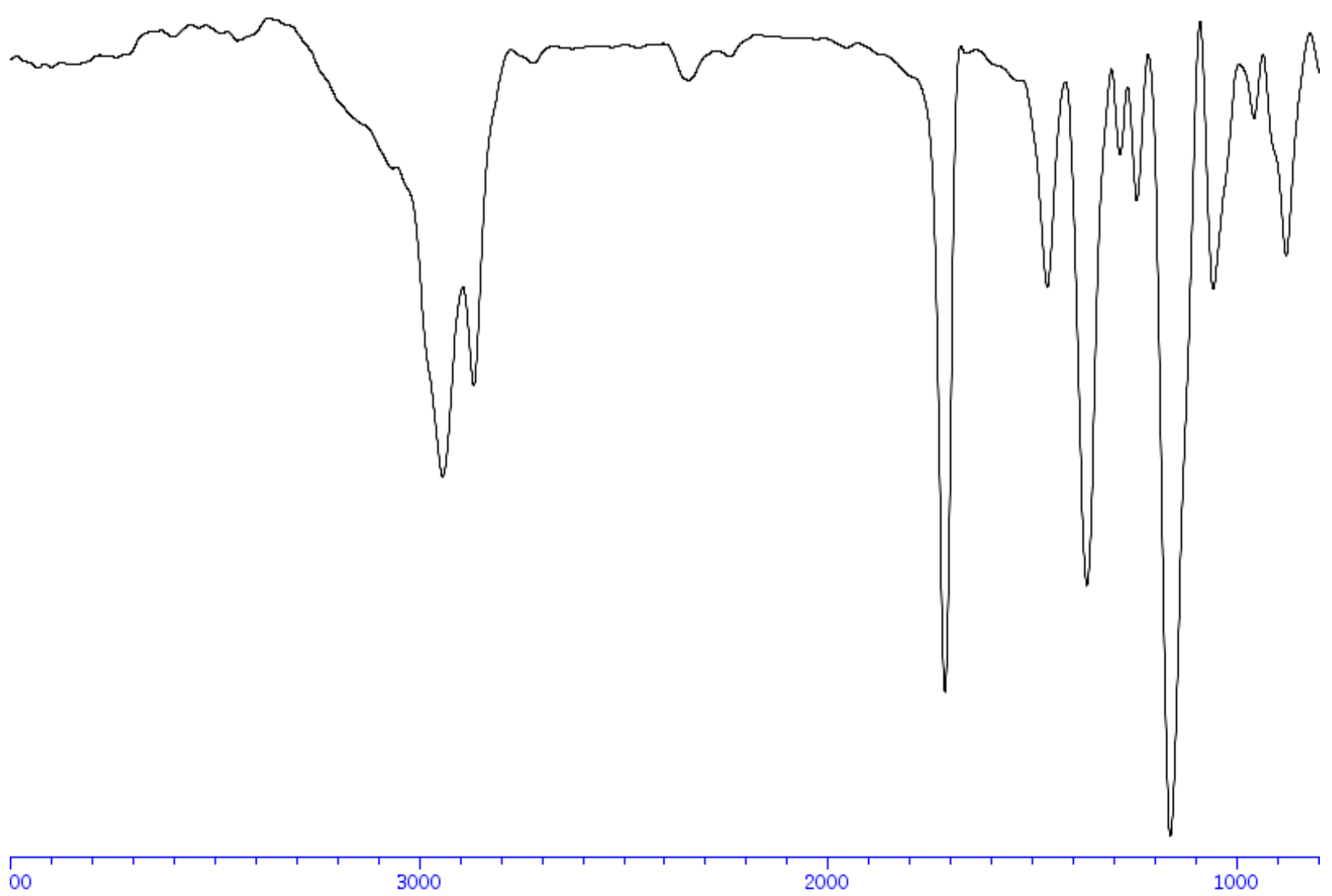



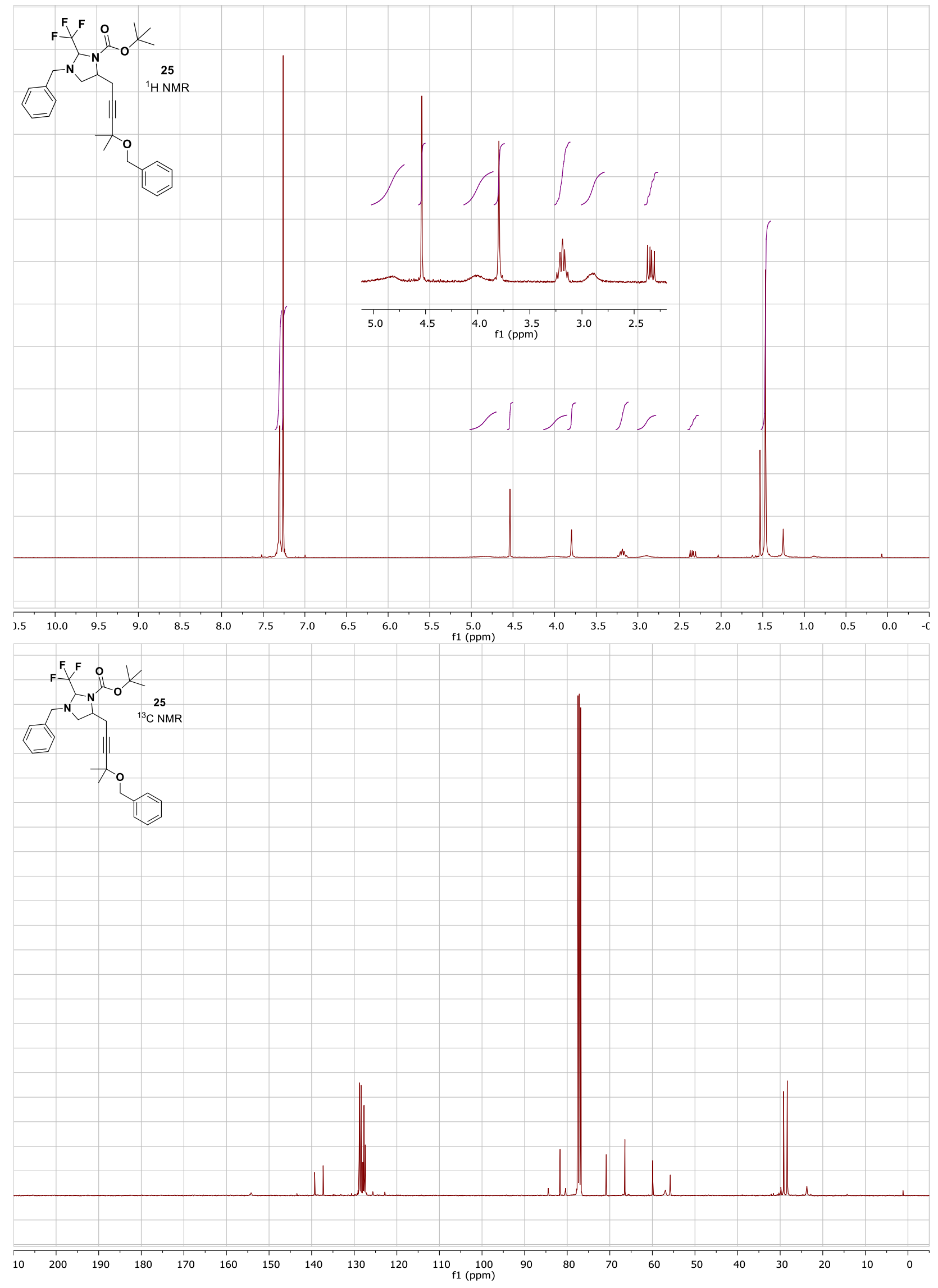

S114 


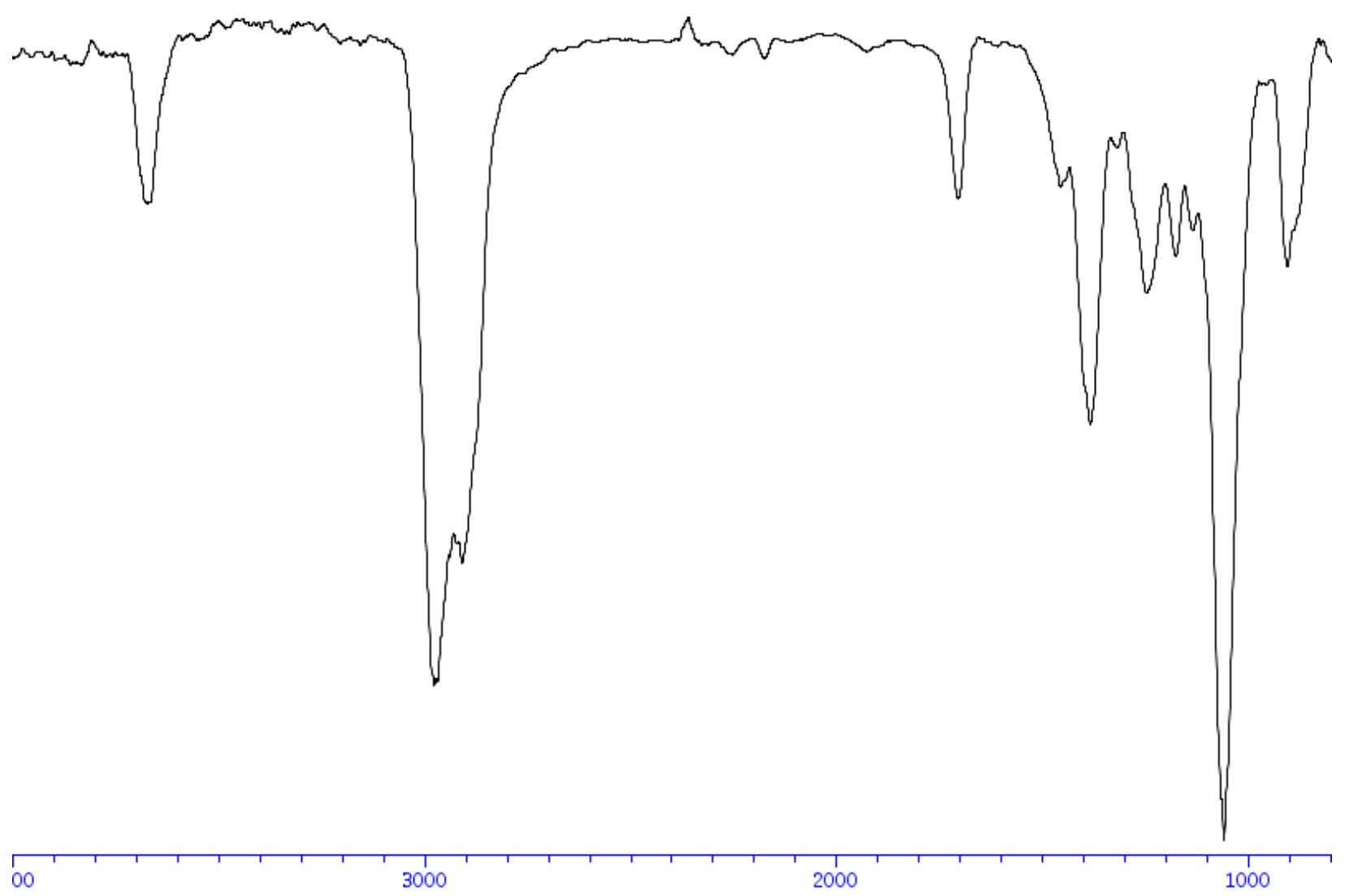



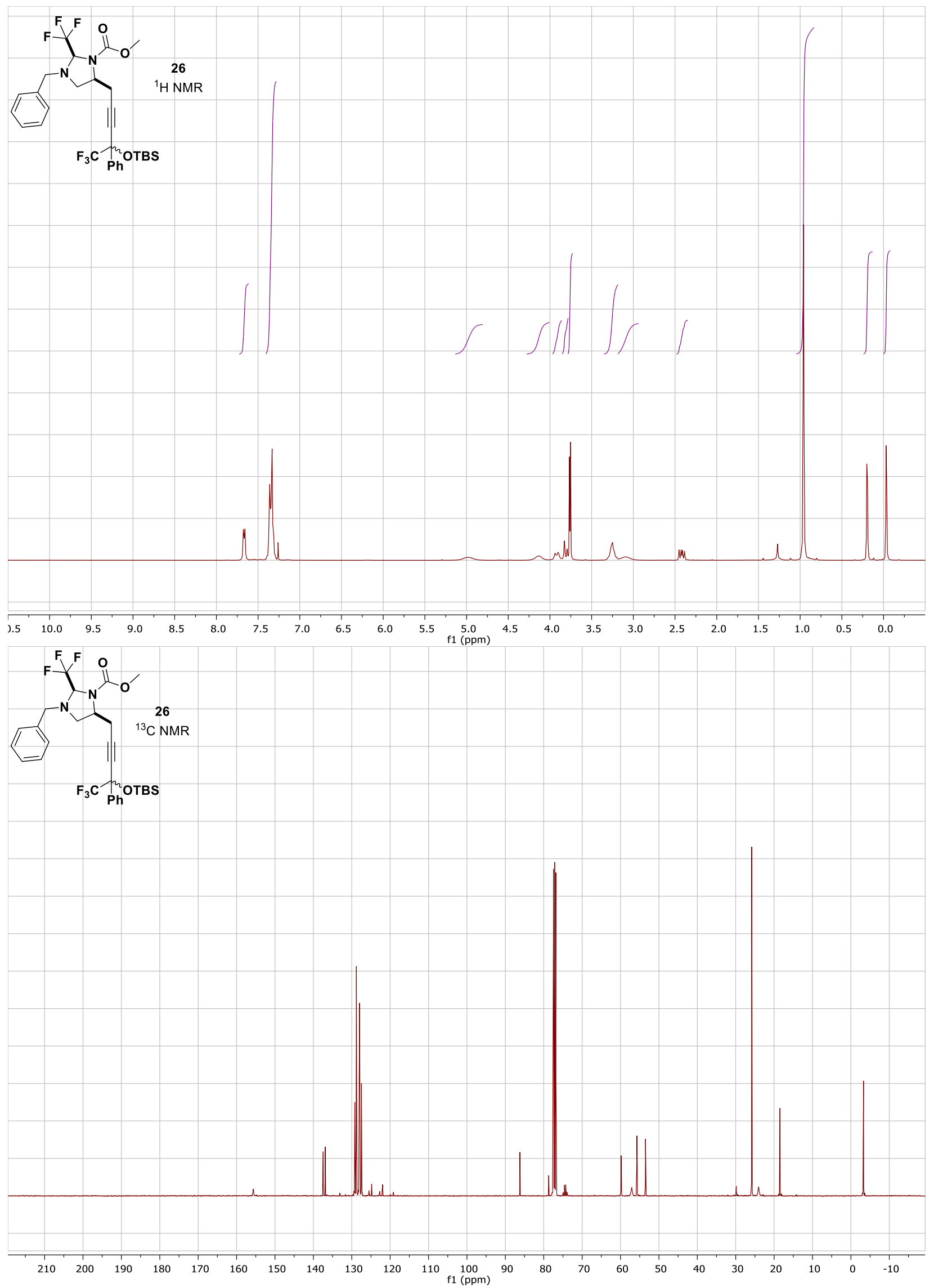


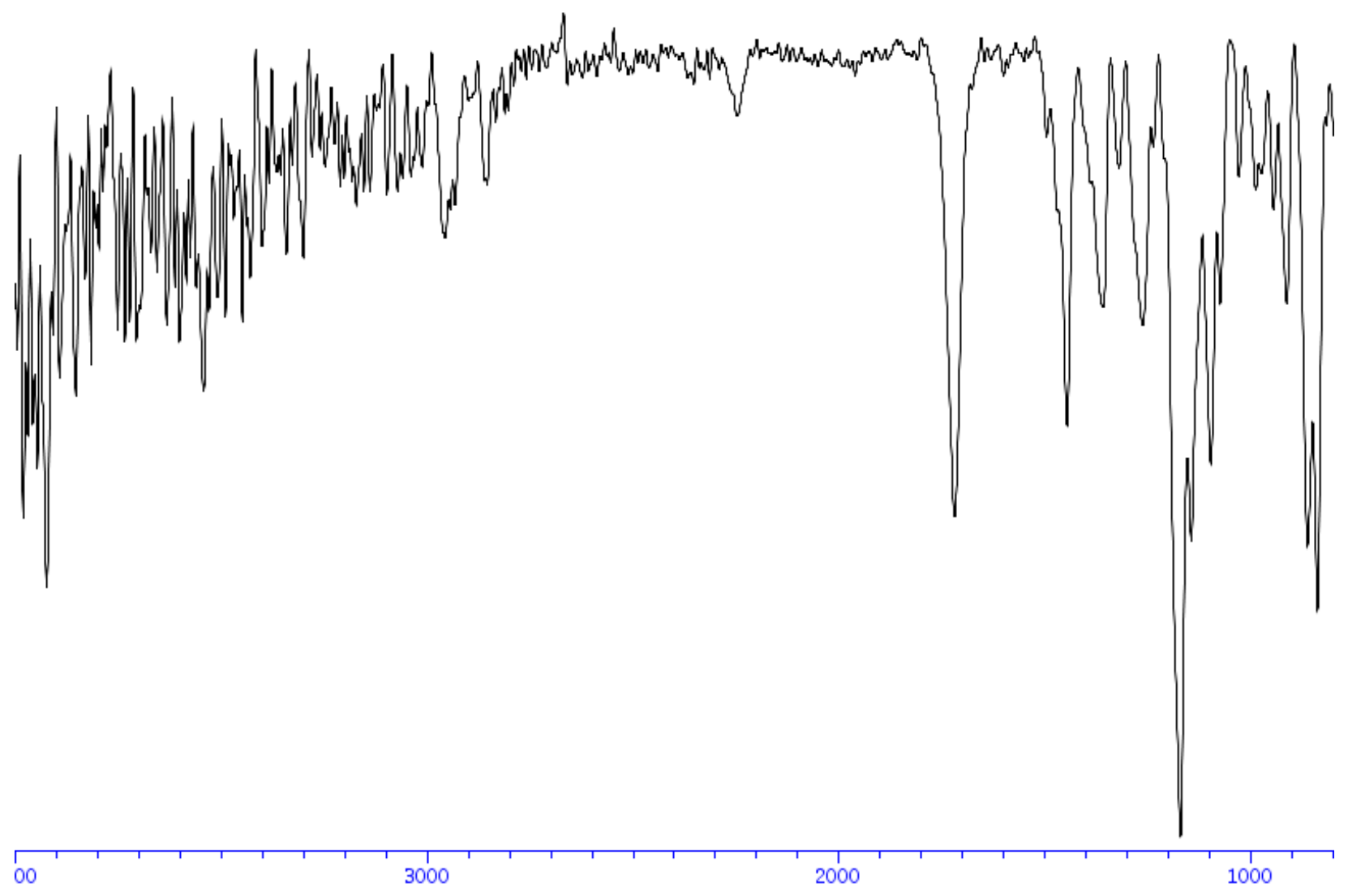




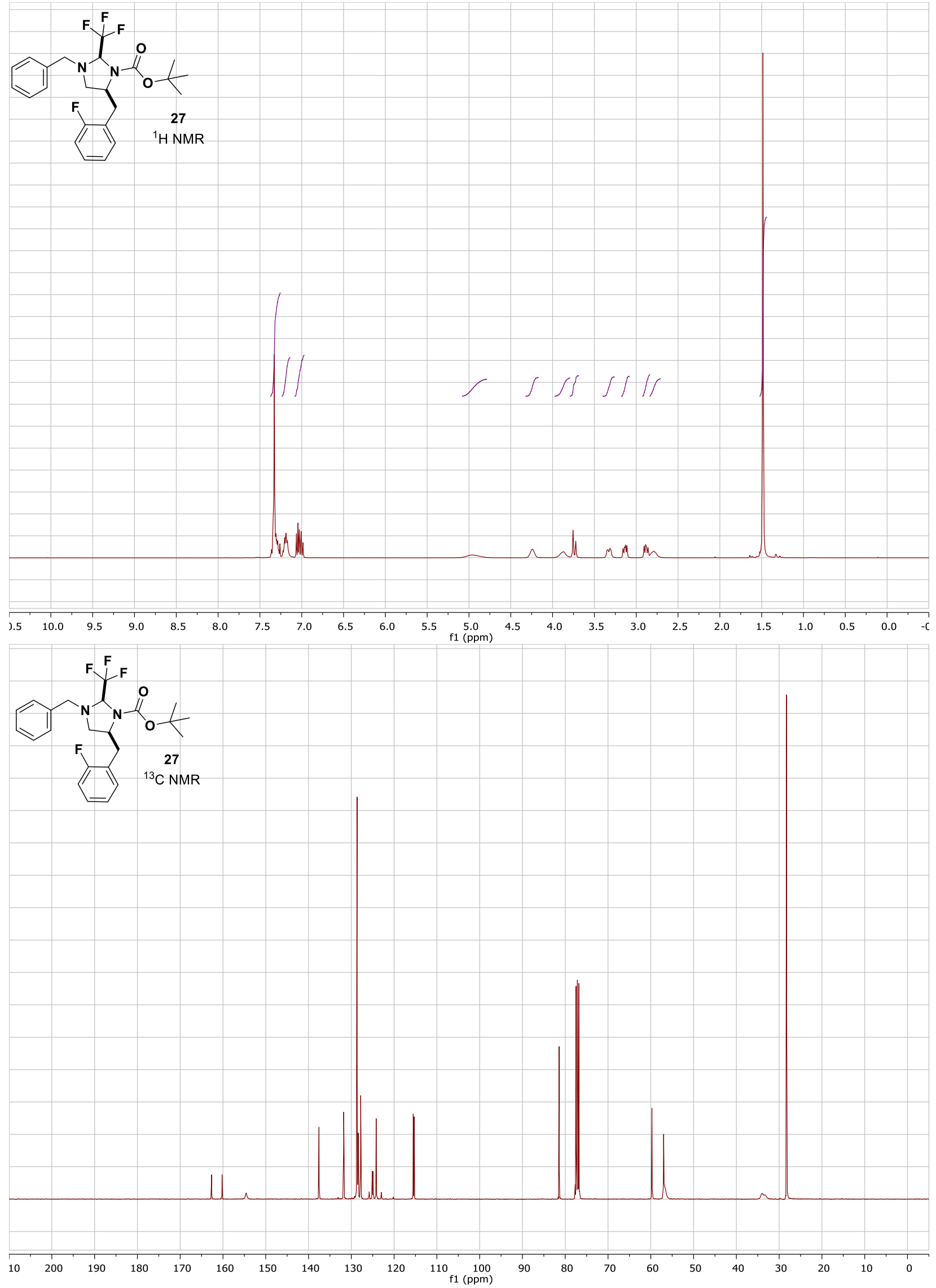




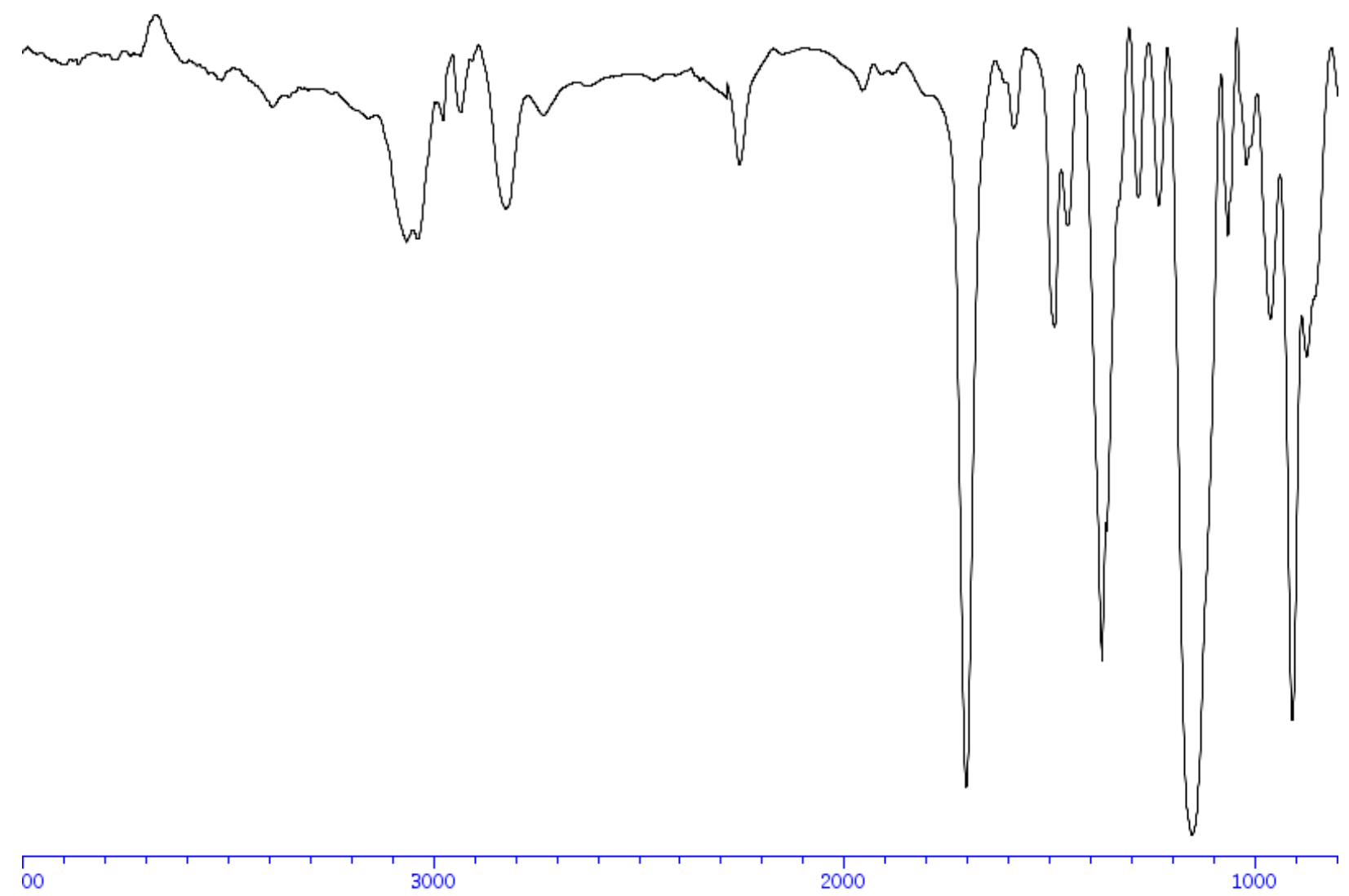




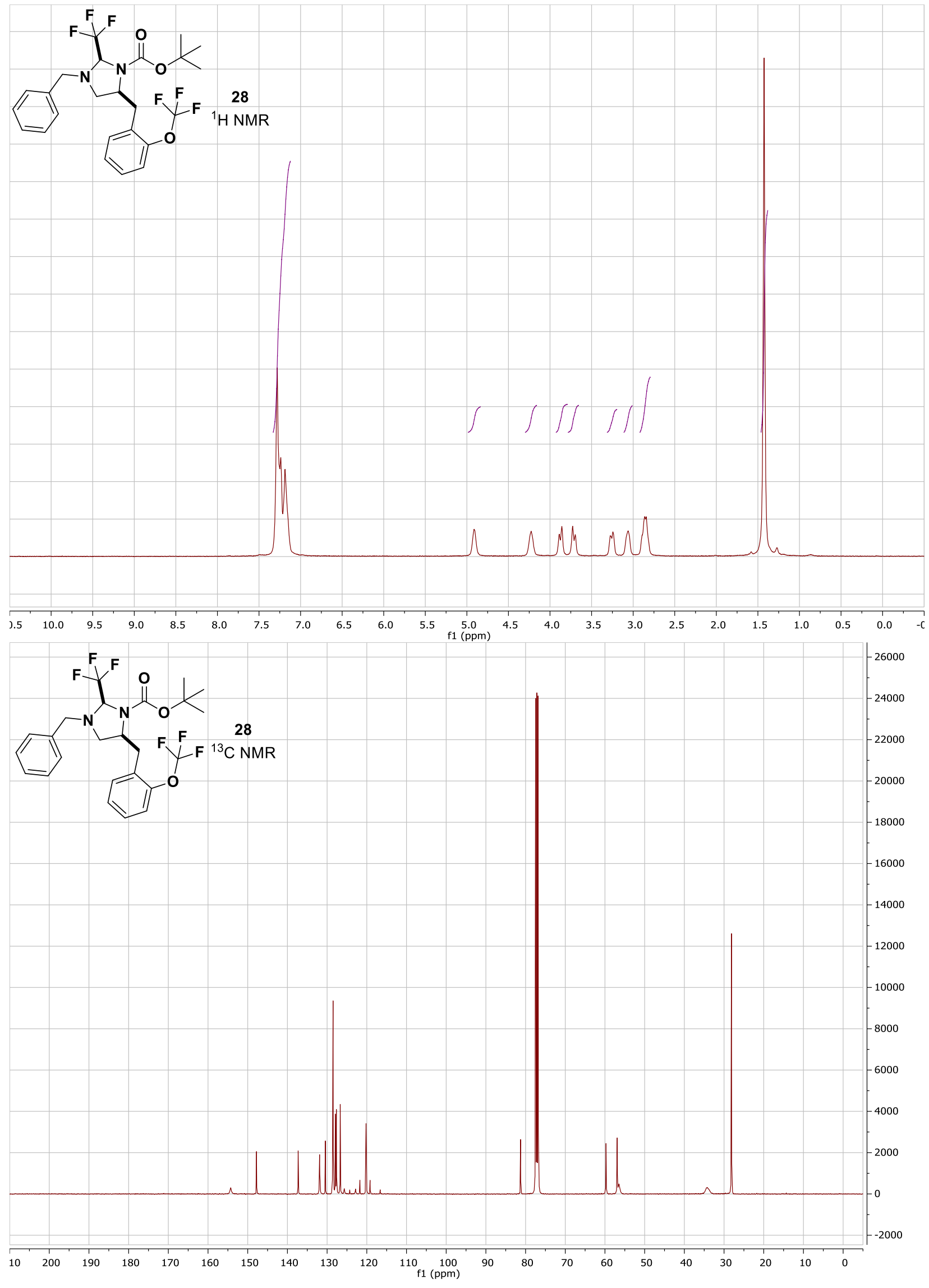




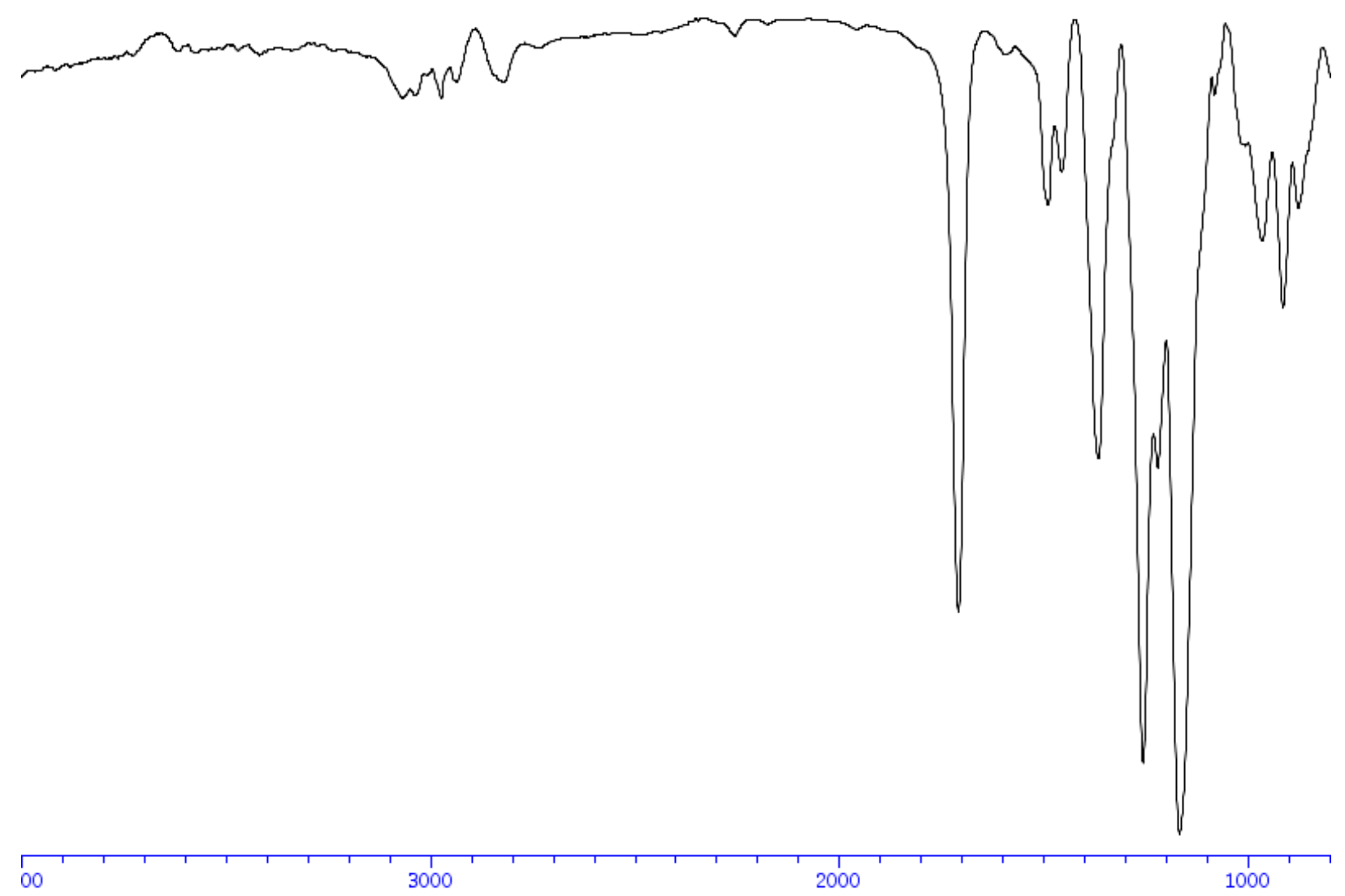



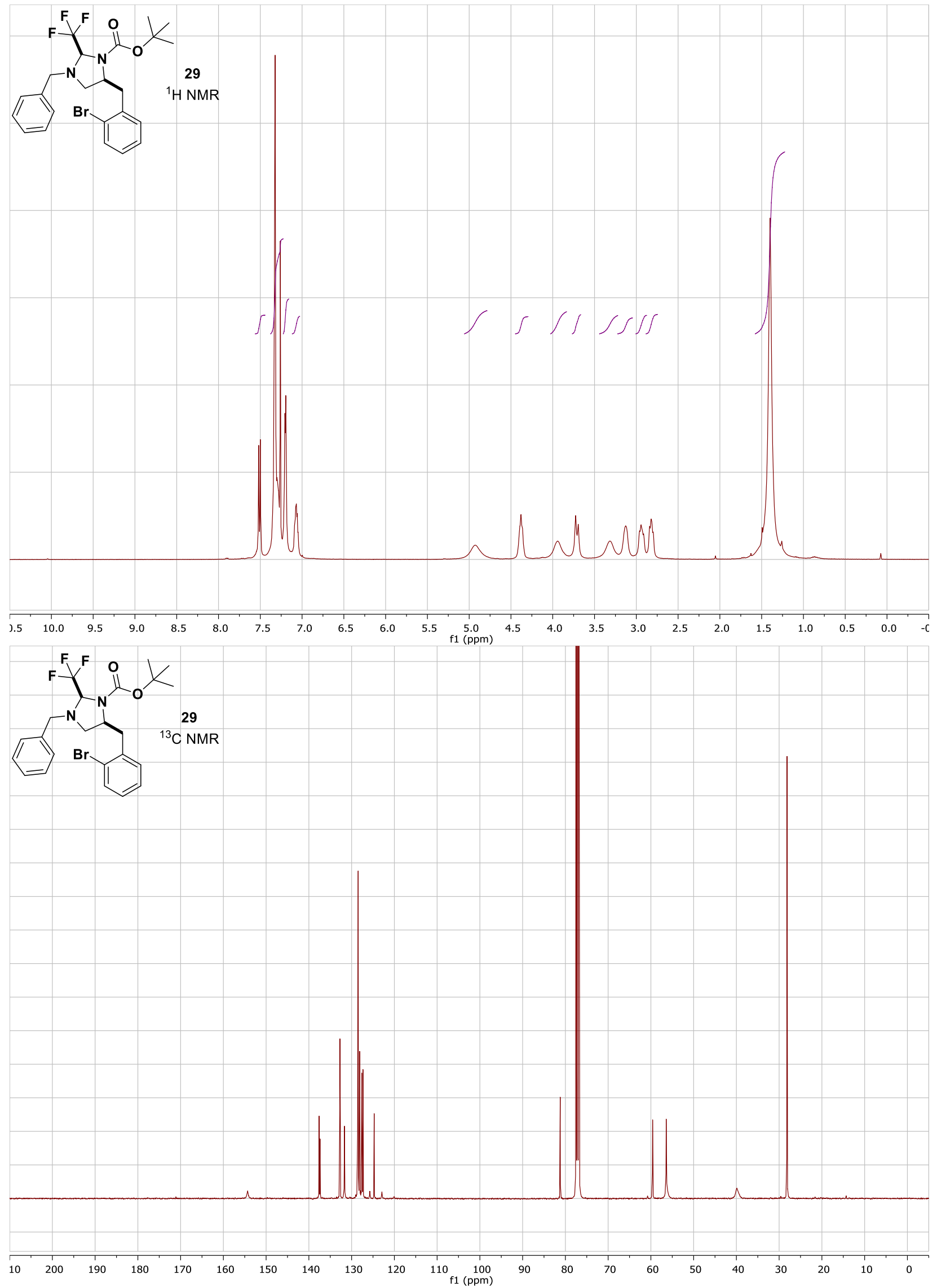


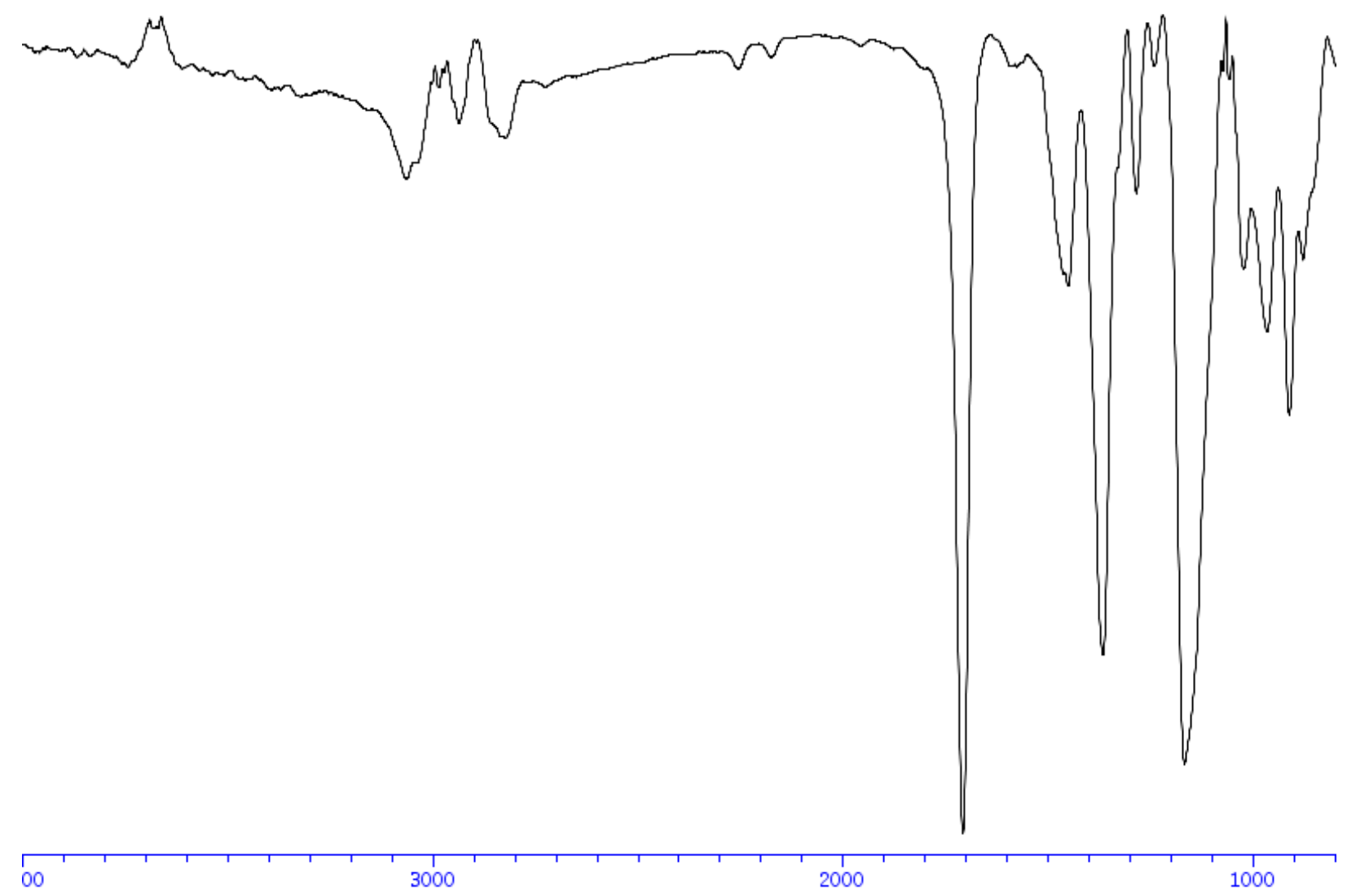



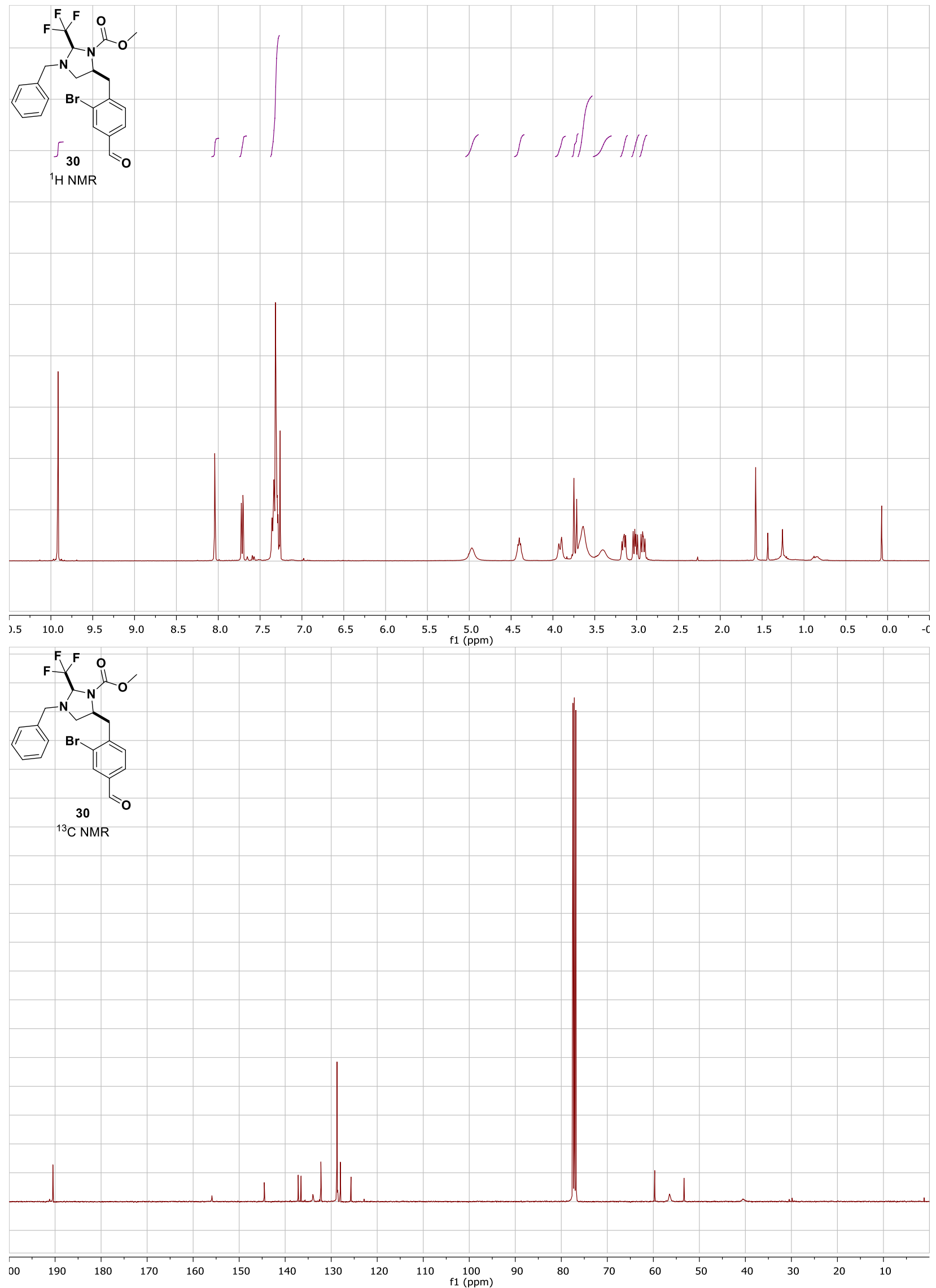


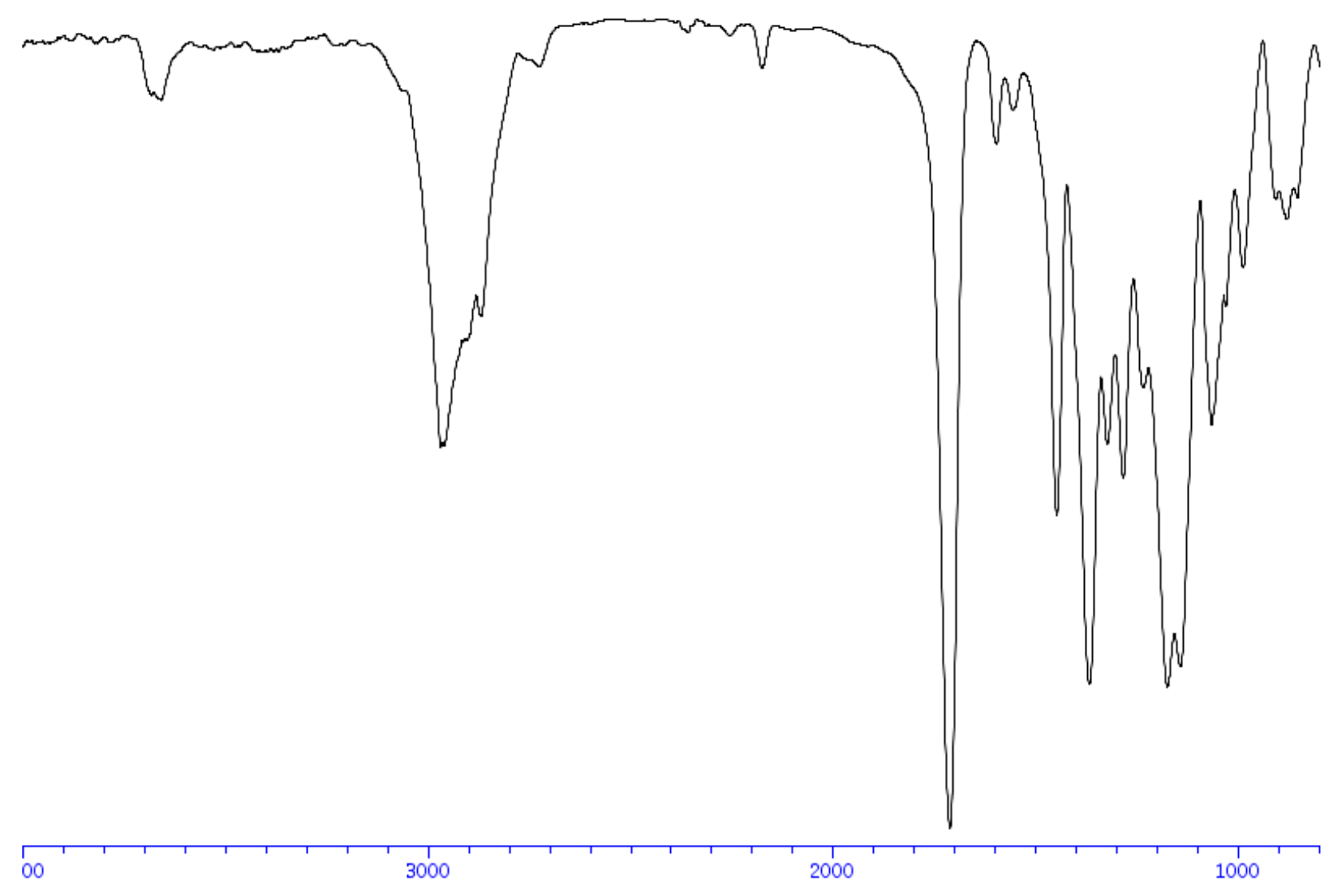




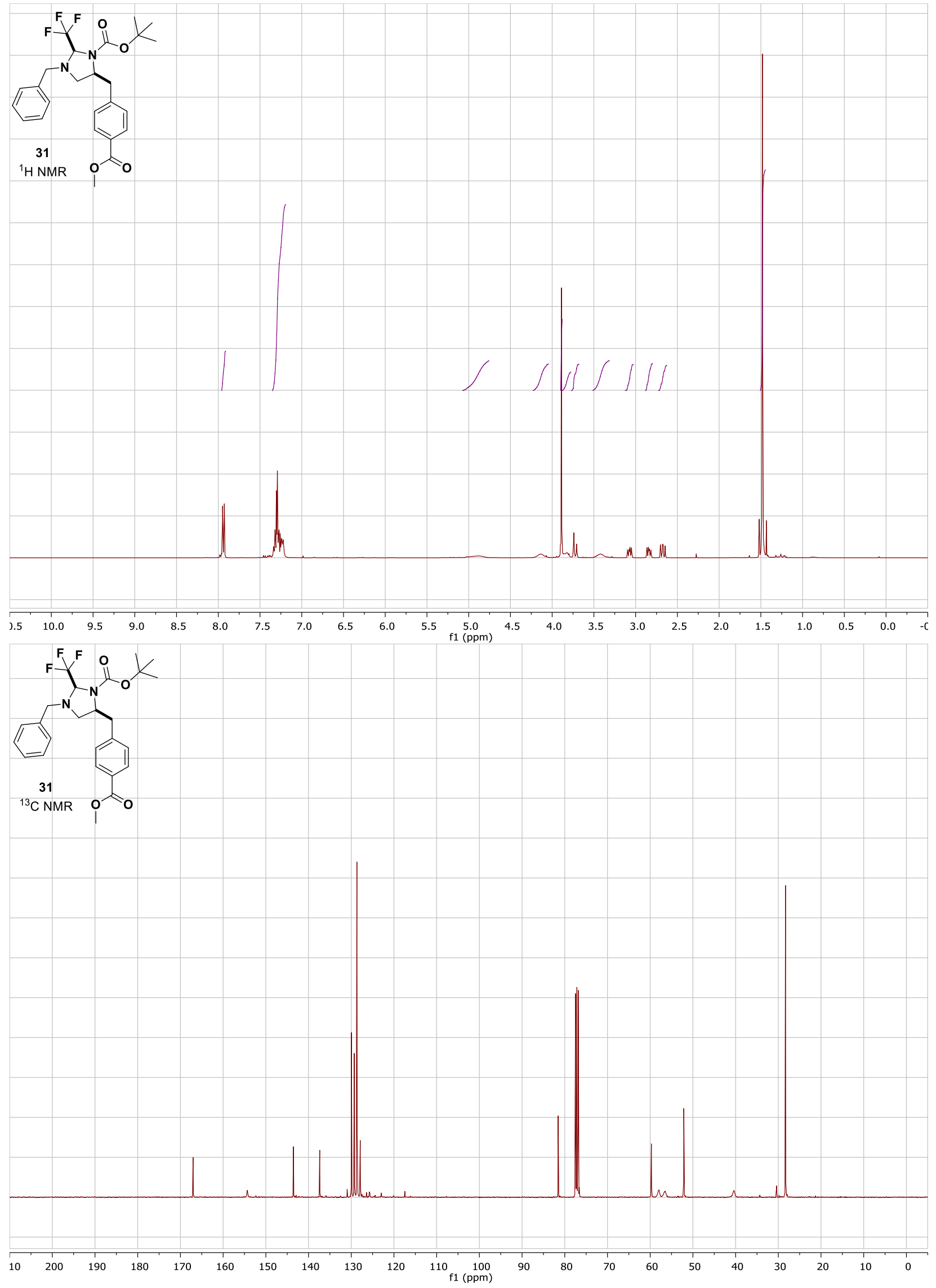




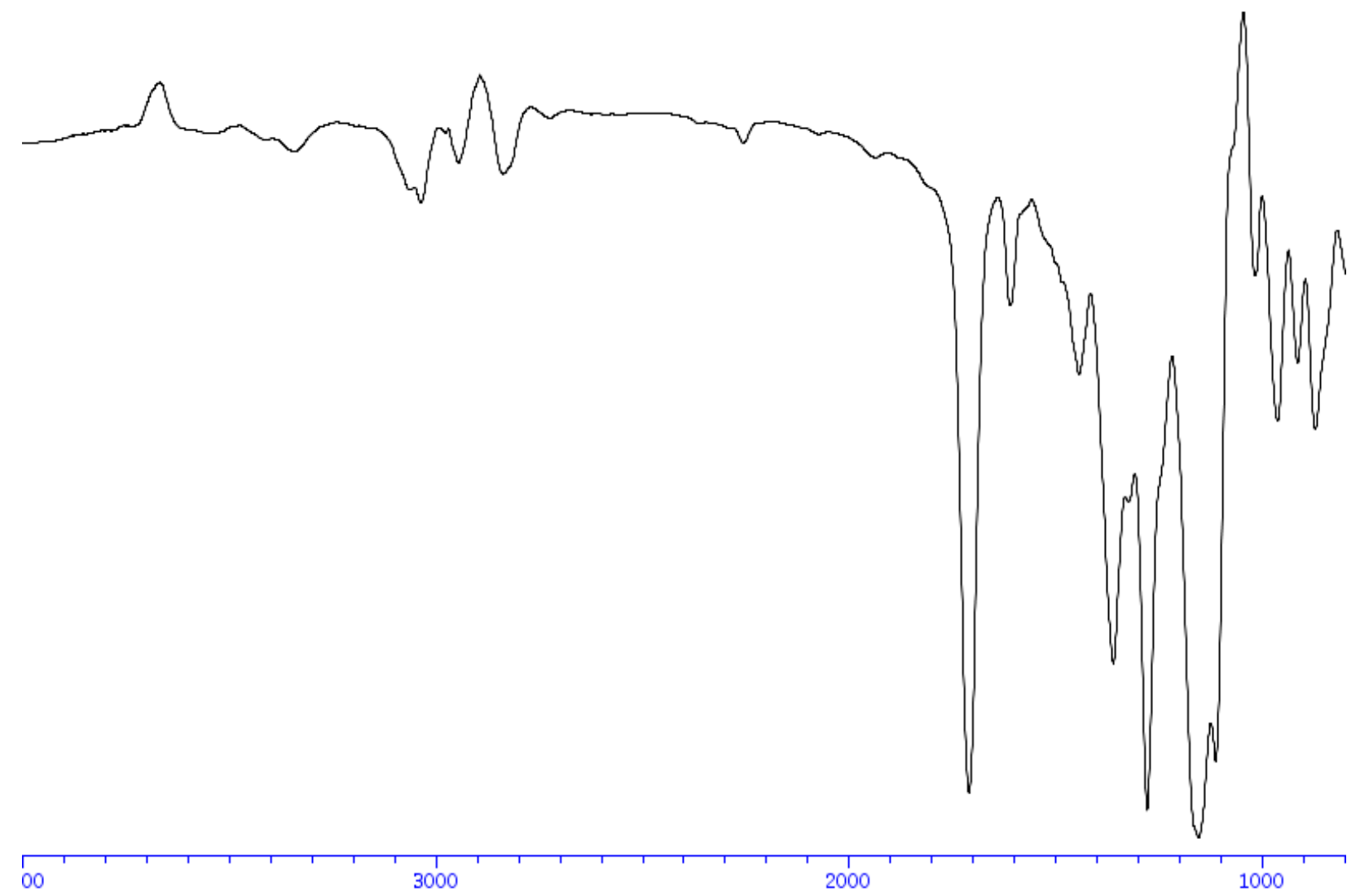



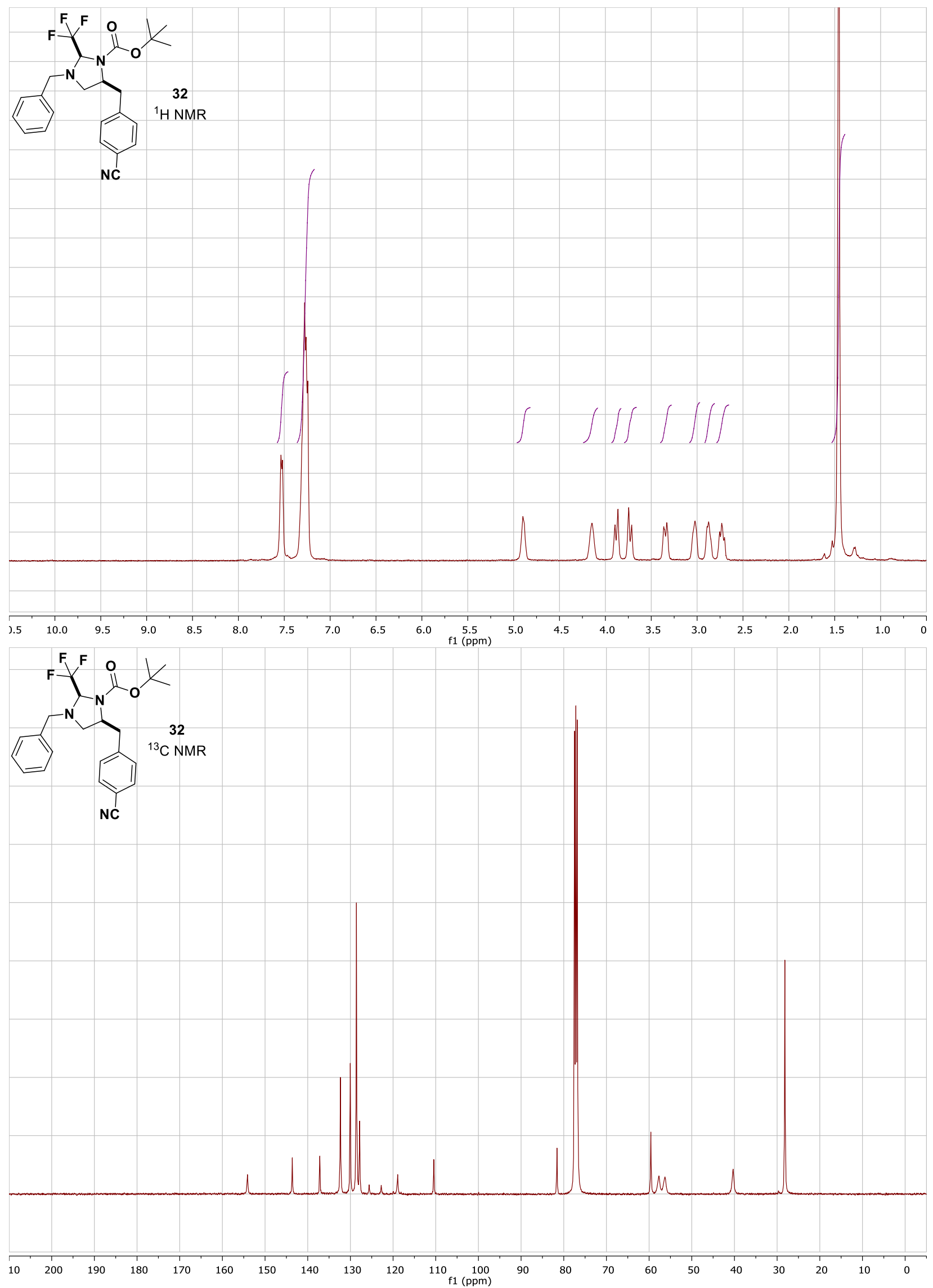


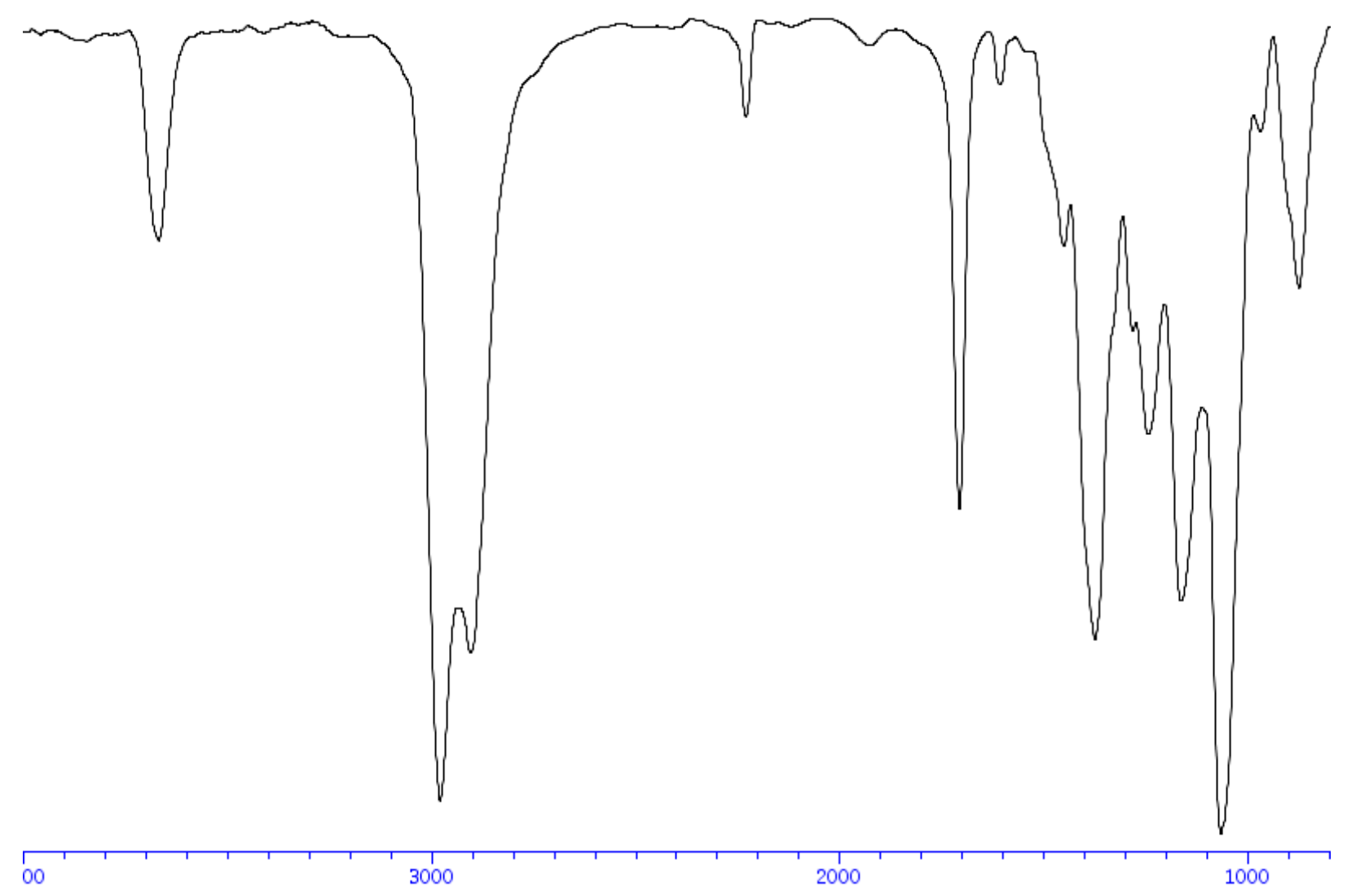




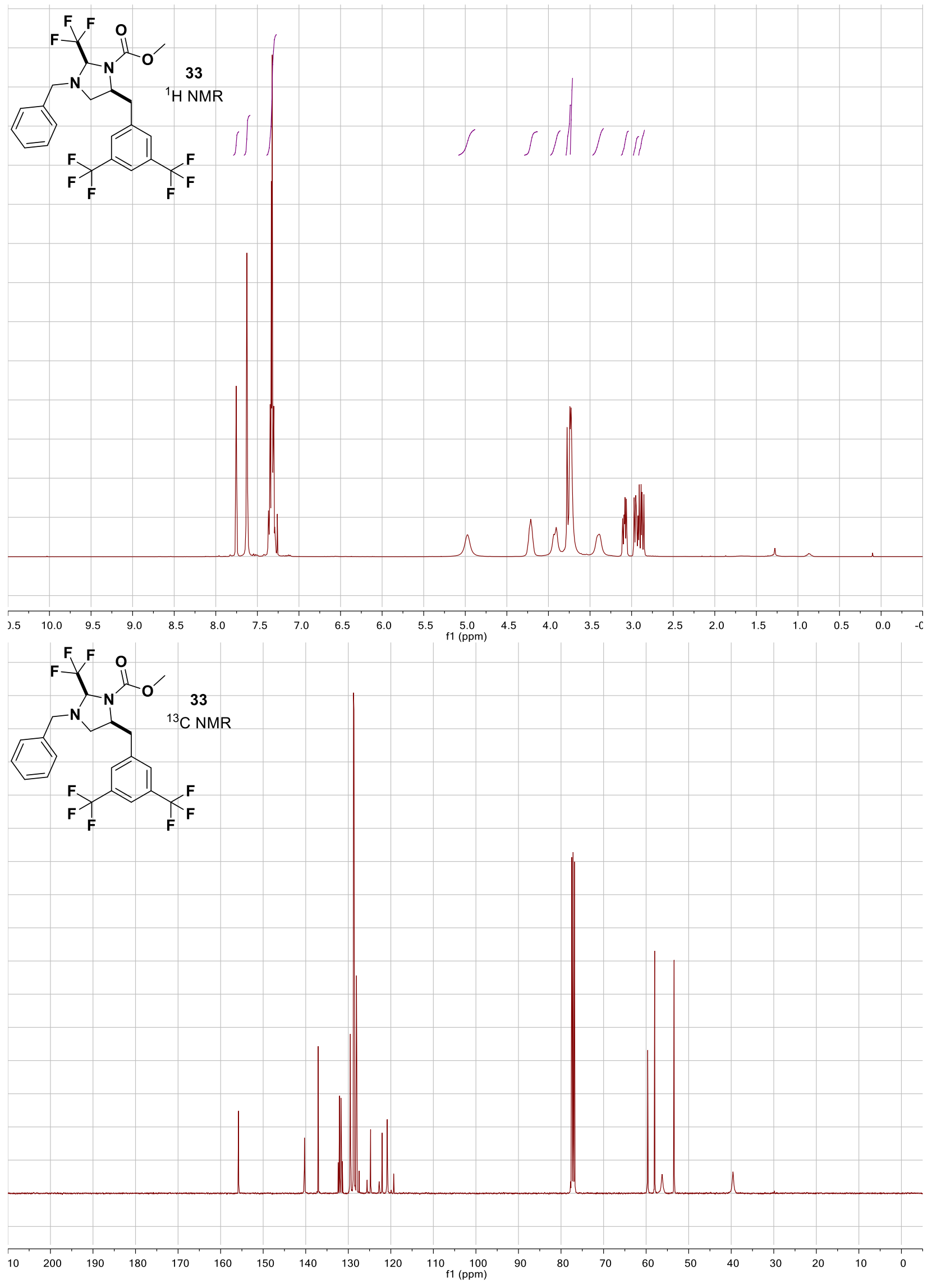




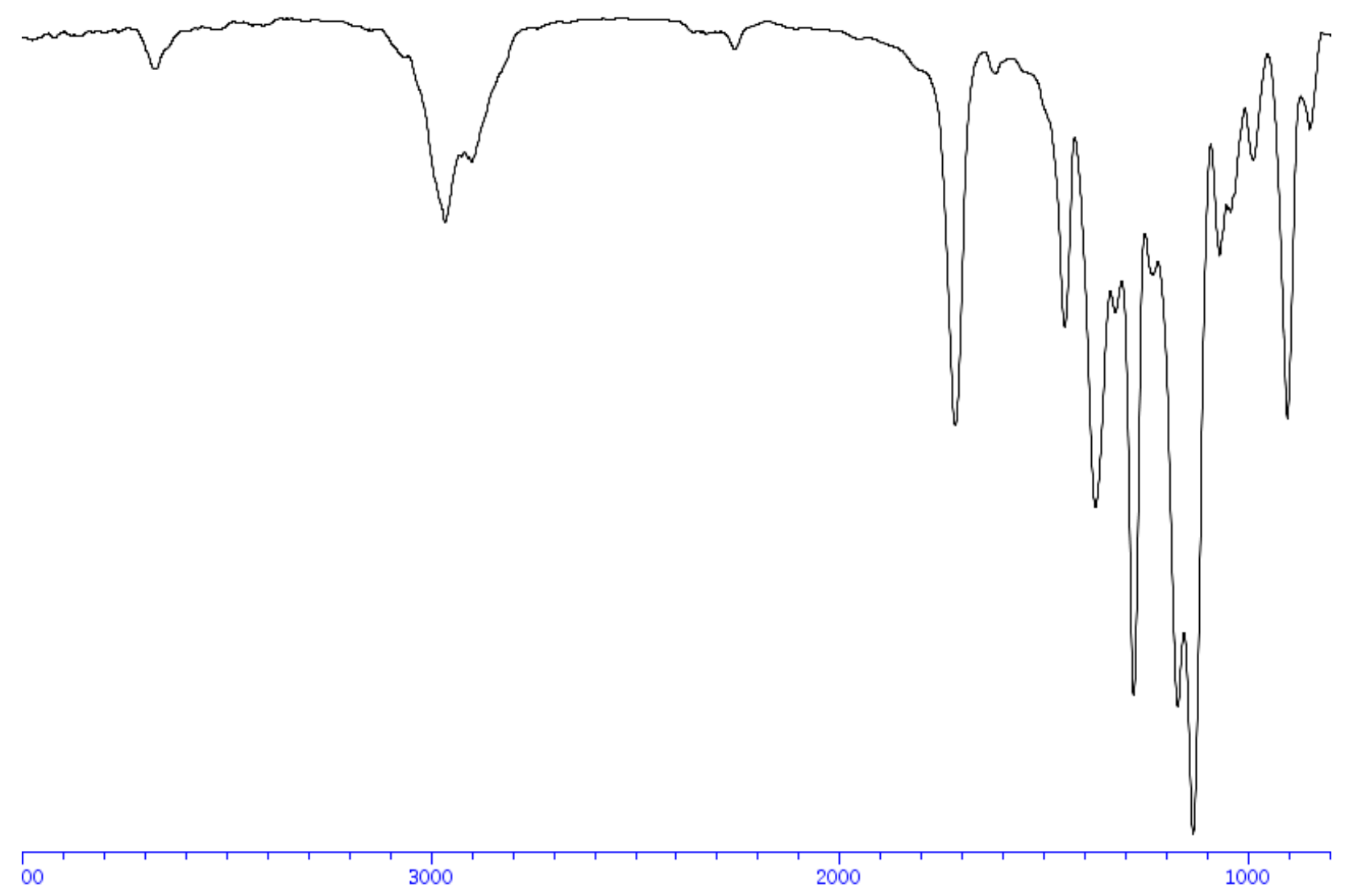




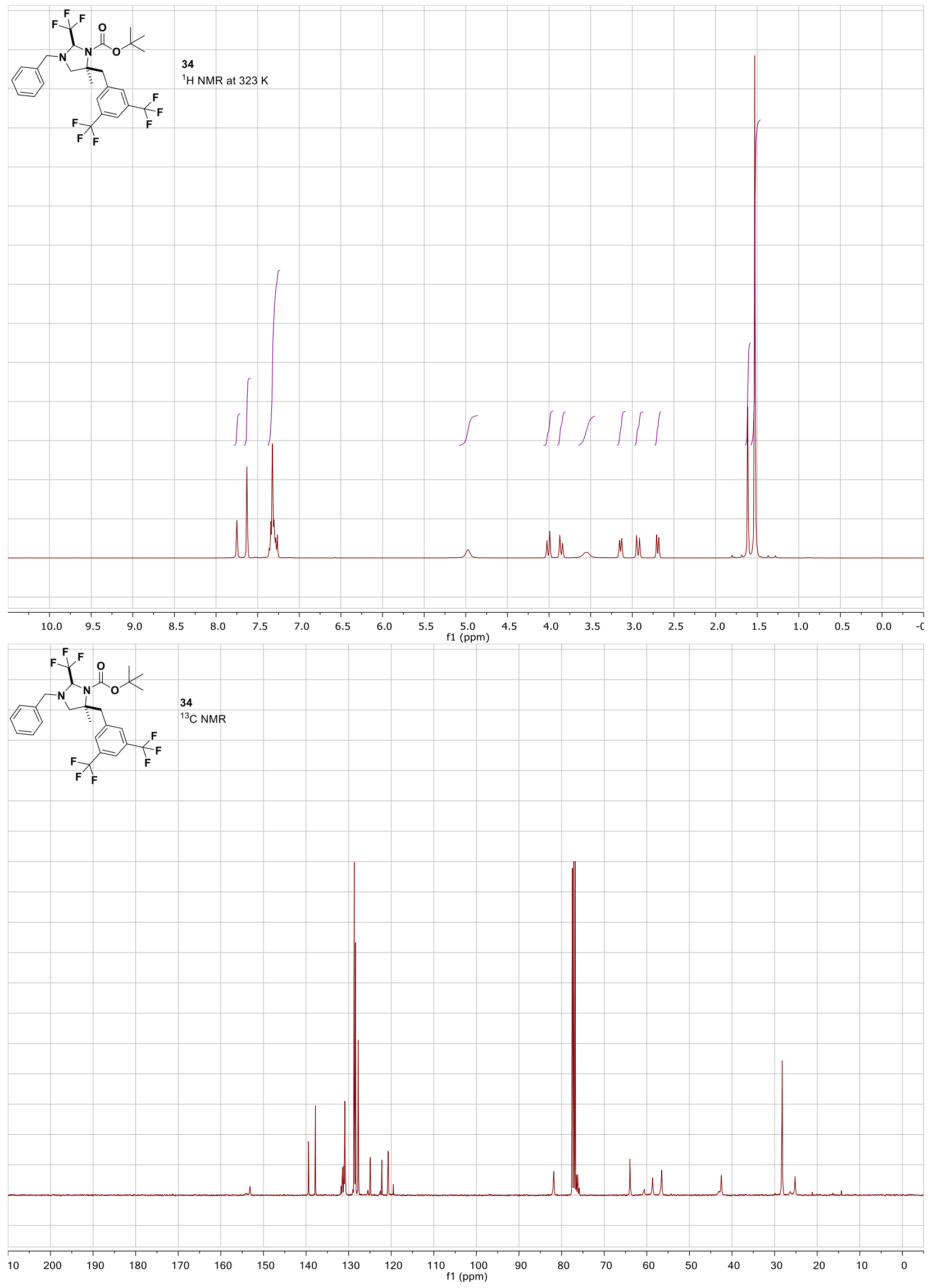




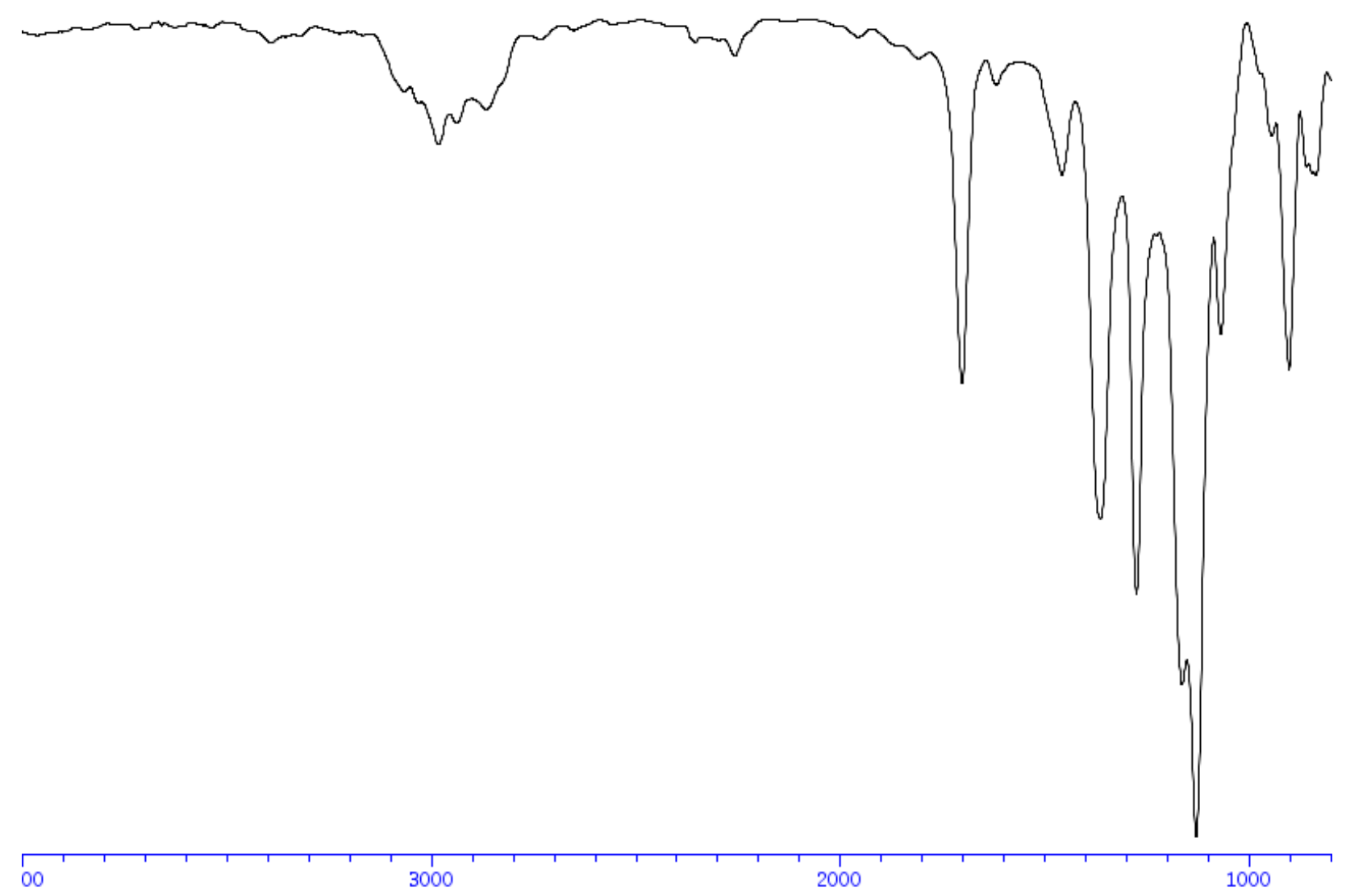




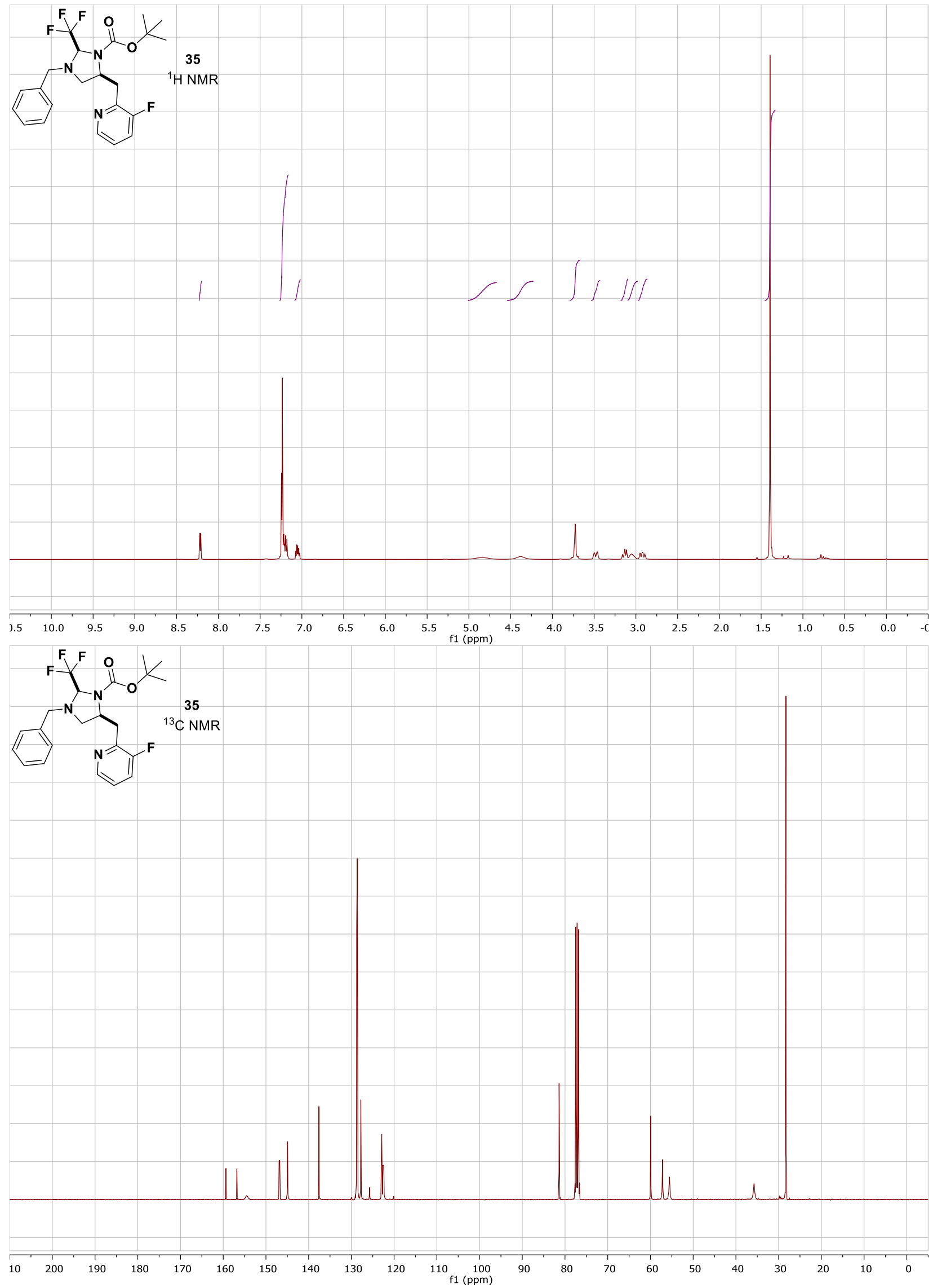




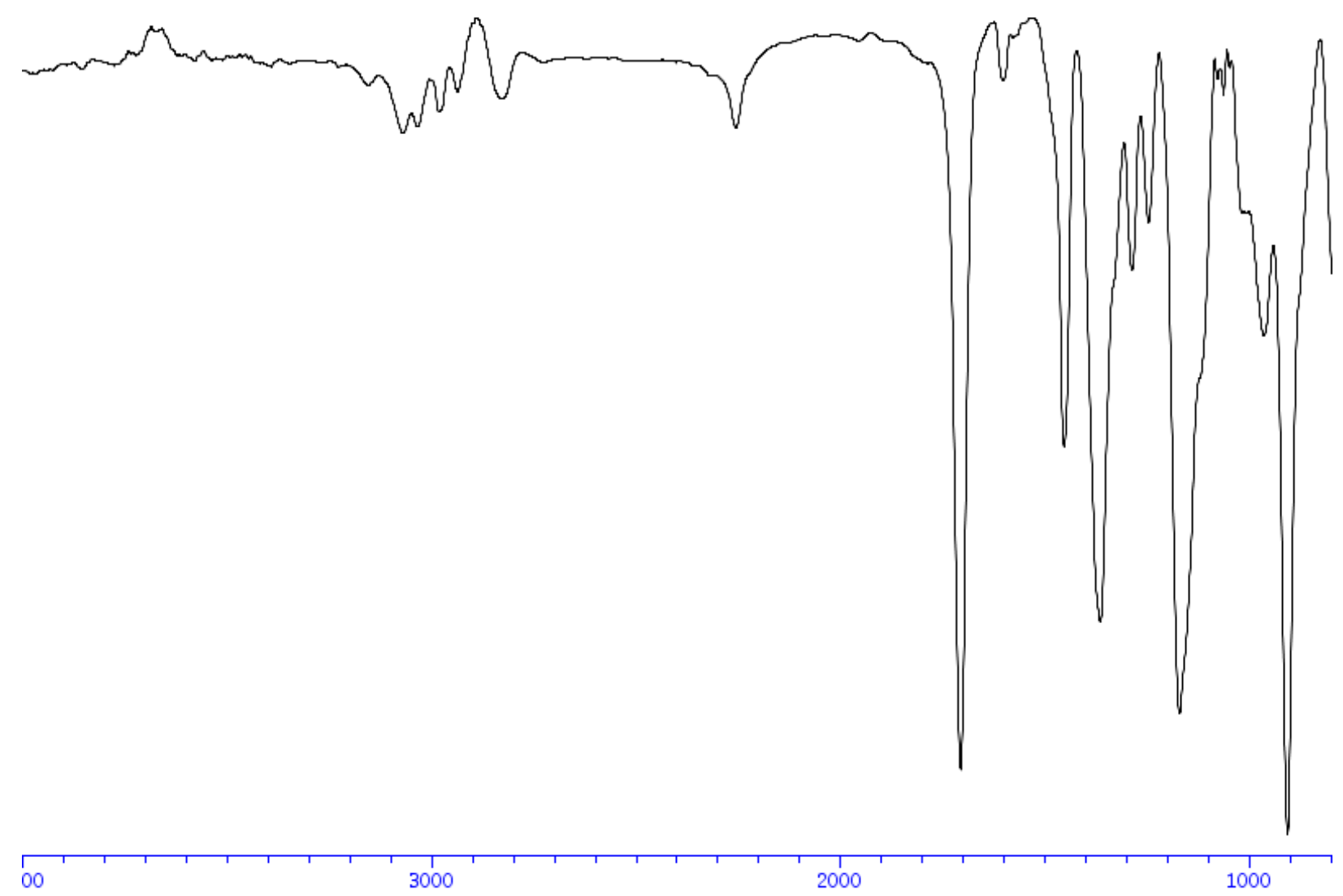



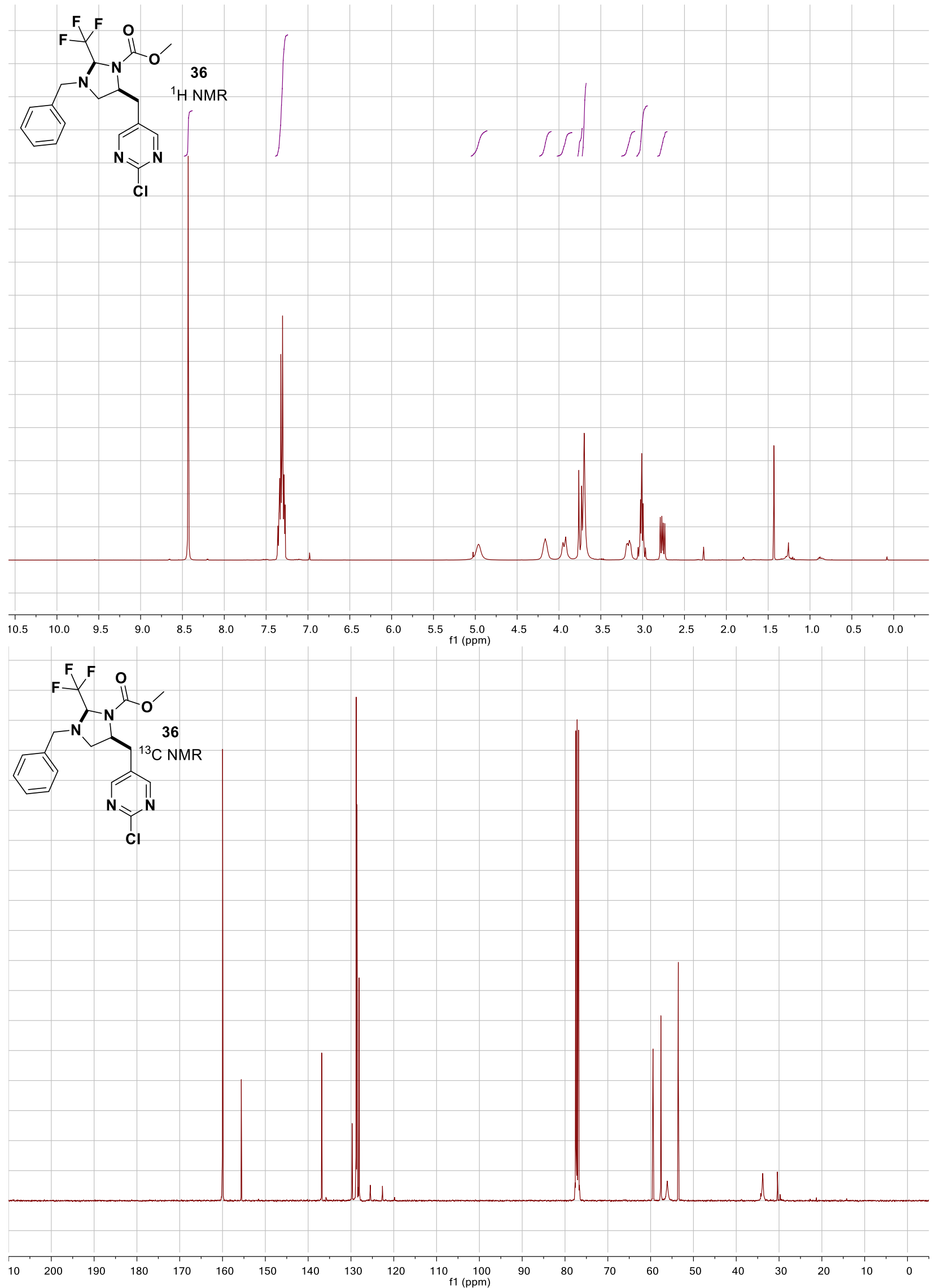


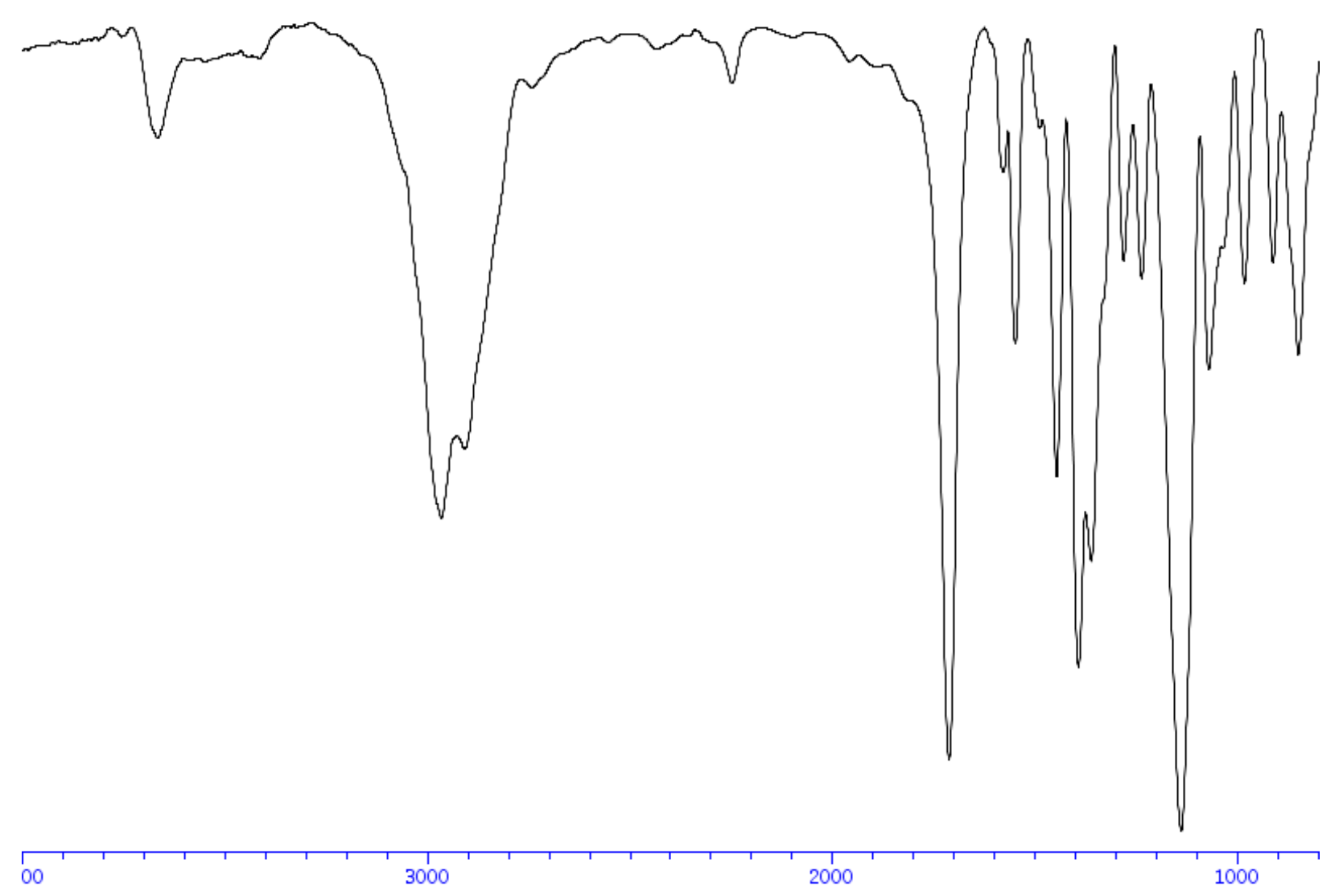



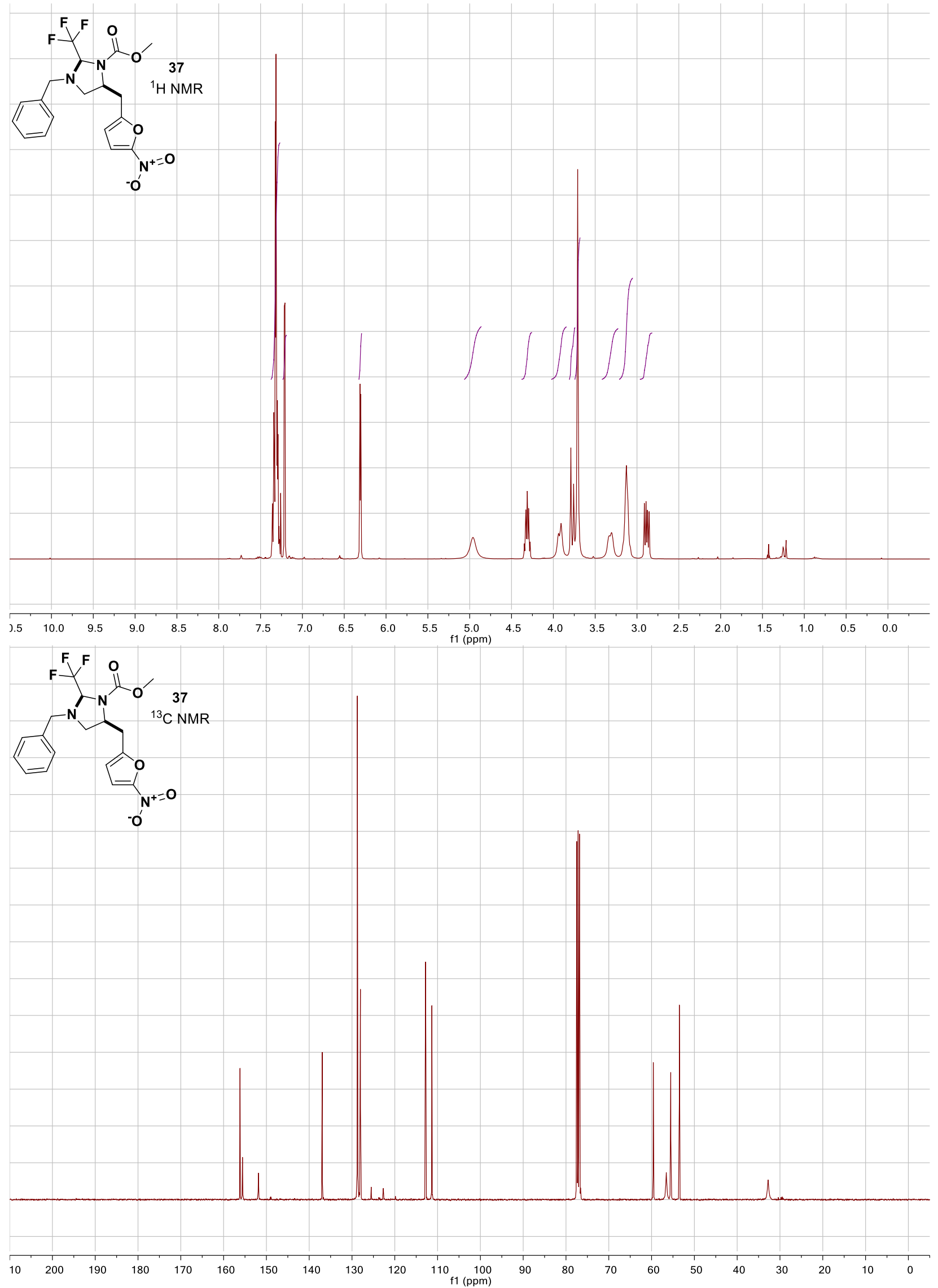


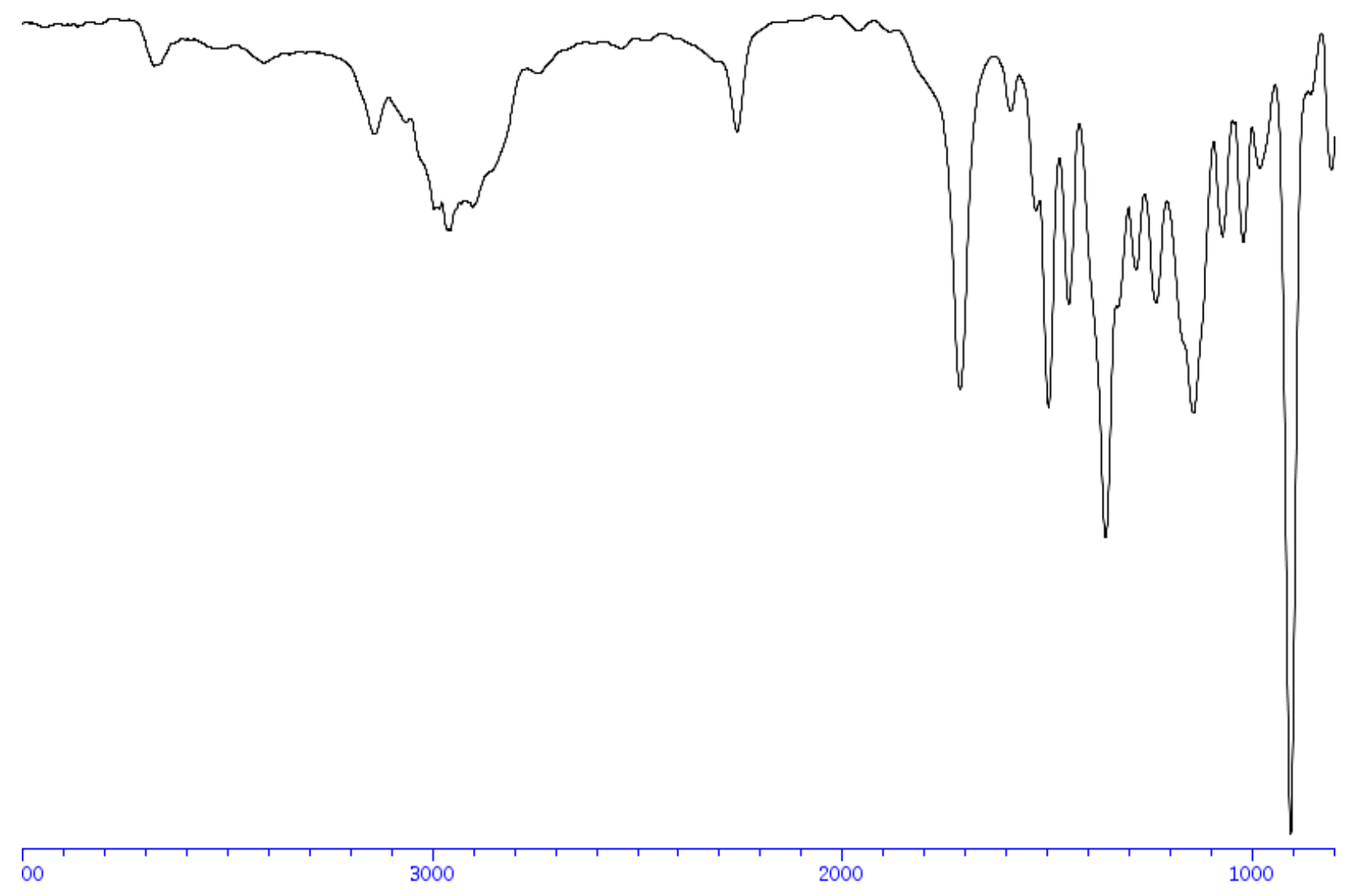



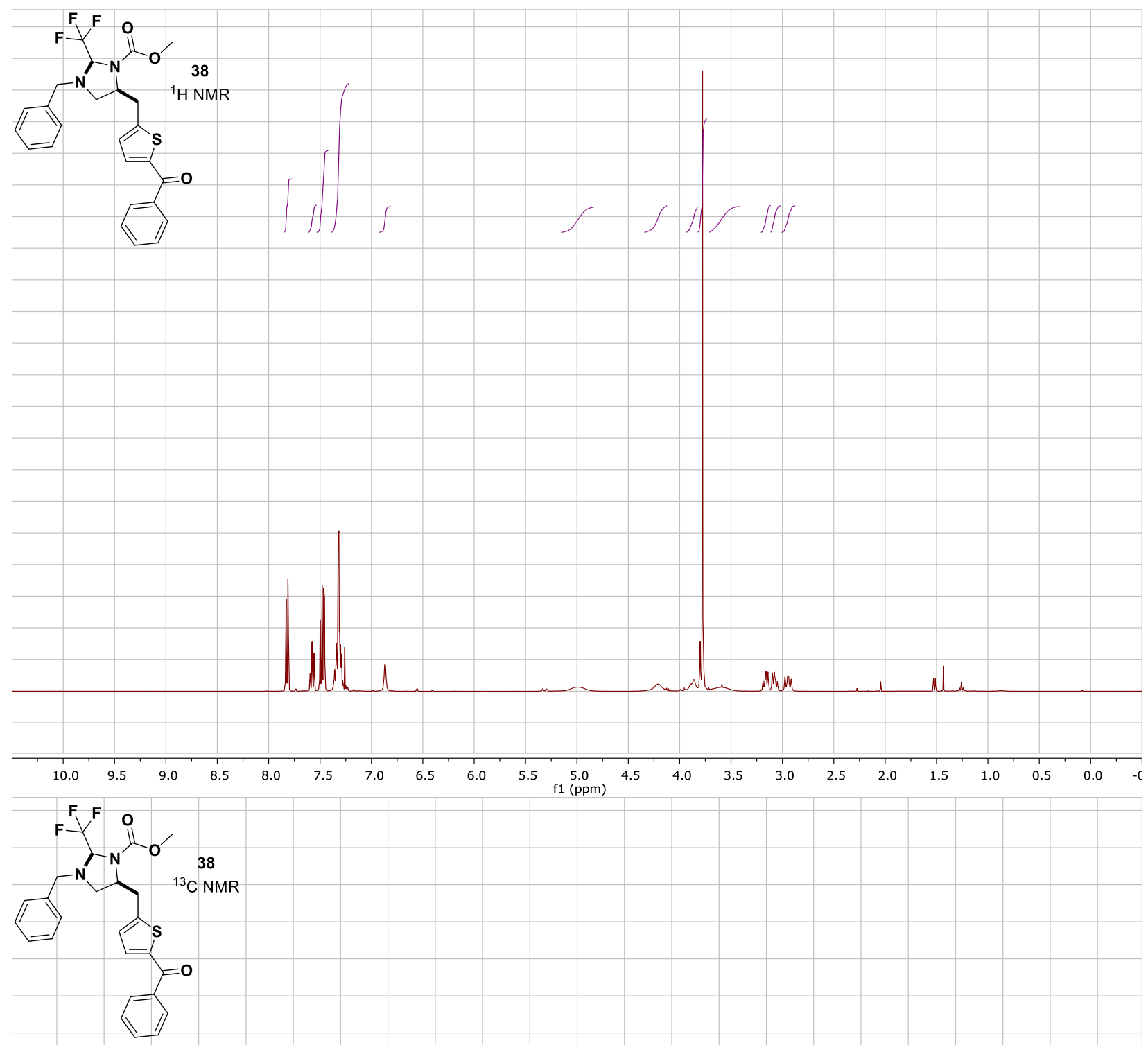


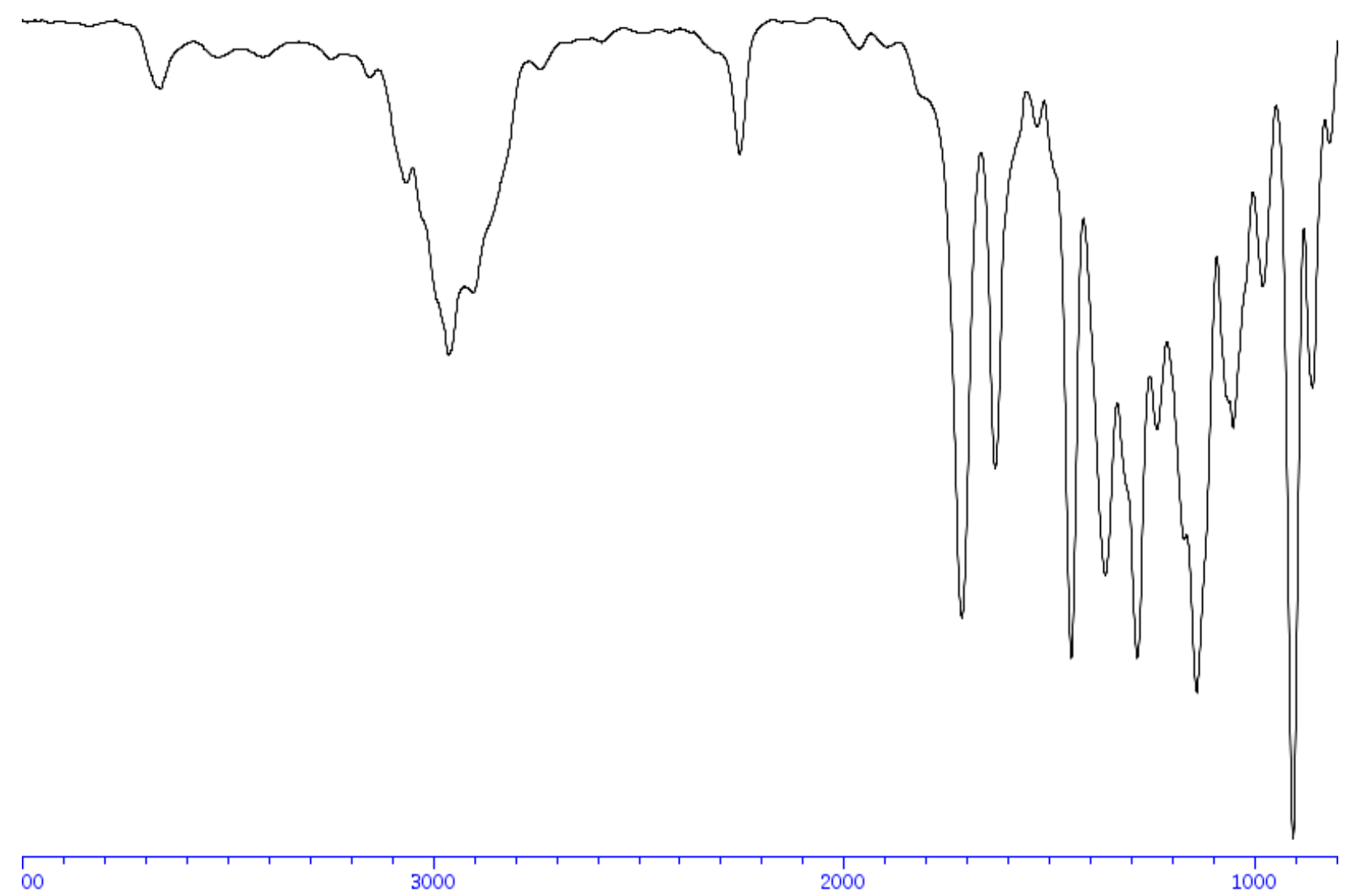



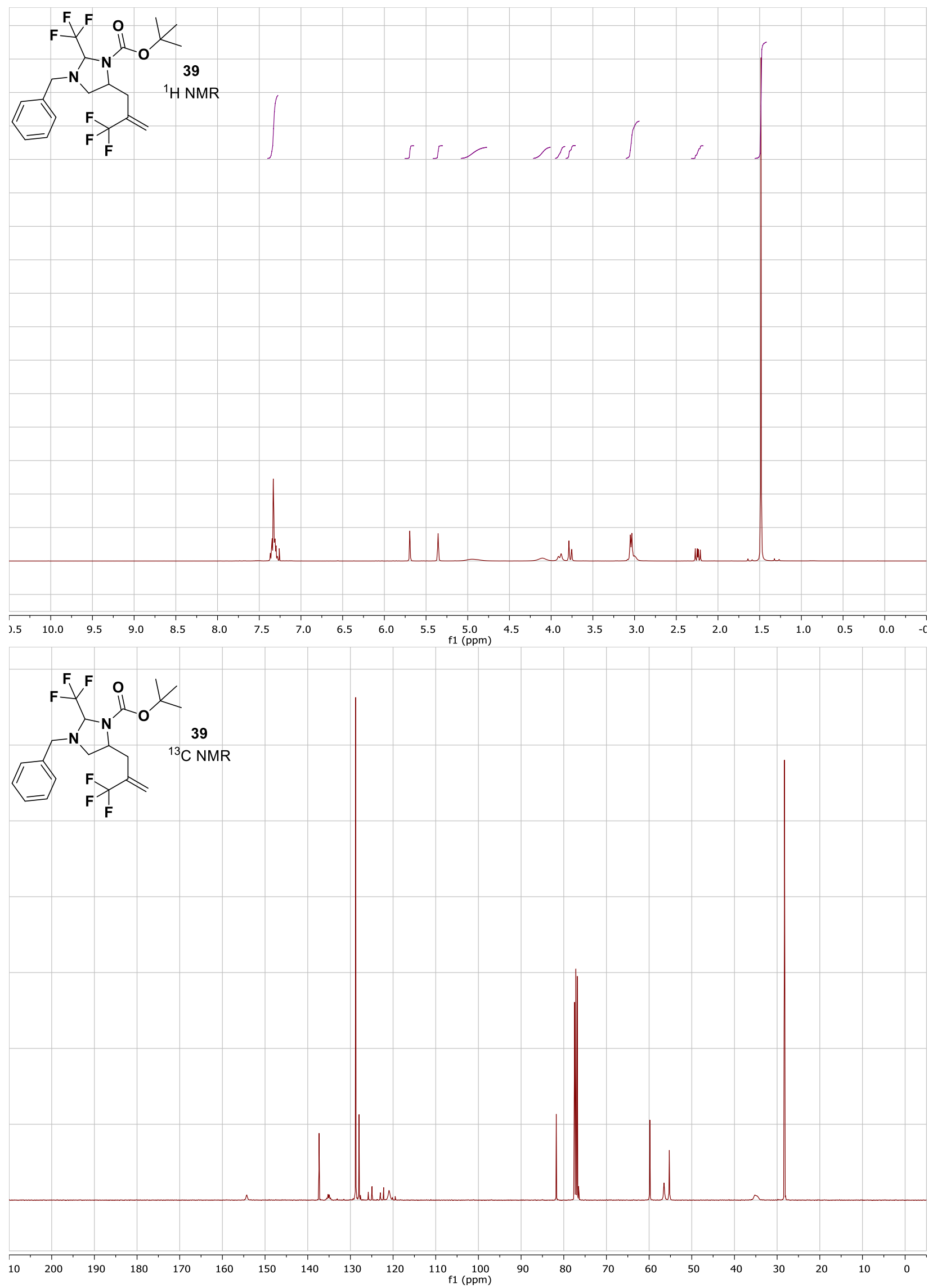


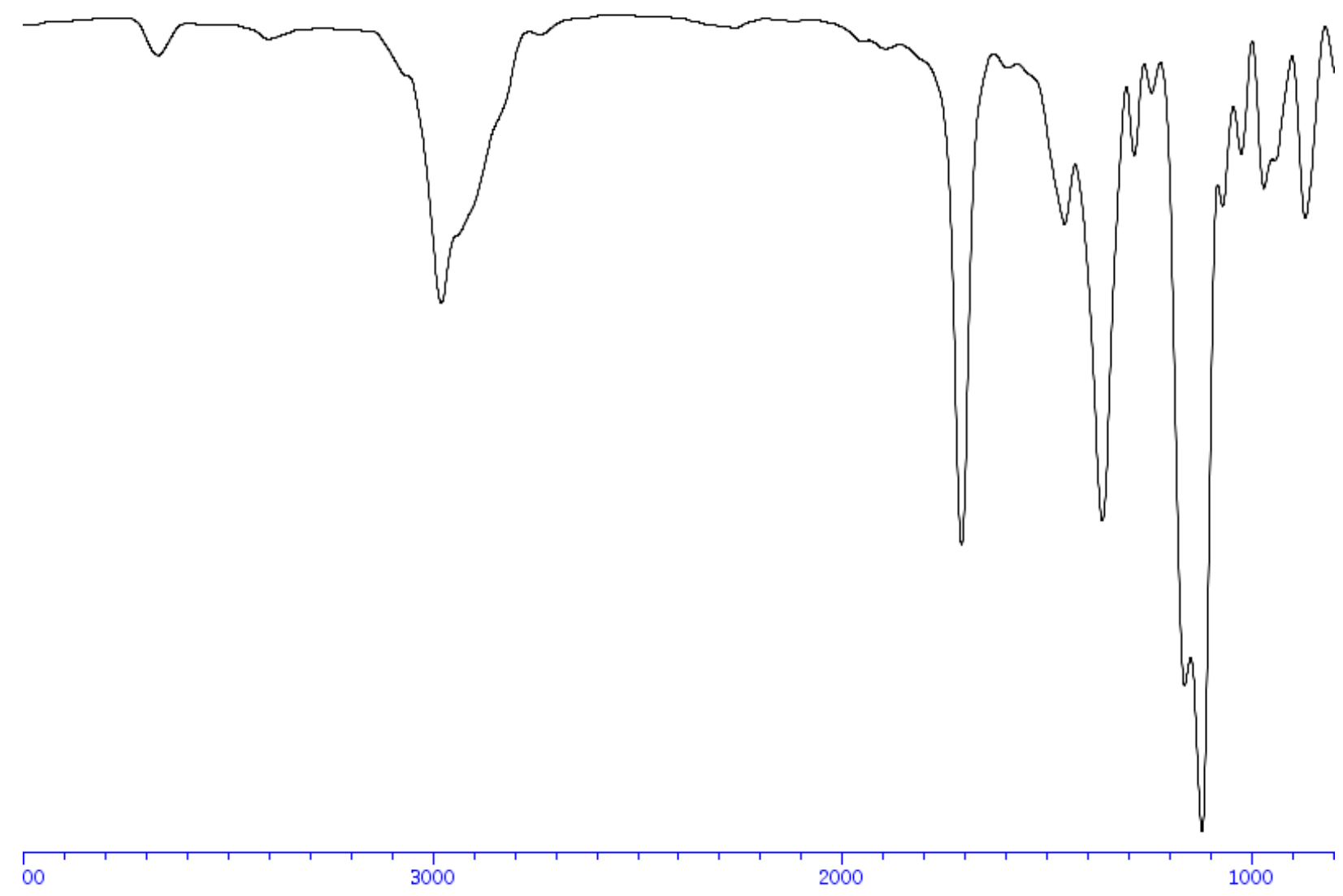



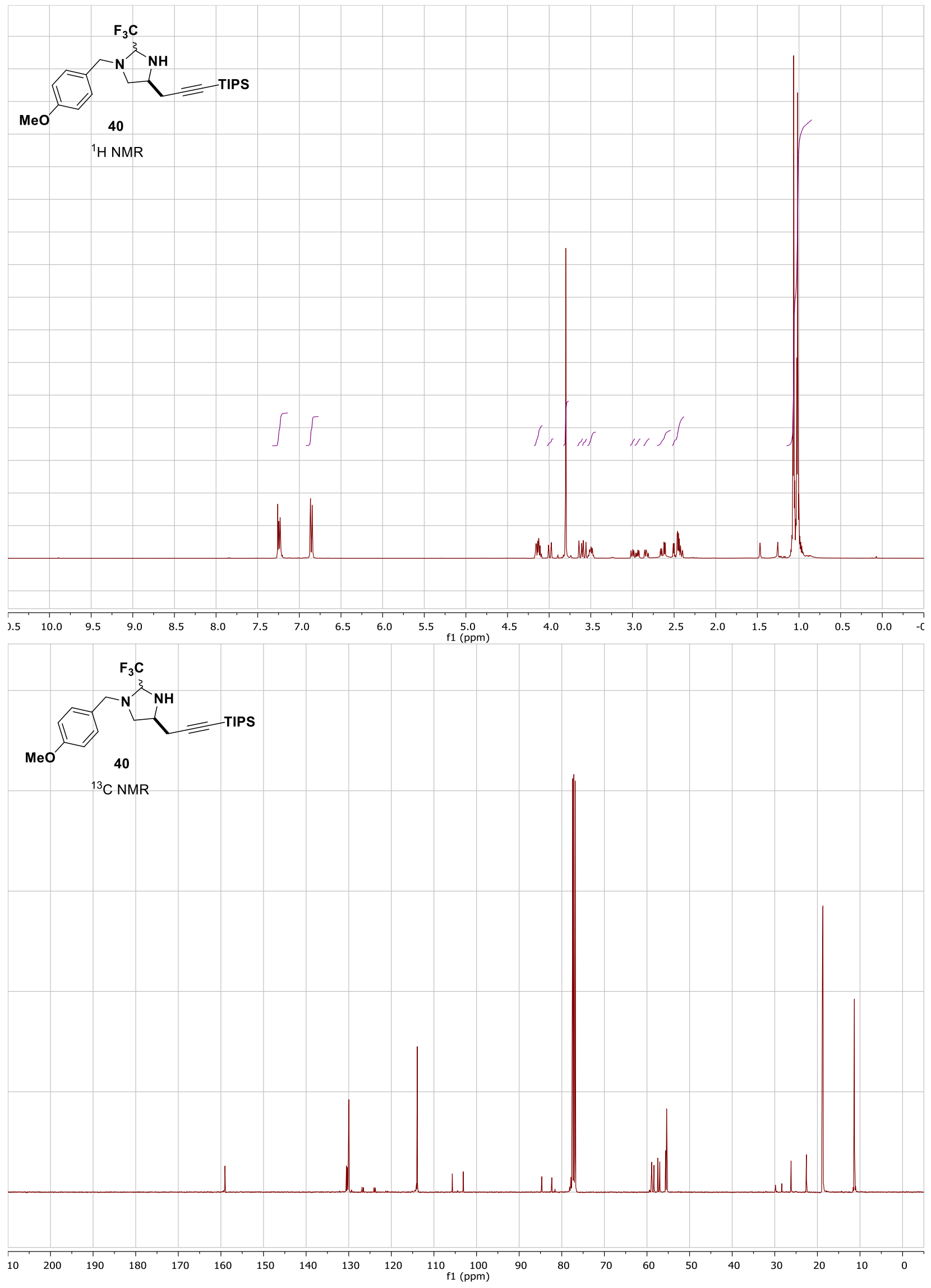


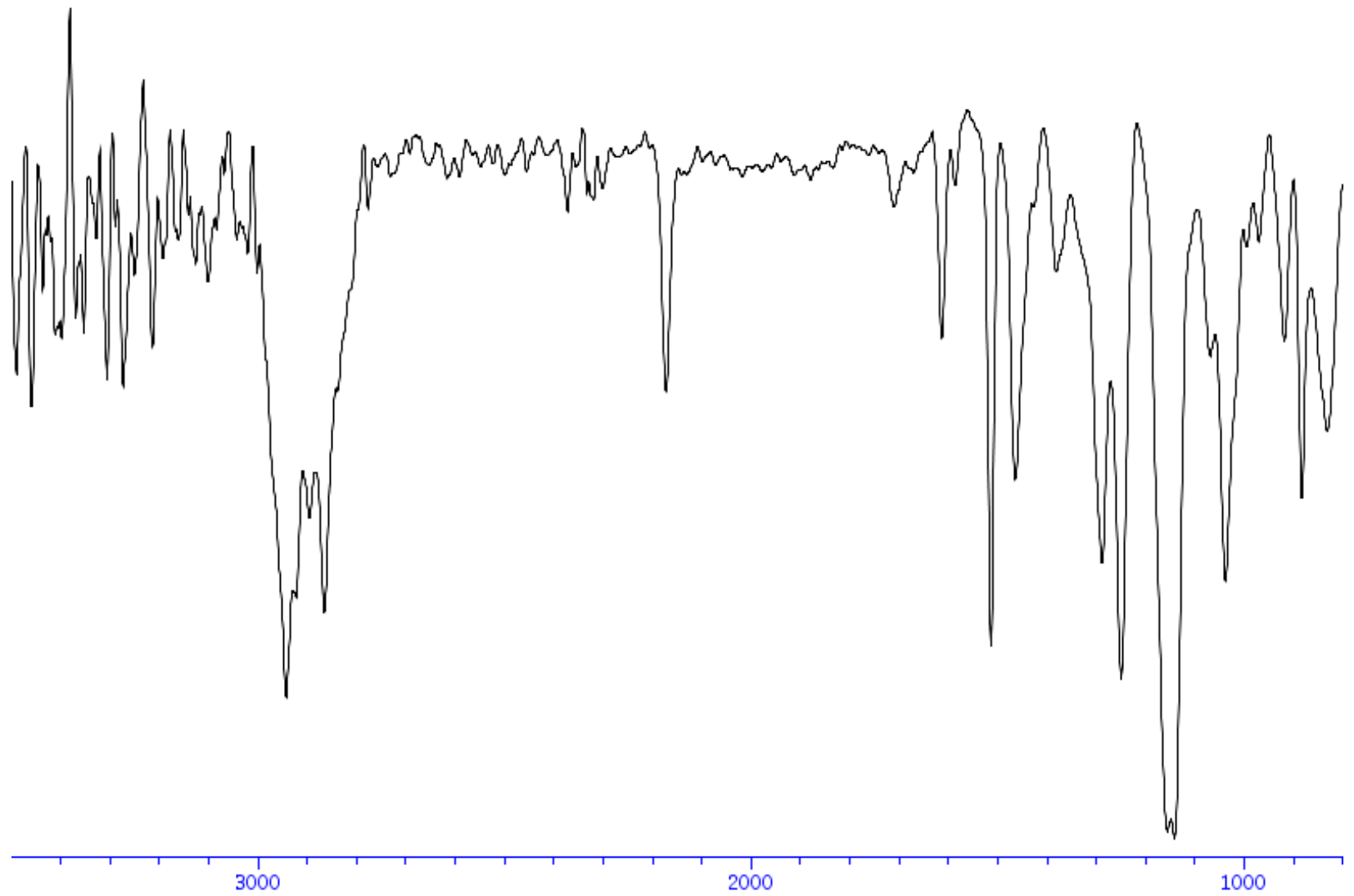



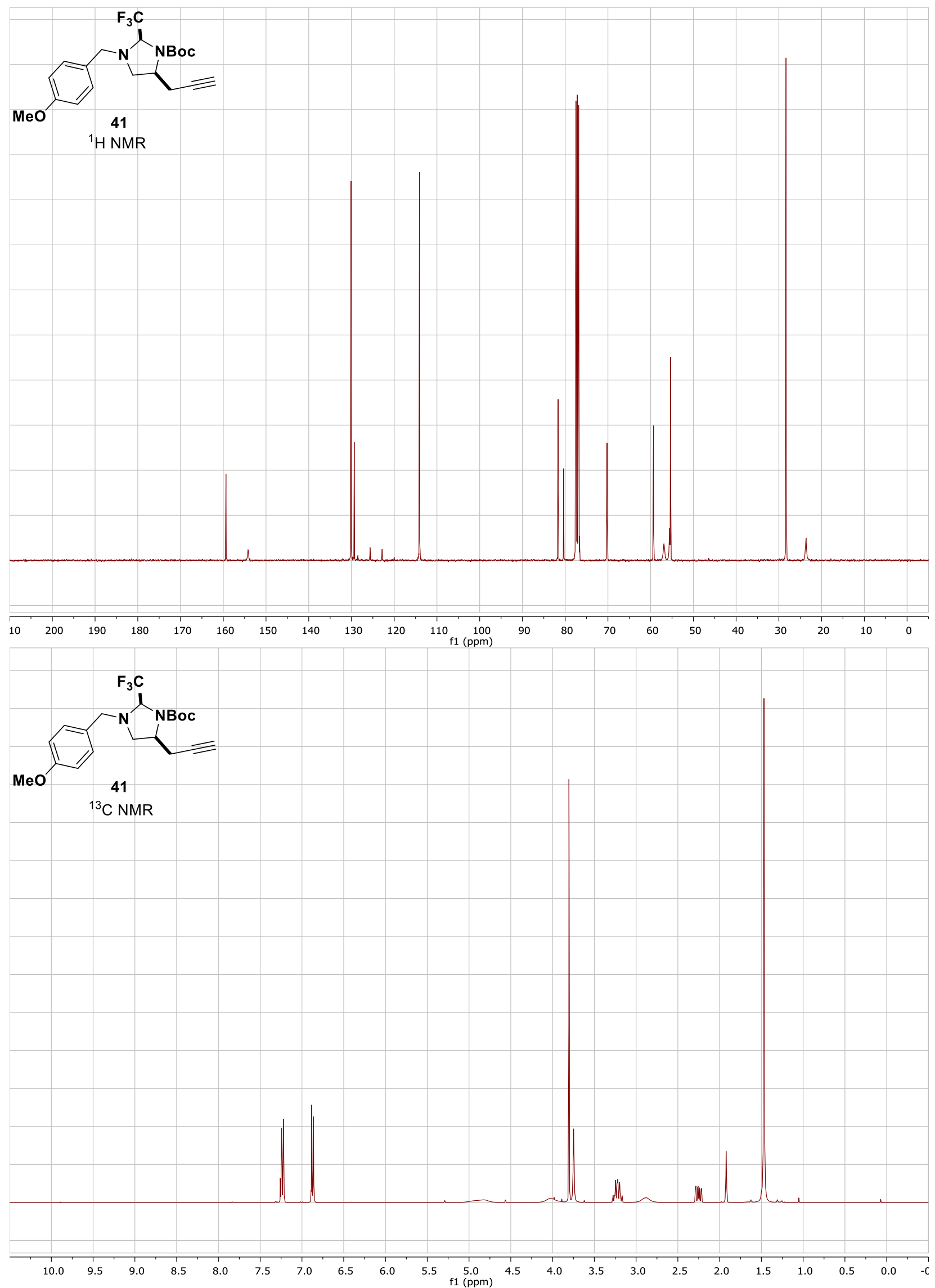


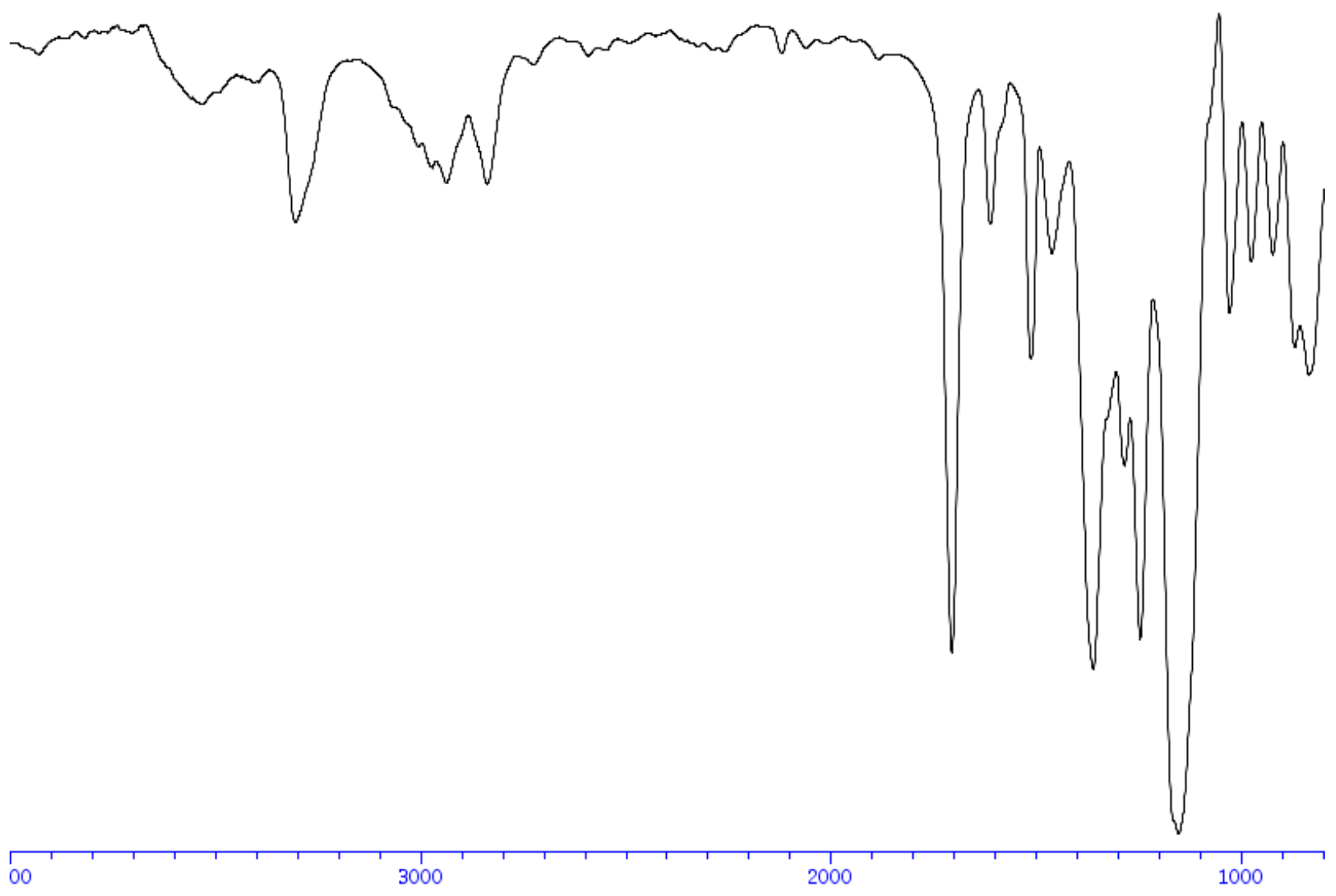




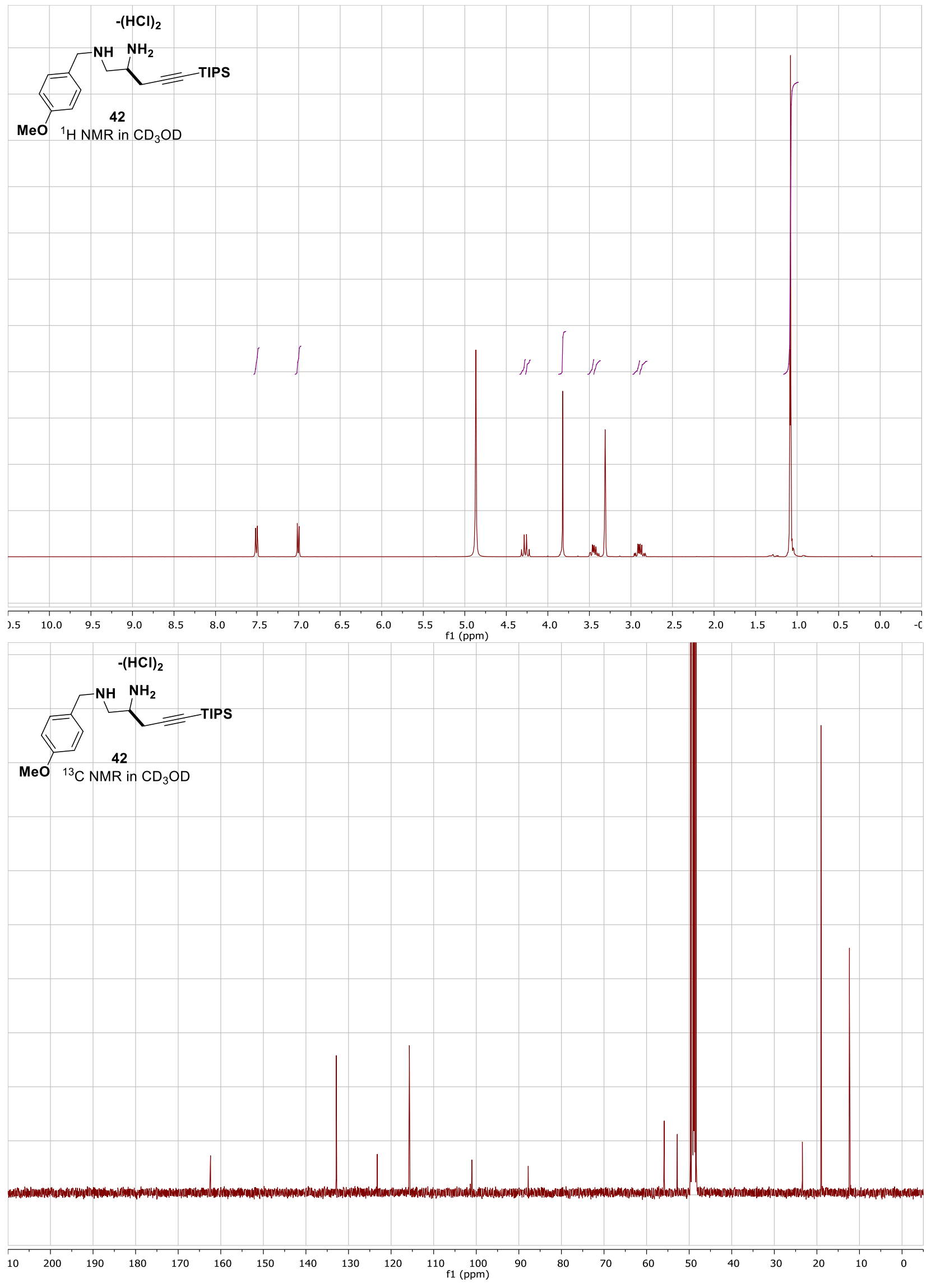




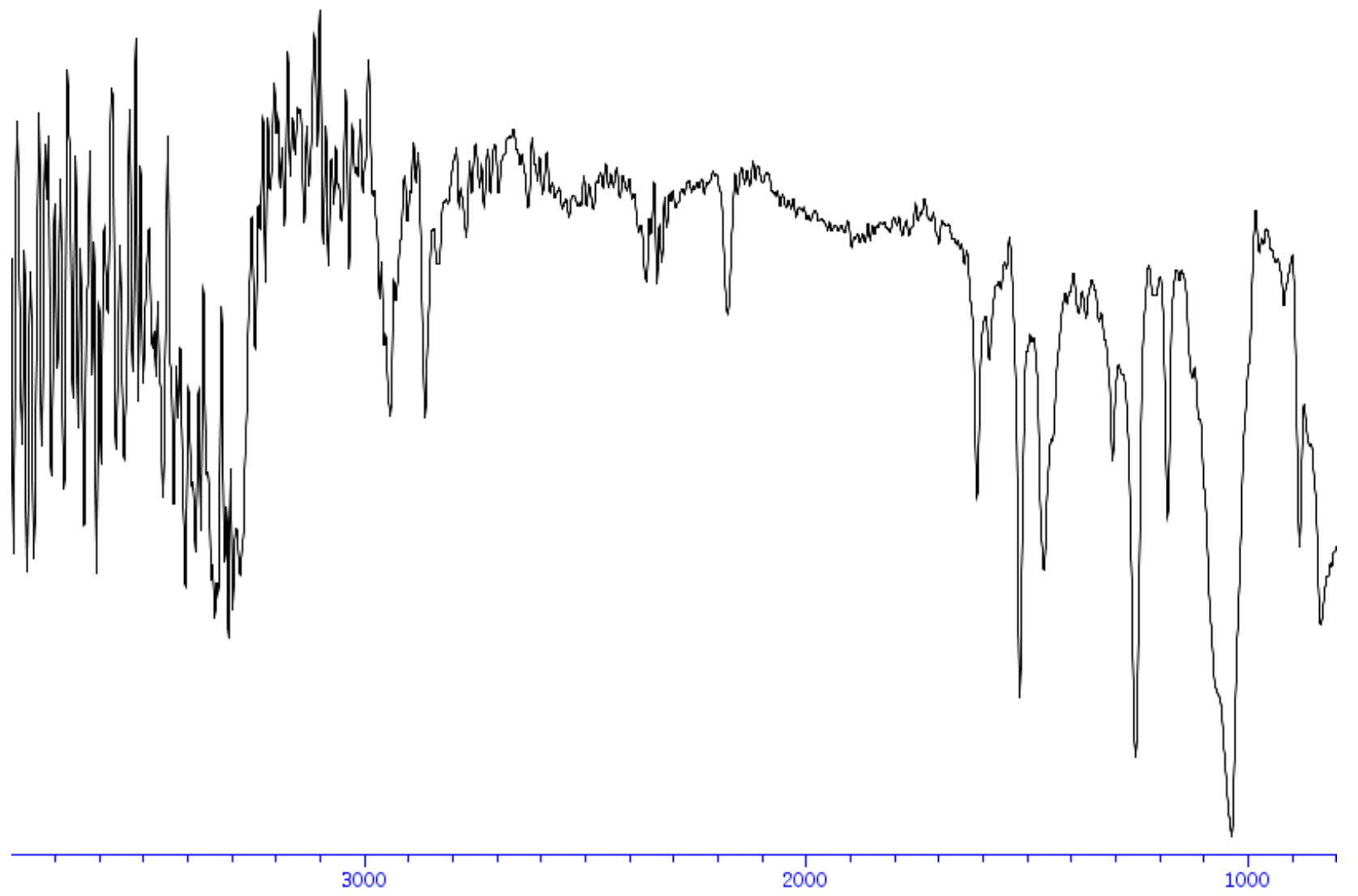




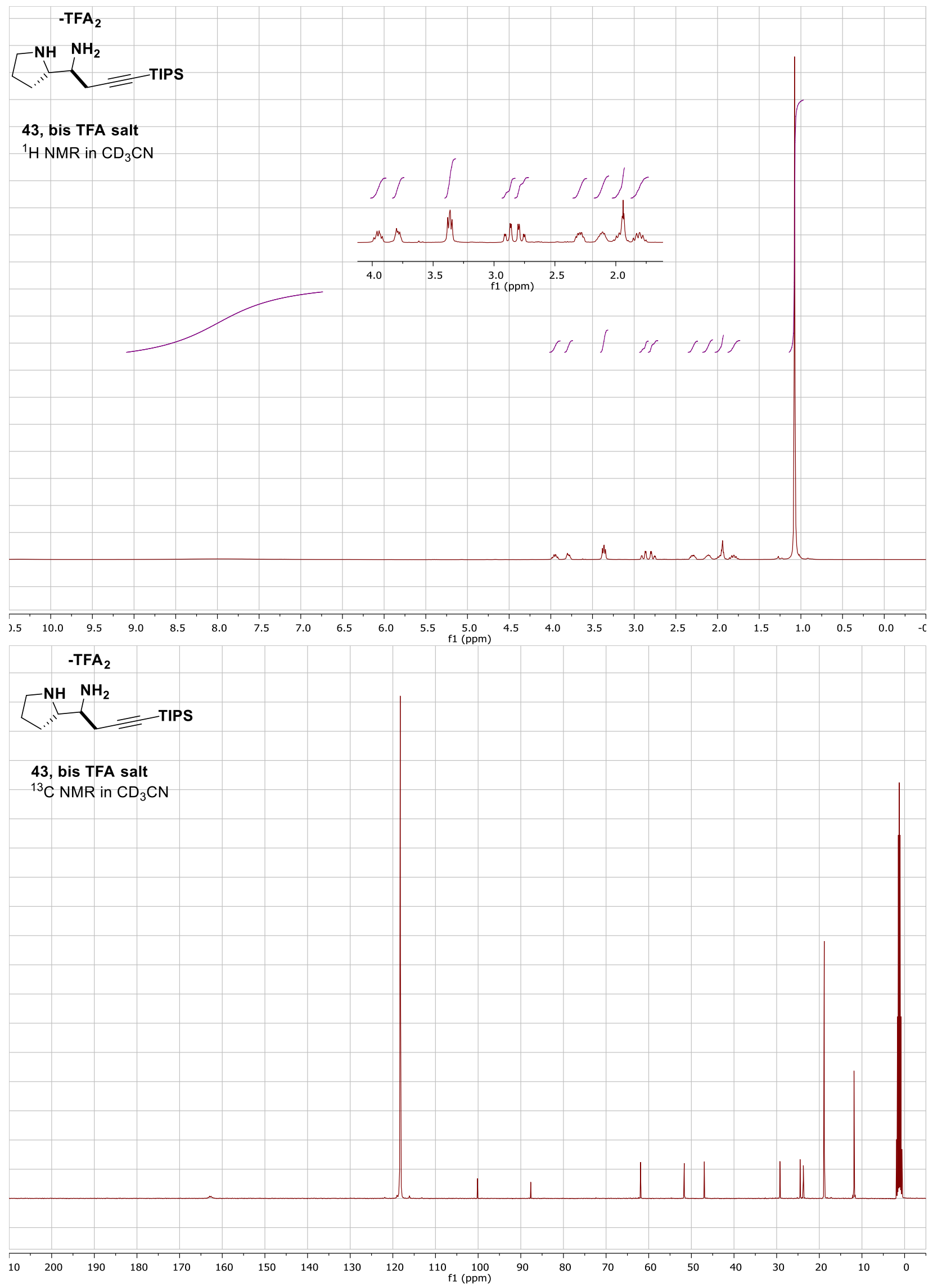




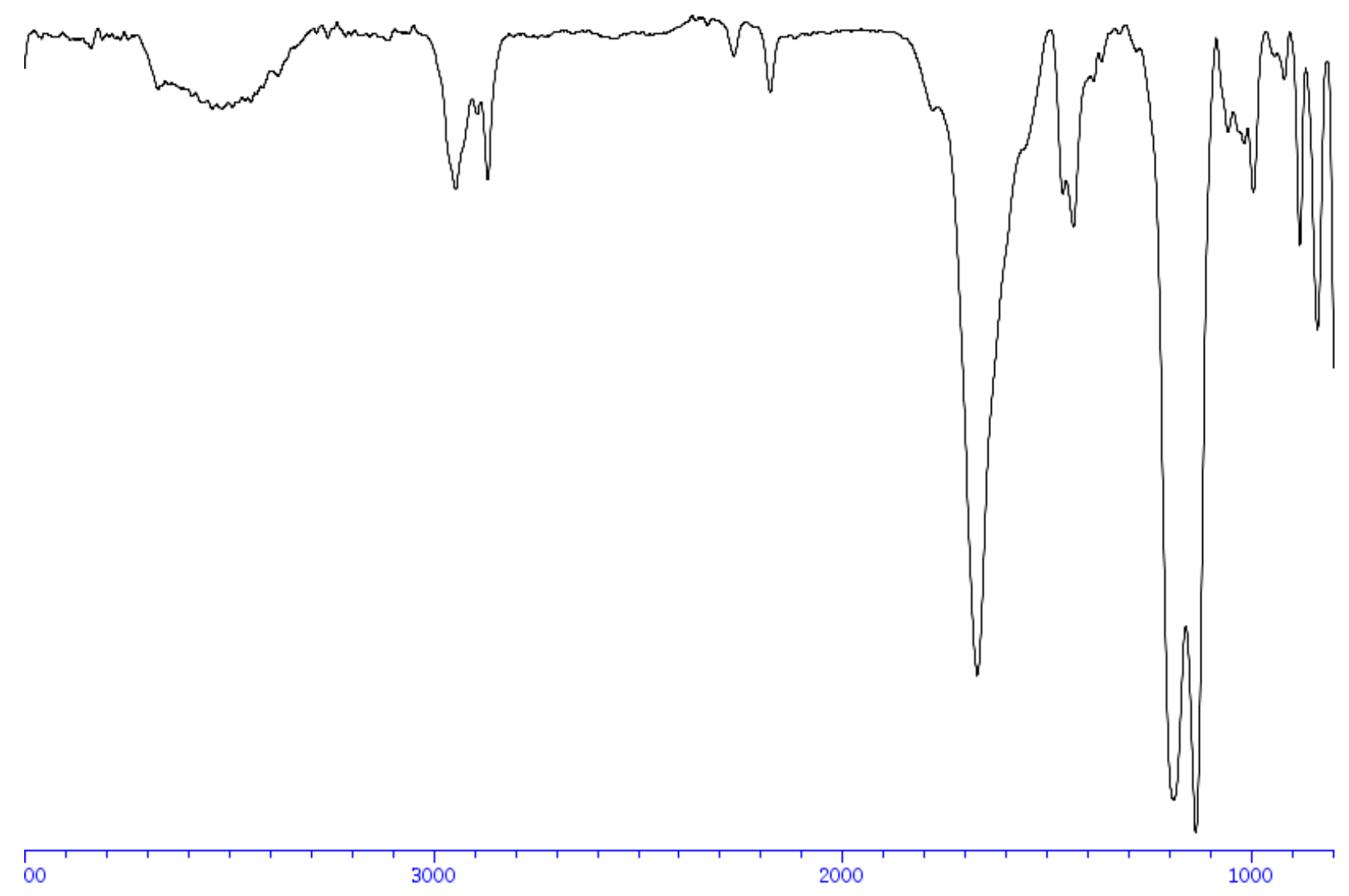




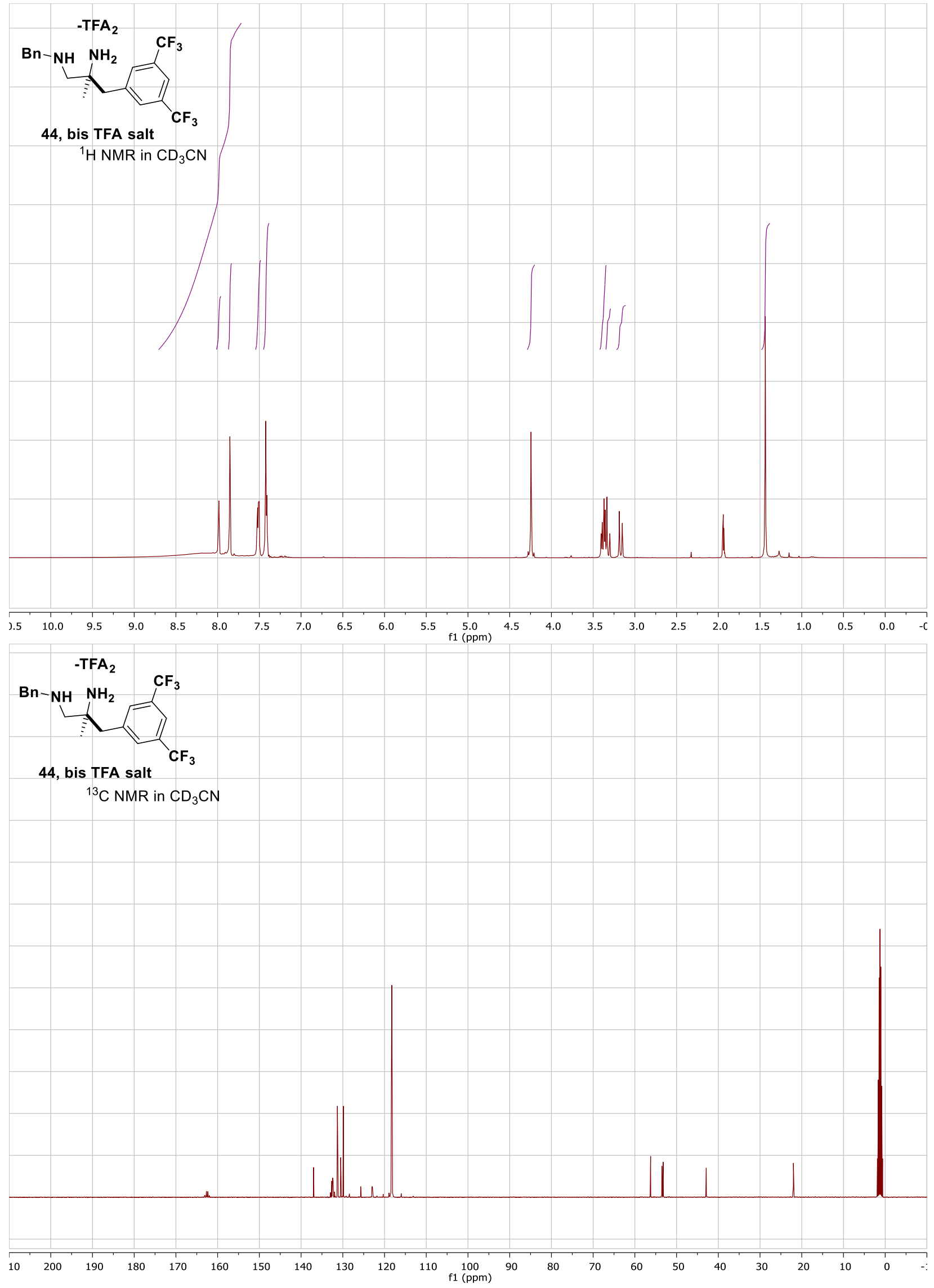




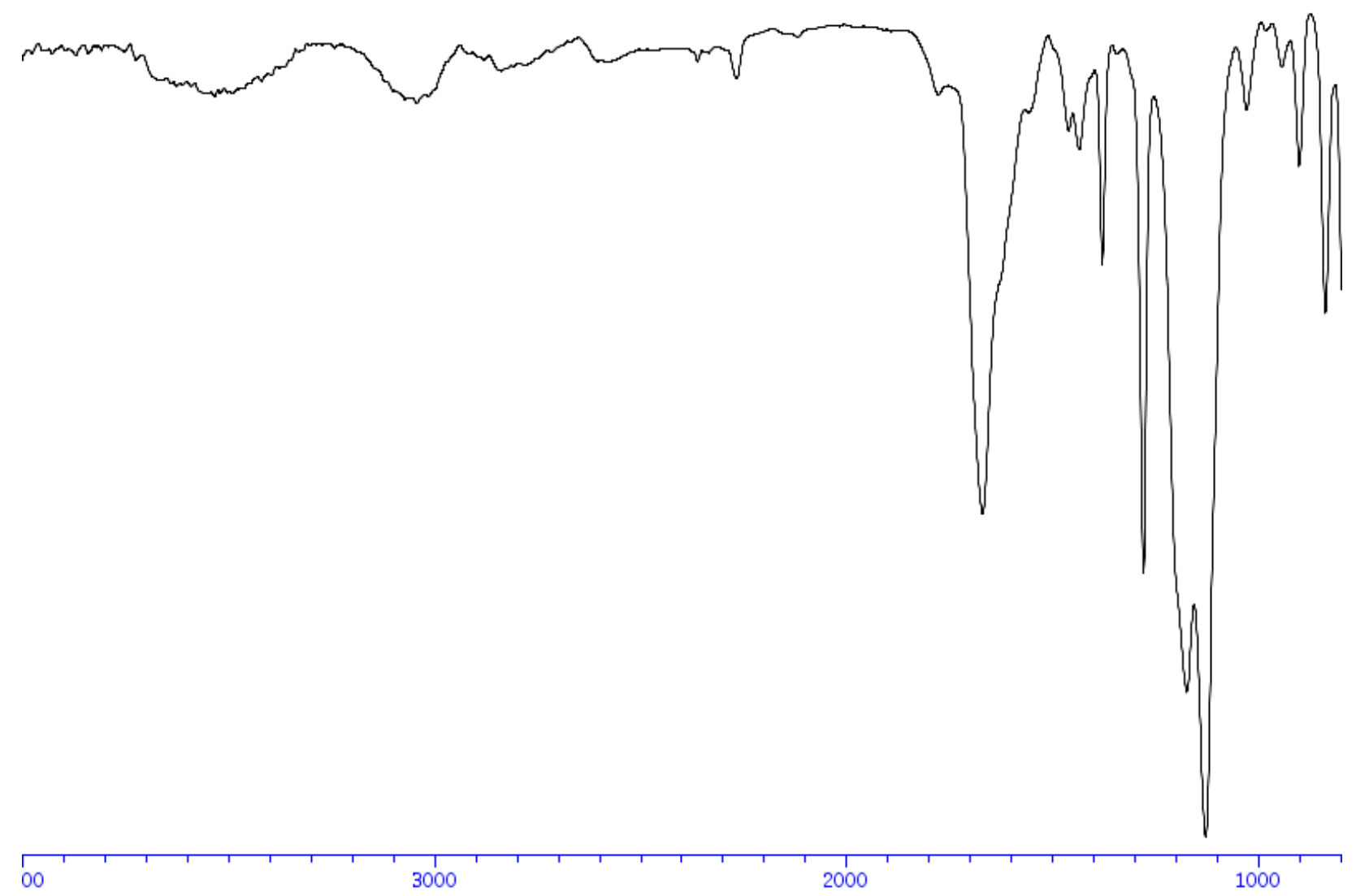

